\title{
A MINA DE COBRE DE CAMAQUÃ, RIO GRANDE DO SUL
}




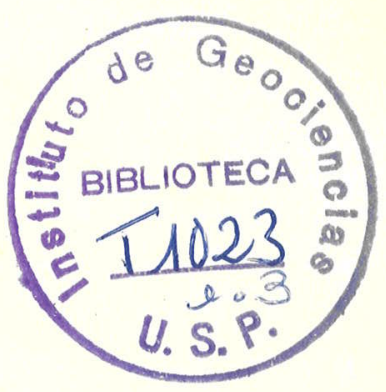

DEDALUS - Acervo - IGC

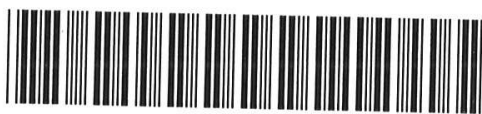

30900004635

\section{A MINA DE COBRE DE CAMAQUÃ, RIO GRANDE DO SUL}

$$
\text { Jorge ine hea eans }
$$

Tese de doutoramento apresentada ao Instituto de Geociências da Universidade de São Paulo

$$
1 G-14
$$


I RESUMO

II INTRODUÇÃO

III TRABALHOS ANTERIORES

IV PRODUÇÃO, RESERVAS E METTODOS DE LAVRA 10

IV. 1

Produçāo

IV. 2

Reservas

IV. 3

Lavra

V METODOLOGTA

VI EVOLUÇÃO DOS CONCEITOS GEOLÓGICOS REGIONAIS 20

VII ESTRATIGRAFIA E LITOLOGIA DA REGIÃO DE CAMAQUÃ 25

VII. 1

Generalidades

VII. 2

Grupo Bom Jardim

VII. 2. 1

Formação Arroio dos Nobres

VII. 2.1.1

Membro Mangueirão

VII. 2.1.2

Membro Vargas

VII. 3

Grupo Camaquã

VII. 3.1

Formação Santa Bárbara

VII. 3. 1. 1

Membro Rodeio Velho

VII. 3. 2

Formação Guaritas

VII. 4

Caracterização Local das Litologias

VII. 4.1

Generalidades

VII. 4. 2

Membro Mangueirão

VII. 4.2.1

Arenitos

VII.4.2.2

Ritmitos 
VII. 4.3

Membro Vargas

VII. 4.3.1

Arenito Inferior

35

VII. 4. 3.2

Conglomerado Vargas

VII. 4.3 .3

Arenito Médio e Arenitos Intercalados

VII. 4.3 .4

Arenito Superior

VII. 4.4

Diabásio

VIII TECTÔNICA

VIII. 1

Análise Estrutural

VIII. 1. 1

Procedimento de Campo e Tratamento dos Dados

VIII. 1.1.1

Mina S. Luiz

55

VIII. 1. 1.1.1

Falhas Maiores e Menores

VIII. 1. 1. 1.2

Juntas

56

VIII. 1.1.1.3

Acamamento

VIII. 1. 1.2

Mina Uruguai

VIIII. 1. 1.2, 1

Falhas Maiores e Menores

VIII. 1. 1.2.2

Juntas

VIII. 1. 1.2.3

Acamamento

VIII. 1. 1. 3

Superfície

VIIII. 1. 1.3.1

Falhas Principais e Menores

VIIT.1.1.3.2 Juntas

VIII. 1. 1.3.3

Acamamento

VIII. 1. 2

Relações Entre Falhas Maiores, Menores e Juntas

VIII. 1.3

Qualificaçāo das Fraturas

VIII. 1.4

Análise Dinâmica

68

VIII. 1.5

Estruturas Locais e Suas Relações Com os Sistemas Regionais 
IX VEIOS E MINERALTZAÇÃO

X CONTROLES DE IMINERALIZAÇÃO

X. 1

Generalidades

X. 2

Controles Estruturais

X. 2.1

Intersecções de Fraturas

79

X. 2.2

Estruturas Penadas

79

X. 2.3

Falhas Menores

X. 2.4

Caracteres Físicos das Rochas Encaixantes

80

X. 2.5

Irregularidades dos Planos da Falhas

80

X. 2.6

Movimento Intra-minério

81

X. 2.7

Zonas de Brechas

81

X. 3

Controles Estratigráfico e Litológico

82

XI CORPOS DE MINÉRIO

XI. 1

Generalidades

XI. 2

Mina S. Luiz

86

XI. 2.1

Zona Sul do Diabásio

XI. 2, 1.1

Filão 1 (Filão S. Luiz ou Principal)

86

XI. 2.1.2

Filão 2 (Filão Lapa)

XI. 2.1.3

Filão 3 (Filão Capa)

XI. 2.2

Zona Norte do Diabásio

XI. 2. 2. 1

Filão 4 (Filão Principal)

XI. 2.2.2

Filão 5 (Filão Lapa)

XI. 2.2. 3

Filão 6 (Filão Capa)

XI. 2. 3

Outros Filöes

XI. 2.4

Correlações

XI. 3

Mina Uruguai

XI. 3.1

Zona Uruguai 
XI. 3.1.1

XI.3.1.2

XI. 3.1.3

XI. 3.1.4

XI. 3.2

XI. 3.2.1

XI. 3.2.2

XI. 3.2. 3
Filão 1 (Filão Lapa)

Filão 2 (Filão Sôbre Lapa)

Filões $16,17,18$ e 19

Filão 3 (Filão Capa)

Zona Piritas

Filão 10 (Filão Piritas) e Filão 11

Filão 12

Outros Filöes
97

98

100

100

102

102

102

104

105

Pirita

105

Calcopirita

108

Bornita

110

Hematita

111

Calcosita

114

Quartzo

116

Clorita

118

Barita

119

Calcita

Limonita

120

120

Cuprita

121

Cobre Nativo

122

Malaquita

122

Crisocola

123

123

Covelita

XIII PARAGÊNESE

XIV, ALTERAÇÃO HIDROTERMAL E ZONAMENTO 140

XV OXIDAÇÃO E ENRIQUECIMENTO SUPÉRGENO 142

XVI ELEMENTOS MAIORES E MENORES $\quad 145$ 
XVI. 1

Generalidades

145

XVI. 2

Distribuição dos Elementos Traço

146

XVI. 3 Conclusões

XVII ORIGEM DA MINERALIZAÇÃO PRIMÁRIA

XVIII CONCLUSÕES

XIX AGRADECIMENTOS

XX BIBLIOGRAFIA 
1. Produção de Cobre da Mina do Camaquã de 1901 a 1972

2. Reservas da Mina de Camaquã

3. Sequências Estratigráficas da Região de Caçapava do SulLavras do Sul

4. Composição Modal de Arenitos do Membro Mangueirão

5. Análise Modal de Arenitos do Arenito Inferior

6. Composição Modal do Conglomerado da Mina de Camaquã 7. Composição Modal de Arenitos Intercalados aos Conglome-
rados

8. Análise Modal dos Arenitos do Arenito Superior

9. Composição Modal do Dique de Diabásio da Mina S. Luiz

10. Idades K-Ar do Dique de Diabásio da Mina S. Luiz

11. Paragênese Mineral na Mina de Camaquä

12. S, Fe, Cu, Co, Ni e Razão Co/Ni em Piritas e Calcopiritas

13. Ag, Pb, Cr, As, Zn, Co, Ni e Razão Co/Ni em Piritas e Calcopiritas

14. $\mathrm{Ag}, \mathrm{Pb}, \mathrm{Cr}, \mathrm{As}, \mathrm{Zn}, \mathrm{Co}$ e $\mathrm{Ni}$ em Hematita

15. $\mathrm{Pb}, \mathrm{Zn}, \mathrm{Cu}, \mathrm{Ni}, \mathrm{Co}$ e $\mathrm{Cr}$ em Andesitos e Granitos

16. $\mathrm{Ag}, \mathrm{Pb}, \mathrm{Cr}, \mathrm{As}, \mathrm{Zn}, \mathrm{Co}, \mathrm{Ni}$ e $\mathrm{Cu}$ em Concentrados

17. Análise Estatística 
1. Vista Parcial do Distrito Cuprífero de Camaquã 15

2. Instalações do Poço Principal 16

3. Feições da Lavra Céu Aberto na Zona Intermediária 16

4. Estratificação Gradual em Siltito do Membro Mangueirão 50

5. Estratificaçāo Gradual em Sedimentos Rítmicos do $\begin{array}{ll}\text { Membro Vargas } & 50\end{array}$

6. Grauvacas do Membro Mangueirão 51

7. Siltito do Membro Mangueirão 51

8. Arenitos Sublíticos Ferruginosos do Arenito Superior 52

9. "Wackes Arcósicos" 52

10. Pirita Cataclasada e substituida por Calcosita 125

11. Substituição de Pirita por Bornita 125

12. Textura Reticulada em Pirita 126

13. Calcosita Substituindo Bornita 126

$\begin{array}{lr}\text { 14. Calcopirita envolvendo Pirita } & 127\end{array}$

15. Substituição da Bornita por Calcopirita II $\quad 127$

16. Substituição da Bornita por Calcopirita II $\quad 128$

$\begin{array}{ll}\text { 17. Textura Mirmequítica } & 128\end{array}$

18. Cristais de Hematita 129

19. Hematitas em Rede Angular $\quad 129$

20. Textura Fluidal Formada por Hematita 130

21. Arranjo Concêntrico de Lamelas de Hematita Especular 130

22. Hematita Substituindo Fragmentos de Rochas 131

23. Substituição de Fragmentos de Rocha por Hematita Especular 131 
24. Cobre Nativo em Calcosita

25. Substituição de Hematita por Calcopirita II

26. Calcopirita II Substituindo Fragmentos de Minério

27. Calcopirita II Substituindo Hematita e Bornita

28. Calcosita Substituida por Bornita

29. Intercrescimento Mirmequítico

30. Intercrescimento Mirmequítico

31. Covelita Substituindo Calcosita

1. Mapa de Localização do Distrito da Mina de Camaquã

2. Folha Geológica da Mina de Camaquã

3. Mapa Geológico do Distrito Cuprífero da Mina de Camaquã

4. Diagramas de Contorno de Polos das Normais a Falhas da Mina S. Luiz

5. Diagramas de Contornos de Polos das Normais a Falhas da Mina Uruguai

6. Diagramas de Contornos de Polos das Normais a Falhas da Superfície

7. Diagramas de Contornos de Polos das Normais a Juntas Medidas à Superfície, Mina S. Luiz e Uruguai

8. Diagramas de Contornos de Polos das Normais a Acama mentos Medidos à Superfície e minas S. Luiz e Uruguai -

9. Diagrama Síntese de Polos de Normais a Falhas Principais da Mina de Camaquã 
10. Diagramas de Contorno de Polos das Normais a Falhas Principais das Minas S. Luiz e Uruguai com Projeçōes das Estrias de Falhas Correspondentes.

11. Configuração das Relaçöes Existentes Entre Fraturas e Direções de Esforços na Mina de Camaquã.

12. Diagrama de Contorno de Polos das Normais a Fraturas Pós - Mineralização.

13. Perfil Longitudinal ao Longo da Linha Base NW-SE- Mina Uruguai.

24. Conteudo de Co e Ni em Piritas da Mina de Camaquã.

25. Conteudo de Co e Ni em Calcopiritas da Mina de Camaquã.

\section{ANEXOS}

3. Mapa Geológico do Distrito Cuprífero da Mina de Camaquã.

14 Padrão Estrutural e'Mineralização - Mina S. Luiz.

15 Padrão Estrutural e Mineralização - Mina Uruguai.

16. Controles de Mineralização das Minas S. Luiz e Uruguai.

17 Controles de Mineralização das Minas S. Luiz e Uruguai.

18 Controles de Mineralização das Minas S. Luiz e Uruguai.

19 Controles de Mineralização das Minas S. Luiz e Uruguai.

20 Mina S. Luiz - Plantas de Níveis

21 Mina Uruguai - Plantas de Níveis.

22 Mina S. Luiz - Realces e Perfis Transversais.

23 Mina Uruguai - Realces e Perfis Transversais. 
A Mina de cobre de Camaquã, no Estado do Rio Grande do Sul, é cons tituída por duas zonas principais, denominadas, Mina S. Luiz e Mina Uruguai, além dos setores subsidiários conhecidos por Zonas Interme diária, Potreiros, Oscarino, Feliciano e Cêrro das Tunas. Pequenos filões, de menor importância também são assinalados (Fig. 3 ).

O setor S. Luiz se compõe da mina propriamente dita e de vários filões isolados, conhecidos como, São Júlio, Barnabé e Esperança. Sem con siderar os filões isolados, abrange uma faixa de aproximadamente 700 metros de comprimento, com largura variável, de 20 metros na extre midade SE e 110 metros no extremo NW. Seus filöes mais importantes, modernamente foram designados como Principal ou S. Luiz, Capa e Lapa.

Na Mina Uruguai, sempre se considerou a existência de duas zonas independentes, quais sejam, Zona Uruguai e Zona Piritas, separadas pela Falha Piritas. Os veios ocorrem numa área com extensão de 650 metros de larguras de 270 metros na Zona Piritas e 180 metros na Zona Uruguai. Os veios mais importantes são: Filão Piritas, na Zona Piritas; filões, Lapa, Sôbre Lapa, Capa e Sôbre Capa na Zona Uruguai.

Os trabalhos de lavra e pesquisa, efetuados nos últimos 30 anos, permi tiram verificar a existência de um sistema de veios, muito mais numero sos do que acima indicado.

A Zona Intermediária, situada entre as minas S. Luiz e Uruguai, dista 300 metros da Zona Piritas e 200 metros da extremidade SE da Mina S. Luiz. Ao contrário das duas minas anteriores, esta zona se caracte riza por densos fraturamentos subsidiários a falhas principais.

A Zona Potreiros dá continuidade aos veios isolados da Mina S. Luiz; estende-se por cerca de 700 metros, com largura aproximada de 200 metros. Nesta faixa ocorrem inúmeros veios, predominantemente constituídos por minerais de ganga. 
Os setores Cêrro das Tunas e Feliciano possuem vários filões contí nuos, além de afloramentos isolados, cujos comprimentos variam de poucos até 120 metros; podem ser considerados como prolongamentos das falhas mineralizadas da Zona Piritas.

Todos os setores da Jazida de Camaquã foram pesquisados em diversas épocas, por trincheiras superficiais e por galerias, trabalhos de sonda gem e desenvolvimento subterrâneo. Os setores Oscarino, Feliciano, Cêrro das Tunas e Potreiros a despeito dos intensos trabalhos de pesquisa efetuados, apresentam inexpressiva reserva de minério. Em contrapartida, as Minas S. Lui.z, Uruguai e Zona Intermediária mos tram-se possuidoras das maiores reservas de minério de cobre no distrito sendo responsáveis por toda a produção da jazida de Camaquã.

As rochas mais abundantes no distrito, pertencem aos Grupos Bom Jardim e Camaquã, respectivamente de idades pré-cambriana e paleo zóica inferior, além de diques de diabásio de idade mesozóica e sedi mentos recentes (Fig. 2 ). As unidades sedimentares possuem uma espessura local provávelmente de vários quilômetros e recobrem o embasamento pré-cambriano. O complexo sedimentar, representado pelos grupos acima discriminados, é constituido de arenitos, ritmitos, grauvacas e conglomerados, além de intrusivas e extrusivas andesíticas. O Grupo Bom Jardim, contendo as rochas mais antigas do distrito, é recoberto em discordância angular pelos sedimentos do Grupo Camaquã.

Em âmbito local, as rochas do Grupo Bom Jardim são mais importantes, uma vez que constituem as encaixantes da mineralização cuprífera. Emergem no núcleo de um anticlinal formado por rochas do Grupo Camaquã, determinando uma estrutura homoclinal, cujas camadas possuem direção NE e mergulho médio em torno de $35 \%$.

O dique de diabásio mais importante na área corta o sistema de veios da Mina S. Luiz, seccionando-a em duas zonas; dados geocronológicos apontam uma idade correspondente ao Cretáceo Médio Inferior. Meta morfismo termal, tanto dos sulfetos quanto das rochas encaixantes, é observado nos contatos deste corpo. 
As feições estruturais dominantes no distrito, são representadas por grandes falhamentos transcorrentes com direção NE, e falhas normais, tracionais e subsidiárias, com direção NW, todas de idade pré-cam briana. Estas últimas são transversais ou oblíquas à direção média das camadas e à estrutura homoclinal do Grupo Bom Jardim e assumem extrema importância pelo fato de estarem associadas à mine ralização no distrito. Falhamentos pós-mineralização também foram assinaldos, cortando as estruturas acima apontadas.

A distribuição dos depósitos filonares é restrita a arenitos, ritmitos e conglomerados dos Membros Mangueirão e Vargas que são unidades da Formação Arroio dos Nobres do Grupo Bom Jardim (Fig. 3 ). Verificou-se que, em geral, a mineralização econômica é principal mente localizada nos conglomerados e arenitos conglomeráticos; entretanto, mineralizaçōes de porte foram constatadas em arenito, a grande profundidade, com condicionamento tectónico discutido no capí tulo $X$.

Os depósitos filonares se formaram por preenchimento e substituição ao longo de planos de falhas normais e estruturas penadas associadas; há também mineralização disseminada nas paredes e nos espaços entre os planos de falhas. A possança dos filöes varia de poucos centímetros a um máximo de 4 metros, nas zonas de enriquecimento. A persistência dos principais corpos de minérios em profundidade é notória, até pelo menos 330 metros na vertical, não havendo evidências, de que o limite inferior de mineralização tenha sido atingido em qualquer localidade. De um modo geral, os filões principais das minas Uruguai e S. Luiz tem mergulhos para SW e NE, respectivamente, sendo possível prever os caimentos dos corpos mineralizados, em função das estruturas e estratigrafia.

Os tipos de alteração das encaixantes identificados no distrito são: silicificação, caolinização e sericitização, que acompanham, com mais frequência a mineralização primária. Digna de nota, é a cloritização intensa, desenvolvida na Mina Uruguai, particularmente na Zona Piritas. Representa uma alteração tardia, superimposta à alteração primitiva e acompanha a mineralização hematítica. 
De uma maneira geral, a sequência paragenética indica a existência de pelo menos, quatro fases de deposição. As soluções mineralizantes sofreram modificações físico-químicas marcantes, durante a evolução do depósito sendo funçäo dos eventos magmático-tectônicos coevos. A paragenese primária é simples, sendo os principais sulfetos e óxidos: pirita, calcopirita, bornita, hematita e calcosita.

Zonamento vertical hipógeno, em veios, foi observado, especialmente na Mina S. Luiz onde a lavra já atingiu o nível 700 pés. Notou-se que a calcopirita e pirita aumentam em profundidade, predominando nos níveis 600 e 700 pés. Na Mina Uruguai, mesmo no nível 500 pés, há sempre mistura intensa de minerais hipógenos e supérgenos. Ligeiro zonamento lateral primário foi notado na Zona Piritas da Mina Uruguai, onde predomina mineralização a hematita.

A Jazida de Camaquã apresenta todas as características de depósitos hidrotermais mesotermais. A julgar pelos dados geoquímicos obtidos, as soluções hidrotermais sulfuretadas são consideradas derivadas de uma fonte magmática profunda.

Os condutos primários seriam, provavelmente, as grandes falhas de direção NE, que atingiriam o embasamento cristalino. Devido ao ambien te tectônico propício da Zona da Mina, as soluçōes seriam canalizadas, secundariamente, para as falhas NW, com espaços abertos adequados à deposição de sulfetos, óxidos e minerais de ganga. As rochas encai xantes teriam um papel relevante no fornecimento dos elementos neces sários à formação de grande parte dos minerais de minério e ganga.

Lixiviação e enriquecimento supérgeno são bem desenvolvidos no dis trito, com formação de calcosita e bornita como minerais principais. A fixação precisa dos limites da zona enriquecida é problemática, devido às dificuldades em discriminar a natureza hipógena e supérgena da calcosita e bornita, bem como pela oxidação intensa, efetuada em realces antigos e galerias dos níveis inferiores, por águas percolantes. 
O distrito mineral da Mina de Camaquã situa-se no Município de Caça pava do Sul, Estado do Rio Grande do Sul. Faz parte do chamado "Po lígono Cuprífero Riograndense", definido por Ribeiro et al (1966 pg. 171), que abrange a área delimitada pelas ocorrências cupríferas na Quadrícula de Caçapava do Sul, estendendo-se, ainda, por algumas dezenas de quilômetros para Sudoeste dentro da Quadrícula de Pinhei ro Machado, nos Municípios de Bagé e Pinheiro Machado (Fig. 1 ).

As atividades de prospecção e lavra de cobre e ouro neste distrito foram historiadas por Teixeira (1937, 1941), Oliveira (1944), Costa Filho (1944), Leonardos (1944) e, detalhados extensamente, por Gavronski (1965 e 1971), sem dúvida, o melhor conhecedor de todo o Polígono. Êste distrito começou a ter notoriedade após a descoberta, em 1865 - 70, das primeiras amostras de minério de cobre oxidado, na área da Mina de Camaquã, então Campos de João Dias dos Santos.

As atividades de prospecção e princípio de lavra tiveram início em 1888 , embora a produção efetiva tenha começado e se estendido no período compreendido entre 1900 e 1908, pela "Societé Anonyme des Mines de Cuivre du Camaquã". Os primeiros trabalhos mineiros no distrito fo ram conduzidos por inglêses e belgas, estes da "Societé Anonyme des Mines de Cuivre du Camaquã. Um reinício efêmero de lavra foi assina lado no ano de 1944, mas somente no período compreendido entre $195 \overline{2}$ e 1955 se efetuou a retomada e implantação definitiva da lavra, pela Companhia Brasileira do Cobre (C.B.C), detentora da Mina de Camaquá desde 1942 .

Em âmbito regional, numerosos trabalhos foram publicados versando sôbre os mais diferentes aspectos geológicos. Restritas ao distrito, as únicas publicações mais recentes e que abordam problemas mineiros e geológicos são de autoria de Costa Filho (1944), Leinz e Almeida (194J.) e Ribeiro et al (1966). De 1946 até a presente data, a lavra subterrânea foi extremamente intensificada. Trabalhos detalhados de pesquisa foram 
efetuados desde 1958, particularmente sondagens e mapeamentos de subsolo. O volume de observações geológicas coletadas nos últimos 3 anos modificam substancialmente e complementam muitas observa ções anteriormente feitas. Por outro lado, os trabalhos geológicos regionais e de detalhe, efetuados à escala 1:250.000 e 1:50.000 consti tuem apoio seguro a qualquer tentativa de síntese.

O autor integrou, a partir de meados de 1969 até janeiro de 1971, o grupo técnico de pesquisa da C.B.C. operando na Mina de Camaquã. Durante êsse período, essa equipe coletou um volume considerável de dados geológicos, que se revelam de grande importância para o conhe cimento estrutural e metalogenético do distrito. Os resultados obtidos e as excelentes informações geológicas regionais, atualmente disponí veis, possibilitaram ao autor, esboçar uma análise geológica em esca la de distrito, visando os seguintes objetivos principais: 1) execução de análise tectônica do distrito, com caracterização das fraturas prémineralização e dos esforços responsáveis pelas deformações na área, 2) estabelecimento dos fatores responsáveis pela localização do miné rio, 3) análise tridimensional dos principais corpos de minério, visan do melhor visualização do comportamento em profundidade, 4) estudo da mineralogia do minério, com suficiente detalhe para o estabeleci mento das fases de mineralização e da sequência paragenética perti nente, 5) estudo das concentrações e distribuição dos elementos traço e menores, nos principais sulfetos, testando a aplicabilidade das relações mútuas entre esses elementos, visando esclarecer alguns pro blemas ligados à gênese dos veios hidrotermais no distrito.

A análise tectônica e o estudo dos elementos traço devem ser encara dos como experiências pioneiras, sujeitas a complementações futuras. Vários outros aspectos de importância para o distrito deixaram de ser tratados em detalhe, pois demandariam estudos adicionais de campo e laboratório. Detalhamento da alteração hidrotermal no distrito, deter minações isotópicas e análises mais numerosas de elementos traço para complementar os dados já existentes e permitir conclusões gené ticas seguras, não puderam ser realizadas no momento. Trabalhos 
adicionais de levantamento geológico superficial detalhado, especial mente no setor da Mina Uruguai, permitiriam o entendimento tridi mensional de inúmeros corpos de minério, imperfeitamente conhecidos na capa do depósito.

Para a compilação das informações geológicas superficiais e localiza ção dos filões, foram utilizados mapas plano-altimétricos às escalas 1:5.000, 1:1.000 e 1:500. Nos trabalhos de mapeamento geológico de subsolo, em galerias e realces, foram necessários mapas plani métricos à escala 1:250, todos executados pela equipe técnica da C.B.C.

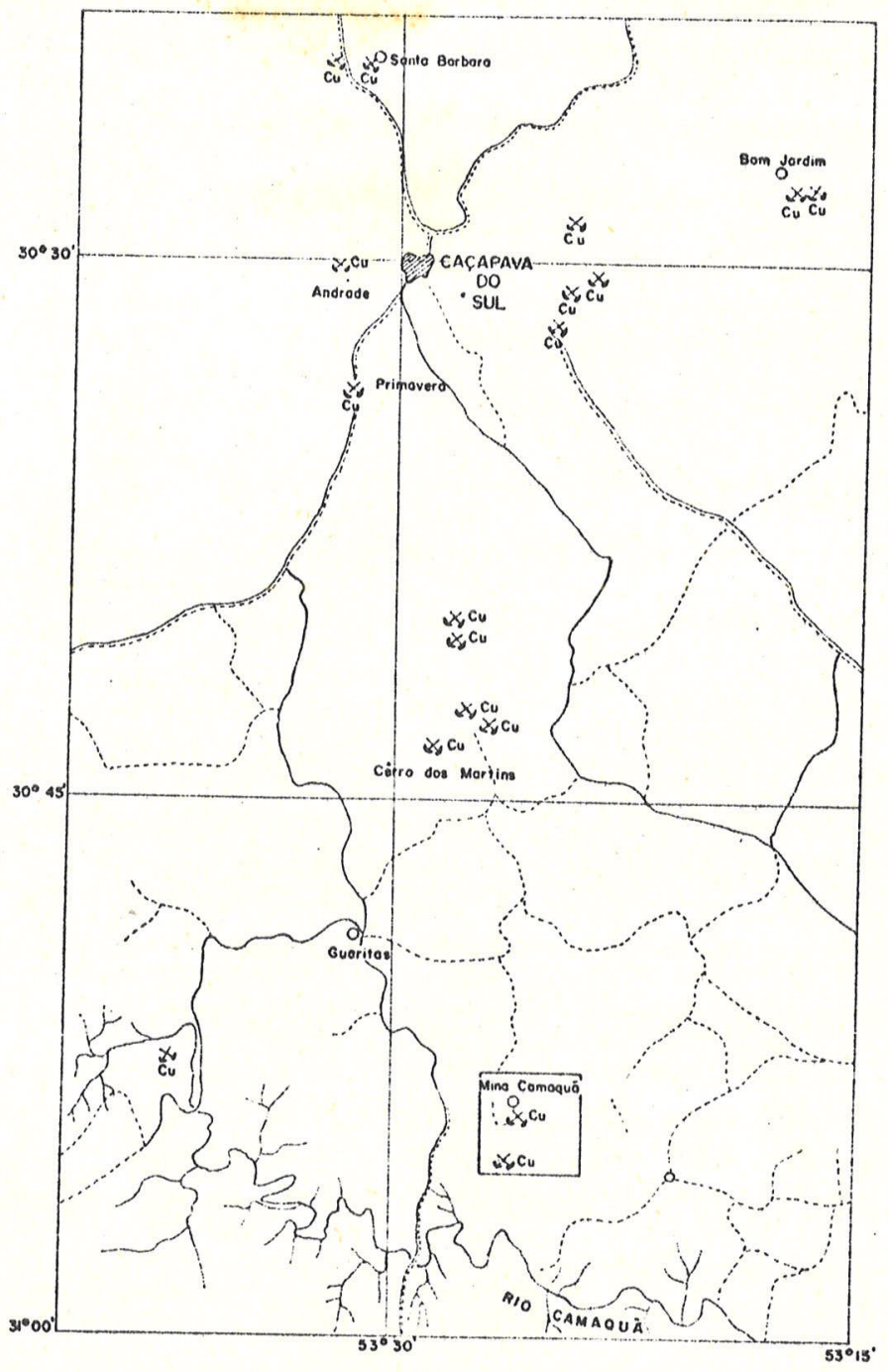

MAPA DE LOCALIZACĀO DO DISTRITO DA MINA DE CAMAQUÄ

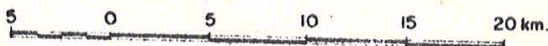

Localizǫ̧̋o Geografica do Mina do Carnoquä

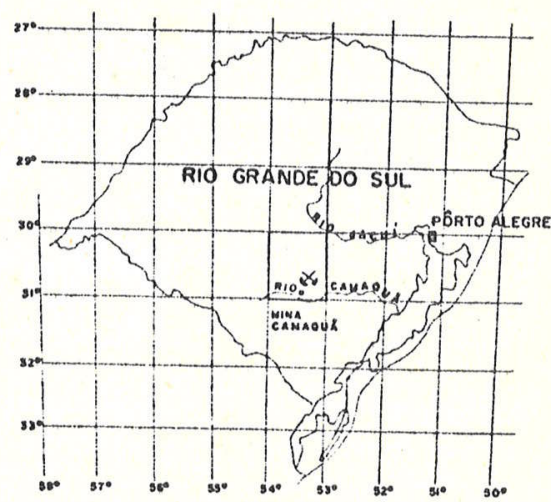

Fig.-7 
Os primeiros trabalhos mineiros no distrito foram conduzidos em 1888, por agricultores alemães de Pelotas e posteriormente por in gleses e belgas, estes da "Societé Anonyme des Mines de Cuivre du Camaquã". As primeiras descrições de ocorrências são de autoria de Carvalho (1932) e Teixeira (1937). A pesquisa sistemática em caráter preliminar, para avaliação das possibilidades do distrito, teve início com Emílio Alves Teixeira, que resumiu os resultados em 1941. Estes trabalhos tiveram como objetivos a desobstrução de acessos e galerias, confecção de mapas topo-geológicos de superfície e subsuperfície, amostragem dos veios e realces antigos, descrição dos filóes e da geologia, bem como o estabelecimento de uma sequência estratigráfica local. Esta campanha se prolongou até 1944 e contou com numerosa equipe de engenheiros de minas e geólogos. Merece destaque a impor tante contribuição de Leinz e Almeida (1941), que apresentaram um estudo detalhado da mineralogia, paragênese e origem do minério, único até a presente data. Costa Filho (1944) teve o mérito de não só compilar todos os dados de pesquisa geológica efetuada pelas equipes anteriores, como também acrescentar informações importantes de cunho pessoal. Esta obra minuciosa, ainda hoje, é ótimo guia para lavra das porções de minério existentes acima do nível 300 pés da Mina São Luiz.

Entre 1957 e 1961, merecem destaque as atividades da equipe "Comis são Mista de Investigação dos Recursos de Metais não Ferrosos", cons tituida pela Comissão Mista Departamento Nacional de Produção Mineral e United States Geological Survey . As contribuições de Melcher (1957, 1959, 1962), Melcher e Mau (1960), Martinelli e Nogueira Filho (1959), Robertson (1961, segundo Ribeiro et al 1966), atestam a inten sa atividade do período, compreendendo levantamento geológico de su perfície, à escala 1:1.000, testes de aplicabilidade de prospecção geo química, além de levantamento e amostragem de subsolo, na Mina S. Luiz. 
Os trabalhos da "Comissão Mista", no período compreendido entre 1958 e 1961, desenvolveram-se paralelamente à pesquisa executada pelo D.N.P. M. - Rio Grande do Sul, em regime de cooperação com a C.B.C., sendo esta representada pelo grupo Japonês "Mitsubishi Metal Mining Company", na época responsável pela operação da Mina.

Estas pesquisas possibilitaram a abertura de uma nova mina, no setor Filão Piritas - Mina Uruguai, o aprofundamento dos níveis 400 e 500 pés da Mina S. Luiz, além de evidenciar minério até ao nível 900 pés.

A partir de 1969, a C.B.C. iniciou um projeto de ampliação das insta lações de concentração de minério, com a construção de uma usina com capacidade de 70 mil toneladas mensais de minério. Para atender a este desenvolvimento e definir reservas que permitissem essa pro dução, a C.B.C. elaborou programa de sondagens profundas, visando testar a continuidade da mineralização até ao nível 1.100 pés, nas duas Minas (S. Luiz e Uruguai). Este programa foi elaborado pela equipe de técnicos da C.B: C. , ficando a execução dos furos de sondagem a cargo do D.N.P.M. - R.G.S., em regime de cooperação. Paralelamen te ao programa de desenvolvimento, foram iniciados, em 1969, pela primeira vez na Mina, trabalhos de mapeamento geológico sistemático no subsolo, à escala 1:250.

Dando continuidade ao programa de pesquisa, Ellert (1971) executou um levantamento geofísico no distrito, tendo como finalidade a observa ção da aplicabilidade do método eletromagnético indutivo, nos tipos de jazimento e condições superficiais da área. Foram utilizados os equi pamentos E.M. Sharpe (Canadense) e E.M.Gun (Sueco), efetuando-se perfís perpendiculares às estruturas locais, em extensão superior a 25 quilômetros.

Em 1970 foi criada a Companhia de Pesquisa e Recursos Minerais (C.P.R.M.), que sucedeu ao D.N.P.M. na execução do programa de sondagem profunda, ainda em curso, mediante contrato de prestação de serviços com a C.B.C. 


\section{IV. $1 \quad$ Produção}

A quase totalidade da produção brasileira de cobre provém da Mina de Camaquã, repartida pelos setores Mina S. Luiz e Mina Uruguai, além de pequena contribuição do setor, Zona Intermediária. As pro duções do início do século eram totalmente exportadas constituindo de minério escolhido, minério concentrado e mate, com altos teores em cobre. A Tabela 1 apresenta uma estimativa da produção e dos teores obtidos durante a vida da Mina, configurando assim a evolu ção da produção até a presente data. Os dados numéricos resultam de uma compilação bibliográfica Oliveira (1944), Costa Filho (1944), de relatórios da C.B.C. e também de informações verbais. Basean do-se nesses valores, deduz-se que a produção total de cobre, até o momento, pode ser avaliada em aproximadamente 25.000 toneladas. O aumento da capacidade do Velho Engenho de Concentração de miné rio assim como melhorias operadas na lavra e transporte do minério, de 1967 a 1971, possibilitaram um aumento efetivo de minério des montado e concentrado. A conclusão das instalações do Poço Novo (Mina S. Luiz) em 1969 e do Novo Engenho em 1971, com capacidade para 70 mil toneladas mensais, permitiram duplicar a produção de minério nos anos 1971 e 1972 (Fot.1,2 e 3). 
TABELA 1

PRODTÇÃO DE COBRE DA MINA DE CAMAQUĀ DE $1901=1972$

\begin{tabular}{|c|c|c|c|c|c|c|}
\hline ANo & $\mid \begin{array}{c}\text { MINERIO } \\
\text { PRODUZIDO } \\
(t)\end{array}$ & $\begin{array}{c}\text { TEOR MÉDIO PONDERADO } \\
\text { DE MINÉRIO } \\
(\%) \\
\end{array}$ & $\underset{(t)}{\text { CONCENTRADO }}$ & $\begin{array}{c}\text { TEOR MÉDIO PONDERADO } \\
\text { DO CONCENTRADO } \\
(\%)\end{array}$ & & $\underset{(\mathrm{kg})}{\mathrm{COBRE}}$ \\
\hline 1901 & - & - & 478 & 30,0 & - & 143.400 \\
\hline 1902 & - & - & 235 & 30,0 & - & 70.500 \\
\hline 1903 & - & - & 795 & 28,5 & Minério escolhido & 226.570 \\
\hline 1904 & 1.933 & 6,4 & 556 & 23,0 & $\begin{array}{l}\text { Min concentrado } \\
\text { Minério bruto }\end{array}$ & $\begin{array}{r}127.880 \\
12.370\end{array}$ \\
\hline 1905 & - & - & 658 & 30,0 & - & 197.400 \\
\hline \multirow[t]{2}{*}{1906} & - & - & 720 & 30,0 & Minério & 216.000 \\
\hline & & - & 429 & 50,0 & Mate & 214.500 \\
\hline \multirow[t]{2}{*}{1907} & - & - & 607 & 30,0 & Minério escolhido & 182.100 \\
\hline & & & 255 & 50,00 & Mate & 127.500 \\
\hline 1908 & - & - & 818 & 30,0 & - & 245.400 \\
\hline 1956 & - & - & 300 & 32,0 & - & 96.000 \\
\hline 1957 & - & - & 300 & 32,0 & - & $96.00 n$ \\
\hline 1958 & - & - & 300 & 32,0 & - & 96.000 \\
\hline 1959 & - & - & 500 & 32,0 & - & 160.000 \\
\hline 1960 & - & - & 800 & 34,0 & - & 272.000 \\
\hline 1961 & - & - & 1.000 & 35,0 & - & 350.000 \\
\hline 1962 & - & - & 1.200 & 36,0 & - & 432.000 \\
\hline 1963 & - & - & 1.500 & 37,0 & - & 555.000 \\
\hline 1964 & - & - & 1.800 & 38,0 & - & 684.000 \\
\hline 1965 & - & - & 1.800 & 38,0 & - & 684.000 \\
\hline 1966 & 117.528 & 1,66 & 1.849 & 39,4 & - & 728.500 \\
\hline 1967 & 128.747 & 1,56 & 1.898 & 38,5 & - & 730.730 \\
\hline 1968 & 159.413 & 1,64 & 2.386 & 37,4 & - & 892.360 \\
\hline 1969 & 231.089 & 1,39 & 8.266 & 36,1 & - & 2.984 .400 \\
\hline 1970 & 306.171 & 1,20 & 10.022 & 33,7 & - & 3.337 .400 \\
\hline 1971 & 480.082 & 0,94 & 14.039 & 30,4 & - & 4. 267,800 \\
\hline \multirow[t]{2}{*}{1972} & 480.000 & 1,00 & 14.000 & 30,4 & - & 4.256 .000 \\
\hline & & & & & Total - & 22.385 .810 \\
\hline
\end{tabular}

OBS: a) Os dados anteriores a 1908 foram extraídos de Costa Filho (1944) e Oliveira (1944)

b) Os valores restantes foram obtidos da C. B.C. e de informaçóes pessoais. 
O levantamento das reservas de minério da Mina de Camaquã, foi efetuado por Bettencourt e Cornuth (1971). Esta cubagem foi feita até ao nível 1.100 pés, das Minas S. Luiz e Uruguai. Foi baseada em dados de sondagem existentes até dezembro de 1970, bem como nos trabalhos de desenvolvimento e serviços sistemáticos de mapea mento geológico e de subsolo, executados no período entre 1969 e 1972 , e que mais visam aproveitar as porções de minério abandonadas nos níveis superiores. À época da confecção do relatório de cubagem, estava em curso uma campanha de sondagem profunda nas minas Uruguai e S. Luiz, cujos resultados não foram utilizados nessa esti mativa. As informações obtidas dessa campanha de sondagem profunda, embora ainda em execução, demonstraram a existência de corpo de minério possante, abaixo do nível 1.100 pés da Mina Uruguai, no Arenito Inferior (Fig. 13), além de inúmeros filões localizados na região da capa da Mina Uruguai, não pesquisados anteriormente.

Os trabalhos de pesquisa, então, efetuados, permitiram uma reinter pretação do comportamento dos corpos de minério pela equipe técnica da C.B.C. e possibilitaram uma previsão, para a Mina Uruguai, até ao nível 1. 200 pés, de aproximadamente 9 a 10 milhões de toneladas de minério inferido, com teores em cobre variável entre 1, 0 a 1,5\%.

A Tabela 2 apresenta um resumo geral das reservas e seus respecti vos teores. Deve-se assinalar que os teores obtidos na cubagem de 1971 foram otimistas, pois os teores médios mensais da Mina se mostram sistematicamente bem inferiores aos teores de alimentaçäo do engenho. Este fato é atribuido à diluição na lavra, êrros sistemá ticos na amostragem efetuada antes de 1969 e à irregularidade da dis tribuição da mineralização. Presentemente, este problema está sendo resolvido em cada bloco de desmonte, pela equipe de produção da C. B.C., aplicando-se um fator de correção, estatısticamente determina do, ao teor médio obtido em cada bloco de desmonte e que deve variar em torno de 15 a $20 \%$. 
TABELA 2

RESERVA CA MINA DE CAMAQUÄ

RESUMO $Q E R A L$

(1971)

\begin{tabular}{|c|c|c|c|c|c|c|}
\hline \multirow{3}{*}{ MINA SAO LUIZ } & \multirow{2}{*}{ MEDIOA } & \multicolumn{2}{|c|}{$R E S F R V A$} & \multicolumn{2}{|l|}{$(t)$} & \multirow{2}{*}{$\begin{array}{l}\text { RESEFVA (t) } \\
\text { SUB-TOTAL }\end{array}$} \\
\hline & & INDICADA & INFERICA & PILAFES & DESMONTLDA & \\
\hline & $\begin{array}{c}17.871 \quad 1,29 \\
1.373 .377\end{array}$ & $\begin{array}{cc}11.763 & 1.32 \\
390.369\end{array}$ & $\begin{array}{cc}16.259 & 1.45 \\
1.125 .153 \\
\end{array}$ & $\begin{array}{c}2.202,1.38 \\
159.198\end{array}$ & $\begin{array}{cr}486 & 0.84 \\
& 57.687 \\
\end{array}$ & $\begin{array}{c}48.5 .81 \quad 1.24 \\
3.611 .284\end{array}$ \\
\hline MTNA URUGUAI & $\begin{array}{c}12.455 \\
315.219 \\
\end{array}$ & $\begin{array}{cr}7.994 & 1.50 \\
532.475 \\
\end{array}$ & $\begin{array}{|cc|}34.739 & 1,63 \\
2.132 .220 \\
\end{array}$ & $\begin{array}{|cc|}5.474 & 2.35 \\
232.821 \\
\end{array}$ & $\begin{array}{cc}901 & 1.27 \\
& 70.917 \\
\end{array}$ & $\begin{array}{c}61.623 \\
3.783 .651 \\
\end{array}$ \\
\hline FULAO SAOO JÚLIO & $\begin{array}{r}1.042,1.46 \\
71.350 \\
\end{array}$ & & 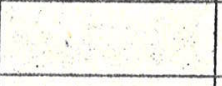 & & $\begin{array}{rr}327 & 1,58 \\
20.714 \\
\end{array}$ & $\begin{array}{c}1.369 \quad 1.49 \\
82.064 \\
\end{array}$ \\
\hline FILAO BARNABE & $\begin{array}{c}1.178 \quad 1,55 \\
75.300\end{array}$ & & & & & $\begin{array}{c}1.178 \quad 1,55 \\
75.390 \\
\end{array}$ \\
\hline ZONA INTERMEOIÁRIA & & $\begin{array}{|cc|}5.205 & 1,63 \\
\quad 319.000^{\circ} \\
\end{array}$ & & & & $\begin{array}{c}5.205 \quad 1.63 \\
319.000 \\
\end{array}$ \\
\hline TOTAL & {$\left[\begin{array}{cc}32.555 & 1,39 \\
2.340,835\end{array}\right.$} & \begin{tabular}{|cc}
24.962 & 1,43 \\
1.741 & 844 \\
\end{tabular} & $\begin{array}{r}51.148 \\
3.57 \\
3.257 .373 \\
\end{array}$ & $\mid \begin{array}{cc}7.676 & 1,96 \\
392.019\end{array}$ & $\begin{array}{cr}1.714 & 1,15 \\
149.318\end{array}$ & $\begin{array}{|cc|}118.056 & 1.49 \\
7.381 .389 \\
\end{array}$ \\
\hline $\begin{array}{l}\text { HORIZONTE INFERIOR DO } \\
\text { CONGLOMERADO VARGAS }\end{array}$ & & & 1.211 .000 & & & 1.211 .000 \\
\hline & & & & RESERVA & TOTAL - & 9.092 .389 \\
\hline
\end{tabular}

a) Reserva total

7. $881,389(t)$

b) Reserva total incluindo o Horizonte Inferior do Conglomerado Vargas

$9.092 .389(t)$

RESERVAS DETERMINADAS E PREVISTAS APOS 1971

1. Cêrro das Tunas, Oscarino e Feliciano (Reserva Inferida)

129. 275

2. Reserva Prevista para a Mina Uruguai até ao nível 1.200 pés. em função das sondagens profundas

a) Os teores obtidos da reserva total (1971), devem ser corrigidos (para menos), por un fator variável entre 15 a $20 \%$.

b) A reserva correspondente ao Horizonte Inferior do Conglomerado Vargas deve ser considerada como uma reserva marginal, sujeita a comprovação por trabalhos de pesquisa. Os teores previstos devem variar entre 1,0 a 1; $5 \%$ 


\section{IV. $3 \quad$ Lavra}

A mineração subterrânea é feita por "shrinkage stoping" em blocos de desmonte, havendo, no entanto, projetos para implantação de novos métodos, provavelmente "sub-level stoping". Além da mine ração subterrânea, a Zona Intermediária tem sido ocasionalmente lavrada a céu aberto, por bancadas, O minério foi dividido em painéis com altura de 30 a 35 metros. Os comprimentos dos blocos são variáveis e delimitados por chaminés. O desenvolvimento é iniciado em subnível, com largura e comprimento igual ao do bloco a ser desmontado. Pilares de 3 a 4 metros são deixados, delimitando verticalmente o bloco nos níveis contíguos. O transporte de minério é feito pelas galerias principais. Na Mina S. Luiz, o minério é escoa do pela Galeria Inglesa e pelo Poço Novo e a lavra atinge, atualmente, o nível 700 pés. Na Mina Uruguai a lavra se estende até ao nível 500 pés e o escoamento é feito por plano inclinado, que serve individual mente cada nível, estando em curso a construção de novo poço de extração a partir do nível 100 pés. Todo o minério é conduzido em vagonetas e caminhões até à estação de britagem e concentração dos engenhos Novo e Velho. 


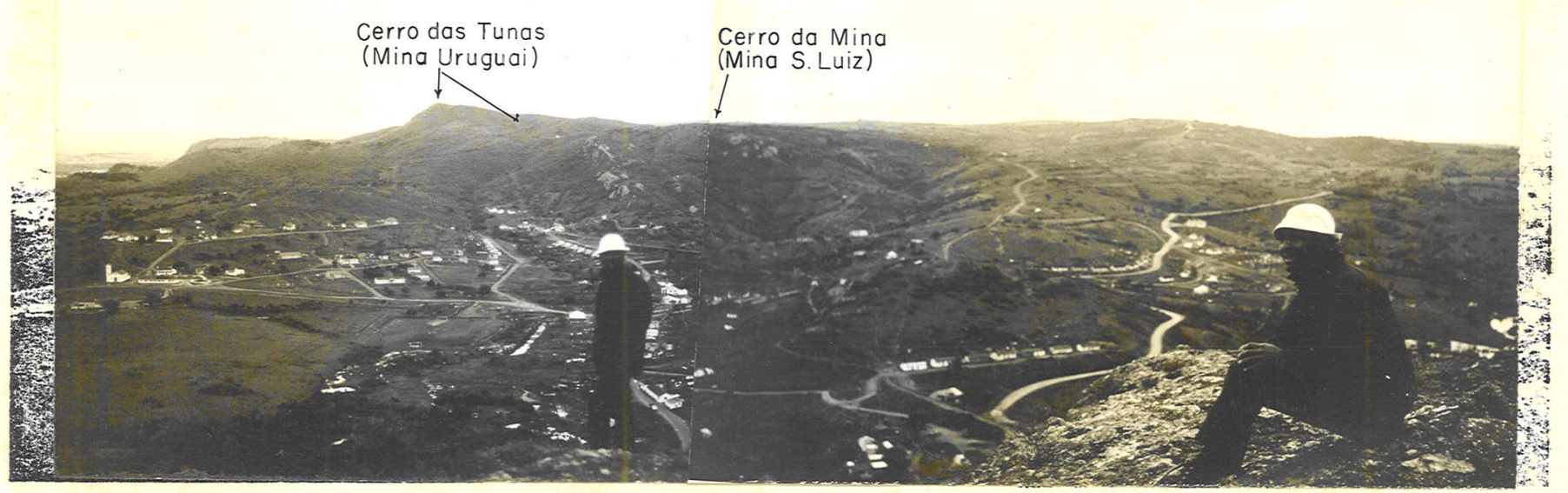

Foto 1 - Vista parcial do Distrito Cuprifero de Camaquã, a partir da Pedra do Paredão (Flanco NE). O espigão central é for mado pelo Conglomerado Vargas e contém as minas S. Luiz e Uruguai (Cêrro da Mina e Cêrro da Tuna). O flanco esquerdo é constituido pelo Arenitc Inferior e o direito contém o Arenito Superior. A formação Santa Bárbara aparece ao fundo à direita, recobrindo em discordância angular o Arenito Superior e Conglomerado Vargas. 


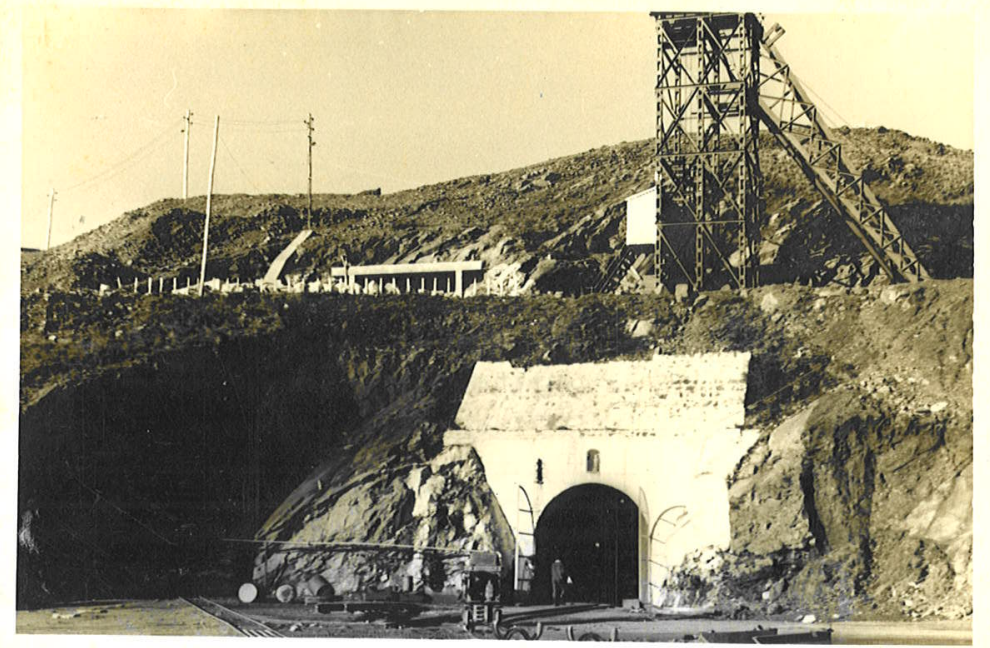

Foto 2 - Instalações do Poço Principal (Poço Novo) na Mina S. Luiz. Notar a entrada do Eoço e a torre dos elevadores.

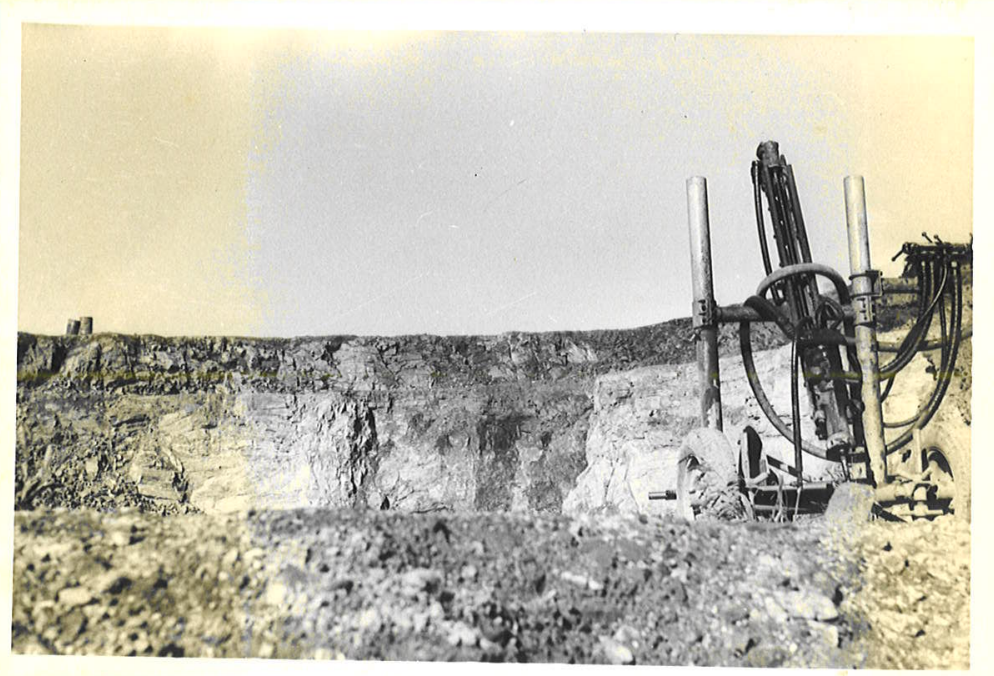

Foto 3-Feiçōes da lavra a céu aberto na Zona Intermediária. 
Para a identificação de minerais de minério, gangas, alteração hidro termal e estudo das rochas encaixantes do distrito, foram confecciona das 50 secções polidas, 40 secções delgadas de amostras de minério, além de 40 secções delgadas de rochas.

Todas as secções e lâminas foram estudadas, segundo métodos con vencionais em microscópio de fabricação Leitz, modelo Ortolux-pol e Zeiss, modelo Standard WL. As análises modais das rochas clásticas e ígneas foram obtidas por meio de contagem de pontos (Chayes, 1949), com espaçamento adequado à granulação da rocha, empregando-se um número mínimo de 700 pontos por lâmina, nas rochas sedimentares e 1000 pontos nos diabásios. Os resultados alcançados estão expressos em porcentagens volumétricas.

Os ângulos $2 \mathrm{~V}$ dos piroxênios foram medidos em Platina Universal Leitz de quatro eixos, diretamente, ou por projeção estereográfica. A composição dos plagioclásios foi obtida a partir do método da extin ção máxima usando-se os gráficos fornecidos por Tröger (1956) e o gráfico de Fouqué-Kohler (segundo Tróger, 1956).

O método da difraçäo de raios $X$ foi utilizado intensivamente no presente trabalho, para identificação e caracterização das espécies minerais. O método fotográfico em câmara de pó, de Debye Sherer, foi usado para a identificação da maioria dos minerais, individualizados ou em mistura de fases, quan do possível. Nos casos de difícil separação a partir de misturas, foram obtidos difratogramas, sendo os resultados corroborados com observaçōes óticas em lâminas delgadas e secçöes polidas. Foi utilizado equipamento de difração de marca Norelco com

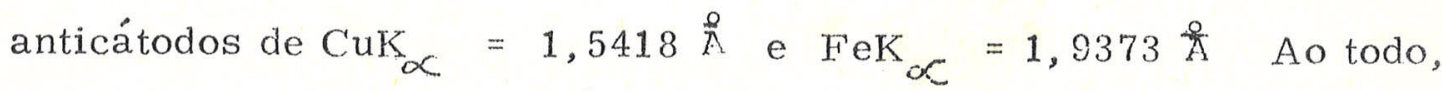
foram feitas 40 determinações de raios $\mathrm{X}$, sendo 16 pelo método do pó e 24 por difratometria. 
Para a déterminação dos elementos traço em pirita, calcopirita e he matita foram colhidas amostras de minério em níveis diferentes da Mina Camaquã e em corpos independentes, de maneira a melhor representar a distribuição, em profundidade dos elementos a serem analisados.

Sempre que possível foi dada preferência às amostras que contivessem pirita e hematita, bem cristalizadas e individualizadas, ou calcopirita livre de contaminação e intercrescimento de outros sulfetos.

Inicialmente o material foi reduzido a uma granulometria abaixo de 50 malhas, suficiente para liberar pirita e calcopirita. As fraçöes compreendidas entre 100 e 150 malhas foram conservadas, sendo pos teriormente lavadas com água destilada. No caso de hematita e pirita, foi possível obter algumas amostras de minério com cristais bem individualizados e livres de contaminações, que, após trituração, foram selecionados à lupa, por catação manual. No caso de hematita também foram obtidos concentrados purificados por simples separação com bromofórmio.

Todas as fraçōes de minério retidas nas peneiras 100 e 150 malhas foram submetidas a concentração, com a finalidade de separar os mi nerais de ganga existentes. Essa concentração foi efetuada no Depar tamento de Minas da Escola Politécnica, U.S.P., em mini-célula de flotação, especialmente desenhada para separações dessa natureza e usando compostos or gânicos de uso rotineiro em concentração de sulfetos. Os concentrados obtidos por meio dessa operação demonstra ram possuir ainda pequena contaminação de minerais de ganga, espe cialmente quartzo. Essas amostras foram levadas ao Separador Isodi nâmico Frantz, com o objetivo de obter concentrados puros de pirita e calcopirita, não contaminados por bornita e outros sulfetos. O pro cedimento e os parâmetros usados nesta operação foram descritos por Gaudin et al (1943) e Rosenblun (1958). 
Algumas amostras exigiram, ainda, separação final de impurezas de quartzo, por catação manual à lupa ou em bromofórmio.

Na determinação dos elementos traço e da composição química dos minerais de minério, concentrados e rochas, foram utilizadas: micro-sonda eletrônica, fluorescência de raios X e espectrofotometria de absorção atômica.

Todos os dados analíticos contantes da Tabela 12 foram obtidos por micro-sonda eletrônica, por intermédio do Laboratório de Geoquímica da Outokumpu Mining Company-Finland. Foram usados cristais de LiF e mica, sendo o aparelho operado a $25 \mathrm{Kv}$ e 0,1 1 A. Os padrões usados foram pentlandita, para $\mathrm{Ni}$ e Co, calcopirita, para $\mathrm{Cu}$, Fe e S em calco pirita, e pirita, para Fe e S. O limite de detecção de Co e Ni foi de 100 ppm, com os seguintes êrros estimados de determinação:

$\mathrm{S} \pm 0,3 \% ; \mathrm{Fe} \pm 0,4 \% ; \mathrm{Cu} \pm 0,4 \% ; \mathrm{Co} \pm 0,02 \% ; \mathrm{Ni} \pm 0,02 \%$.

As determinações analíticas feitas por fluorescência de raios $\mathrm{X}$, con sistiram na análise de microelementos, à exceção de Ni e Co, em 8 concentrados de pirita, 20 de calcopirita, 5 de hematita e 6 concentra dos de minério, além da análise total de 6 amostras de rochas. Estas amostras são do Granito Caçapava e andesitos Hilário e Rodeio Velho.

Nas dosagens de elementos traço em minerais não foram usados padrões internos, mas sim padrões minerais de pirita, calcopirita e hematita, previamente analisados por absorção atômica. Para o trabalho analítico em rochas foram utilizados os padröes W - L, AGV - 1, GSP - 1 do (United States Geological Survey), respectivamente para basalto, ande sito e granito. Os êrros estimados nas determinações por fluorescên cia de raios $X$ giram em torno de $\pm 20 \%$. 
A região de Caçapava do Sul - Lavras do Sul constitui a principal zona de mineralização de cobre no Estado do Rio Grande do Sul, abrangendo vários distritos cupro-auríferos. Pela sua importância econômica, tem merecido a atenção de dezenas de investigadores, cujos trabalhos, abordando diferentes aspectos geológicos regionais, ou detalhes sobre os recursos minerais da região, constituem extensa e volumosa lite ratura.

Uma síntese geral da evolução do conhecimento geológico regional torna-se necessária, para a compreensão da metalogenia do cobre no Distrito Cuprífero de Camaquã. Neste trabalho, somente as publica ções básicas, de interesse específico, serão resumidamente enumera das.

As primeiras observaçōes geológicas regionais, referentes à região, são de autoria de Paulino Franco de Carvalho (1932), que propôs uma sequência estratigráfica Pré-Itararé, compreendendo todas as rochas referidas ao Arqueano (gnaisses, granitos, dolomitos e micaxistos) e Algonquiano (Série Porongos), incluindo todos os filitos, xistos, quart zitos e andesitos, estes responsáveis pela mineralização de $\mathrm{Au}, \mathrm{Pb}$ e Cu. Ainda de sua autoria, é a Série Camaquã, na qual foram incluidas as rochas sedimentares clásticas.

Leinz, Barbosa e Teixeira (1941) apresentaram um mapa geológico da região Caçapava - Lavras, à escala 1:200.000, acompanhado de uma síntese geológica regional, com modificações importantes na estratigra fia, constituindo uma importante contribuição ao conhecimento da área.

Estes autores conservaram as divisões anteriormente propostas por Carvalho (1932), para as rochas pré-cambrianas. Na Série Porongos foram englobados os xistos epimetamórficos e granitos intrusivos. Foi também definida a Formação Maricá, posterior à Série Porongos, 
afetada por vulcanismo de quartzo-pórfiro e andesito. Esta Formação seria constituída por sedimentos clásticos, conglomerados arcózicos e arenitos. Ainda segundo os mesmos autores aos sedimentos da For mação Maricá, seguiu-se a deposição da Série Camaquã e o vulcanis mo andesítico, responsável pela mineralização de $\mathrm{Cu}$ e $\mathrm{Au}$.

Melcher e Mau (1960) resumiram os trabalhos geológicos efetuados na regiāo desde 1932 mais especificamente quanto à sequência geoló gica regional, e apresentaram um mapa geológico regional, de autoria de Melcher, Mau, Johnson e Robertson (1959).

Neste trabalho os autores excluiram a possibilidade de existência na área próxima a Caçapava, de rochas pertencentes ao pré-cambria no inferior. Observaram que a Série Maricá era a sequência regional mais antiga e nela foram incluídas não só as rochas sedimentares definidas por Leinz, Barbosa e Teixeira (1941), como também metas sedimentos, além de riólitos, andesitos e metabasitos. A esta Série segue-se uma fase de vulcanismo intenso, compreendendo rochas ácidas, básicas e intermediárias. Sobre estas rochas, assenta-se a Série Camaquã, com derrames e intrusões andesíticas subordinadas. Os granitos de Caçapava, Lavras e Ramada foram considerados intru sivos na Série Maricá e na sequência vulcânica.

Como complementação ao estudo dos investigadores referidos, Robertson (conforme citação de Ribeiro et al, 1966), com base em tra balhos de campo, propôs novas formaçōes. A Série Camaquã foi rede finida com o nome de Grupo Camaquã e subdividida nas formações Santa Bárbara, Guaritas e Conglomerado Coxilha. As rochas metas sedimentares circundantes do granito Caçapava foram englobadas no Grupo Porongos.

Goni, Goso e Issler (1962) propuseram modificações na coluna estra tigráfica, particularmente no pré-cambriano. 
Os conhecimentos geológicos do polígono cupro-aurífero do Rio Grande do Sul sofreram um notável progresso através do mapeamento geológi co sistemático, à escala 1:250.000, executado pela equipe de geólogos do D. N.P.M. - R.G.S., Ribeiro, Bocchi, Figueiredo Filho e Tessari (1966). Como decorrência deste trabalho, uma nova coluna geológica foi proposta, com profundas alterações estratigráficas. Na nova coluna foram englobadas as nomenclaturas anteriores, às vezes obser vando os conceitos originais e, em outros casos, redefinindo e sepa rando novas unidades.

Dando prosseguimento ao projeto para prospecção do cobre no $1 \%$ dis trito do D. N.P.M. - Extremo Sul, foram efetuados mapeamentos geo lógicos na área do grau de Caçapava - Lavras do Sul, em áreas prio ritárias e à escala 1:50.000 nes.quadrículas Passo dos Enforcados, Ca çapava do Sul, Bom Jardim e Mina de Camaquã (inédito). Como conse quência, Ribeiro (1970)no mapa geológico da fôlha de Bom Jardim, de monstra a necessidade de redefinições na nomenclatura; optou, entre tanto, por uma solução futura aguardando novos dados de geocronologia ou de trabalhos geológicos de detalhe.

As dificuldades de interpretação das relações de campo e, portanto, do estabelecimento de uma sequência estratigráfica segura, começa ram a ser resolvidas com determinações sistemáticas de idades radio métricas. Ribeiro e Carraro (1971), de posse de mapas de detalhe à escala 1:50.000, com as revisões pertinentes, conjugadas às datações de rochas, introduziram modificações importantes na estratigrafia, além de apresentarem uma interpretação global da geotectônica regional.

Minioli et al (1971) efetuaram determinaçōes de idades, pelo método $\mathrm{K}-\mathrm{Ar}$, em amostras de rochas extrusivas e intrusivas do núcleo Caça pava - Lavras, que de modo geral, são coerentes com o esquema estra tigráfico retrabalhado de Ribeiro e Carraro (1971). 
A Tabela 3, que apresenta as sequências estratigráficas da região de Caçapava - Lavras do Sul (segundo Melcher et al, 1960), complementa da com as colunas geológicas propostas por Ribeiro et al (1966) e Ribeiro e Carraro (1971), ilustra a evolução dos conceitos estratigrá ficos até à presente data e também a disparidade de opiniões dos in vestigadores da área. 


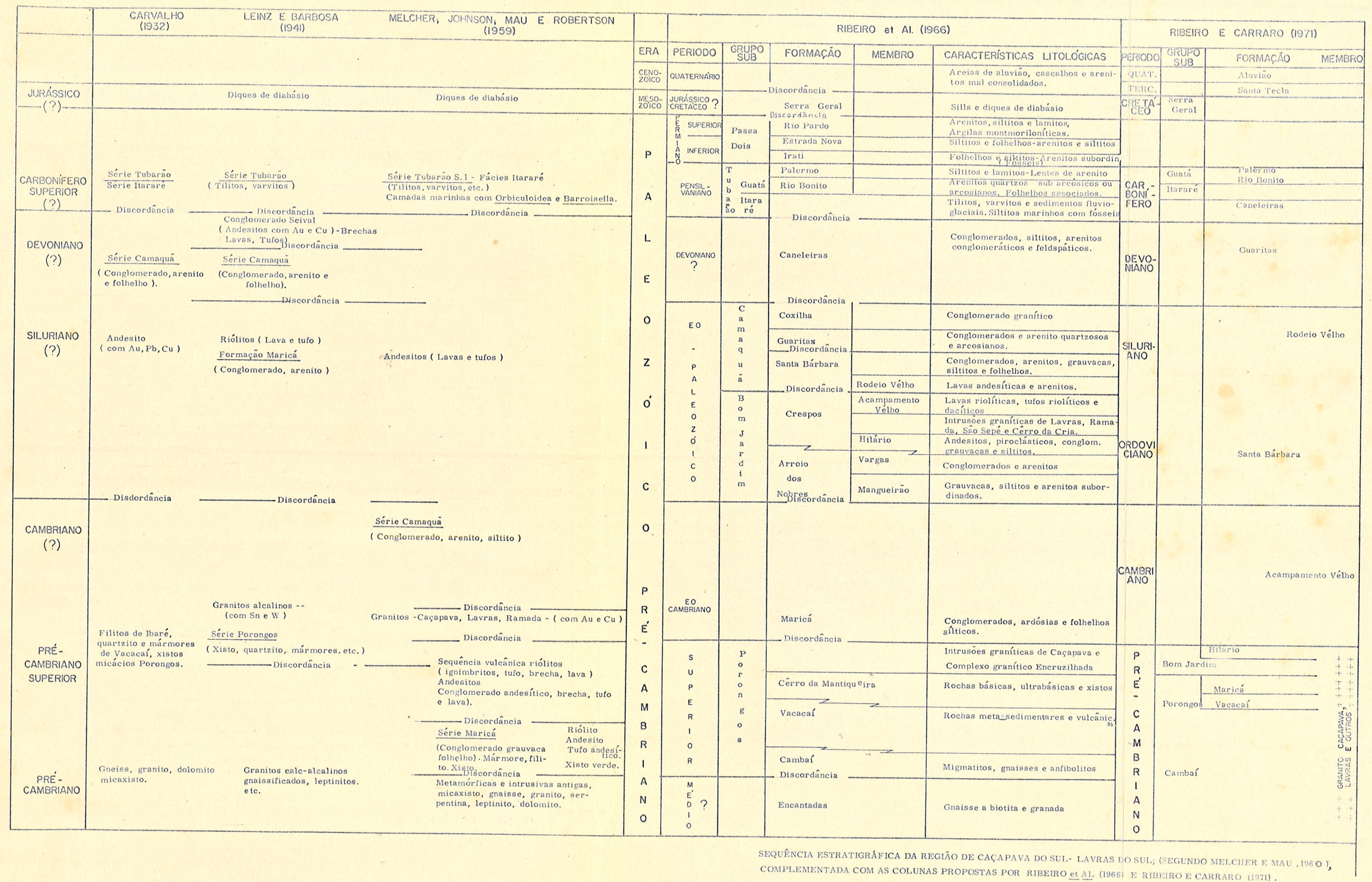


VII. $1 \quad$ Generalidades

Para a definição e caracterização das formações geológicas que ocor rem na região de Camaquã, especificamente quanto às suas idades e litologia, serão tomadas como base a coluna estratigráfica referente ao Grau de Caçapava, proposto por Ribeiro et al (1966) e sua concei tuação mais nova esboçada em Ribeiro e Carraro (1971). Consideran do o interesse e a importância das rochas encaixantes dos filóes de minério, elas serão descritas com detalhe adequado dentro dos limites do mapa geológico do distrito, em escala 1:6.000 (Fig. 3). As caracte rizações das formações em escala regional serão feitas resumidamente e acompanhadas de mapa geológico à escala 1:50.000 (Fig. 2). Este mapa representa uma porção da folha geológica da Mina de Camaquã, elaborada por Ribeiro et al (1966), modificada e completada com dados estratigráficos mais recentes de Ribeiro e Carraro (1971).

De acordo com a formulação mais recente de Ribeiro e Carraro (1971), na regiāo de Camaquã predominam rochas dos Grupos Bom Jardim e Camaquã, pertencentes ao Pré-Cambriano Superior e Eo-Paleozóico (Cambriano, Ordoviciano e Siluriano), respectivamente.

Ainda segundo os mesmos autores, os sedimentos do Grupo Bom Jar dim, à semelhança da Formação Maricá, estratigraficamente inferior, apresenta características de sequência terrígena superior de ambiente parageossinclinal. No Grupo Bom Jardim, entretanto, há associação com vulcanismo andesítico intenso, representado por rochas intrusivas, tufos e lavas.

As rochas do Grupo Camaquã seriam verdadeiras molassas, formadas em bacias intermontanas e antefossas, com vulcanismo intermitente.

Diques de diabásio relacionados ao episódio vulcânico mesozóico do sul do Brasil também ocorrem, subordinadamente, preenchendo fraturas de direção NW. 
Estas, segundo Almeida (1966), seriam antigas fraturas pré-cambria nas posteriormente afetadas pela "Reativação Wealdeniana".

Depósitos sedimentares aluvionares de idade quaternária também ocorrem na área e constituem preenchimento de calhas e margens dos rios.

O esquema abaixo resume a sequência estratigráfica extraída de Ribeiro et al (1966), complementada de acordo com as modificações introduzidas por Ribeiro e Carraro (1971). Nesta sequência figuram somente as formações aflorantes na área (Fig. 2).

Cenozóico Quaternário

Mesozóico

Paleozóico $\left\{\begin{array}{l}\text { Devoniano } \\ \text { Siluriano } \\ \text { Ordoviciano }\end{array}\right.$

Pré-Cambriano

\section{Cretáceo}

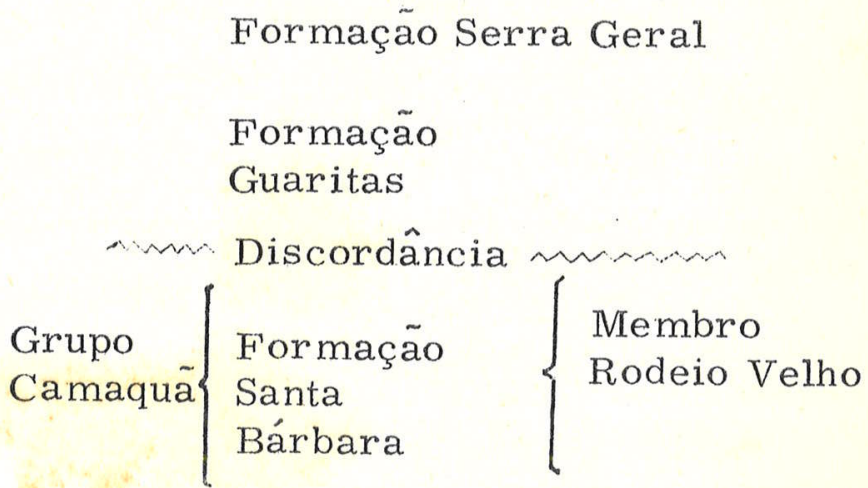

Formação Serra Geral

Formação

Grupo
Camaquä $\left\{\begin{array}{l}\text { Formação } \\ \text { Santa } \\ \text { Bárbara }\end{array} \quad\left\{\begin{array}{l}\text { Membro } \\ \text { Rodeio Velho }\end{array}\right.\right.$
Aluviões

Guaritas

Grupo
Jardim $\left\{\begin{array}{l}\text { Formação } \\ \text { Arroio dos } \\ \text { Nobres }\end{array} \quad\left\{\begin{array}{l}\text { Membro } \\ \text { Vargas } \\ \text { Membro } \\ \text { Mangueirão }\end{array}\right.\right.$ 
VII. 2

No Distrito Cuprífero da Mina de Camaquã, as rochas do Grupo Bom Jardim formam uma estrutura homoclinal, em discordância angular ou em contato de falhamento com a Formaçäo Santa Bárbara, sotopos ta. Ocupam ao mesmo tempo, o núcleo de uma estrutura anticlinal com caimento para NE, em cuja zona axial erodida está exposta a Formação Arroio dos Nobres.

Regionalmente as direçöes das camadas variam de $\mathrm{N}$ a $\mathrm{NE}$ com mer gulhos variando de 30 a a 60 \% NW. Estas atitudes podem sofrer modi ficações, devidas a pertubações tectônicas locais.

\section{2.1 Formação Arroio dos Nobres}

Esta formação, definida por Tessari (1966), engloba rochas sedimen tares que ocorrem junto ao Arroio dos Nobres, a SW de Pinheiro, no Município de Encruzilhada do Sul. Situa-se entre a Formação Maricá, mais velha, e o Grupo Camaquā, mais novo. Ribeiro et al (1966, pgs. 85 e 86) subdividem esta for mação em dois membros, Mangueirão e Vargas, cujas relações de contato são simples, havendo mudanças litológicas graduais. No campo, a individualização é feita pelo padrão topográfico mais saliente do Membro Vargas. Regionalmente, as ca madas tem direções variando entre $\mathrm{N} 45 \mathrm{E}$ e N/S, com mergulhos de $20 \%$ a $45 \circ \mathrm{NW}$ a W.

\section{VII.2.1.1 Membro Mangueirão}

O Membro Mangueirāo é caracterizado por espessa sequência de are nitos, predominantemente grauvacas, e arenitos arcózicos subordina dos, ritmicamente intercalados com siltitos, folhelhos sílticos ou grau vacas finas. Os arenitos formam camadas maciças ou laminadas de 5 centímetros a 1 metro de espessura. Os siltitos intercalados de colo ração vermelha escura, possuem estrutura microlenticular e lamina ção bem desenvolvida. 


\section{VII.2,1.2 Membro Vargas}

Nas zonas de exposição do Distrito de Camaquã, o Membro Vargas jaz sotoposto ao Membro Mangueirão, segundo contato transicional. No topo, está recoberto por rochas da Formação Santa Bárbara, em discordância angular.

Apresenta estratos de conglomerado, com espessura superior a 50 metros, e intercalações subordinadas de arenitos arcózicos de espes sura centimétrica a métrica.

Os seixos do conglomerado são de granito, xisto, quartzito, gnaisse, milonito, arenito, quartzo leitoso e feldspatos, e o material intersti cial é constituido por argila, material clorítico éxidos de ferro.

As dimensões dos seixos variam, em média, de 5 a 10 centímetros de diâmetro, mas podem ocorrer matacões com dimensões de até 1 metro.

VII. 3 Grupo Camaquä

As rochas pertencentes a este Grupo foram inicialmente englobadas sob a designação de Série Camaquã, por Carvalho (1932), sendo poste riormente redefinidas por Leinz, Barbosa e Teixeira (1941), como Formação Camaquã. Robertson (1961), abandonou essas conceituações e caracterizou uma sequência litológica de características continentais, com aproximadamente 4.000 metros de éspessura, a que ele chamou de Grupo Camaquã. Das três for maçōes em que foi subdividida, Santa Bárbara, Guaritas e Conglomerado Coxilha, somente as duas primeiras, ocupando grande parte da área, ocorrem na região de Camaquã. 
VII. 3.1 Formação Santa Bárbara

Como já foi assinalado anteriormente, esta formação sobrepõe-se em discordância angular ao Membro Vargas da Formação Arroio dos Nobres, sendo capeada, também em discordância, pela Forma ção Guaritas. Contatos por falhamentos com o Membro Mangueirão são também assinalados na área.

No Distrito Cuprífero de Camaquã, a Formação Santa Bárbara é representada por: conglomerados de composição e características variáveis; arenitos arcózicos laminados em estratos de 30 a 40 centímetros de espessura com intercalações subordinadas de siltitos e folhelhos sílticos ou argilosos; grauvacas laminadas em estratos maciços; arenitos conglomeráticos com intercalações delgadas de conglomerado.

Os conglomerados apresentam estratificação cruzada bem desenvol vida, indicativa de deposição em canais em regime torrencial. Diver sas intercalaçōes andesíticas são encontradas nos arenitos da Forma ção Santa Bárbara. Esses vulcanitos foram agrupados sob a designa ção de Membro Rodeio Velho.

\section{3.1.1 Membro Rodeio Velho}

A Sul e Este do Distrito Cuprífero de Camaquã, ocorrem derrames de lavas andesíticas que foram englobadas por Ribeiro (1966, segundo Ribeiro 1966 pg. 117) no Membro Rodeio Velho da Formação Santa Bárbara. Estas rochas constituem lavas típicas e se intercalam em concordância com os arenitos da Formação Santa Bárbara. Segundo o mesmo autor, estes derrames são de andesitos vesiculares, que assumem côres avermelhadas resultantes de oxidação superficial. 


\section{3.2 Formação Guaritas}

A Formação Guaritas, separada por discordância das formações mais velhas, ocupa grande parte da área de Camaquã, especialmente na porção norte. É constituída por espessos bancus de arenitos e conglo merados horizontais, em geral com estratificação cruzada, e subdivi dida em duas fácies, uma fanglomerática e outra subaquosa.

As litologias predominantes na fácies fanglomerática são conglomera dos e arenitos conglomeráticos, intercalados com espessos bancos lenticulares de arenito arcózio quartzoso. Nas fácies subaquosa predominam arenitos quartzosos arcózicos, ou subarcózicos, grauva cas, siltitos e conglomerados subordinados.

VII. 4 Caracterização Local das Litologias

VII. 4.1 Generalidades

Os trabalhos de sondagem profunda, efetuados na Mina de Camaquã, permitiram a obtenção de amostras frescas para estudo microscópico das diferentes rochas encaixantes.

Os trabalhos de geologia de detalhe, em conjunção com os dados de sondagem efetuados na zona da Mina, possibilitaram localmente, a subdivisão do Membro Vargas em vários horizontes, em função das variaçōes litológicas. Essa subdivisão foi necessária, em virtude da sua importância em relação aos controles de mineralização e proble blemas mineiros concernentes. Entretanto, deve-se assinalar, que essa subdivisão é restrita, não havendo qualquer compromisso com a estratigrafia regional, oficialmente estabelecida. Serão adotados, também, os critérios de definição e separação dos Membros Vargas e Mangueirão, de Ribeiro et al (1966, pg. 88). O mapa geológico de distrito (Fig. 3), ora apresentado, deve ser encarado como um mapa preliminar, uma vez que grandes porções da área necessitam de tra balhos mais detalhados, indispensáveis ao melhor conhecimento estru tural e de controle de mineralização. 
Para a caracterização das litologias arenosas serão adotados os crité rios de nomenclatura propostos por Pettijohn, Potter e Siener (1972, pgs. 155, 158, 159).

\section{4.2 Membro Mangueiräo}

A estratificação rítmica é típica deste Membro (Fot. 4 ). Observações em testemunhos de sondagem das Zonas Oscarino e Feliciano, mostram que as camadas de arenito são centimétricas a decimétricas, raramen te ultrapassando 1 metro de espessura; alternam-se com ritmitos, caracterizados por alternâncias de lâminas de siltitos e arenitos finos a muito finos. As direçōes das camadas são $\mathrm{N} 45 \mathrm{E}$ a N/S, com mer gulhos oscilando entre $20 \%$ e $45 \% \mathrm{NW}$ e W, respectivamente.

\section{4.2.1 Arenitos}

Os arenitos podem ser maciços ou apresentar acamamento bem desen volvido. A cor marrom predomina, mas também ocorrem variedades rosadas a avermelhadas.

Particularmente, nas zonas sujeitas a alteração hidrotermal podem exibir coloração cinza clara ou tonalidade esverdeada, quando há pre dominância de cloritização.

Textura clástica, classificação regular e empacotamento frouxo, carac terizam esses arenitos. Os componentes clásticos, principalmente quartzo e feldspatos, são subangulares, às vezes angulares, e estão dispersos em matriz constituída por clorita, sericita e minerais argi. losos (Fot. 6 ). As micas mostram-se alinhadas e paralelas ao acama mento.

As dimensões dos grãos dos componentes clásticos principais variam de 0,01 a 0,5 milimetros, conferindo granulação fina a média à rocha. 
Os minerais da matriz são abundantes nestas rochas, variando entre 10 a $26 \%$ do volume total nas amostras estudadas. Seus constituintes são, clorita, minerais argilosos, sericita e quartzo de granulação fina a muito fina. A matriz apresenta associação íntima e substituição por cimento calcítico abundante cuja porcentagem volumétrica varia entre 20 e $44 \%$, além de 2,2 a $6,4 \%$ de óxidos de ferro.

Quartzo é o mineral detrítico mais importante, ocorrendo em varieda des mono e policristalinas, conforme definido por Pettijohn et al, 1972 (pg. 30). O conteúdo médio de quartzo nas lâminas observadas, varia de 20 a $30 \%$. Como quartzo policristalino são incluídos os fragmentos, provavelmente resultantes de rochas graníticas, gnaisses, quartzito e silexito, que, em conjunto, ultrapassam $7 \%$.

Os feldspatos são plagioclásios da variedade oligoclásio e feldspato potássico subordinado, normalmente microclínio. Embora ocorram cristais inalterados, nota-se que, via de regra, os feldspatos estão alterados a caolinita, sericita e mesmo calcita, polvilhando e reco brindo a superfície dos grãos individuais. A análise modal indica pro porção de feldspatos variando de 1, 6 a 4,8\% (Tabela 4).

Ao lado dos fragmentos de quartzo policristalino referidos, são encon trados fragmentos de xistos micáceos e cloríticos; quartzitos finos com textura granoblástica, apresentando conteúdos variáveis de sericita e clorita e agregados sericítico-cloríticos, de difícil caracterização ao microscópio. Em conjunto, estes componentes ocupam volume entre os limites 7,7 a $9,1 \%$.

Os minerais micáceos, predominantemente represéntados por clorita, muscovita e sericita, são prismáticos, alongados e subparalelos ao acamamento (Fot. 5 ).

Os componentes detríticos acessórios nunca ultrapassam $1 \%$ da rocha, sendo representados por titanita, apatita, turmalina, zircão e opacos. 
A composição modal de 3 amostras de arenitos representativos do Membro Mangueirão, apresentada na Tabela 4, embora em número restrito, permite concluir que, na faixa estudada, predominam are nitos, incluídos no grupo dos "wackes", caracterizados como grauva cas líticas, além de arenitos sublíticos em escala subordinada, con forme classificação proposta por Pettijohn et al (1972).

Deve-se assinalar que todas as análises modais das rochas sedimenta res, constantes deste trabalho, foram efetuadas em amostras prove nientes da área da Mina e os resultados só tem significado local. Em muitos casos há sobreposição de alteração hidrotermal, podendo ocor rer valores elevados de cimento calcítico ou mesmo matriz clorítica e sericítica.

\section{TABELA 4}

COMPOSIÇÃO MODAL DE ARENITOS DO

MEMBRO MANGUEIRĀO

(ZONA FELICIANO)

\begin{tabular}{|l|c|c|c|}
\hline \multicolumn{1}{|c|}{ Componentes } & $\begin{array}{c}\text { Fe- } 71-1 \\
(174 \mathrm{~m}) \\
\%\end{array}$ & $\begin{array}{c}\text { Fe- } 71-1 \\
(67 \mathrm{~m}) \\
\%\end{array}$ & $\begin{array}{c}\text { Fe- } 71-1 \\
(87 \mathrm{~m}) \\
\%\end{array}$ \\
\hline Quartzo & 29,6 & 30,5 & 24,0 \\
Feldspato & 4,5 & 4,8 & 1,6 \\
Fragmentos de Rochas & 9,1 & 9,3 & 7,7 \\
Matriz\{ Clorítica- & & & \\
Sericítica & 10,0 & 26,7 & 15,0 \\
Limonita & 6,4 & 2,2 & 2,9 \\
Cimento Calcítico & 36,0 & 20,0 & 44,1 \\
Mica e Clorita & 1,7 & 4,6 & 3,6 \\
Opacos & 2,4 & 2,0 & 0,1 \\
Acessórios & 0,5 & 1,0 & 0,6 \\
\hline
\end{tabular}




\section{4.2.2. Ritmitos}

Os ritmitos apresentam aspecto extremamente laminado. Os leitos individuais possuem cor cinza clara, cinza esverdeada e marron, alternadas, e suas espessuras, variam entre 0,1 e 4 milímetros. Em algumas amostras, o aspecto é macroscopicamente maciço, mas ao microscópio o ritmismo das camadas é prontamente ressaltado.

As lâminas cinza claras e escuras, constituídas por arenito muito fino, alternam-se com siltitos argilosos marrons.

A estratificação é muito bem desenvolvida e em algumas amostras observam-se estruturas primitivas, tais como gretas, estratificação cruzada, acamamento gradacional e deformações produzidas por fe nômenos de deslizamento (Fot. 5 ).

Os leitos de arenitos finos possuem constituição mineralógica bastante semelhante aos arenitos do mesmo membro. Os minerais detríticos estão embebidos em matriz abundante constituida por minerais argilo sos verdes, micrólitos de clorita e sericita, além de quartzo muito fino. As lâminas escuras, constituídas por siltitos argilo-ferruginosos, po dem apresentar variações graduais na vertical, havendo predominância absoluta de argilas e óxidos de ferro. Neste caso a matriz argilosa sofre forte pigmentação por limonita, sendo difícil a observação dos componentes detríticos presentes. Cimento predominantemente calcíti co é abundante em todos os leitos dos ritmitos.

Os componentes essenciais são quartzo, feldspatos, e quantidades pon deráveis de minerais micáceos (clorita, muscovita e sericita); estes, juntamente como o quartzo, apresentam-se fortemente orientados, com os eixos maiores paralelos ao acamamento (Fot 7).

Os minerais acessórios são os mesmos dos arenitos, predominando titanita, apatita, zircão e opacos. 
VII. 4. $3 \quad$ Membro Vargas

Para a separação dos Membros Vargas e Mangueirão, foi utilizado o contato determinado por Ribeiro et al (1966 - Fig. 2)。 O Membro Mangueirão passa gradualmente a espesso pacote de arenitos e siltitos, que constitue a parte inferior do Membro Vargas. A espessura desse pacote é variável entre 500 e 660 metros. Na parte superior estes arenitos passam a conglomerados com intercalações arenosas, que por sua vez, variam gradualmente a arenitos. Ainda nos limites do distrito, o membro Vargas é recoberto, em discordância angular, pela Formação Santa Bárbara. A atitude média das camadas determina da estatisticamente é N $599 \mathrm{E}-32$ NW. As subdivisões adotadas na Zona da Mina cuja justificativa foi referida anteriormente, é a seguinte: Membro Vargas $\left\{\begin{array}{l}\text { Arenito Superior } \\ \text { Conglomerado Vargas } \\ \text { Arenito Inferior }\end{array}\left\{\begin{array}{l}\text { Horizonte Superior } \\ \text { Arenito Medio } \\ \text { Horizonte Inferior }\end{array}\right.\right.$

\section{4.3.1 Arenito Inferior}

A sequência de rochas sedimentares classificadas com Arenito Inferior, é formada por bancos métricos de arenito alternados cılicamente com siltitos; entretanto, intercalaçōes subordinadas, caracterizadas por alternância de camadas de arenitos finos, com espessura de 0,8 a 3 centímetros, com ritmitos constituídos por lâminas de arenitos finos e siltitos argilosos. Os leitos síltico-argilosos dos ritmitos algumas vezes apresentam lâminas predominantemente constituidas por limoni ta, minerais argilosos, quartzo e micas de espessuras em torno de 0,05 milímetros. A feição predominante nos ritmitos é a porcentagem grande de minerais micáceos que se dispõem fortemente orientados pa ralelamente ao acamamento.

As estruturas predominantes são plano-paralelas, ocorrendo também estruturas de escavação, gretas e deformações produzidas por escor regamentos. 
A superfície os arenitos apresentam coloração vermelho escura ou chocolate, creme esverdeado, rosa e cinza claro, esta predominando em profundidade.

A textura é clástica e os grãos estão frouxamente compactados. Os componentes são quase angulosos, notando-se, entretanto, fragmentos de rocha formados por aglomerados sericiticomcloriticos, com contornos quase arredondados. A granulação é muito fina. Os diâmetros dos grãos variam de 0,6 a 0,05 milímetros, havendo uma frequência maior de gräos de diâmetros em torno de 0,2 a 0,6 milímetros.

A matriz é abundante sendo predominantemente constituida por agrega dós cloríticos, minerais argilosos, cristais de sericita e quartzo muito fino e varia entre 8 a $34 \%$ do volume da rocha. O cimento calcí tico tem distribuição bastante irregular.

Os componentes detríticos principais são: quartzo, fragmentos de rochas e feldspatos, além de pequenas quantidades de filosilicatos, minerais acessórios e opacos.

Quartzo nas formas mono e policristalinas são os minerais predomi nantes. Os grãos são quase angulosos e algumas vezes se distribuem. paralelamente ao acamamento.

Os feldspatos são representados por plagioclásio (oligoclásio) e micro clínio. Apresentam-se alterados a sericita e caolim, notando-se algu mas vezes corpos puntiformes de óxidos de ferro e calcita dispersos na massa. A proporção dos feldspatos varia de 7 a $11 \%$.

Os fragmentos líticos são essencialmente constituidos por agregados sericítico-cloríticos, quartzitos finos, xistos micáceos e cloríticos. A análise modal indica que as suas proporções variam de 9 a $13 \%$. 
Os minerais micáceos são representados por muscovita e clorita. São prismáticos, fibrosos e, via de regra, apresentam orientação paralela ao acamamento.

Os componentes acessórios principais são apatita, zircão e titanita que em conjunto com os minerais opacos tem as suas proporções variando entre 4 a $10 \%$.

A Tabela 5 mostra a composição modal de 3 amostras de arenitos, colhidos em profundidade. Conforme classificação de Pettijohn et al (1972), essas rochas tem composição de grauvacas líticas, arcózios e subarcózios.

TABELA 5

ANÅLISE MODAL DE ARENITOS

(ARENITO INFERIOR)

\begin{tabular}{|l|c|c|c|}
\cline { 2 - 4 } \multicolumn{1}{c|}{} & $\begin{array}{c}\text { SL-71-10 } \\
(374 \mathrm{~m}) \\
\%\end{array}$ & $\begin{array}{c}\text { SL-71-10 } \\
(318 \mathrm{~m}) \\
\%\end{array}$ & $\begin{array}{c}\text { JB- 71-10 } \\
(383 \mathrm{~m}) \\
\%\end{array}$ \\
\hline Quartzo & 49,5 & 37,2 & 30,4 \\
Feldspato & 7,2 & 16,0 & 11,4 \\
Fragmentos de Rochas & 13,2 & 10,7 & 9,2 \\
Matriz & 18,7 & 8,8 & 34,4 \\
Cimento Calcítico & - & 20,4 & - \\
Limonita & 1,2 & 2,1 & 4,2 \\
Opacos & 4,8 & 3,1 & 6,6 \\
Filosilicatos & 3,6 & 1,5 & 3,8 \\
Acessórios & 1,8 & 0,2 & - \\
\hline
\end{tabular}




\section{4.3.2 Conglomerado Vargas}

Os conglomerados que ocorrem na Mina, denominados de Conglome rados Vargas, foram reunidos em dois horizontes, Superior e Infe rior, separados por um banco de arenito, aqui chamada Arenito Mé dio, cuja espessura aproximada é de 20 metros. A espessura do Ho rizonte Superior oscila entre 220 e 250 metros e do Inferior entre 70 e 80 metros. Os conglomerados do Horizonte Superior são de granula ção mais grossa e apresentam escassas intercalações de arenitos,

Entretanto, deve-se assinalar que, para o topo, nos limites de tran sição para o Arenito Superior, as intercalações se tornam mais fre quéntes. O Horizonte Inferior é predominantemente constituido por bancos e camadas de conglomerados com intercalações frequentes de arenitos conglomeráticos ou não.

Suas características estruturais observadas concordam com a descri ção de Ribeiro et al, já referida (pg. 28).

As côres são normalmente avermelhadas ou marrons quando há pre dominância de matriz limonítica e argilosa. Nas zonas de alteração hidrotermal podem apresentar cor verde, chocolate ou cinza esverdea da.

Foram observadas difernças consideráveis na composição dos seixos e também da matriz dos conglomerados, possivelmente devidas a diferenças na composição das rochas da superfície erodida.

A litologia dos seixos observados é variada predominando rochas de composição granítica, quartzitos, milonitos, cataclasitos, feldspatos, quartzo mono e policristalino, vulcanitos, xistos, rochas quartzo-fel dspáticas, além de fragmentos de rochas sedimentares. 
O material da matriz entre os seixos pode serabundante ou escasso, conforme a zona e sua granulação varia de fina a média, podendo eventualmente ser grosseira. É constituída predominantemente por clorita, minerais de argila, e finos grãos de quartzo. Óxidos de ferro e carbon_atos, principalmente calcita, podem constituir cimento, subs tituindo a matriz e englobando os materiais detríticos.

Apesar da grande variabilidade nos dois horizontes, foi tentada uma melhor caracterização das unidades na região da Mina, pela determi nação da composição modal dos conglomerados, em secções delgadas de testemunhos de sondagem até à profundidade de 400 metros. Os resultados da análise estatística de quatro amostras estão resumidos na Tabela 6. Grânulos cuja composição varia desde granitos nor mais a granodioritos e tonalitos, apresentando quase sempre, coloração cor de carne, são aqui agrupados sob a designação genérica rochas graníticas.

Os constituintes dos seixos graníticos são de granulação fina a gros-seira, e possuem textura hipidiomórfica granular. Seus principais componentes são feldspato potássico (microclínio e ortoclásio), oligo clásio e quartzo; hornblenda, biotita, clorita e minerais opacos ocor rem em pequena porcentagem, além de apatita e zircão.

Milonitos e cataclasitos de rochas graníticas e quartzo-feldspáticas ocorrem em grande porcentagem sendo juntamente com as rochas graníticas, os constituintes maiores dos conqlomerados.

Os seixos quartzíticos dos conglomerados podem ser praticamente puros ou apresentarem porcentagens subordinadas de sericita, clorita, opacos e, muito raramente, feldspatos e zircão. Esses quartzitos a presentam textura granoblástica e granulação fina. Os grãos são apro ximadamente equidimensionais, imbricados entre si ou fortemente alongados segundo direção preferencial, conferindo características 
xistosas à rocha. No caso de quartzitos sericíticos e cloríticos, os cristais de clorita e sericita estão orientados segundo o alongamento dos grão de quartzo. Os quartzitos muito frequentemente estão cata clasados, apresentando grãos menores moídos e textura em moldura.

Fragmentos e seixos de rochas designados vulcanitos, tem grande dis tribuição nos conglomerados. Exibem coloraçäo marrom ou pardacenta e a textura é afanítica. Apresentam-se fortemente alterados. Trata-se de rochas finíssimas, nas quais se observam fenocristais de quartzo em matriz extremamente fina, constituída por quartzo, feldspato e clorita. Outras vezes, essas rochas, ainda com granulação finíssima, são constituidas por microfenocristais ripiformes de feldspato (plagio clásio ?), extremamente alterados e dispersos, na maioria das vezes em massa, em geral, clorítica. A clorita, que deve ser proveniente da alteração de minerais ferromagnesianos, é acompanhada de peque na quantidade de feldspatos, quartzo, minerais opacos limonitizados e sericita, esparsos na massa clorítica. Em grânulos semelhantes que não possuem fenocristais, a clorita é dominante, os feldspatos são ripiformes e alterados, e as porcentagens de opacos e quartzo são desprezíveis.

Os componentes líticos que apresentam estrutura xistosa são muscovi ta quartzo - xisto e muscovita - xisto. Nos primeiros, os cristais são normalmente alongados, ocorrendo quartzo como mineral dominan te. A muscovita é subordinada, havendo também porcentagem ínfima de opacos. Os muscovita - xisto apresentam textura lepidoblástica.

Os feldspatos mais comuns nos conglomerados, são variedades potás sicas (ortoclásio e microclínio) às vezes pertíticos, com ou sem gemi nação em grade, além de plagioclásios (em geral oligoclásio). Possuem cor tijolo predominante. Muitas vezes estäo fortemente sericitizados e caolinizados, mas podem também mostrar intensa pigmentação casta nha escura resultante de óxidos de ferro. Os feldspatos podem apresen tar inclusões de quartzo, originando textura poiquilítica, além de inclusões de micropegmatitos. 
Os cristais de quartzo, alotriomórficos, apresentam as variedades mono e policristalinas. Frequentemente estão envoltos por película de óxido de ferro. Cristais de clorita, muscovita, zircão, apatita, tam bém ocorrem como minerais acessórios.

\section{TABELA 6}

COMPOSIÇÃO MODAL DE CONGLOMERADOS

DA MINA DE CAMAQUÃ

(HORIZONTES SUPERIOR E INFERIOR)

\begin{tabular}{|c|c|c|c|c|c|}
\hline \multicolumn{2}{|c|}{ Componentes } & $\begin{array}{c}\text { SL- } 71-10 \\
(212 \mathrm{~m}) \\
\%\end{array}$ & $\begin{array}{l}\text { AM-1 } \\
\%\end{array}$ & $\begin{array}{c}\mathrm{SL}-71-10 \\
(64 \mathrm{~m}) \\
\%\end{array}$ & $\begin{array}{l}\mathrm{SL}-71-10 \\
(180 \mathrm{~m}) \\
\%\end{array}$ \\
\hline \multirow{14}{*}{ 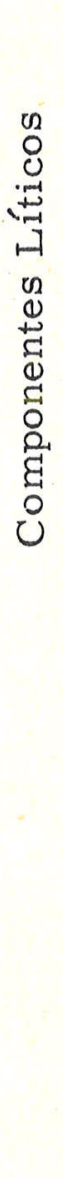 } & Rochas Graníticas & 29,2 & 13,8 & 22,1 & 23,0 \\
\hline & Milonitos e Cataclasitos & 30,7 & 16,6 & 10,6 & 16,8 \\
\hline & Rochas $\left\{\begin{array}{l}\text { Quartzo- } \\
\text { Feldspáticas }\end{array}\right.$ & 0,4 & 3,4 & 0,3 & 1,3 \\
\hline & Quartzitos & 4,3 & 11,0 & 9,7 & 14,0 \\
\hline & Vulcanitos & 10,5 & 3,7 & 2,9 & 1,2 \\
\hline & Xistos & 0,2 & 2,8 & 2,6 & 1,0 \\
\hline & Agregados $\left\{\begin{array}{l}\text { Sericítico- } \\
\text { Cl oríticos }\end{array}\right.$ & - & 0,1 & 1,2 & 2,0 \\
\hline & Feldspato & 8,0 & 19,6 & 24,7 & 14,7 \\
\hline & Quartzo & 2,2 & 12,2 & 11,5 & 12,7 \\
\hline & Matriz & 6,0 & 13,7 & 9,5 & 11,2 \\
\hline & Cimento Calcítico & 7,2 & 0,8 & 2,2 & 0,8 \\
\hline & Micas & 1,2 & 0,4 & - & - \\
\hline & Opacos & 0,1 & 0,7 & 2,4 & 1,2 \\
\hline & Acessórios & - & 0,2 & 0,3 & 0,1 \\
\hline
\end{tabular}




\section{4.3.3 Arenito Médio e Arenitos Intercalados}

Em associação íntima com os conglomerados, ocorrem intercalações de arenito, por vezes conglomerático, cujas espessuras variam de centímetros a metros. Macroscopicamente as rochas exibem tonalida des diversas predominando a cor chocolate, com pontilhamentos brancos devidos a feldspatos alterados; as côres cinza clara e mar rom predomiam em profundidade. Os arenitos podem ser maciços e outras vezes apresentam planos de acamamento incipientes.

Sua matriz possue composição variável, via de regra, constituída por microcristais de sericita, minerais verdes de argila, agregados cloríti cos e quartzo fino. Os componentes detríticos da rocha podem estar cimentados por óxidos de ferro (limonita) e calcita, esta substituindo a matriz.

Nos arenitos conglomeráticos ocorrem os mesmos grânulos encontra dos nos conglomerados, já descritos. Os componentes principais destas rochas, quartzo e feldspatos são quase angulares, com formas discóides ou alongadas. Os cristais de feldspato conservam a forma prismática, embora sejam quase angulosos nas proximidades. Os componentes estão dispostos em empacotamento frouxo, às vezes den so, sendo que neste caso há algum imbricamento dos constituintes.

Os arenitos mais finos são constituídos por quartzo, mono e policris talino, feldspatos, quartzitos, xistos e agregados clorítico-sericíticos. Adicionalmente, existem cristais de clorita, minerais opacos, apatita, muscovita, titanita e zircão.

Os diâmetros dos componentes clásticos principais destes arenitos, variam de 0,95 a 0,05 milímetros, havendo uma frequência maior dos grãos de dimensões compreendidas entre 0,20 a 0,1 milímetros. 
Os grânulos de quartzo são subangulares podendo ser alongados. Os feldspatos, potássicos e plagioclásio do tipo oligoclásio, exibem formas prismáticas alongadas, quase angulares; na maior parte das vezes mostram-se extremamente alterados, em sericita e caolim, ou fortemente tingidos por óxidos de ferro. Os quartzitos possuem textura granoblástica, podendo ser puros ou conter quantidades subor dinadas de sericita e clorita, ocupando os espaços intergranulares.

Nestes arenitos, bem como nos Arenitos Inferior e Superior, ocorrem fragmentos classificados como agregados clorítico-sericíticos, de di mensões reduzidas e difícil caracterização ao microscópio. Estes fragmentos podem formar massa verde clara ou incolor, contendo grande quantidade de impregnações irregulares ou puntiformes de óxido de ferro.

Além dos componentes já enumerados podem ainda ser encontrados falguns grânulos de vulcanitos, na maior parte das vezes recobertos por massa constituída de óxidos de ferro e minerais acessórios, além de cristais de muscovita e clorita de forma prismática ou fibro sa. A análise modal efetuada em duas amostras de arenito (Tabela 7 ) mostra que eles são predominantemente constituídos por quartzo e feldspato, cuja porcentagem atinge cerca de $60 \%$. A matriz argiloclorítica ocorre em proporção superior a $15 \%$, limite mínimo estabe lecido por Pettijohn et al (1972) para os "wackes". Os fragmentos de rocha variam entre 3 e $13 \%$ do total.

Essas características permitem classificar os arenitos intercalados aos conglomerados, nos grupos de arenitos arcózicos e "wackes arcózicos" conforme Pettijohn et al (1972). 


\section{TABELA 7}

ANÁLISE MODAL DE ARENITOS INTERCALADOS

AOS CONGLOMERADOS

\begin{tabular}{|l|c|c|}
\cline { 2 - 3 } \multicolumn{1}{c|}{} & $\begin{array}{c}\text { SL- } 71-10 \\
(48 \mathrm{~m}) \\
\%\end{array}$ & $\begin{array}{c}\text { SL-71-10 } \\
(295 \mathrm{~m}) \\
\%\end{array}$ \\
\hline Quartzo & 36,4 & 31,0 \\
Feldspato & 22,2 & 25,6 \\
Fragmentos de Rochas & 12,8 & 3,4 \\
Matriz & 19,3 & 15,6 \\
Cimento Calcítico & 2,5 & 12,0 \\
Limonita & - & 6,2 \\
Opacos & 4,0 & 3,3 \\
Filosilicatos & 1,1 & 2,0 \\
Acessórios & 1,7 & 0,9 \\
\hline
\end{tabular}

VII. 4.3.4 Arenito Superior

Os sedimentos designados por Arenito Superior, macroscopicamente, apresentam cor chocolate, e aspecto maciço ou com acamamento bem. desenvolvido. Sua textura é clástica e o empacotamento é frouxo. Os componentes principais são grânulos angulosos e subangulosos, discóides ou alongados e de distribuição caótica.

Ao microscópio, é possível observar alinhamento incipiente de cristais prismáticos de filosilicatos (clorita e muscovita), dispostos na maior parte das vezes, paralelamente ao acamamento. 
Abundante cimento ferruginoso e calcítico substitui e engloba a matriz argilosa, enquanto os fragmentos detríticos são cimentados apenas por material calcítico (Fot. 8,9).

Quartzo mono e policristalino entre os principais componentes da rocha, apresentam frequente borda de crescimento autígeno. Os feldspatos estão representados por plagioclásio (oligoclásio) e felds pato potássico (ortoclásio e microclínio), sendo difícil estimar suas quantidades relativas. Algumas vezes estes minerais apresentam-se intensamente alterados em caolim e sericita.

Os grânulos de quartzito são de dimensōes muito reduzidas e possuem textura granoblástica. Podem apresentar quantidades subordinadas de clorita e sericita, que conferem aspecto xistoso à rocha.

A exemplo dos demais arenitos, também aqui ocorrem agregados clo rítico-sericíticos, já anteriormente citados.

A análise modal, efetuada em 3 amostras (Tabela 8), demonstra a existência de proporção significativa de cimento ferruginoso entre os limites de 4 a $8 \%$. A matriz também é abundante e os seus valores em volume variam de 13 a $18 \%$.

Os componentes clásticos mais frequentes são quartzo e feldspatos. Nas amostras analisadas a porcentagem de feldspatos varia de 3 a $21 \%$, excedendo os fragmentos de rochas, que ocupam de 4 a $7 \%$ do total.

As características texturais e composição mineralógica destas rochas, pelo esquema de classificação proposto por Pettijohn et al (1972), permitem englobá-las nos grupos dos arenitos quartzosos e arcózicos, havendo, no entanto, termos com composição de "wackes arcózicos". 
TABELA 8

ANÁLISE MODAL DE ARENITOS

(ARENITO SUPERIOR)

\begin{tabular}{|l|c|c|c|}
\cline { 2 - 4 } & $\begin{array}{c}\text { SL-71-6 } \\
(4,00 \mathrm{~m}) \\
\%\end{array}$ & $\begin{array}{c}\text { SL- } \\
(6,20 \mathrm{~m}) \\
\%\end{array}$ & $\begin{array}{c}\text { SL-71-8 } \\
(6,00 \mathrm{~m}) \\
\%\end{array}$ \\
\hline Fuartzo & 62,8 & 53,9 & 39,5 \\
Fragmentos de Rochas & 4,4 & 8,5 & 21,2 \\
Matriz & 4,2 & 4,8 & 7,9 \\
Cimento Ferruginoso & 8,8 & 18,4 & 13,9 \\
Calcítico & 3,3 & 8,5 & 4,2 \\
Opacos & 14,2 & 0,7 & 9,4 \\
Filosilicatos & 2,0 & 2,8 & 1,3 \\
Acessórios & 1,3 & 2,4 & - \\
\hline
\end{tabular}

arenito sublítico "wacke arcózico" "wacke arcózico"

VII. 4.4 Diabásio

As rochas hásicas que ocorrem na Mina são representadas por um grande dique de diabásio e por pequenos diques satélites decimétricos. Os contatos desse corpo principal à superfície, estão na quase totalidade encobertos, embora afloramentos intemperizados tenham sido mapea dos pelo autor (Fig. 3 ). 
Este dique corta obliquamente o sistema de veios da Mina S. Luiz. A direção aproximada varia entre N 65 - 75 W e os mergulhos são irregulares NE a SW. O caimento é sub vertical. A espessura é também variável sendo o valor médio de 20 metros. O comprimento ultrapassa 250 metros.

Em todos os níveis da Mina S. Luiz, observou-se uma zona de reação, com espessura variável entre 3 a 5 metros. E caracterizada por rocha híbrida, resultante de metamorfismo termal em conglomerados. Digno de nota é o metamorfismo térmico operado nos veios sulfereta dos. Em alguns distritos mineiros, este fenômeno tem merecido a atenção de diversos investigadores, assinalando-se as publicações de (Salles e Meyer, 1951; Grahan, 1968 e Mookherjee et al, 1968).

As secções polidas observadas mostram que a temperatura da intru são foi suficiente para provocar transformações mineralógicas, e fusão parcial. dos sulfetos. Este fenômeno é particularmente testemu nhado pela forma amebóide dos corpos afetados, que apresentam um núcleo central do qual irradiam filetes irregulares resultantes de preenchimento de fraturas paralelas às paredes do dique.

Microscòpicamente a rocha é mesocrática, preta, cinzento escura ou com tonalidade esverdeada, devido alteração hidrotermal intensa. A granulação é fina a média, sendo reconhecíveis a ôlho nu, cristais ripiformes de plagioclásios. Variaçōes texturais podem ser observa das no centro para os bordos do corpo, onde predomina granulação mais fina.

A análise modal (Tabela 9), efetuada nas amostras estudadas, permite concluir que nas rochas observadas, os plagioclásios e piroxênios constituem os componentes mais numerosos, perfazendo 58 a $79 \%$ da rocha. Em ordem de importância, ocorrem produtos de alteração ; olivina alterada, minerais do grupo das cloritas e filosilicatos, que perfazem entre 15 a $16 \%$, além de minerais opacos e mesóstasis, com quantidades variáveis de 1,8 a 4,8 e 2,3 a $3,3 \%$ respectivamente. 
TABELA 9

COMPOSIÇÃO MODAL DO DIQUE DE DIABÁSIO DA MINA S. LUIZ

\begin{tabular}{|l|c|c|}
\hline \multicolumn{1}{|c|}{ MINERAL } & $\begin{array}{c}\text { Nível 300 } \\
\text { A M-SL-154 } \\
\%\end{array}$ & $\begin{array}{c}\text { Nível 700 } \\
\text { AM-SL-700 } \\
\%\end{array}$ \\
\hline Plagioclásio & 42,3 & 51,7 \\
Piroxênio & 36,6 & 26,2 \\
Pigeonita & - & - \\
Opacos & 3,3 & 2,3 \\
Matriz Mesostasis & 1,8 & 4,8 \\
Produtos de Alteração & 16,0 & 15,0 \\
\hline
\end{tabular}

Da análise dos valores óticos ecristalográficos obtidos, verifica-se que a composição média dos plagioclásios é An 65. Os valores médios estão compreendido entre An 60 - An 65, o que corresponde à varieda de labradorita. Entretanto, deve-se assinalar que nos bordos dos cris tais a composição se aproxima de andesina. Os piroxênios diagnostica dos são representados por variedades de augita e pigeonita, esta ocor rendo em quantidade desprezível. Os valores óticos médios das augitas e pigeonitas são $2 \mathrm{Vx}=49$ ? e $2 \mathrm{Vx}=0$ \% respectivamente.

As olivinas presentes se mostram extremamente alteradas em filosili catos verdes, não identificados, e biotita verde. A matriz é constituida por material de composição variável, formando agrupamentos de mi crominerais onde predominam minerais do grupo das cloritas, piroxê nios, feldspatos, apatita e provavelmente serpentinas. 
Duas amostras do dique de diabásio, referentes aos níveis 300 e 700 da Mina S. Luiz foram submetidas a datação pelo método K - Ar, em plagioclásios, no Laboratório de Geocronologia do Instituto de Geo ciências da U.S.P. As idades obtidas (Tabela 10) variam entre 106 a $107 \pm 10$ milhões de anos e concordam com os valores anteriormen te conseguidos por Amaral et al (1966), em rochas basálticas do Sul do Brasil. Estes números são baixos em relação à media das idades dessas rochas que é de 120 milhões de anos. Segundo os mesmos autores, essa diferença é devida a perda de argônio. A julgar por esses valores, as rochas basálticas que ocorrem no Distrito Mineiro de Camaquã, estariam relacionadas ao vulcanismo que atingiu o Sul do Brasil no Cretáceo Médio Inferior.

TABELA 10

IDADES K-Ar DO DIQUE DE DIABÁSIO DA

MINA S. LUIZ

\begin{tabular}{|c|c|c|c|c|c|}
\hline Mina S. Luiz & Amostra & $\mathrm{K}(\%)$ & $\begin{array}{l}\operatorname{Ar}^{40} \\
\quad \operatorname{rad}^{\circ} \\
\left(10-{ }^{6} \operatorname{csTP} / g\right)\end{array}$ & $\operatorname{Ar} \begin{array}{l}40 \\
\operatorname{atm}(\%)\end{array}$ & $\begin{array}{l}\text { Idade } \\
\text { (m.a.) }\end{array}$ \\
\hline Nível 300 pés & AM-SL 154 & 0,445 & 1,94 & 78,7 & $106 \pm 10$ \\
\hline Nível 700 pés & AIM-SL 700 & 0,287 & 1,14 & 66,6 & $107+10$ \\
\hline
\end{tabular}




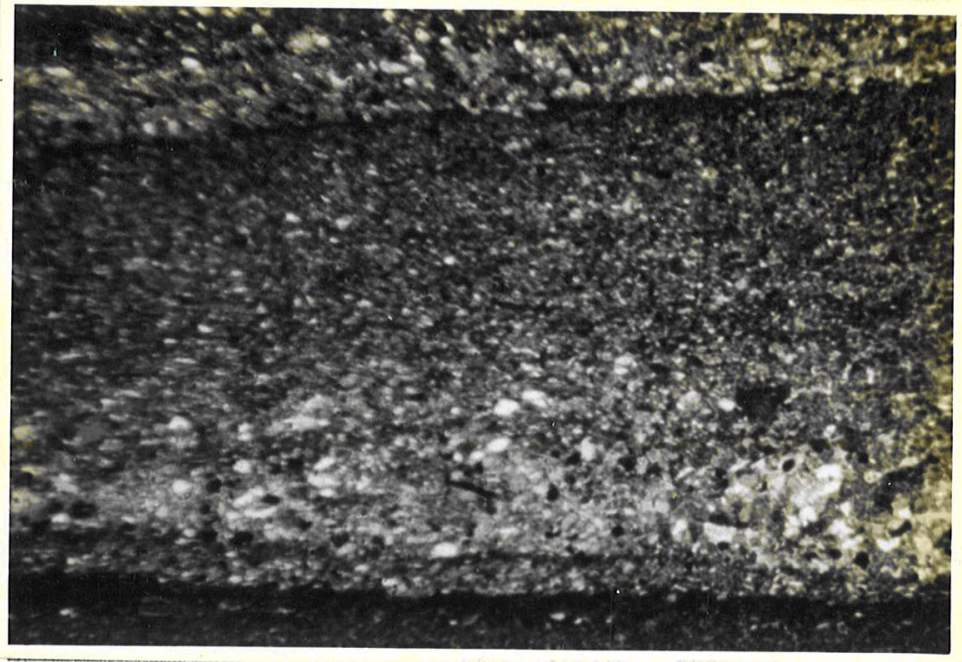

Fotomicrografia - 4 - Estratificação gradual em siltitos do Membro Mangueirão.

Nicois cruzados. Aumento: 73 vezes.

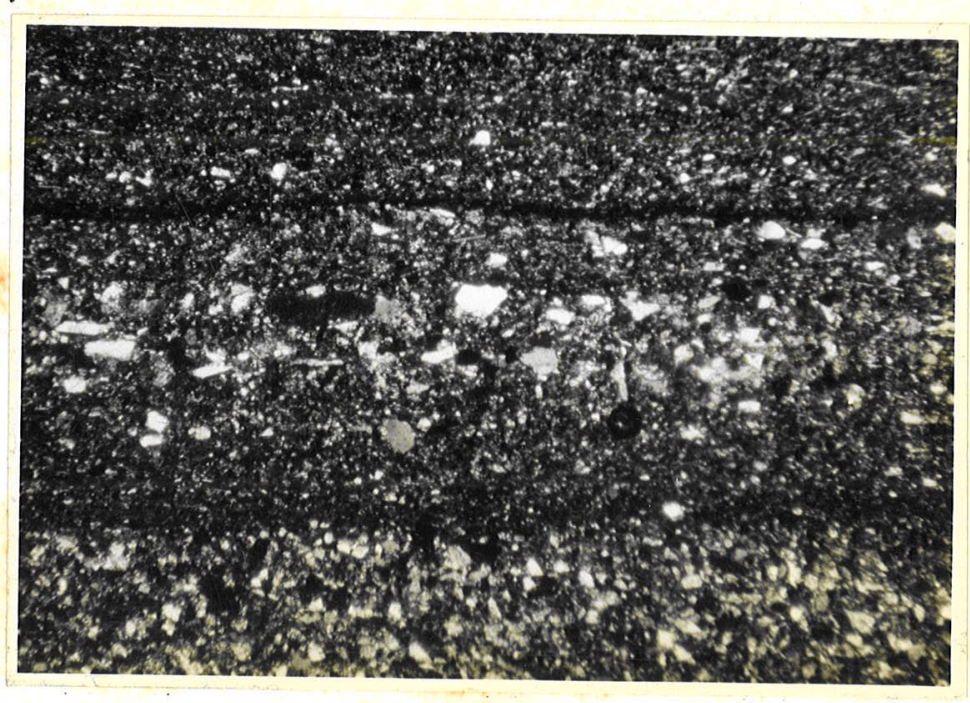

Fotomicrografia - 5 - Estratificação gradual em sedimentos rítmicos do Membro Vargas. Nicois cruzados. Aumento: 73 vezes. 


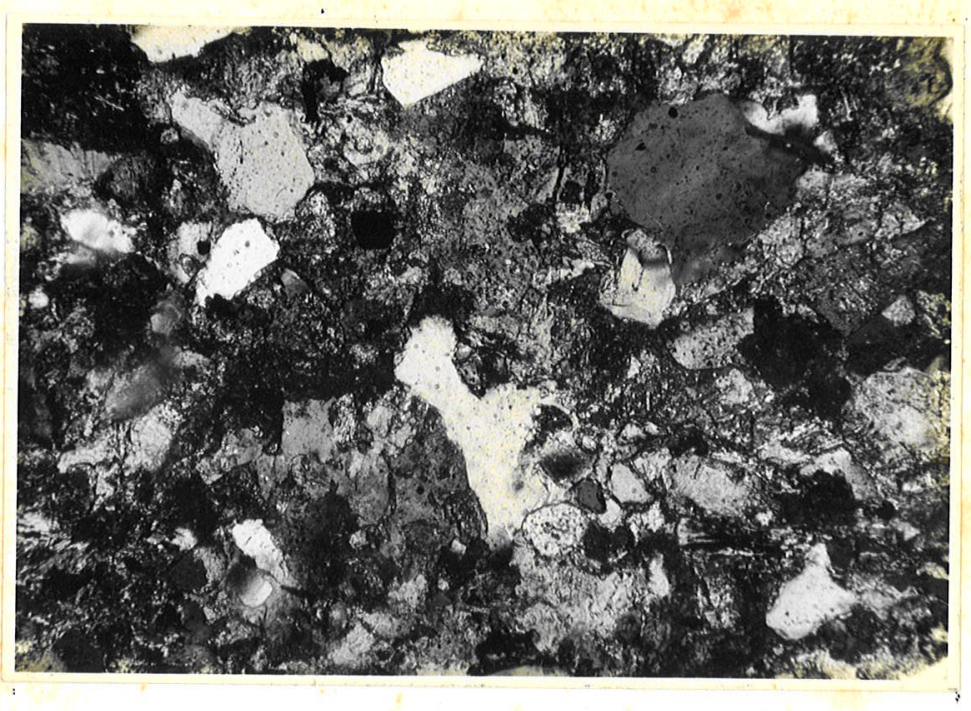

Fotomicrografia - 6 - (Membro Mangueirão) Grauvaca lítica com grânulos líticos e quartzo, em matriz fina clorítica-sericítica. Cimento calcítico. Nicois cruzados. Aumento: 182 vezes.

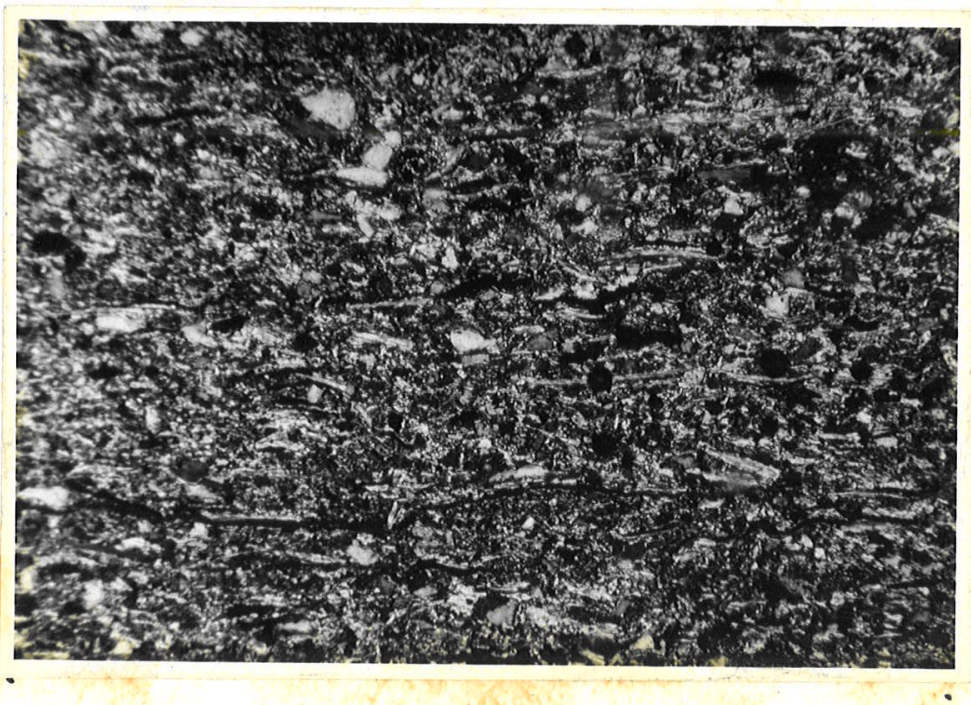

Fotomicrografia - 7 - Siltito do Membro Mangueirão com filosilicatos orientados paralelamente ao acamamento. Nicois cruzados. Aumento: 182 vezes. 


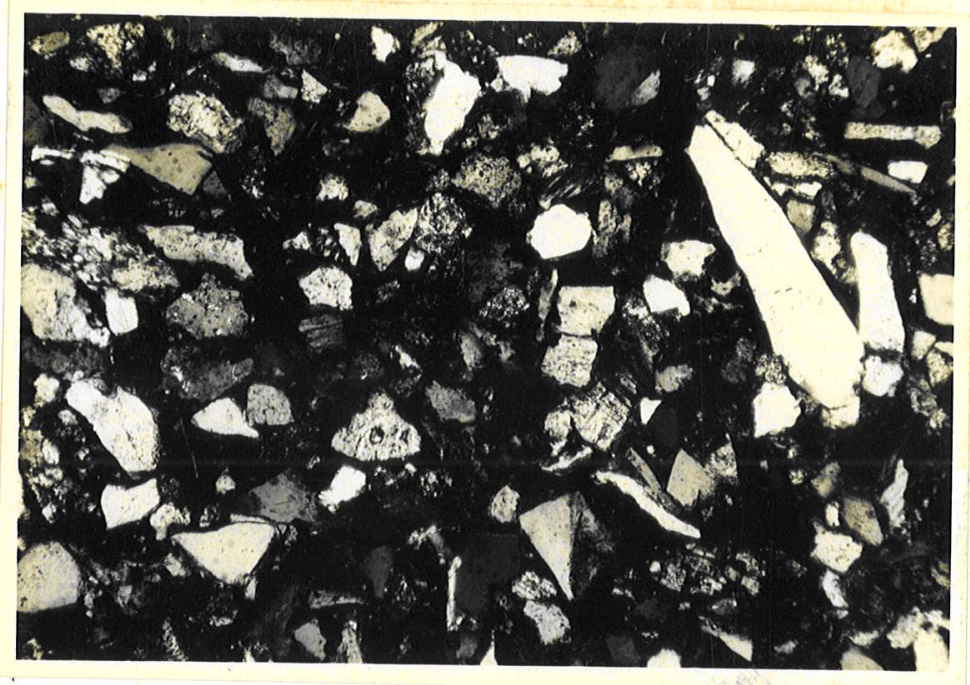

Fotomicrografia - 8 - Arenitos sublíticos ferruginosos do Arenito Superior. A matriz argilosa e o cimento ferruginoso são abundantes. Nicois cruzados. Aumento: 175 vezes.

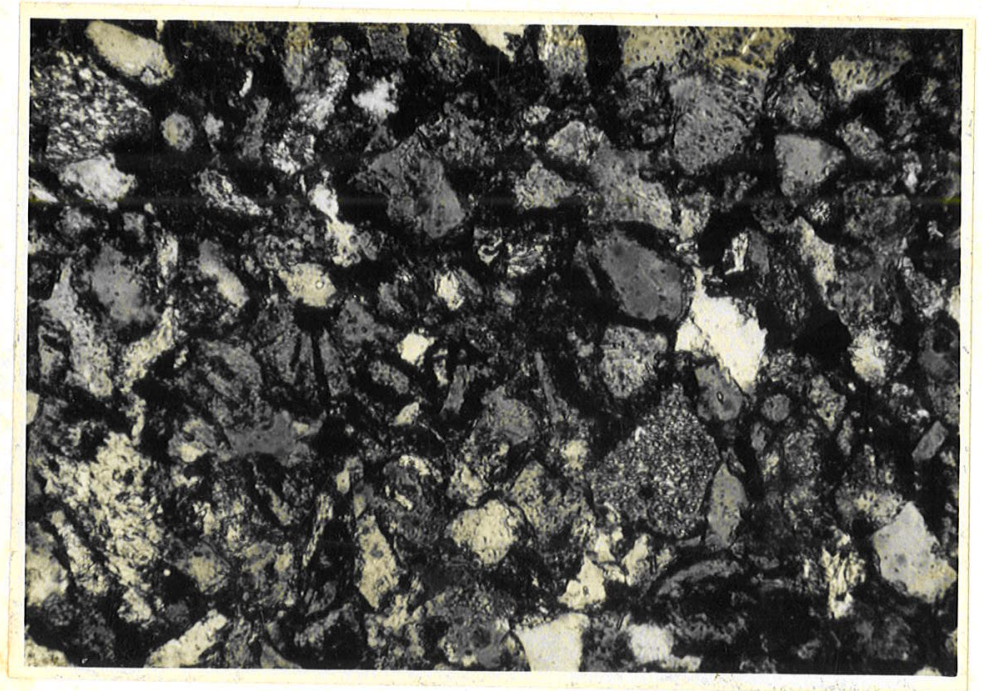

Fotomicrografia - 9- "Wackes arcózicos" do Arenito Superior. Notar os fragmentos líticos, matriz e cimento ferruginos abundante. Nicois cruzados. Aumento: 448 vezes. 


\section{VIII. $1 \quad$ Análise Estrutural}

A partir do ano de 1969 foram iniciados trabalhos de mapeamento geológico sistemático de subsolo, por Bettencourt e Damasceno (1969) e até à data pela equipe técnica da C. B. C., da qual o autor fazia parte. Os níveis 500 e 400 da Mina Uruguai e 500 da São Luiz foram parcialmente mapeados à escala 1:250 e posteriormente os níveis 300, 200 e 100 da Zona Piritas (Mina Uruguai), níveis 600 e 100 da Mina São Luiz, além da galeria do Filão São Júlio.

Os dados geológicos antigos de superfície foram compilados e com plementados com trabalhos adicionais executados nas zonas Inter me diária, São Luiz, Uruguai, Oscarino e Feliciano. Aproximadamente 1. 712 medidas estruturais foram obtidas na área, sendo estes valores estruturais tratados estatisticamente, de maneira a permitir uma aná lise adequada do padrão estrutural do distrito. Esta análise estatistica sistemática levou em consideração somente o sistema de fraturas pré-mineralização.

A análise estrutural foi executada segundo um processo que compreen de duas fases. A primeira fase abrange a análise das propriedades geométricas e a segunda, em que é feita uma análise dinâmica, conduz à caracterização dos esforços que determinaram as deformações locais.

\section{VIII.1.1 Procedimento de Campo e Tratamento dos Dados}

Os dados estruturais de subsolo foram compilados durante os trabalhos de mapeamento geológico sistemático dos diferentes níveis de explora ção das minas e ao longo de galerias e travessas de distritos e subníveis correspondentes. Via de regra, as leituras dos parâmetros estruturais foram feitas de dez em dez metros, segundo os métodos padronizados de mapeamento geológico de subsolo. As direçōes e mergulhos de falhas, juntas, acamamento e, eventualmente, a inclinação das estrias em planos de falhas foram medidas. 
Os valores estruturais de superfície constituem uma compilação completa dos mapas geológicos de Teixeira (1941), Costa Filho (1944), Comissão Mixta dos Metais Não Ferrosos (1959), Melfi e Arruda (1961), Ribeiro (1966), Martins e Bettencourt (1970), complementados com trabalhos adicionais do autor, em 1971.

Na coleta dos dados, não se considerou a frequência por unidade volumétrica, fator litológico ou espessura das camadas, devido às limitações espaciais ao longo das galerias e travessas.

A compilação e tratamento dos valores estruturais foram feitos indi vidualmente, para a superfície e para cada uma das Minas, São Luiz e Uruguai, respectivamente, a partir de mapas superficiais à escala $1: 1.000$ e $1: 500$ e de subsolo à escala 1:250. Todos os valores estrutu rais disponíveis foram agrupados nas seguintes categorias: falhas maiores, falhas menores, juntas, acamamento e estrias de falhas.

Os polos dos elementos lineares e planares de cada Mina e da super fície foram lançados em diagramas de projeção de igual área (Diagra ma de Lambert-Rede Schmidt). Para os diagramas com pontos esta tisticamente não significativos seria melhor usar outra técnica mais adequada. Acredita-se, entretanto, que nāo há desvios significativos nos casos apontados.

A avaliação estatistica dos dados foi feita por método gráfico, sendo os diagramas de contorno, no hemisfério inferior obtidos a partir do diagrama de Vistelius.

\section{VIII.1.1.1 Mina São Luiz}

\section{VIII.1.1.1.1 Falhas Maiores e Menores}

O diagrama de contorno das falhas principais, da Mina Säo Luiz, foi executado a partir de 289 medidas, na maioria, efetuadas em conglome rados ( Fig. 4 ). Em ordem de frequência e importância foram revelados 3 conjuntos de falhas. 


$$
\begin{array}{r}
\mathrm{N} 20 \mathrm{~W}-81 \mathrm{NE}-11,1 \% \\
\mathrm{~N} 68 \mathrm{~W}-51 \mathrm{NE}-5,6 \% \\
\mathrm{~N} 60 \mathrm{~W}-60 \mathrm{SW}-2,1 \%
\end{array}
$$

O diagrama (Fig. 4) mostra as orientaçōes das falhas menores e configura 2 conjuntos, sendo os valores máximos concordantes com os das falhas principais. Foram utilizadas 265 medidas, que revela ram os seguintes conjuntos:

$$
\begin{aligned}
& \text { N } 20 W-74 \mathrm{NE}-8,3 \% \\
& \mathrm{~N} 54 \mathrm{~W}-78 \mathrm{NE}-8,0 \%
\end{aligned}
$$

Em vista da similaridade dos padrōes obtidos, foi confeccionado um novo diagrama, integrando as 554 medidas, correspondentes às falhas maiores e menores, delimitando, também, 2 conjuntos, na maior parte coincidentes com as atitudes anteriormente obtidas:

$$
\begin{aligned}
& \mathrm{N} 20 \mathrm{~W}-81 \mathrm{NE}-9,2 \% \\
& \mathrm{~N} 70 \mathrm{~W}-50 \mathrm{NE}-3,0 \%
\end{aligned}
$$

\section{VIII.1.1.1.2 Tuntas}

O diagrama representativo das juntas (Fig. 7) foi obtido a partir de 49 medidas, talvez insuficientes para serem consideradas represen tativas. Entretanto, os valores obtidos demonstram a existência de 6 conjuntos de fraturas:

$$
\begin{aligned}
& \mathrm{N} 41 \mathrm{~W}-70 \mathrm{NE}-10,2 \% \\
& \mathrm{~N} 79 \mathrm{~W}-70 \mathrm{SW}-6,1 \% \\
& \mathrm{~N} 80 \mathrm{E}-60 \mathrm{SE}-4,1 \% \\
& \mathrm{~N} 19 \mathrm{E}-80 \mathrm{SE}-4,1 \% \\
& \mathrm{~N} 69 \mathrm{E}-70 \mathrm{NW}-4,1 \% \\
& \mathrm{~N} 61 \mathrm{~W}-\text { Vertical }-4,1 \%
\end{aligned}
$$




\section{VIII.1.1.1.3 Acamamento}

O diagrama de acamamentos (Fig. 8 ) dá uma idéia das mudanças nas direções e mergulhos, na maior parte produzidas pelos falha mentos. Embora haja grande variação e espalhamento de pontos, existe um máximo com orientação N $43 \mathrm{E}-30 \mathrm{NW}$.

\section{VIII.1.1.2 Mina Uruguai}

\section{VIII.1.1.2.1 Falhas Maiores e Menores}

O diagrama de contorno para falhas maiores foi executado em função de 234 medidas. A(Fig. 5 ) ilustra o comportamento mais regular das falhas, em relação à Mina São Luiz, mostrando a existência de um único valor máximo.

$$
\mathrm{N} 50 \mathrm{~W}-70 \mathrm{sW}-11,1 \%
$$

$\mathrm{Na}$ (Fig. 5 ) estão representadas 288 medidas de falhas menores; o diagrama mostra a existência apenas de um único conjunto represen tado pelo valor:

$$
\mathrm{N} 50 \mathrm{~W}-70 \mathrm{SW}-9,4 \%
$$

A exemplo do procedimento efetuado para a Mina São Luiz, também para a Mina Uruguai foi elaborado um novo diagrama integrando as 522 medidas, correspondentes às duas categorias de falhas, embora já prevendo a obtenção do valor máximo N $50 \mathrm{~W}-70 \mathrm{SW}$.

\section{VIII:1.1.2.2 Juntas}

O diagrama de contorno foi obtido a partir de 175 observaçōes. Os conjuntos, arranjados em ordem de importância decrescente, são os seguintes: 


$$
\begin{aligned}
& \text { N } 58 \mathrm{~W}-37 \mathrm{SW}-6,8 \% \\
& \mathrm{~N} 65 \mathrm{~W}-60 \mathrm{SW}-5,7 \% \\
& \mathrm{~N} 13 \mathrm{~W}-40 \mathrm{SW}-3,4 \% \\
& \mathrm{~N} 8 \mathrm{E}-64 \mathrm{NW}-2,9 \% \\
& \mathrm{~N} 65 \mathrm{E}-40 \mathrm{NW}-2,8 \%
\end{aligned}
$$

VIII.1.1.2.3 Acamamento

O número de medidas representativas do acamamento foi 35 , o que não é considerado satisfatório para qualquer estimativa estatística. Entretanto, o diagrama (Fig. 8 ) demonstra a existência de dois má ximos e espalhamento grande de pontos, o que é devido ao fato de serem tomadas nos blocos inter-falhas.

As direções e mergulhos dos conjuntos são:

$$
\begin{aligned}
& \mathrm{N} 44 \mathrm{E}-32 \mathrm{NW}-23 \% \\
& \mathrm{~N} 70 \mathrm{E}-45 \mathrm{NW}-20 \%
\end{aligned}
$$

\section{VIII.1.1.3 Superfície}

\section{VIII.1.1.3.1 Falhas Principais e Menores}

Considerando o número limitado de falhas menores, as medidas estru turais de planos de falhas superficiais foram integradas em um único diagrama (Fig. 6), executado a partir de 122 medidas. Em ordem de frequência decrescente foram assinalados 5 conjuntos de falhas, enu merados abaixo:

$$
\begin{aligned}
& \text { N } 50 \mathrm{~W}-71 \mathrm{SW}-11,5 \% \\
& {\left[\begin{array}{l}
\mathrm{N} 60 \mathrm{~W}-60 \mathrm{NE}-4,1 \% \\
\mathrm{~N} 60 \mathrm{~W}-89 \mathrm{NE}-6,5 \%
\end{array}\right.} \\
& {\left[\begin{array}{l}
\mathrm{N} 70 \mathrm{E}-80 \mathrm{NW}-4,0 \% \\
\mathrm{~N} 70 \mathrm{E}-80 \mathrm{SE}-3,3 \%
\end{array}\right.} \\
& \mathrm{E}-\mathrm{W}-90 \mathrm{~N}-0 \% \\
& \mathrm{~N} 20 \mathrm{~W}-84 \mathrm{NE}-3,3 \%
\end{aligned}
$$


VIII.1.1.3.2 Juntas

Os valores estruturais correspondentes às juntas superficiais foram compilados de mapas efetuados em diversas épocas da vida da Mina, motivo pelo qual não foi feita nenhuma qualificação e separação cro nológica de juntas pré e pós-mineralização. No diagrama obtido, estes valores foram lançados indistintamente, devido à impossibilida de da sua separação. Os polos correspondentes às juntas pré minera lização serão individualizados por comparação com os conjuntos obtidos da análise estatística dos níveis inferiores das minas. Entre tanto, por precaução, evitou-se fazer qualquer correlação com os dados de subsolo, devido à possibilidade de sobreposição dos sistemas pré e pós mineralização.

\section{VIII.1.1.3.3 Acamamento}

O número de medidas efetuadas à superfície foi 162. O diagrama (Fig. 8 ) mostra a existência de um valor máximo, orientado segundo

$$
\mathrm{N} 59 \mathrm{E}-32 \mathrm{NW}
$$

VIII. 1.2 Relações entre Falhas Maiores, Menores e Juntas

A observação dos dados estatísticos obtidos para falhas principais na Mina S. Luiz aponta 2 conjuntos importantes oblíquos entre sí:

$$
\begin{aligned}
& \text { N } 20 \mathrm{~W} \\
& \text { N } 60-68 \mathrm{~W}
\end{aligned}-\begin{array}{r}
81 \mathrm{NE} \\
51 \mathrm{NE} \\
60 \mathrm{SW}
\end{array}
$$


Analisando o padrão de falhamento obtido para as falhas menores, percebe-se que os máximos N $20 \mathrm{~W}-74 \mathrm{NE}$ e N $54 \mathrm{~W}-78 \mathrm{NE}$ se desenvolveram paralela e subsidiariamente às falhas principais as sociadas. O conjunto N $54 \mathrm{~W}-78 \mathrm{NE}$ desenvolveu-se a ângulo muito pequeno em relação ao conjunto 2 das falhas maiores. O ângulo de obliquidade de 14 ? demonstra a natureza penada em relação às falhas principais similares.

Na Mina Uruguai, o padrão de falhamentos principais é mais regular. e é representado por um único conjunto, $\mathrm{N} 50 \mathrm{~W}-70 \mathrm{sW}$. São acom panhados pelas falhas menores satélites, que também apresentam as mesmas direções e mergulhos. A comparação dos dados obtidos no subsolo é à superfície, demonstra não apresentar desvios significantes de direção e mergulho. O cotejo entre os diversos diagramas, leva a admitir que no distrito existem 2 classes de falhas bem desenvolvidas, representadas pelos conjuntos:

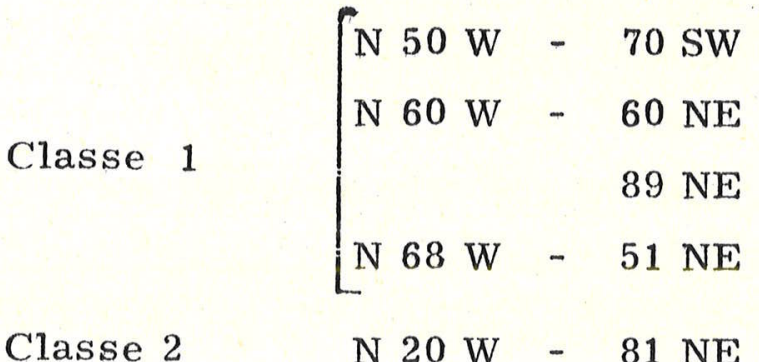

São portanto, coincidentes com aquelas apontadas nas minas S. Luiz e Uruguai.

Os conjuntos, N $70 \mathrm{E}-80 \mathrm{NW} / 80 \mathrm{SE}$, observados à superfície, correspondem a falhas menores oblíquas, associadas aos falhamentos principais, que são, particularmente bem desenvolvidas, na Zona Intermediária. 
O número de juntas medidas na Mina S. Luiz, não é considerado sufi cientemente representativo. Entretanto, os valores obtidos (Fig. 7) demonstram a existência de 6 conjuntos, que correspondem a juntas paralelas ou oblíquas aos falhamentos principais. A classe $\mathrm{N} 41 \mathrm{~W}-$ $70 \mathrm{NE}$ mais frequente, e os conjuntos, N $79 \mathrm{~W}-70 \mathrm{SW}$ e $\mathrm{N} 61 \mathrm{~W}-90$ formam pequenos ângulos com as falhas principais, às quais estäo relacionadas, em tôrno de 5 a 29\%. Os conjuntos N $80 \mathrm{E}-60 \mathrm{SE}$, $\mathrm{N} 19 \mathrm{E}-80 \mathrm{SE}$ e $\mathrm{N} 69 \mathrm{E}-70 \mathrm{NW}$, representam, por sua vez, juntas oblíquas ou subverticais às falhas principais, com mergulhos elevados. Na Mina Uruguai, o número de observações permitiu a obtenção de resultados mais representativos. A exemplo da Mina S. Luiz, existem juntas oblíquas e paralelas às falhas principais, cuja distribuição, no entanto, não coincide com aquela assinalada na Mina S. Luiz, pois no caso, são função das direções locais das fraturas às quais estão associadas. Os dois valores máximos mais frequentes, N 58 W - 37 SW e N $65 \mathrm{~W}$ - $60 \mathrm{SW}$ acompanham as direções gerais dos falhamentos principais e menores, com ângulos oblíquos até 15\%. O conjunto de juntas mais frequentes se situa segundo ângulo de mergulho baixo, com valor médio em torno de 379. Todos os demais conjuntos, repre sentados pelos máximos $\mathrm{N} 13 \mathrm{~W}-40 \mathrm{SW}, \mathrm{N} 8 \mathrm{E}-64 \mathrm{NW}$ e N $65 \mathrm{E}-$ $40 \mathrm{NW}$, são oblíquos e divergentes dos falhamentos já referidos sendo importante assinalar os baixos ângulos de mergulho.

\section{1.3 Qualificação das fraturas}

O mapeamento geológico de detalhe, efetuado à superfície e nos níveis inferiores das minas S. Luiz e Uruguai, assim como os estudos esta tísticos, indicam que no distrito, o sistema de falhas pré-mineraliza ção, apresenta distribuição em duas classes principais (Fig. 9 )

$1 \quad\left[\begin{array}{r}\mathrm{N} 50 \mathrm{~W}-71 \mathrm{SW} \\ \mathrm{N} 60 \mathrm{~W}-60 \mathrm{NE} \\ \mathrm{N} 68 \mathrm{~W}-89 \mathrm{NE}\end{array}\right.$
$21 \mathrm{NE}$


Êstes falhamentos são oblíquos entre si, de ângulos que variam entre 30 a $48 \%$. Os planos de fricção apresentam grande desenvolvimento de milonito, além de brechamento intenso. A espessura dos milonitos pode variar de poucos centímetros a alguns decímetros, enquanto as zonas brechadas atingem vários metros. Os mergulhos dos planos de falhas variam entre 40 a $90 \%$, sendo mais frequentes de 60 a 80 . Medidas de inclinação das estrias de falhas, efetuadas em subsolo e em superfícies frescas, (Fig in ) representam os movimentos ope rados nesses planos. Os valores obtidos demonstram que esses mer gulhos variam nos limites 50 a $90 \%$, com valores mais frequentes entre 80 a $90 \%$. No mapa geológico do distrito, (Fig. 3 ) verifica-se que na maior parte dos falhamentos e nos contatos das diferentes lito logias, são observados rejeitos significativos de até algumas dezenas de metros resultantes de movimentos relativos de blocos de falhas. As características tectônicas enumeradas, nomeadamente, espessura de materiais de fricção, milonitos, brechas, presença de estrias, mergulhos de planos de falhas e rejeitos, permitem admitir que as falhas podem ser qualificadas como normais escalonadas, em geral transversais ou oblíquas às direções das camadas. Admite-se, tam bém, que ao lado das falhas normais, ocorrem alguns casos de falhas reversas, de menor amplitude, cujo número é impossível estimar.

As juntas e fraturas tidas como obliquas ou subverticais aos planos de falha, são particularmente bem desenrolridas na Mina truguai onde são muito numerosas. Apresentam distribuiçāo penada em rela ção às falhas principais e pequena extensảo, terminando muitas vêzes a poucos metros. Seus planos estão livres de material brechado, suas espessuras variam de poucos centímetros a máximo de 0,30 metros. Via de regra estão mineralizados a sulfeto maciço e quartzo. O dia grama (Fig. 9 ) sumariza as relaçöes entre as falhas principais do distrito. 

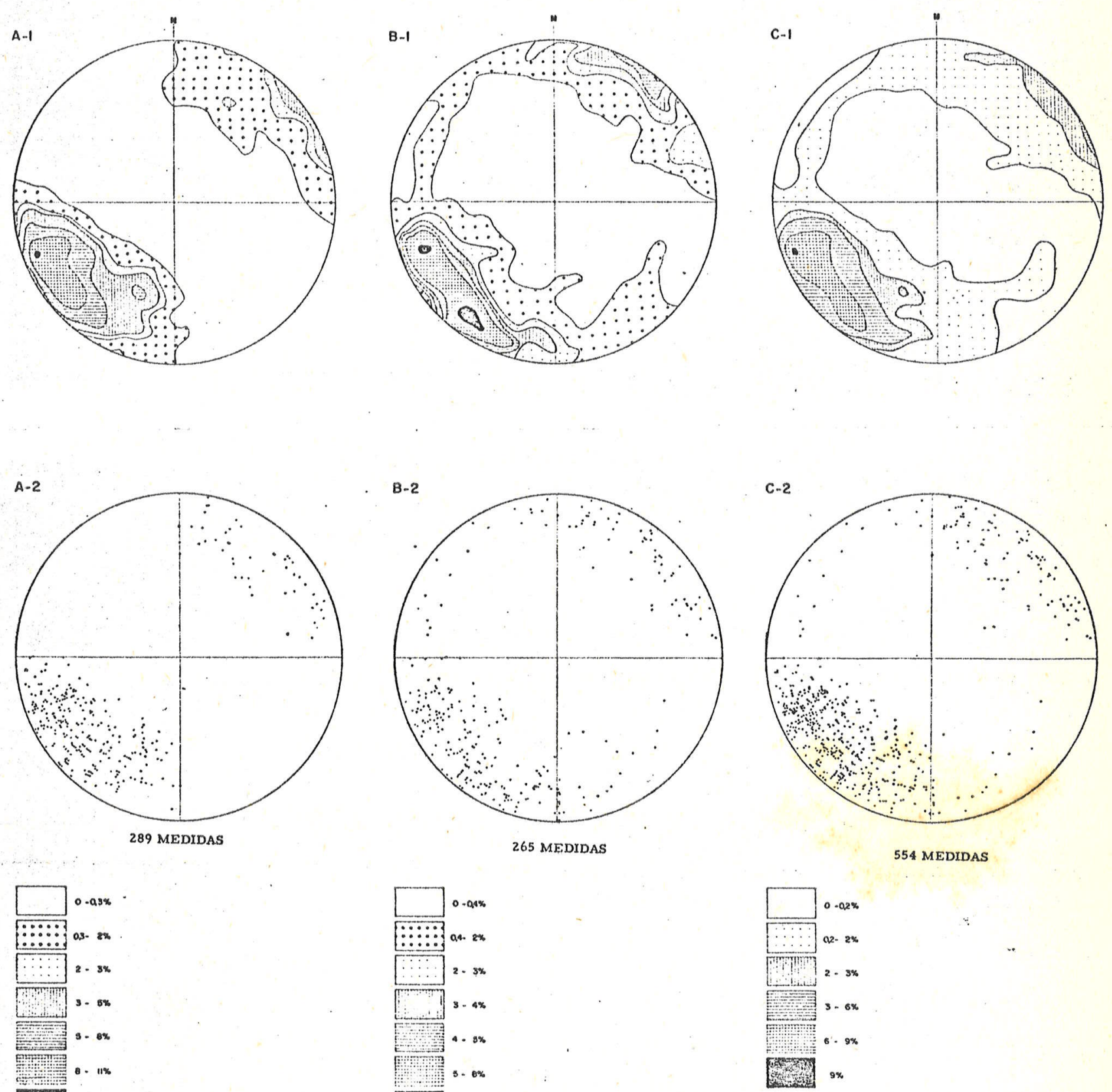

FIG. 4 DLAGRAMAS DE CONTORNO DE POLOS DAS NORMAIS (OBTIDAS NA REDE SCHMIDT-LAMBERT; HEMISFÉRIO INFERIOR) A FALHAS MAPEADAS NA MINA.SAO LUIZ.FALHAS PRINCIPAIS (A, $\left.-\mathrm{A}_{2}\right)$ FALHAS MENORES $\left(\mathrm{B}_{1}-\mathrm{B}_{2}\right)$ E FALHAS PRINCIPAIS E MENORES INTEGRADAS $\left(\mathrm{C}_{1}-\mathrm{C}_{2}\right)$. 

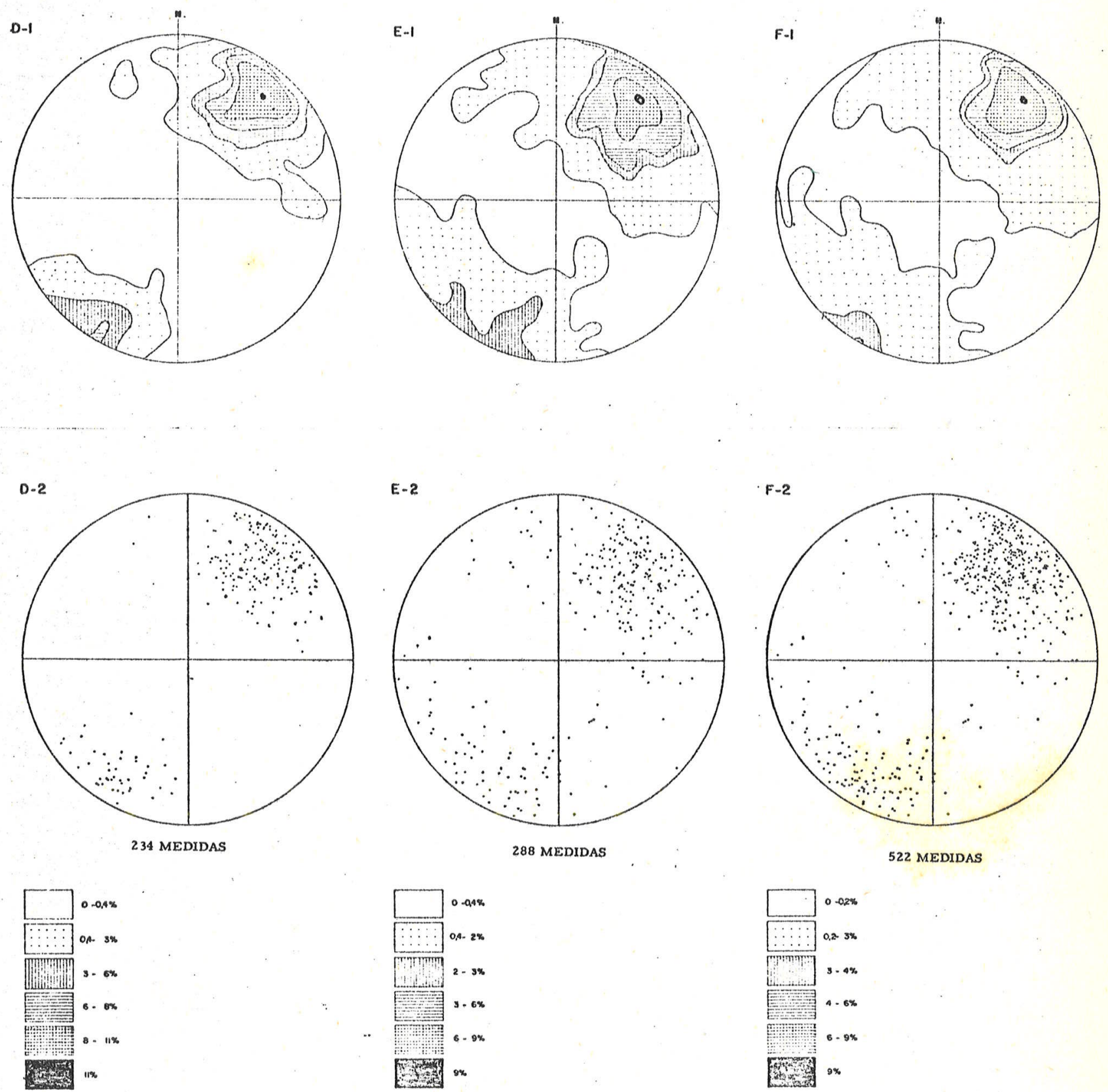

Sin $9 x$

FIG. 5 DIAGRAMAS DE CONTORNO DE POLOS DAS NORMAIS (OBTIDAS NA REDE SCHMIDT-LAMBERT: HEMISFERIO INFERIOR) A FALHAS MAPEADAS NA MINA URUGUAI. FALHAS PRINCIPAIS $\left(D_{1}-D_{2}\right)$. FAlihas menores $\left(E_{1}-E_{2}\right)$ E FALHas PRINCIPAIS E MENores INTEGRAdas $\left(F_{1}-F_{2}\right)$. 


\section{SUPERFICIE}

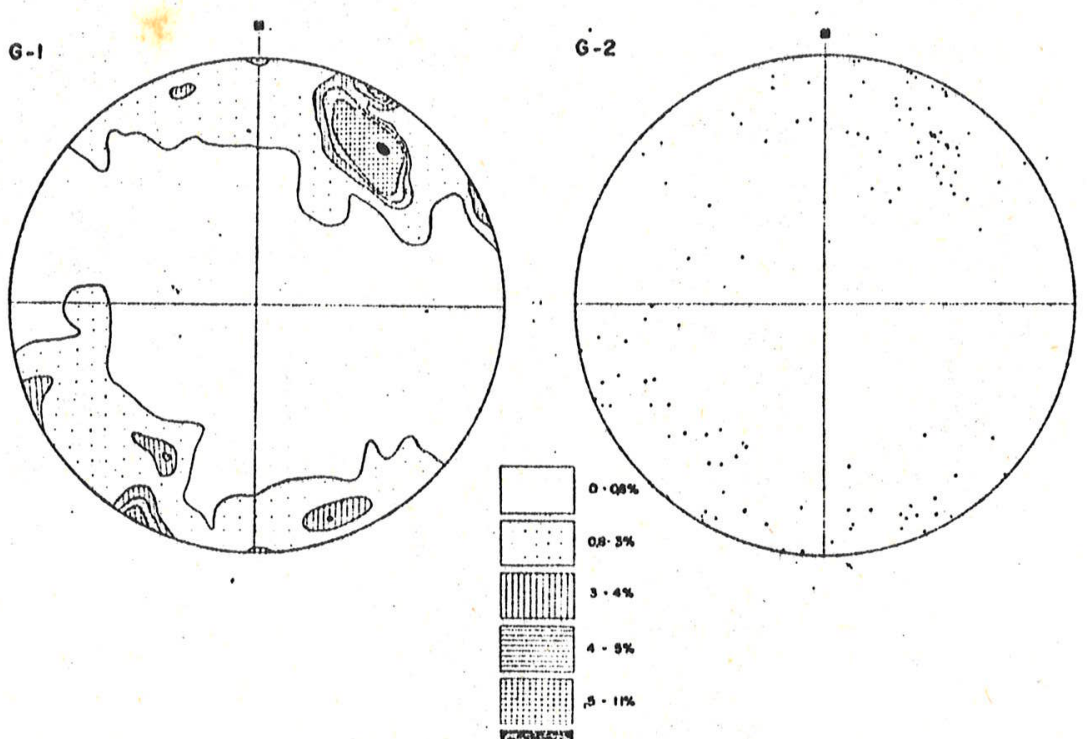

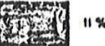

FIG. 6 DIAGRAMAS DE CONTORNO DE POLOS DAS NORMAIS (OBTIDAS NA. REDE SCHMIDT-LAMBERT, HEMISFERIO INFERIOR) A FALIHAS MAPEADAS A SUPERFICIE. FALHAS PRINCIPAIS E MENO RES INTEGRADAS $\left(G_{1}-G_{2}\right)$. 

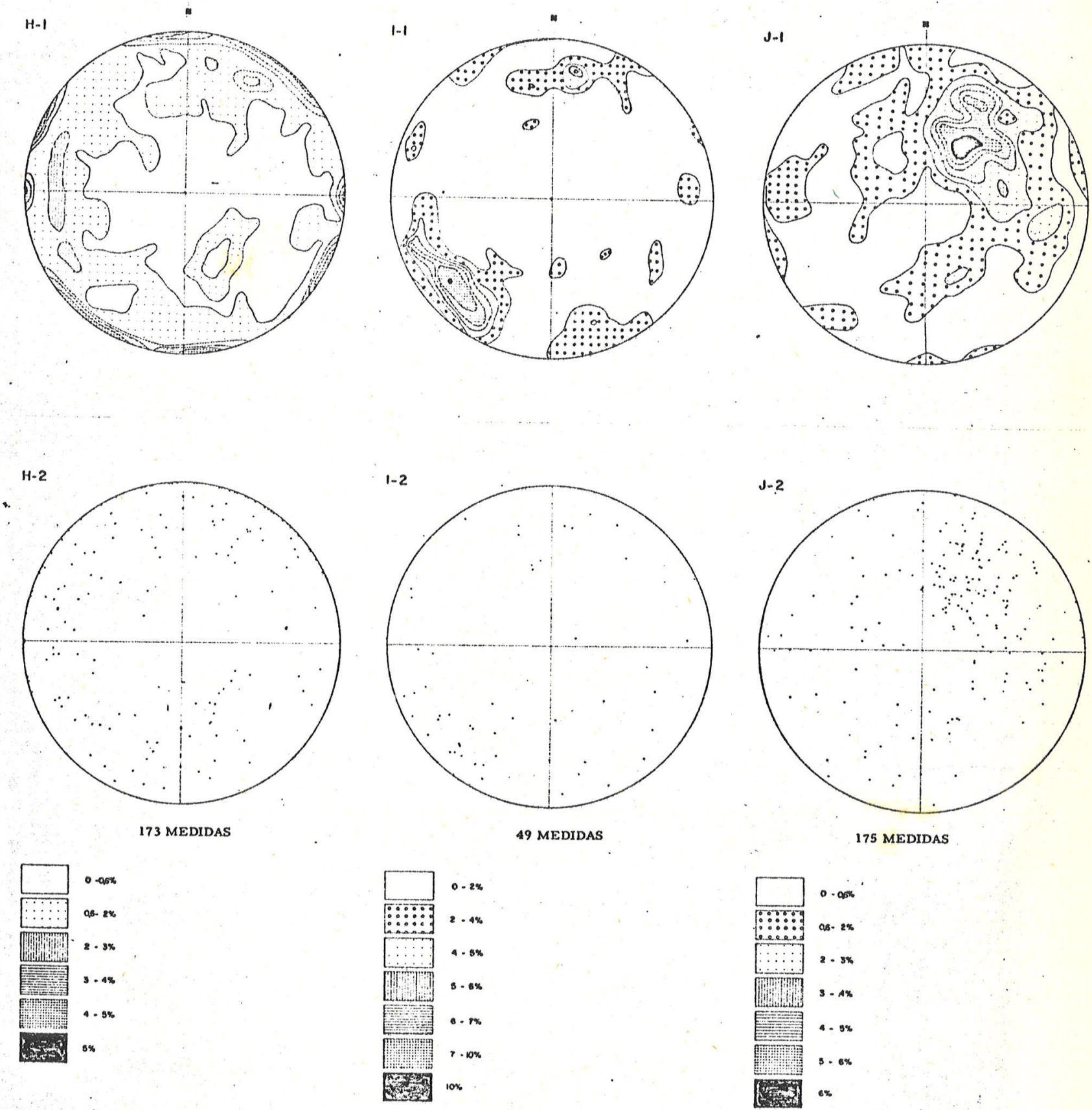

FIG. 7 DIAGRAMAS DE CONTORNO DE POLOS DAS NORMAIS (OBTIDAS NA. REDE SCHMIDT-LAMBERT, HEMISFERIO INFERIOR), A JUNTAS MEDIDAS A SUPERFICIE $\left(\mathrm{H}_{1}-\mathrm{H}_{2}\right)$, MINA S. LUIZ $\left(\mathrm{I}_{2}-\mathrm{I}_{2}\right)$ - E mina URUGUAS $\left(\mathrm{J}_{1}-\mathrm{J}_{2}\right)$. 


\section{ACAMAMENTO}
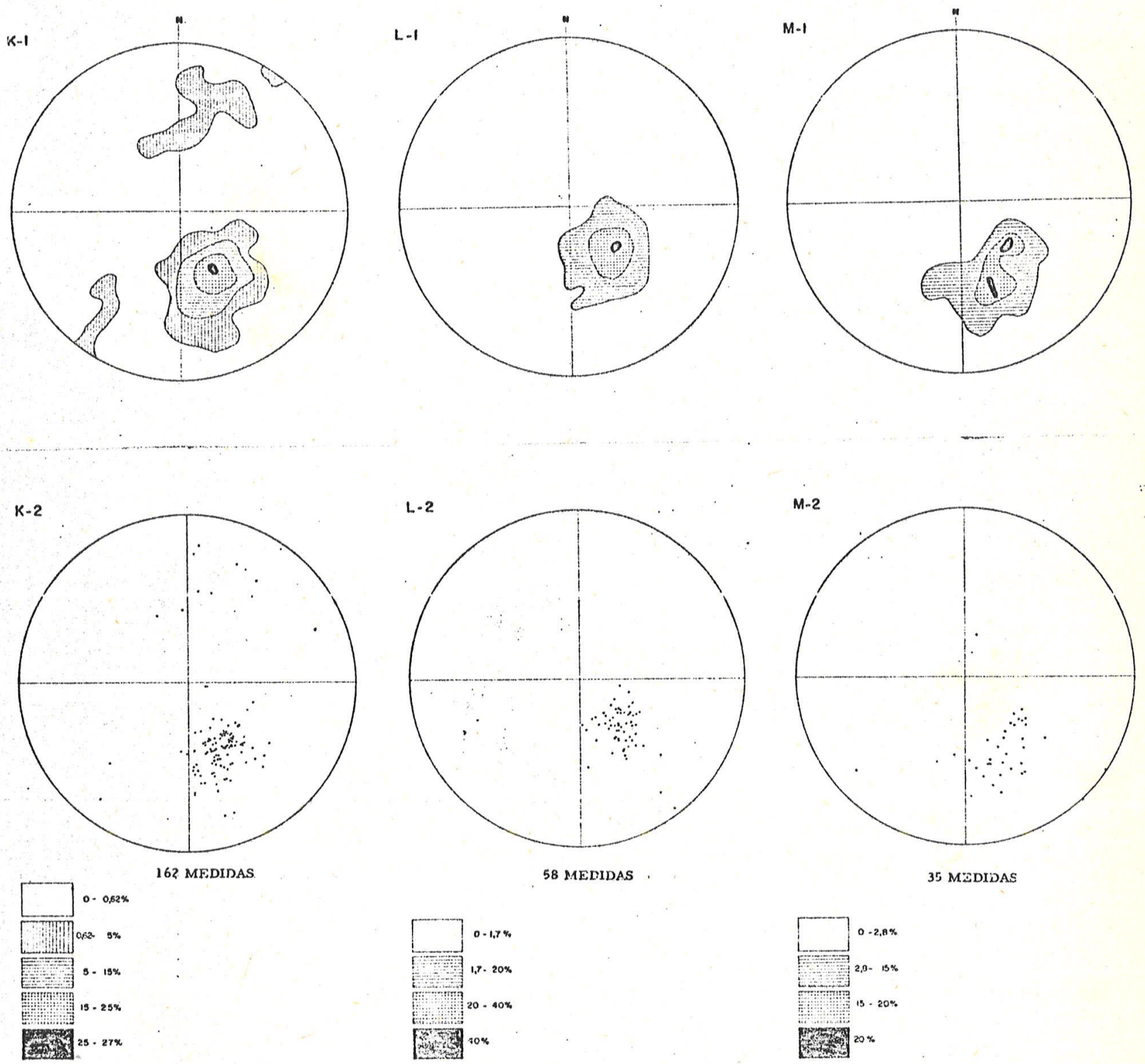

58 MEDIDAS

35 MEDIDAS
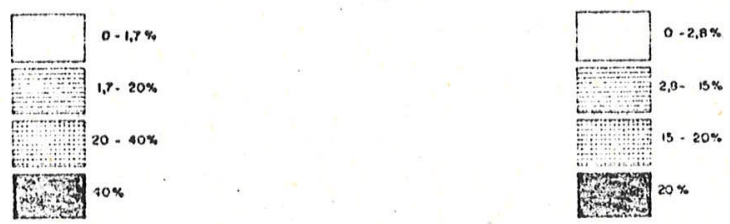

FIG. 8 DIAGRAMAS DE CONTORNO DE POLOS DAS NORMAIS, (OBTIDAS NA REDE SCHMIDT-LAMBERT, HEMISFERTO INFERIOR) A ACAMAMENTOS MEDIDOS A SUPERFICIF. $\left(K_{1}-K_{2}\right)$, MINA SAO LUIZ $\left(L_{1}-L_{2}\right)$ E MINA URUGUAI $\left(M_{1}-M_{2}\right)$. 


\section{VIII.1.4 Análise Dinâmica}

A análise global das características das estruturas anteriormente qualificadas indicam que a área da Mina de Camaquã foi submetida a um esforço de compressão local. Aplicando o esquema de Anderson (1951) da origem mecânica dos falhamentos, conclue-se que o esfôrço principal, (de gravidade) ( $\sigma 1$ ), foi essencialmente vertical, provocando subida e desçida de blocos, delimitados pelas falhas normais dominantes no distrito. A componente horizontal tracional ( 63 ), pos sue direção NE/ SW enquanto a compressional $\left(\sigma_{2}\right)$ tem direção NW/ SE (Fig. 11).

A identificação dos esforços responsáveis pela formação das falhas normais na Mina Camaquã, permite extrapolações em escala regional.

O mapa geotectônico regional, Ribeiro e Carraro (1971), demonstra que as falhas com direção NE, pertencentes ao Sistema Irapuá e que ocorrem perto.da Mina Camaquã foram classificadas como transcor rentes dextrais. Algumas destas falhas NE distam 300 metros dos falhamentos normais, que ocorrem na Mina, mas as de maior persis tência e desenvolvimento regional estão a cerca de 3,5 quilômetros. Em face da caracterização dos esforços na Zona da Mina, admite-se que:

a) As juntas com disposição penada, associadas às falhas NW da Mina Camaquã, devem estar vinculadas a esfor ços de terceira ordem, oriundos de rearranjos opera dos nos blocos em movimentação nor mal (gravitacio nal), sendo devidos a componentes tracionais locais.

b) As falhas normais, características da Mina Camaquã, seriam devidas a esforços de segunda ordem, com direção predominante NW/SE e sentido SE/NW, fato coerente com a característica dextral das falhas do Sistema Irapuá. 
As pequenas dobras, associadas aos grandes falha mentos NE, observadas no Membro Mangueirão (Fig. 2), possuem eixos perpendiculares à direção do esforço local de segunda ordem o que também reforça esta conclusão.

c) Os grandes falhamentos do Sistema Irapuá, de dire ção NE, resultam de um esforço regional de Primei ra ordem.

d) As diferenças direcionais observadas na classe 1 de falhas principais referidas atrás, que podem atin gir até $18^{\circ}$ graus, são filiadas a efeitos anisotrópicos locais durante o desenvolvimento das falhas, caracte rísticas de um processo de longa duração.

A Fig. 11 representa graficamente, as relações entre as fraturas e os esforços identificados no distrito.
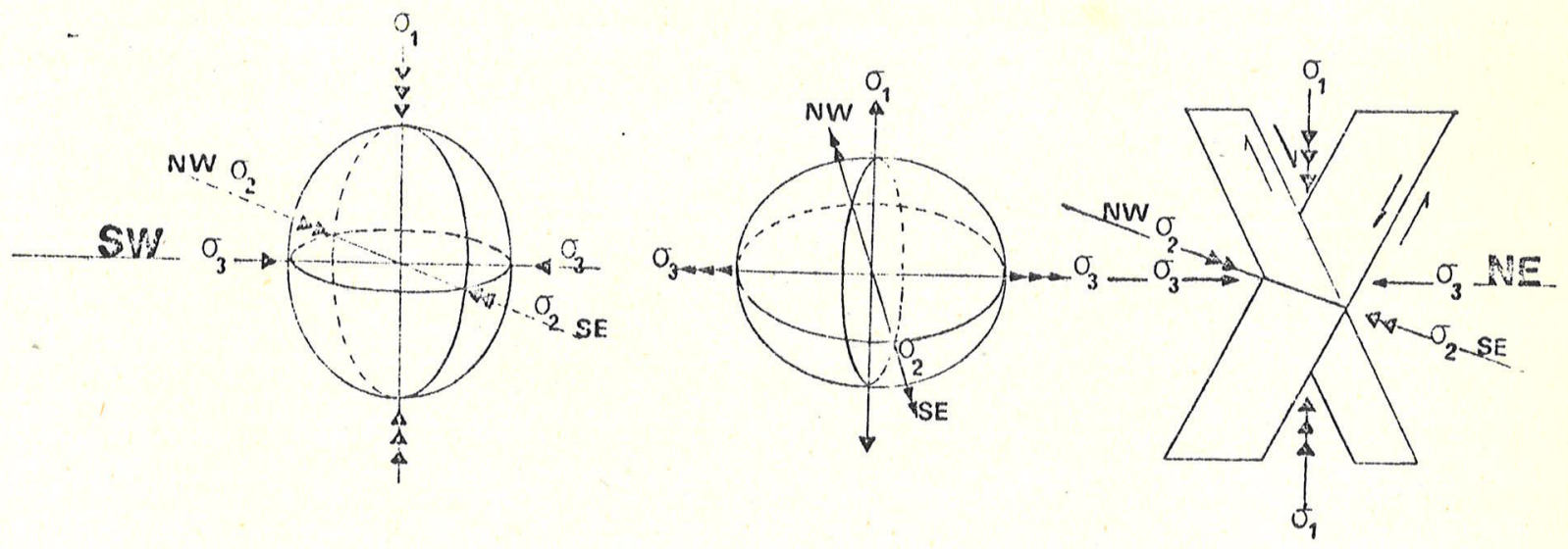

Fig.11 . Configuração das relações existentes entre fraturas e direções de esforços, na Mina de Camaquã, segundoo esquema de Anderson (1951). 
VIII. 1.5

Estruturas Locais e suas Relações com os Sistemas Regionais

As feições estruturais dominantes no Distrito Cuprífero de Camaquã são representadas pelos grandes falhamentos de direção NE, pelas suas falhas menores subsidiárias, de grande importância na minera lização no distrito, e também pelos falhamentos posteriores, mais recentes. Êstes últimos cortam as estruturas anteriores e foram englobadas no Sistema Cêrro dos Vigias.

As primeiras falhas (NE), caracterizam-se pela grande extensão li near e largura que varia de centenas de metros a alguns quilômetros. São acompanhados por elevado número de falhas subsidiárias (NW) a ângulos de 30 a 45 \% das principais. As falhas antigas pré-mineralização de direção NE, juntamente com as suas subsidiárias NW, foram agru padas por Ribeiro et al (1966, págs. 149, 151), no chamado sistema Irapuá.

Os mesmos autores consideram que estas fraturas se estabeleceram ao final do Pré-Cambriano, tendo climax de formação durante a depo sição da parte superior da Formação Arroio dos Nobres. A movimenta ção deve ter continuado com pulsaçōes periódicas, que atingiram ainda os sedimentos da Formação Guaritas, Ribeiro e Carraro (1971).

As observações de subsolo ora efetuadas, também indicam que os movi mentos nos planos destas falhas continuaram por longo período, durante e depois da mineralização, o que é atestado por intenso fraturamento dos minerais de minério mais antigos dos veios. Provavelmente esta movimentação foi mụito pequena e não provocou deslocamentos relati vos dos veios.

Os estudos efetuados por nós permitem concluir que no Distrito Cuprí fero de Camaquã, predomina falhamentos NW, com idades pré e pós mineralização. Os falhamentos pré-mineralização, com máximos já identificados estatisticamente, são nor mais e formam ângulos, que va riam entre 60 e $90^{\circ}$ com as falhas proeminentes de direçäo N $30-40 \mathrm{E}$, do sistema Irapuá. 
As falhas do Sistema Çêrro dos Vigias têm direção aproximada $\mathrm{N} 60 \mathrm{~W}$ e são tipicamente tensionais; possuem mergulhos verticais e os rejei tos são também verticais de pequena amplitude, de acordo com a defi nição de Ribeiro et al (1966, pag. 157).

Segundo Ribeiro e Carraro (1971), estas falhas devem estar correla cionadas com a "Reativação Wealdeniana" definida por Almeida (1967), removimentando fraturas antigas de direção NW não mineralizadas. De todos os falhamentos deste sistema a estrutura mais importante (Fig. no 3), é a falha que contém dique de diabásio na Mina S. Luiz. Sua direçäo média está em torno de N 65 - $75 \mathrm{~W}$ e os mergulhos obser vados, em todos os níveis da Mina S. Luiz, são irregulares, NE a SW; (Fig. no 22) O caimento do corpo é subvertical. As paredes da falha e os veios vizinhos estäo fortemente brechados; provàvelmente, desloca mentos verticais de pequena envergadura ocorreram, o que é sugerido pelo pequeno rejeito, observado no mapa superficial, entre os contatos Arenito Superior/ Conglomerado Superior. Deve-se ainda assinalar, que nos níveis 300 e 700 da Mina S. Luiz, em superfícies frescas do dique, foram observadas falhamentos com direçöes variando entre $\mathrm{N} 70 / 80 \mathrm{~W}$ e mergulhos $80 \mathrm{NE} / 78 \mathrm{sW}$, respectivamente, cortando longitudinalmente o corpo de diabásio. Estas fraturas indicam a exis tência de movimentos mais recentes, pós intrusão do dique de diabásio.

Independentemente das fraturas já referidas foram identificadas, em subsolo, falhamentos com direção NE de baixo ângulo de mergulho, ainda não citados. Estas falhas são de idade pós-mineralização, pos suem direção NE e mergulhos NW, sendo sensivelmente paralelas às direções médias dos acamamentos.

A Falha Piritas constituí representante típica desse grupo (Fig. 21). Ela corta o sistema de veios da Mina Uruguai, tendo direção N $55 \mathrm{E}$ e mergulho médio 35 \% NW. Os dados de sondagem, sugerem pequeno acavalamento do bloco norte sobre o bloco sul, tratanda-se de provável falha de empurrão (Fig. 13). 
Estes falhamentos sugerem que, após o estágio de mineralização, a componente dos esforços com direção NW / SE, já referida, foi inten sificada, de maneira a se tornar o esfôrço predominante na área, responsável por este tipo de falhamento.

Algumas dobras menores, associadas aos grandes falhamentos $\mathrm{NE}$, também ocorrem no distrito e no Membro Mangueirão. Digna de nota é a estrutura anticlinal, de mergulho NE, observada na Formação Santa Bárbara.

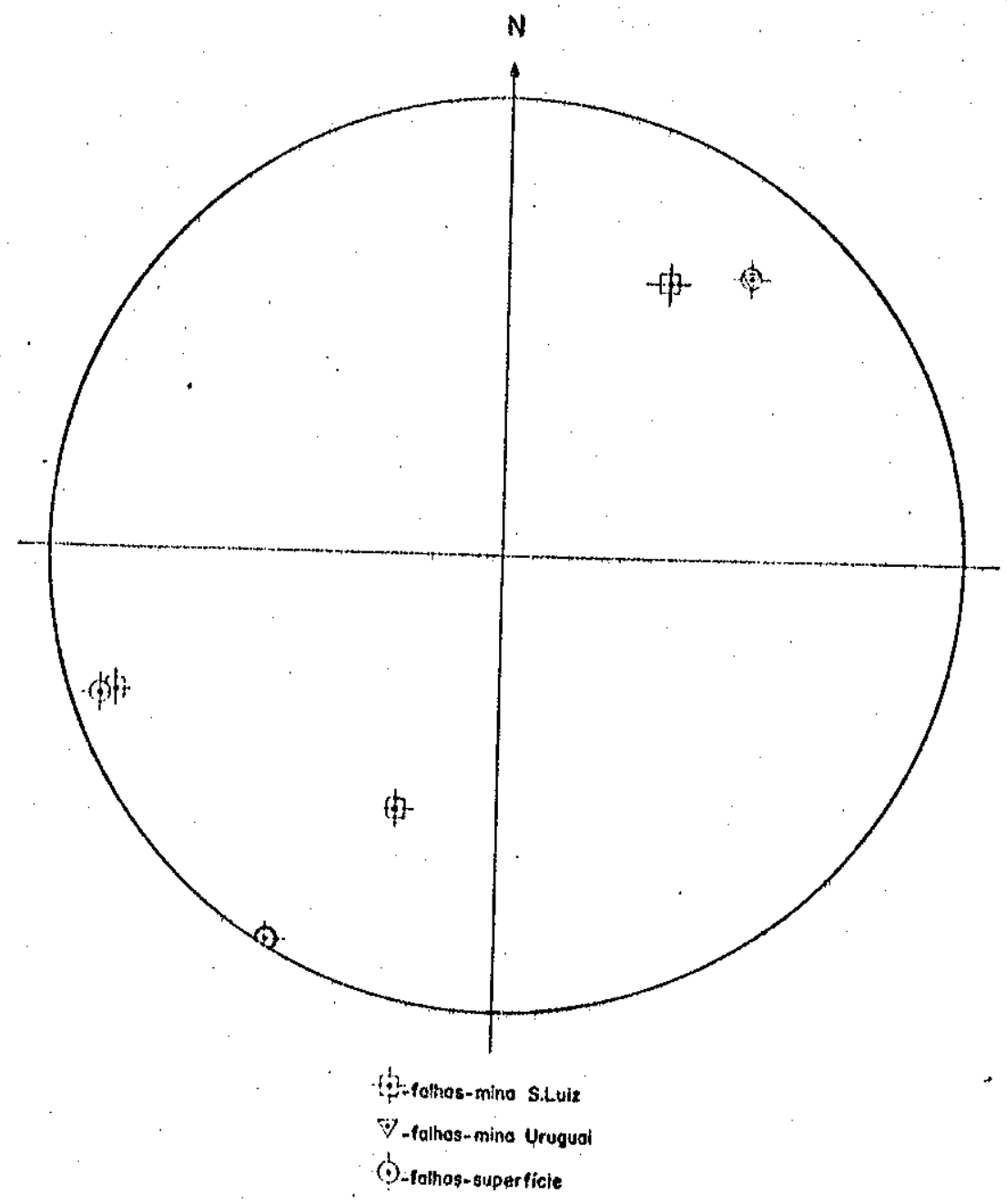

Fig. 9 Diagrama síntese de polos das normais (obtidas na rede Schmidt - Lambert, hemisfério inferior), as falhas prin cipais da Mina de Camaquá. 


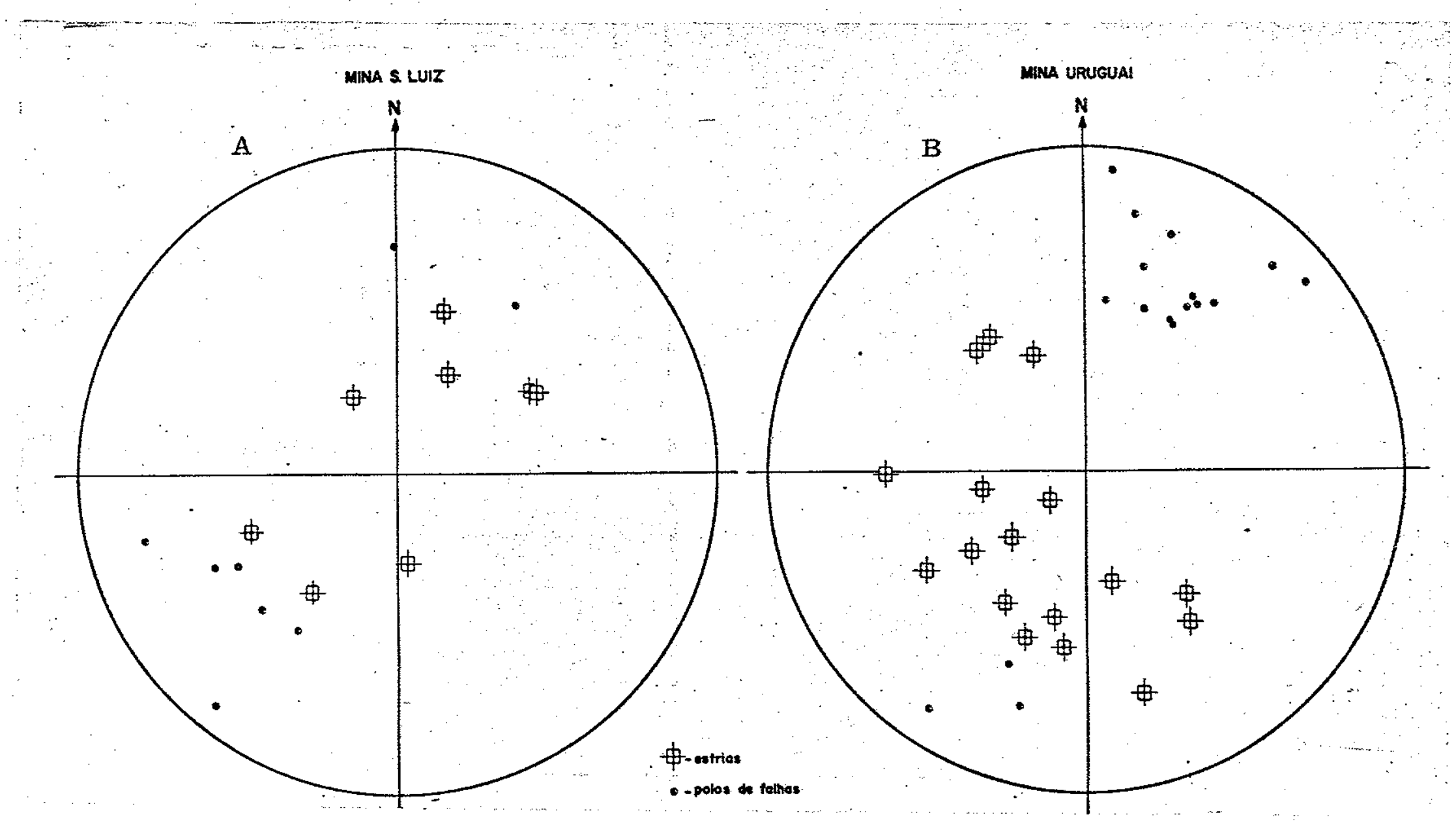

Fig. 10 Polos das normais (obtidas na rede Schmidt - Lambert, hemisfério inferior), a falhas principais das minas S. Luiz (A) e Uruguai (B), com projeçōes das estrias correspondentes. 
minas uRUGUai E SÃO LUIZ

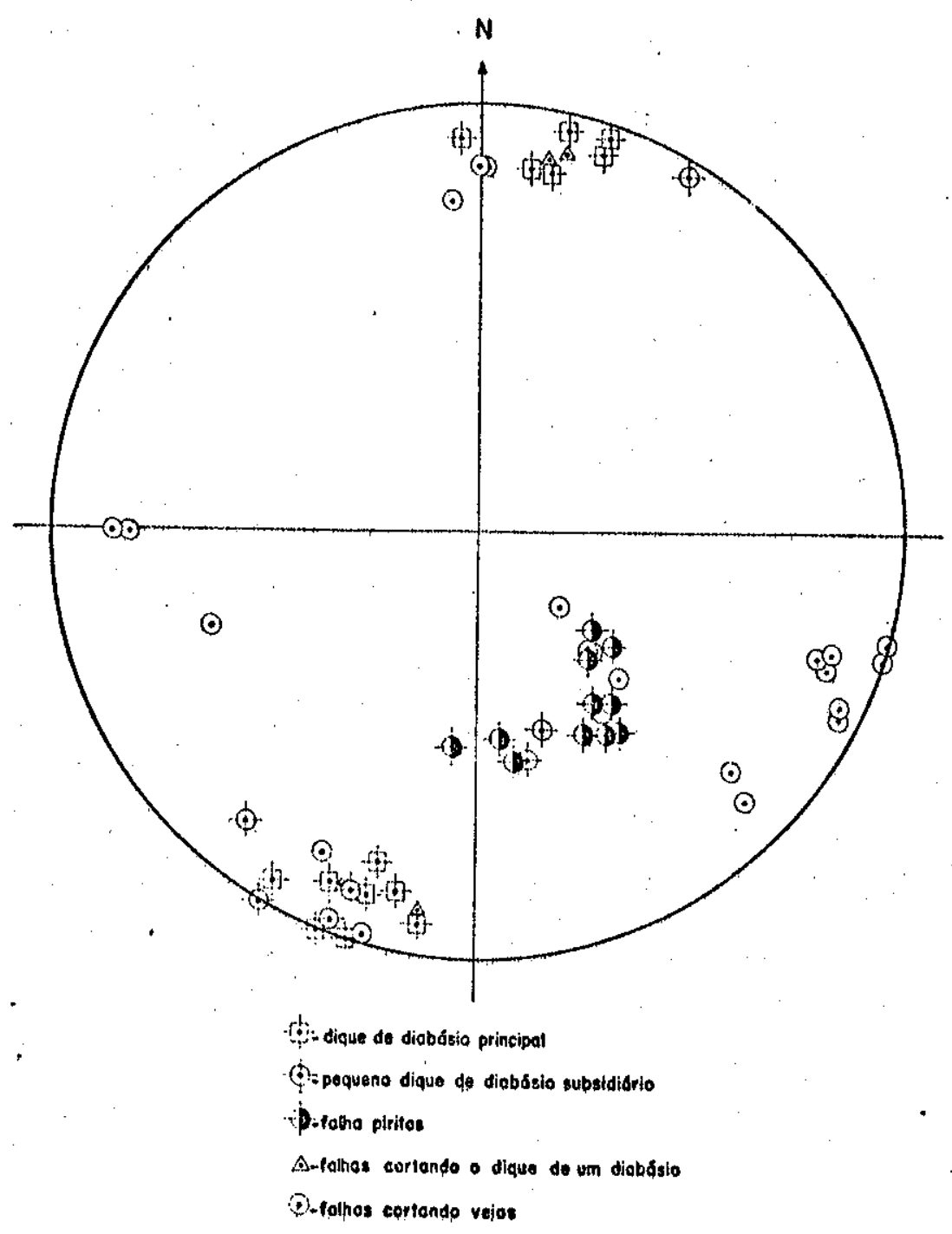

Fig. 12 Polos das normais (obtidas na.rede Schmidt-Lambert, hemisfério inferior) a fraturas pós - mineralização. 


\section{IX - VEIOS E MINERALIZAÇĀO}

Todos os filões que ocorrem no Distrito Cuprífero de Camaquã, se guem fissuras pré-mineralizaçāo jả qualificadas no capítulo anterior. Essas fraturas pertencem ao Sistema Irapuá e são principalmente constituídas por falhas normais escalonadas oblíquas ou transversais às direções das camąas, falhas menores e juntas penadás subordina das.

O diagrama síntese dos resultados estatísticos obtidos para falhas principais no distrito (Fig. 9 ), aponta a existência de duas classes de falhas maiores,

$$
\begin{aligned}
& \text { Classe 1 - } \quad\left[\begin{array}{l}
\text { N } 50 \mathrm{~W}-71 \mathrm{SW} \\
\mathrm{N} 60 \mathrm{~W}-60 \mathrm{NE} \\
\mathrm{N} 68 \mathrm{~W}-89 \mathrm{NE}
\end{array}\right. \\
& 51 \mathrm{NE} \\
& \text { Classe 2- N } 20 \mathrm{~W}-81 \mathrm{NE}
\end{aligned}
$$

que, juntamente com as falhas menores e juntas penadas subsidiárias, foram as depositárias de mineralização sulfetada local. Na Mina S. Luiz ocorrem dois conjuntos de veios oblíquos entre si. Os filões do primeiro conjunto se formaram em planos de falhas da classe 2, nas quais houve grande desenvolvimento de brechas e milonitos. O segun do conjunto é oblíquo ao primeiro e a mineralização ocorreu nas falhas, cujas atitudes correspondem às da classe 1 já definida. Neste caso, houve maior desenvolvimento de brechas e espaços abertos que, em alguns casos, facilitaram a formação de veios possantes.

A lavra já efetuada até ao nível 600 indica que o limite da zona de mi neralização econômica é subvertical, na extremidade NW e, no extre mo SE, deve acompanhar o contato Arenito Inferior - Conglomerado Inferior. No entanto, resta dúvida quanto a esse limite inferior, o que será discutido no capítulo "Contrôles de Mineralização". 
Na Zona Uruguai, na quase totalidade, os filöes ocupam os planos das falhas N $50 \mathrm{~W}-71 \mathrm{SW}$ pertencentes à classe 1, havendo, contudo, inúmeros veios importantes, formados em falhas menores e juntas penadas já descritas.

O limite da mineralização econômica é subvertical na extremidade NW e, na porção SE, acompanha a inclinação das camadas do Arenito Inferior, cujos valores de mergulho variam de 30 a $35 \% \mathrm{SW}$. No entanto, a comprovação de minério no contato Arenito Inferior - Conglomerado Inferior, leva a admitir que, em profundidade, os limites da minera lização são irregulares e não seguem, em definitivo, esse contato.

As maiores concentraçōes de minério observadas no distrito, estão localizadas nas minas S. Luiz e Uruguai onde ocorrem os filões com maiores possanças. A mineralização hipógena é representada pelos minerais, pirita, calcopirita e hematita: bornita e calcosita também hipógenas podem também estar presentes. Os minerais de ganga mais importantes que acompanham esses sulfetos são quartzo, barita e calcita.

A mineralização que ocorre na Zona Intermediária, seguiu falhas me nores subsidiárias, pertencentes aos conjuntos $\mathrm{EW}-90$ e N $70 \mathrm{E}-$ $80 \mathrm{NW} / 80 \mathrm{SE}$ já caracterizadas à superfície. Os limites dessa mine ralização não foram definidos em profundidade, devido à densidade do fraturamento e desconhecimento do comportamento da mineralização em profundidade,

Os veios da Zona Potreiros ocupam planos de falhas pertencentes à classe 1 já definida. Os filōes da Zona Oscarino praticamente dão con tinuidade à Zona Potreiros, e portanto possuem as mesmas caracterís ticas. A mineralização nestas zonas é típica, sendo predominantemente constituída por minerais de ganga, especificamente, quartzo, barita e calcita. A mineralização cuprífera é restrita. Os teores médios em cobre são da ordem de $0,8 \%$. As zonas Feliciano e Cêrro das Tunas possuem filóes encaixados em falhas pertencentes à classe 1 , sendo praticamente continuação dos veios da Zona Piritas. 
A exemplo dos setores Oscarino e Potreiros a mineralização cuprífe ra é escassa, e os veios são na maior parte constituídos por quartzo, barita, calcita. Sulfetos primários e supérgenos também ocorrem e os teores médios em cobre são tambẻm da ordem de $0,8 \%$.

O Filäo Esperança se formou em falha pertencente à classe 2 e no Conglomerado Superior. Os filões Sāo Júlio e Barnabẻ ocupam falhas da classe 1 que se desenvolveram no Conglomerado Inferior. A mine ralização nestes veios é predominantemente constituída por sulfetos primários e supérgenos. Os minerais de ganga mais frequentes são, quartzo e barita.

Os padröes estruturais dos veios, observados nas minas S. Luiz e Uruguai estão representados nos mapas de: superfície (Fig. 3), nível 500 da Mina S. Luiz (Fig. 14) e nível 400 da Mina Uruguai (Fig. 15). 


\section{1 Generalidades}

A mineralização cuprífera no Distrito de Camaquã foi guiada, em pro fundidade, por condutos representados pelos grandes falhamentos de direção NE e principalmente pelas falhas tracionais normais de direção NW, todas já qualificadas pela análise estatística. As falhas de direção NW, representadas pelas classes:

$$
\begin{aligned}
& 1\left[\begin{array}{rr}
\mathrm{N} 50 \mathrm{~W} & -71 \mathrm{SW} \\
\mathrm{N} 60 \mathrm{~W} & -60 \mathrm{NE} \\
\mathrm{N} 68 \mathrm{~W}- & 89 \mathrm{NE} \\
& 51 \mathrm{NE}
\end{array}\right. \\
& 2 \quad \mathrm{~N} 20 \mathrm{~W}-81 \mathrm{NE}
\end{aligned}
$$

na zona da Mina, foram de fato os portadores de minério por excelência, e nelas está localizada a maior parte dos filóes. Em segundo lugar, e como decorrência dos movimentos nos planos das falhas maiores, devem ser consideradas as falhas menores, juntas penadas e brechas que, por si, constituiriam condutos de segunda ordem; estas não deixam de ser importantes, também, como estruturas favoráveis à deposição de minério.

Além do controle estrutural, a deposição de minério esteve também sujeita a controles litológicos e estratigráficos. Na área são represen tados por; irregularidades ao longo da direção dos filões, mudanças litológicas, variaçōes de mergulho, mudanças de características físi cas das paredes e presença de material brechado ou milonitizado, fatores que, no entanto, condicionam a persistência dos veios, e seu conteúdo de minério em três dimensões. 


\section{2 Controles Estruturais}

\section{X.2.1 Interseccōes de Fraturas}

Enriquecimento em minério é encontrado nas intersecções de veios, fato comum, principal na Mina S. Luiz, quando há encontro dos con juntos de falhas com as direções, N $60 \sim 68 \mathrm{~W}$ e $\mathrm{N} 20 \mathrm{~W}$.

Observou- se também concentração de minério quando há ramificações de vários veios, a partir de um tronco comum mineralizado. A Fig. 16 ilustra estes tipos de controle.

\section{X. $2.2 \quad$ Estruturas Penadas}

Estas fraturas são oblíquas ou subverticais às falhas principais; em sua maior parte apresentam baixo ângulo de mergulho e pequena pex sistência lateral. A sua extensão é limitada e a mineralização decres ce com o afastamento da falha ou veio principal. Normalmente, estão associadas a zonas de falhas milonitizadas, mineralizadas ou não, mas indicando maior movimentação durante a deposiçāo do conteúdo das so luçöes. Especialmente na Mina Uruguai, este tipo de fratura minerali zada ocorre em abundância, constituindo o melhor minério maciço local. Devido ao baixo ângulo de mergulho, entretanto, muitas vezes a sua lavra é negligenciada por não se enquadrarem ao método de desmon te, aplicado aos veios principais.

A Figura 17 ilustra as relaçöes entre as fraturas penadas e as falhas às quais se associam.

\section{X.2.3 Falhas Menores}

Nos níveis 400 e 500 da Mina S. Luiz, um conjunto de falhas menores está particularmente bem desenvolvido. São paralelas à falha principal $\mathrm{N} 60 \mathrm{~W}$; apresentam mergulhos altos e as espessuras podem atingir 30 centímetros. Estas estruturas estão localizadas na capa da sua congênere principal e provavelmente resultaram do afundamento do bloco da capa, conjugado com uma mudança marcante de atitude da falha (Fig. 18 ). 


\section{X. $2.4 \quad$ Caracteres Físicos das Rochas Encaixantes}

Localização de minério devido a mudanças das características físicas das rochas encaixantes foram observadas na Mina S. Luiz. Os filöes de minério desaparecem abruptamente quando passam de conglomera do a arenito, restando somente os planos das falhas completamente estéreis (Fig. 18 ).

\section{2.5 Irregularidades dos Planos das Falhas}

Veios apresentando espessuras e conteúdo de minério, variáveis ao longo da direção, são comuns. Este comportamento é comumente observado em vários distritos mineiros e foi descrito por New house, 1942.

Certas partes da superfície original da fratura sofrem atrito entre si, enquanto em outras porções há um afastamento das paredes resultando em preenchimento local. Como decorrência deste fenômeno na Mina S. Luiz e especialmente na Mina Uruguai, em muitos casos, não há continuidade do veio ao longo do plano de falha. Em longos trechos desses planos pode haver grande desenvolvimento de milonito, com fraca disseminação de sulfetos, alternados com zon as caracterizadas por veios maciços depositados em espaços abertos ou com predominân cia de brechas.

Na Mina S. Luiz, na maior parte das vezes, as paredes estão silicifi cadas e brechadas, notando-se pouco desenvolvimento de milonitos. Em contrapartida, na Mina Uruguai, os fenômenos de caolinização e sericitização são mais intensos e predominantes, fato que, conjugado com os movimentos contínuos das falhas, ocasionavam formação intensa de milonito, com impermeabilização subsequente de grandes trechos das falhas o que confere à mineralização um carâter extremamente irregular. 
Aumento na espessura dos veios também foi observado nas zonas onde - mergulho do plano de falha é rnais pronunciado.

Estes relacionamentos estão ilustrados na Figura 19.

\section{2.6 Movimento Intra-minério}

Este tipo de controle é explicado pela movimentação operada em pla nos de fraturas que se desenvolveram perpendicular ou obliquamente à direçāo dos veios, durante a mineralização (Fig. 19).

\section{X.2.7 Zonas de Brechas}

A movimentação nos planos das falhas principais foi intensa, de ma neira que, normalmente, há desenvolvimento de brechas, nas paredes, nos planos e nos espaços compreendidos entre as falhas.

Estas brechas são particularmente bem desenvolvidas em conglomera do. A disseminação de sulfetos é grande e os fragmentos das rochas encaixantes, ou mesmo os próprios sulfetos, podem estar cimentados por hematita e minerais de ganga primários, especialmente os das últimas fases de mineralização. Muitas vezes há acompanhamento por bolsões e vênulas múltiplas, mineralizadas a sulfetos ou quartzo.

Na Mina Uruguai, particularmente nos níveis 300 e 400 da Zona Piritas, o fraturamento é tão intenso que, ao lado de brechas cimentadas a he matita ou sulfetos, frequentemente se desenvolveram estruturas que podem ser caracterizadas como "stockworks".

As zonas brechadas nos espaços compreendidos entre as falhas podem possuir mineralização disseminada. Na Mina S. Luiz, no entroncamento dos filóes 6,9 e 12 , a norte do diabásio, formou-se uma zona de intenso brechamento, observável em todos os níveis dessa mina e que constitue uma das regiões mais ricas em minério. 
As Figuras 16,18 e 19 mostram este comportamento em alguns locais importantes.

\section{3 Controles Estratigráfico e Litológico}

Conforme já foi citado, no Distrito de Camaquã, a mineralização se restringe às rochas dos Membros Mangueirão e Vargas. Os mapea mentos geológicos de superfície e subsuperfície têm demonstrado que a composição da rocha encaixante exerceu influência primordial na deposição e localização de minério. De um modo geral, as grandes concentrações econômicamente utilizáveis, estão localizadas no Con glomerado Vargas. As observações de superfície mostram, também, que elevado número de veios das Zonas Oscarino, Potreiros, Cêrro das Tunas e Feliciano, localizados nos sedimentos do Membro Man gueirão e Arenito Inferior (Fig. 3 ), possuem possanças comparáveis aos das Minas S. Luiz e Uruguai. Nestes veios a mineralização é pre dominantemente constituida por minerais de ganga, nomeadamente quartzo e barita, émbora também ocorram sulfetos em quantidades reduzidas, de modo que o teor médio ponderado nesses minérios che ga a atingir 0,6 a $0,8 \%$.

A alteração de paredes nos arenitos é reduzida, quando comparada àquela observada em conglomerados, resumindo-se a silicificação, cloritização e sericitização, com caráter poucó intenso.

Nos conglomerados, a deposição do minério foi con dicionada por mu danças químicas devidas a reações com as soluçōes mineralizantes em conjunção com as características fisico-mecânicas da rocha. A deposição se deu em fissuras, mas também segundo disseminação em várias zonas do depósito, tais como, a extremidade NW da Mina Uru guai, a zona sul do diabásio e Lapa do depósito. Sua formação está sempre relacionada a fraturamento, porosidade e permeabilidade da rocha. 
Deve-se assinalar, no entanto, que as sondagens profundas efetuadas na Mina Uruguai, demonstraram a existência de corpo de minério localizado no contato entre o Conglomerado Vargas e o Arenito Infe rior (Fig. 13). As descrições macroscópicas demonstram também, que a maior parte do minério é de preenchimento, em fraturas mili métricas e centimétricas, dispostas em rede, e não como mineraliza ção de veio, como seria de esperar. Este fato, contradiz o caráter pouco favorável de arenito à deposição de sulfetos. Ao que parece, entretanto, este minério se formou no contato entre rochas de dife rentes competências, fisicamente dissimilares, e ao longo da zona de falhamentos, onde as falhas principais devem sofrer deflexões, que ocasionam fraturamento e brechamento em grande escala, ao longo do contato, conforme Newhouse (1942, pág. 11). A localização deste corpo deve ser encarada como um exemplo de minério que pode ocorrer em todo o distrito, nas regiōes onde as falhas principais, atravessam os contatos Conglomerado Superior e o Arenito Inferior. 


\section{MINA URUGUAI}

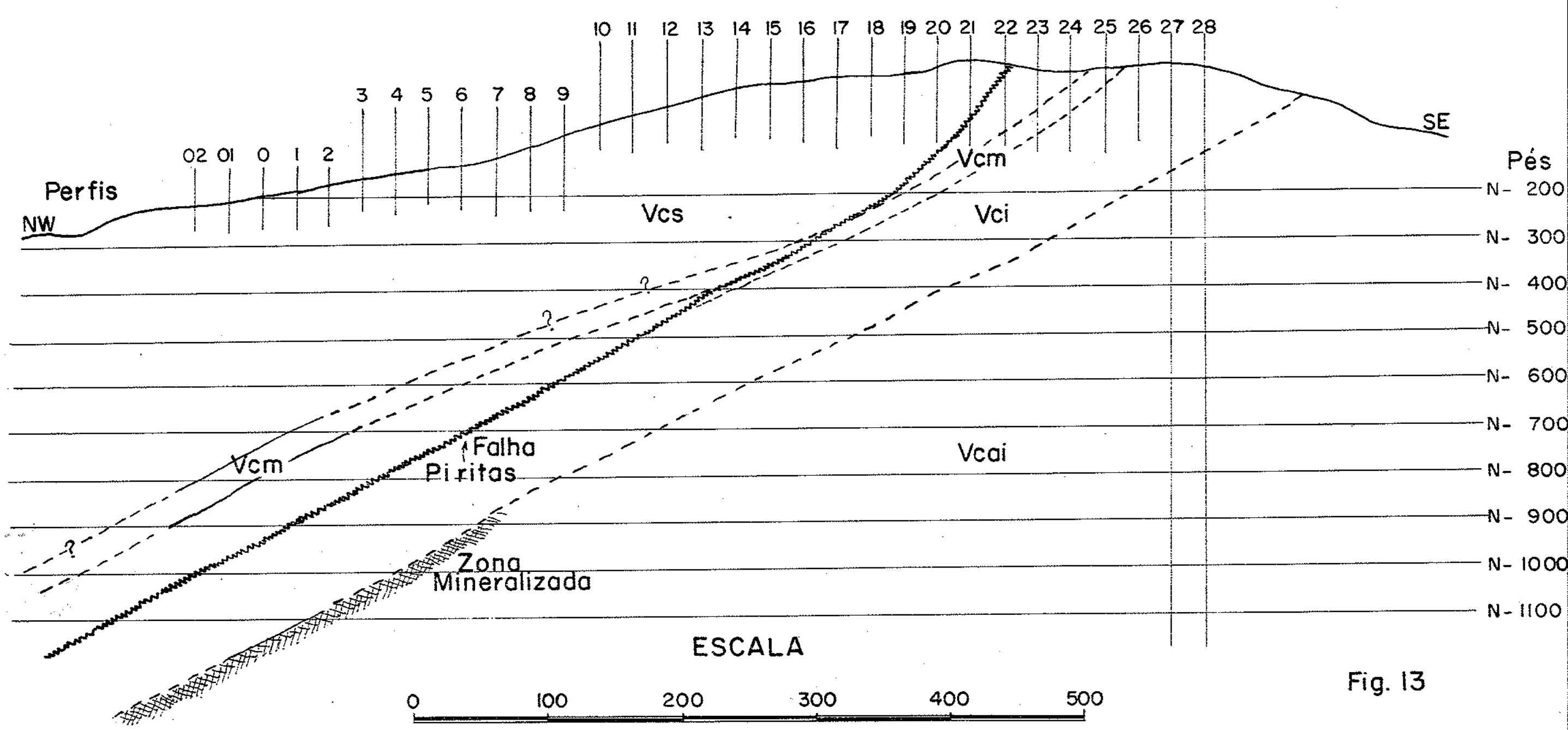

Perfil longitudinal segundo a linha base.

O corpo de minério está localizado na zona de contato Arenito Inferior-Conglomerado Inferior. 
XI - CORPOS DE MINÉRIO

\section{XI.1 Generalidades}

As antigas descrições feitas por Teixeira (1941), Costa Filho (1944) e Leinz e Almeida (1941), referem-se aos veios na Jazida de Camaquã, considerando a existência dos filöes S. Luiz, Barnabé, S. Júlio, ES perança, Filão Potreiros, Filão Viktor Leinz, Filão Feliciano e Filão Salso, nos diversos setores da Mina. Entretanto deve-se assina lar que o volume de trabalhos mineiros e de pesquisa, já efetuados nos últimos 30 anos, demonstraram a existência de um sistema de veios mais numeroso e complexo do que aquele descrito por esses autores. Em função dos trabalhos mineiros e de mapeamento de deta the feitos nas galerias principais e subníveis, especialmente nas minas Uruguai e S. Luiz, tentou-se neste trabalho descrever em pormenor es o comportamento estrutural dos principais filoes, de mo do a fornecer subsídios ao melhor entendimento dos mesmos, em pro fundidade.

Considerando o grande número de filóes que ocorrem na área, sòmente serão descritos aqueles que se revelam de maiorimportância. O prin cipal esforço nesse sentido foi o de correlacionar ou identificar esses veios com os sistemas de fraturas, caracterizados pela análise tectô nica, desvinculando-os do tratamento mineiro a que vinham sendo submetidos, pelo qual algumas vezes eram incluıdos sob a mesma designação vários filões vinculados a fraturas de conjuntos diferentes. Os veios assim individualizados serão numerados e, sempre que possível, acompanhados da designação antiga. Apresenta-se também os mapas de níveis, perfís longitudinais com os limites dos corpos de mi nério e também, alguns perfís transversais, mostrando as relações entre os veios (Figs. 20, 21, 22 e 23).

Deve-se frisar que a lavra desses corpos de minério sempre foi feita no Conglomerado Superior, na Mina S. Luiz; e, no Conglomerado Supe rior, Arenito Médio e Conglomerado Inferior, na Mina Uruguai. 
Sabe-se também, que o mesmo sistema de falhas têm persistência em profundidade além do Arenito Inferior, com os planos das falhas seleti vamente mineralizados.

Os limites dos corpos de minério, ora representados, restringem-se simplesmente às zonas já lavradas. A simples análise dos perfís longi tudinais dos filões, conjugada com os mapas de níveis, deixam claro que muito trabalho de pesquisa é necessário para que a real configura ção dos corpos de minério seja estabelecida em profundidade.

\section{XI.2 Mina S. Luiz}

A Mina S. Luiz foi tradicionalmente dividida em dois setores, Norte e Sul, em relação ao dique de diabásio. Os filöes existentes em cada um dos lados sempre foram considerados em conjunto, mas neste tra balho serão analisados individualmente para posterior correlação. Os principais corpos, ẹm número de 13 , podem ser observados no mapa superficial (Figno 3), mapas de distrito, perfís longitudinais e plantas de níveis. ( Fig. 20).

Entre esses, os principais serão descritos sucintamente, assinalando-se também a existência de vários outros filões e zonas com mineralização disseminada que não serão considerados aqui.

O mapeamento e a reconstituição da geometria destes corpos nos ní veis superiores, especialmente nos níveis 100, 200 e 300 , é tarefa árdua devido a obstruções nos trabalhos antigos ou mesmó lavra contí nua de certos corpos do nírel 300 ao nível 100 que impedem observações mais detalhadas e correlaçäo eficiente entre os filöes.

\section{XI.2.1 Zona Sul do Diabásio}

XI.2.1.1. Filāo 1 (Filão S. Luiz ou Principal) 
Nas descrições antigas de Costa Filho (1944) e Leinz e Almeida (1941) - Filão S. Luiz abrangia várias ramificações acima do nível 300 incluin do, a sul do diabásio, os ramos conhecidos como veios Rico Oeste e Leste e, a norte do diabásio, Zonas Oeste e Leste. Neste trabalho, o Filão 1 foi individualizado conforme indicado nos mapas superficial e de níveis (Figs. 20 e 22),notando-se tạmbém as ramificações, antigos veios Oeste e Leste, aqui denominados filóes 2 e 14.

O Filão 1, a sul do diabásio, estende-se por 430 metros até ao Poço 8, continuando pelo Conglomerado Inferior por mais 100 metros, represen tado por uma fratura pobremente mineralizada e esvanecida.

A superfície, a direção média é da ordem de $\mathrm{N} 25 \mathrm{~W}$, não havendo grandes variações em profundidade. Os mergulhos são baixos varian do entre os limites 509 a 75 \% NE e em profundidade variam de $75 \circ$ a $85{ }^{\circ} \mathrm{NE}$.

O mapeamento geológico demonstra que a espessura deste veio atinge 1,20 a 1,30 metros no Conglomerado Superior, reduzindo-se a poucos centímetros no Conglomerado Inferior, conforme observações à super fície.

Em todos os níveis, a exploração se restringiu ao Conglomerado Supe rior. Nesta parte, a sul do diabásio, os limites da mineralização econô mica foram considerados como sendo o próprio contato com o Arenito Médio, e o caimento é da ordem de $30 \%$, conforme com o mergulho das camadas de arenito. Trabalhos de sondagem e mapeamento demonstra ram a existência de minério no Conglomerado Inferior, seguramente ao longo dos mesmos planos de falha em profundidade.

Esta zona, embora parcialmente pesquisada, aguarda trabalhos de desenvolvimento adicionais.

Na extremidade SE, a partir do nível 100, Pôço 3 , por dificuldades de mapeamento geológico e falta de caracterização precisa, de acôrdo 
com o que é sugerido à superfície, admitiu-se que os filoes 1 e 2 coexistem num único tronco ou estão emparelhados a distância míni ma, em todos os níveis, $100,200,300,400$ e 500 .

Este filão foi lavrado até ao nível 500, restando porções de minério remanescentes de lavras antigas, minério deixado nas vizinhanças de poços de extração e ainda em zonas abertas do nível 600. A situação atual é:

Nível 100 os trabalhos continuam

Nível 200 a veio foi lavrado parcialmente, restando ainda alguns blocos situados a SE do Poço 3.

Nível 300 os blocos existentes nas vizinhanças dos poços 10 e 12 que ainda estäo em operação.

Nível 400 a lavra foi até ao Poço 10, restando ainda porções de minério a SE e junto aos poços 10 e 12 .

Nível 500 resta minério junto aos poços de extração já referidos.

O perfil longitudinal deste filão está configurado na Fig. 22, demons trando persistência em profundidade, no Conglomerado Inferior e Arenito Inferior.

\section{XI.2.1.2 Filão 2 (Filão Lapa)}

As descrições feitas por Costa Filho (1941, planta 18, perfil do Furo 4), referem-se às ramificaçōes do Veio $\mathrm{S}$. Luiz conhecidas como veios Rico Oeste e Leste, que foram outrora parcialmente lavrados do nível 100 até à superfície (Fig. 22). Os trabalhos de mapeamento no nível 100 indicaram a existência dos dois filöes, que se unem para constituir o antigo Filão Lapa, e que aqui será denominado Filão 2 , incluindo o antigo Veio Leste. 
A superfície tem extensão de 85 metros até encontrar o Filão 1 do qual é uma ramificaçāo. A direção é irregular, variando de N 20 a

$26 \mathrm{~W}$, sendo a direção média $\mathrm{N} 22 \mathrm{~W}$. Os mergulhos variam entre 50 e $75 \mathrm{NE}$ tornando-se mais pronunciados no nível 500, quando variam de 63 a $77^{\circ}$. As características de possança e teor são variá veis ao longo da direção e também na vertical. A espessura varia, principalmente, quando há ondulações de paredes, mudança de direção ou entroncamento com fraturas oblíquas. No nível 100 a possança pode atingir até 2,50 metros e nos níveis 500 e 600, entretanto, as espessuras se reduzem podendo atingir 10 centímetros.

A análise dos mapas de níveis permitem as seguintes observações:

Nível 100 o entroncamento dos filöes 1 e 2 migra para SE, notando-se que a individualização deste corpo começa a se efetuar neste nível.

Nível 300 . o comprimento máximo é atingido, sendo da or dem de 140 metros. Entre os perfís 8 a 15 a fratura continua, embora fracamente mineralizada.

Nível 400 a junção com o Filão 1 persiste até à altura do Poço 10. Neste nível foi pesquisado por galeria de nível.

Nível 500 a distância em relação ao Filão 1 é pronunciada, devido a diferenças de mergulhos dos dois corpos. O comprimento é mínimo, de cêrca de 85 metros. Os mergulhos do veio variam de 63 a 77 . Não foi trabalhado em bom trecho, provàvelmente por não revelar teor econômico. 


\section{XI.2.1.3 Filão 3 (Filão Capa)}

De todos os filões a Sul do diabásio o de número 3 é o menos conhe cido pelo fato de não ter sido desenvolvido sistematicamente, por galerias de distrito. A superfície, este veio está parcialmente expos to, inferindomse: sua reunião com o Filão 1, à altura do Poço 7 , para formarem um tronco comum.

O comprimento deste filão a Sul do diabásio e à superfície é da ordem de 340 metros, até às proximidades do Poço 7; sua direção média é $\mathrm{N} 16 \mathrm{~W}$, o mergulho vertical a subvertical. O perfil transversal $\mathrm{P}-16$ (Fig. 22), entretanto, demonstra claramente as inflexões deste veio, e a maneira como, por diferenças de atitude, tende a se unir em pro fundidade ao Filäo 1.

Nos locais onde é conhecido possui espessura variável. Nos níveis 100 e 400, a possança varia de 0,15 a 1 metro, podendo atingir 2 metros se as zonas. brechadas associadas forem levadas em conside ração. A exemplo dos outros filöes, a exploração se restringiu ao Conglomerado Superior, sendo os contrôles de mineralização os mesmos descritos para o Filão 1. Admite-se que, abaixo do nível 500, este filão tem a tendência de se unir, progressivamente, ao Filäo 1 de SE para NW.

Nível 100 foi parcialmente mapeado ao longo da Cabeceira 120. Neste nível a carência de mapeamento por galeria de distrito, entre as proximidades do Poço 1 até ao Poço 7, redunda em conhecimento imperfeito do comportamento dos filões 1 e 3 . E de se esperar que os dois veios caminhem empa relhados no sentido SE, unindo-se em um tronco comum à altura do Poço 3. No desenho dos corpos de minério, admitiu-se que os dois veios possam coexistir, tendo sido lavrados em comum nos blo cos 101 e 102 (Fig. 22), pelo menos até ao Poço 7. 
Costa Filho (1944, planta do Filão S. Luiz) apre senta um perfil do Poço 10, mostrando o que poderia ser interpretado como os dois filões emparelhados.

Nível 200 não foi explorado, na quase totalidade. Nos últi mos 3 anos foi pesquisado pela equipe da C. B.C., estando em fase de desmonte. O comportamento na extremidade SE é imperfeitamente conhecido, por falta de trabalhos de desenvolvimento.

Nível 300 Não se efetuou desenvolvimento em galeria de ní vel, mas por subnível, onde, em conjunto com o Filäo 1 já foi parcialmente lavrado. Resta ainda boa parte de minério nas zonas vizinhas aos poços de extração 10 e 12 .

Nível 400. Foi desenvolvido separadamente, mas na extre midade SE não há dados de teores e mapeamento geológico sistemático, que possam elucidar seu comportamento em relação ao Veio 1 .

Nível 500 Resta dúvida quanto ao posicionamento deste veio, mas, ao que parece, ele não foi desenvolvido no nível principal. Nos blocos 501 e 512 (Fig. 22). os teores obtidos em travessas de subnível, indi cam a existência de zona mineralizada persisten te, que muito bem pode corresponder ao Filão 3 .

O limite SE continua sendo de conhecimento imperfeito, restando a possibilidade de união com o Filão 1, explicável por diferenças de ati tudes. 


\section{2.2. Zona Norte}

\section{2.2.1 Filäo 4 (Filão Principal)}

O filão, aqui designado de número 4 (Fig. 20), abrange parte do anti go Filão Principal. Entre os níveis 100 e 300, é imperfeitamente co nhecido, pelo fato de não existirem galerias de nível, que permitissem sua observação. Os mapeamentos efetuados indicam que a partir do nível 100, começa a se desenvolver um veio oblíquo, ligando o Filão 4 ao Filão 6 , que nos trabalhos antigos foi englobado no antigo Filão Principal.

A caracterização e comportamento estrutural destes filões, vinculados a conjuntos de fraturas diferentes, forçosamente conduz à individuali zação do Filão 4 (conforme Fig. 20), considerado mais correto. A superfície, seu comprimento é da ordem de 60 metros, com direção $\mathrm{N} 52 \mathrm{~W}$, não havendo medidas de mergulho. A direção média, em pro fundidade,é $\mathrm{N} 44 \mathrm{~W}$. com os mergulhos variáveis de 70 a 85 o NE, às vezes subverticais ou invertidos, junto ao diabásio. A espessura oscila entre os limites de 0,1 a 1,5 metros, às vezes 2 metros. A exemplo dos cemais filões sua exploração se restringiu também ao Conglomerado Superior. Os trabalhos mineiros efetuados até ao nível 600 mostram que o limite de mineralização tem um caimento da ordem de 30 , entre os níveis 300 e superfície, sendo subvertical até ao nível 600. Em profundidade é de se esperar que esta zona de falhas invada o Conglomerado Inferior e Arenito Inferior, com mineralização persistente.

Entre os níveis 300 e 600, atinge comprimento de 220 metros. Até ao nível 600 este filão foi quase totalmente lavrado, restando apenas porçōes de minério de baixo teor entre os níveis 200 e superfície, além dos pilares entre os blocos já desmontados. 


\section{2.2.2 Filão 5 (Filão Lapa)}

Os trabalhos executados pela Comissão Mista, indicaram a presença deste filão à superfície, embora sem dados estruturais. O seu conhe cimento é imperfeito entre a superfície e o nível 300 , bem como nos níveis 300 e 400, por falta de mapeamento geológico, dificultado por obstruções de antigas zonas de lavra.

A superfície, o comprimento é da ordem de 80 metros, sendo truncado a NW pelo dique de diabásio, mapeado recentemente. O dique de diabá sio é oblíquo à sua direção, de modo que o traço do plano do filão com - plano do dique é uma linha oblíqua que, devido à inversão do mergu tho do veio, recua para NW, diminuindo as suas possibilidades econô micas. Embora ainda não tenha sido pesquisado no nível 600 , as evidências indicam que o veio deve estar truncado a meio painel, entre os níveis 500 e 600 , pelo dique de diabásio.

Os trabalhos de subsolo permitiram observar o seguinte:

Nível 100 do nível 100 até à superfície, é truncado pelo dique de diabásio;

Nível 300 entre os níveis 300 e 600 atinge o comprimento de 220 metros;

Nível 400 neste nível o comportamento deste filão é duvidoso na extremidade da cabeceira 401, (Fig. 20), em bora se presuma que o seu comprimento máximo, cerca de 150 metros, seja atingido neste nível;

Nível 500 a sua extensão é de apenas $45 / 50$ metros, sendo pràticamente formado por dois filóes paralelos, fracamente mineralizados e com espessuras variando de 5 a 10 centímetros. A direção média é $\mathbb{N} 40 \mathrm{~W}$, com mergulho da ordem de 60/659 NE. Entre os 
níveis 400 e 500, a atitude deste filäo sofre um desvio con inversão de mergulhos que no nível 500 apresenta valores entre 50 e 62 ? $\mathrm{NW}$.

\section{2.2.3 Filão 6 (Filão Capa)}

O corpo 6 é o filão de maior desenvolvimento à superfície, na zona norte do diabásio, sendo extremamente ramificado na extremidade NW. A altura do perfíl 22, seu tronco se bifurca em dois ramos prin cipais, que por sua vez se multiplicam em vários outros. Este conjun to invade o Arenito Superior e a extensão total chega a atingir 250 a 300 metros. Entre os níveis 100 e 300 o seu comportamento é imper feitamente conhecido, por não ter sido lavrado acima do nível 200, provavelmente por apresentar teores muito baixos em cobre. Presu me-se que abaixo do nível 100, seja truncado pelo desenvolvimento do filão oblíquo no 9, como se verifica ao nível 300 . Nos níveis 400 , 500 e 600 , este veio se identifica com a extremidade SE do filão 9 a ponto de formar umi único conjunto retilíneo, até ao dique de diabásio.

A superfície, no tronco inicial, a direção média é N $33 . \mathrm{W}$, com mergu lhos entre 60 e 68 . NE. A espessura do veio varia entre 10 centímetros e 1,5 metros.

No nível 100, é mal conhecido e os trabalhos de geologia evidenciaram fratura fracamente mineralizada nas proximidades da Chaminé - 8.

No nível 300, o desenvolvimento é notório, sua mineralização atinge extensão de aproximadamente 55 metros, apresentando ramificações e fraturas de tração oblíquas. A direção média é da ordem de $\mathrm{N} 20 \mathrm{~W}$ com mergulho entre 56 a $759 \mathrm{NE}$.

Nos níveis 400 e 500, o comprimento do filão atinge 250 metros; os mergulhos são variáveis sendo o valor médio $609 \mathrm{NE}$. Mergulhos de 45 a 50 . foram observados, podendo ser verticais na extremidade SE. 
A lavra deste veio foi feita em todos os níveis abertos, exceptuando aqueles situados acima do nível 300, provàvelmente por não apresen tarem teores econômicos justificáveis. O Bloco S. Pedro representa a única zona lavrada acima do nível 300. Os limites da mineralização a NW são subverticais, presumindo-se um comportamento idêntico em profundidade.

XI. 2.3 Outros Filões

Inúmeros outros filões foram assinalados na Mina S. Luiz, entretanto, como os mais importantes já foram descritos, alguns deles estão apenas esquematizados nos perfís transversais 16 e 21 ( Fig. 20). Entre eles, os veios mais importantes são os de número 9, 10, 11, $7,8,12$ e 13; apenas os três primeiros já foram lavrados parcialmen te entre os níveis 300 e 600 .

Os filões S.: Júlio, Barnabé e Eșperança, são muito bem co nhecidos desde o início da lavra da Mina. Dispensam maiores discus sōes uma vez que os seus detalhes já foram adequadamente descritos por Costa Filho (1944). Os dois primeiros foram parcialmente lavra dos e óltimo foi pesquisado pela C.B.C.

XI. $2.4 \quad$ Correlações

O mapeamento geológico efetuado nas exposiçóes superficiais do dique de diabásio e as observações das relações de contato com as rochas encaixantes, Arenito Superior e Conglomerado Superior, mostram a existência de pequeno rejeito da ordem de 15 metros. Este rejeito pode ser explicado por uth deslocamento vertical relativo dos blocos de falha (Fig. 3), em cujo plano se consolidou o dique de diabásio. A integração de movimento vertical de blocos, as variaçöes de mergu tho dos filóes e o afastamento médio de 20 metros das duas paredes da falha, forçosamente conduz a discordâncias entre os veios situados a Norte e a Sul do diabásio. 
Conforme pode ser observado nas diversas Figuras que ilustram o comportamento espacial dos corpos, há uma forte sugestão de correspondência entre os filöes 1 e 6,5 e 14, 2 e 4, em vista de seu posicionamento espacial e comportamento.

XI. 3

Mina Uruguai

A exemplo da Mina S. Luiz, a Mina Uruguai sempre foi subdividida em duas partes, Zona Piritas e Zona Uruguai, separadas pela Falha Piritas.

Os trabalhos de pesquisa mais recentes evidenciaram um numeroso conjunto de veios, associados às falhas principais e juntas subsidiárias. Os afloramentos observáveis em superfície, especialmente na capa do depósito, demonstram a existência de falhas contínuas, irregularmente mineralizadas. A partir de 1969, essas feições foram submetidas a intensa pesquisa por meio de sondagens rotativas, evidenciando reservas ponderáveis de minério. Ao contrário da Mina São Luiz, os trabalhos de geologia de subsolo são escassos, especialmente nos níveis 100 , 200 e 300 da Zona Uruguai e níveis 300 e 500 da Zona Piritas, apenas parcialmente desenvolvidos. Os trabalhos de mapeamento geológico nessas áreas ainda são dificultados ou tornados impraticáveis pelas obstruções e desmoronamentos de realces e galerias antigas, impossibi litando as tentativas de correlação correta entre os diferentes corpos de minério. Êste fato é particularmente notável nos níveis $200,300 \mathrm{e}$ 400 da porção NW da Zona Uruguai. Devido às dificuldades de correla ção, já apontadas, serão analisados apenas alguns filões tradicional mente lavrados; o elevado número de corpos, cujo comportamento tri dimensional demanda trabalhos adicionais de desenvolvimento e pesqui sa, presentemente em curso, será apenas brevemente mencionado. Os filöes principais da Zona Uruguai a serem descritos, são os de número $1,2,3$; os filões $16,17,1 \dot{8}$ e 19, que constituem ramificações em profundidade do Filão 2; os veios 10 e 11 da Zona Piritas. Os filões não descritos por falta de dados são: Filão no 20; Filão sôbre Capa; os corpos existentes na capa do depósito de números 4, 5, 6 e 7, existentes 
na Zona Piritas; números 8, 9, 11, 12 e 13; além de corpos ricos de pequena extensão, preenchendo juntas em pena, associados aos falha mentos principais. Os filões analisados, sempre que possível, serão também referidos à designação antiga. Embora o mapa geológico su perficial sugira continuidade de alguns filóes ou falhas da Zona Uru guai à Zona Piritas, será evitada qualquer correlação de filões, por insuficiência de dados geológicos de detalhe à superfície e subsolo, bem como por desconhecimento da extensão dos movimentos operados na Falha Piritas.

A exemplo da Mina S. Luiz, os planos das falhas portadoras de miné rio têm continuidade além do Arenito Inferior podendo estar minerali zadas.

Ao contrário da Mina S. Luiz, a lavra foi sempre conduzida no Conglo merado Superior, Arenito Médio e Conglomerado Inferior.

As projeçōes verticais de realces dos principais filöes, algumas secções transversais do depósito e projeções horizontais dos filões estão repre sentados nas Figuras 21 e 23. .

\section{3.1 Zona Uruguai}

XI.3.1.1 Filão 1 (Filão Lapa)

Os afloramentos esparsos à superficie sugerem que a fratura preenchida pelo filão tem conținuidade no sentido SE. A direção está situada entre os limites $\mathrm{N} 46$ a $\mathrm{N} 55 \mathrm{~W}$, com mergulho médio de $60 \% \mathrm{SW}$, enquanto sua espessura varia de 0,2 até o máximo de 1,10 metros. Sinuosidades e arqueamentos são comuns ao longo da direção do filão, originando variações locais de espessura e mergulhos.

As seguintes observaçōes em profundidade foram feitas: 
Nível 100 e 200

não houve desenvolvimento por galeria de nível nas extremidade SE até à Falha Piritas, provà velmente por inexistência de teores econômicos.

Nível 300,400 e 500

o filäo foi parcialmente mapeado, sendo o seu comportamento imperfeitamente conhecido na extremidade SE por falta de trabalhos de desen volvimento. Nestes níveis, o comprimento da zona mineralizada varia entre 150 até o máximo de 200 metros, no nível 400.

A lavra deste veio foi totalmente efetuada no nível 500 e parcialmente no nível 400. Recentemente foram feitos trabalhos de pesquisa e desen volvimento acima do nível 300 , com vistas ao seu aproveitamento. Muitos são os veios subsidiários que ocupam as fraturas de tração de baixo ângulo; estas, na maior parte das vezes, são lavradas em conjun to com o filão principal ao qual estão associados.

\section{3.1.2 Filão 2 (Filão Sôbre Lapa)}

A exemplo do Filäo 1, este veio não pôde ser mapeado em detalhe na superfície, de maneira a acompanhar sua evolução até à Falha Piritas, havendo entretanto alguns afloramentos isolados já mapeados, entre os perfis 7 e 11, onde possui direção média $\mathrm{N} 50 \mathrm{~W}$ e mergulho 60 ! $\mathrm{SW}$. As espessuras em todos os níveis são variáveis entre os limites 0,10 a 1,80 metros.

Nos níveis abaixo discriminados as características deste filão, são as seguintes:

Nível 200 nāo foi desenvolvido no trecho compreendido entre o perfil 12 e a Falha Piritas, nem na extremidade e NW, onde a direção média é N $53 \mathrm{~W}$, com mer gul.ho $60^{\circ} \mathrm{SW}$ e comprimento da ordem de $175 \mathrm{me}$ tros; 
Nível 300 foi desenvolvido em galeria de nível numa extenção de 180 metros, havendo continuidade até à Falha Piritas por falha pouco mineralizada. A direção média é $\mathrm{N} 50 \mathrm{~W}$ e mergulhos variáveis entre 50 e 60 9 SW. Entre a superfície e este nível o veio é homogêneo, sem ramificações importantes.

Nível 400 neste nível,o filão foi desenvolvido até à Falha Piritas e lavrado numa extensão de 220 metros, no bloco 418. A identificação das ramificações e a correlação com os seus correspondentes, pos sivelmente existentes no nível 400 , são impraticá veis, por razōes já verificadas atrás. A direção é N $50 \mathrm{~W}$ com mergulhos variando entre 50 a 65 . SW.

Nível 500 está individualizado em uma extensão de 50 me tros, entre os perfís 10 e 12, bifurcando-se na extremidade SE segundo falhas fracamente minera lizadas e que não são cortadas pela Falha Piritas. A direção média neste traço é N $63 \mathrm{~W}$, com mergu tho entre 85 a $909 \mathrm{SW}$. A espessura do filão varia de 0,10 até 1,10 metros. Entre os perfís 9 e 10 , existe clara ramificação do filão, produzindo quatro ramos que são correlacionáveis com falhas e filões mapeados nos níveis e subníveis entre os perfís 6 e 8 .

A correlação entre estes filōes e os seus possíveis correspondentes nos níveis 300 e 400 é quase impossível pois os dados geológicos não são su ficientes; além disso, esta área apresentava desmoronamentos contínuos. Neste nível esses ramos foram designados por filões 16, 17, 18 e 19 , sendo lavrados em bloco comum (Bloco 511 - 522). 
XI. 3.1.3 Filöes 16, 17, 18 e 19

O Filão 16 no nível 500 e em subnível, na quase totalidade, é represen tado por falha com mineralização esparsa, que persiste até encontrar-se com o Filão 1, formando um tronco comum. Seu comprimento é da or dem de 55 metros e a direção média é N $40 \mathrm{~W}$, com mergulhos entre 70 e 90 SW. A zona falhada possue espessura de até 1,5 metros, com mineralização disseminada e bolsões esparsos.

O Filão 17 foi parcialmente mapeado em subnível, numa extensão de 10 metros. A direção é N $65 \mathrm{~W}$ e os mergulhos variam entre 48 a 60 \% SW, com espessura de 20 centímetros.

O Filão 18 estende-se desde o entroncamento do perfil 10 até o perfil 16, podendo ter continuidade até além do perfil 5, em vista dos dados de sondagem efetuados neste nível. A direção média é $\mathrm{N} 70 \mathrm{~W}$, com inflexão para SW na extremidade. Os mergulhos são variáveis, atin gindo 80 SW no entroncamento com o Filão 2 e 40 SW na extremida de SW. A espessura varia de 0,1 a 1,10 metros.

O Filão 19 é também representado por falha com trechos de minerali zação disseminada, alternada com zonas onde predomina minério ma ciço. A mineralização observada estende-se por 65 metros, podendo continuar até além do perfil 5 , conforme resultados de sondagem já efetuada no nível 500. Sua direção média é N. $75 \mathrm{~W}$ com mergulhos variando de 50 a $75 \circ$ SW e espessura da zona falhada em torno de 1,2 metros.

\section{XI.3.1.4 Filão 3 (Filão Capa)}

Este filão foi mais intensamente pesquisado à superfície por trincheiras em toda a sua extensão, até às proximidades da Falha Piritas; provàvel mente tem no Filão 13 seu correspondente além da Falha Piritas. Em superfície, o comprimento mineralizado é de cerca de 380 metros, em bora os teores econômicos se resumam a áreas restritas. A direção 
média na maior parte do filão é $\mathrm{N} 55 \mathrm{~W}$, com irregularidades na extre midade SE e contornos arqueados; os mergulhos variam de 65 a a 85 \% SW.

Nível 200 foi parcialmente desenvolvido numa extensão de 205 metros, entre os perfís 5 e 13; sua continuida de até à Falha Piritas, provàvelmente existe, por falha fracamente mineralizada;

Nível 300 neste nível, o filäo ocupa uma extensão mineraliza da de 175 metros. Entre o perfil 13 e a Falha Pi ritas, não foi desenvolvido provàvelmente por não apresentar teores econômicos. A direção é $\mathrm{N} 57 \mathrm{~W}$ e o mer gulho médio, 70 ㅇ․ SW.

Nível 400 possue grande desenvolvimento, predominando trechos representados por falhas com muita bre - cha e mineralização esparsa. O comprimento mi neralizado é de 175 metros até ao perfil 5, com continuidade provável até o perfil 3. A direção média é sensivelmente igual à dos níveis superio res e os mergulhos são baixos na extremidade NW, variando de 40 a 50 S SW.

A possança, em trechos isolados entre os perfís 9 e 11 , varia entre 0,5 e 1,10 metros.

Nível 500 neste nível, os trabalhos de desenvolvimento estão sendo feitos, razão pela qual a caracterização do veio é precária. Entretanto, deve-se assinalar que a partir do níve1 400 a mineralização é extre mamente irregular e pobre ao longo de falhas, devido à predominância de brechas argilosas nesses planos. 


\section{3.2.1 Filão 10 (Filão Piritas) e Filão 11}

O Filão Piritas foi um dos primeiros corpos de minério a ser explo rado intensamente no início da lavra da Mina de Camaquã, devido ao elevado teor de ouro. A superfície, tem comprimento observado de 150 metros, sendo truncado a NW pela Falha Piritas. A direção média é N $55 \mathrm{~W}$ e o mergulho varia entre 60 e $655^{\circ} \mathrm{SW}$. No nível 100 foi desenvolvido em galeria, numa extensão de 95 metros com dire ção média $\mathrm{N} 70 \mathrm{~W}$ e mergulho $60^{\circ} \mathrm{SW}$.

Algumas ramificações são observadas mesmo à superfície, mas a mais importante é a do nível 100. No nível 200, a direção média é $\mathrm{N} 75 \mathrm{~W}$, podendo apresentar mergulhos invertidos da ordem de $70^{\circ} \mathrm{NE}$ nos trechos mapeados. As espessuras deste veio são variáveis entre os limites 0,2 e 2 metros.

O filão foi lavrado sòmente no Conglomerado Superior e acima do nível 200 , restando ainda os trechos no Conglomerado Inferior. Trabalhos de pesquisa já efetuados no nível 200 revelaram a continuidade deste filão em profundidade (Fig. 23).

O Filão 11 acompanha o Filão Piritas, embora sem expressão à super fície. Nos níveis 0 e 100, foi desenvolvido por galeria de distrito, sendo lavrado em conjunto com o Filão Piritas, no bloco acima do nível 200 (Fig. 23).

\section{3.2.2 Filão 12}

Sob a designação de Filão 12 foi englobada uma zona fortemente minera lizada numa faixa de 7 a 10 metros de largura, que abrange veios rami ficados não individualizados. Estes veios foram parcialmente lavrados 
nos niveis 200, 300, 400 e 500; acima do nível 100 não foram desen volvidos e pesquisados, havendo entretanto evidências de continuidade até à superfície.

Êstes filões não foram desenvolvidos até ao Arenito Inferior. Têm continuidade em profundidade e, a julgar pelos resultados de sondagem obtidos, o limite SE e em profundidade deve ser irregular e não acom panha necessáriamente o contato Conglomerado Inferior - Arenito In ferior.

A direção destes veios varia de $\mathrm{N} 40$ a $\mathrm{N} 60 \mathrm{~W}$ e os mergulhos entre 50 e $85 \circ \mathrm{SW}$. As espessuras médias individuais variam entre 0,15 até 1,10 metros. As observações efetuadas em todos os níveis são as seguintes:

Nível 100 acima do nível 100 os filões não foram desenvol vidos e pesquisados;

Nível 200 e $300 \quad \ldots$ no nível 200, não há pilarés acima da ga leria principal tendo sido parcialmente lavrado. No nível 300, o mapeamento geológico em galeria de distrito é completo, demonstrando a existên cia de, pelo menos, 3 veios em ramo, divergindo de um tronco comum junto à Falha Piritas.

Nível 400 a extensão mineralizada é de 150 metros até o contato com o Arenito Inferior. A altura do perfil 18, há bifurcação em dois ramos que atra vessam o Arenito Inferior. Há desenvolvimento intenso de múltiplos filetes, brechamento e dis seminação de sulfetos.

Nível 500 nāo foi feito mapeamento geológico, embora a zona mineralizada tenha sido desenvolvida numa exten são de 120 metros. 


\section{3.2.3 Outros Filóes}

Alguns filões existentes principalmente nos níveis inferiores não fo ram analisados tridimensionalmente, embora exibam mineralização rica localizada e tenham sido parcialmente lavrados. Trata-se de corpos com desenvolvimento vertical limitado, ou então, imperfeita mente conhecidos. Nesta categoria estão incluidos os filões 20, 21, 22 e 24, além de dezenas de corpos, não assinalados, que represen tam, de preferência,filões de preenchimento de juntas de tração pena das, associadas às falhas principais (Fig. 23 , perfil 7). Estes cor pos normalmente têm desenvolvimento limitado e são formados, via de regra, por minério maciço e rico. 


\section{XII. - MINERALOGIA}

A té a presente data, o único trabalho que descreve, com pormenores, a mineralogia da Mina de Camaquã, é o de Leinz e Almeida (1941), embora citações parciais tenham sido feitas nas publicaçōes de Teixeira (1941) e Costa Filho (1944).

No presente trabalho, os estudos efetuados por métodos de difração de raios $\mathrm{X}$ e microscópicos, especificamente, exame de secções po lidas e lâminas delgadas, confirmaram a existência dos minerais descritos anteriormente, além de novos minerais, permitindo também a discriminação de diversas gerações de uma mesma espécie. Deve-se mencionar ainda, que as ubservaçōes microscópicas feitas, em pelo menos cincoenta seç̧ōes polidas e quarenta secções delgadas, não revelaram a existência de azurita, descrita por Leinz e Almeida (1941).

O minério apresenta minerais metálicos hipógenos e supérgenos. Os hipógenos são pirita, calcopirita, bornita, calcosita e hematita. 'Os minerais supérgenos são calcosita, hematita, covelita, antlerita, brochantita, crisocola, malaquita, cobre nativo e cuprita.

Os minerais de ganga primários incluem apenas os formadus juntamente com o minério e são: quartzo, barita, clorita e calcita. Os minerais de ganga secundários são constituídos por produtos de alte ração hidrotermal, tais como sericita, caolim, clorita, limonita e pirita. Quartzo, feldspatos, clorita e sericita, em parte são remanes centes de fragmentos de rochas encaixantes, parcialmente substituídos ou englobados pelos minerais de minério.

$$
\text { XII .1 Pirita }\left(\mathrm{FeS}_{2}\right)
$$

Os estudos microscópicos efetuados, per mitiram identificar pelo me nos duas gerações de pirita durante a formação dos filões, sendo de signadas por pirita $x$ e $\pi$. 
A pirita I é encontrada em todos os níveis das Minas S. Luiz e Uruguai, constituindo juntamente com a calcopirita, a maior parte do minério primário. Na maioria das vezes, encontra-se associada á calcopirita, bornita e quartzo. Costuma ser bem cristalizada, exibindo contornos cúbicos piritoedrais. Outras vezes apresenta formas arredondadas, angulosas, irregulares ou corroidas, dependendo do estágio de subs tituição por outros sulfetos. Nas zonas de minério disseminado, por vezes também ocorrem agregados de pirita com contornos irregulares, porosos, esqueléticos e corroidos. As dimensões dos cristais de pirita podem variar de 1 milímetro ao máximo de 2 a 3 centímetros, mas ao microscópio também são identificadas partículas de poucas micras. A pirita é mais frequentemente observada nas paredes externas dos veios, onde seus cristais, associados a quartzo, formam agrupamentos em bandas, cujas espessuras variam de poucos milímetros a alguns centímetros. As dimensões dos cristais em uma mesma faixa são aproximadamente constantes, mas podem ocorrer mudanças conside ráveis em bandas diferentes. Nesses leitos foram observadas variações na mineralização por cobre, havendo alternância de bandas ricas em calcopirita, calcopirita-bornita e calcosita.

A disseminação irregular de pirita nas rochas encaixantes dos veios constitui outro tipo de ocorrência. Os cristais, neste caso, são de dimensōes variáveis, achando-se dispersos nos espaços intergranula res de conglomerados e arenitos, ou agrupados em massas irregula res. Outras vezes, a pirita disseminada está associada aos grânulos de composição granítica, apresentando então dimensões extremamente reduzidas. Além da ocorrência nas paredes encaixantes dos veios, encontra-se disseminada em minérios primários e secundários dos veios, associada a calcopirita, bornita, calcosita, hematita, quartzo e barita Seus cristais ocorrem dispersos em porções maciças do mi nério, sendo englobados preferencialmente por calcopirita, bornita e calcosita. 
Em quase todas as secções polidas, a maior parte dos cristais de pirita acha-se extremamente cataclasada e corroida, embora muitas vezes, conserve o idiomorfismo primitivo (Fotos $10 \mathrm{e} 11$ ).

As fraturas constituem densa rede irregular e, por vezes, seguem os planos latentes de clivagem do mineral (Foto 10 ). Essas fraturas são preenchidas por calcopirita e, mais raramente, por bornita e calcosita, indicando substituição ativa de pirita por esses minerais (Fotos 10, 11 e 12). Em algumas amostras da Mina Uruguai foi, também, observada substituição por hematita especular. A ação cataclástica ativa e a substituição por calcopirita, bornita e hematita, são evidenciadas pelas texturas em veio, cataclástica (Fotos 11 e 12), bomba explodida, em mosaico e poiquilítica. Esta última é resultante da substituiçáo e impregnação interna da pirita por pequenas massas de calcopirita

No minério das zonas supérgenas das minas Uruguai e S. Luiz, foram observadas em agregados as relaçoes texturáis entre calcopirita, pirita, bornita, calcosita e covelita. Notou-se que os cristais de pirita comumente apressentam uma borda de reação, constituida preferencial mente por calcopirita (Foto 14 ), às vezes por bornita ou calcosita e raramente por covelita. A sequência completa, no entanto, evidencia um núcleo central de pirita com fraturas; externamente, há um envoltó rio de calcopirita, invadindo as fraturas, e outro mais externo e con cêntrico, de bornita, que por sua vez é substituida por calcosita. Em amostra do nível 500 da Mina Uruguai, alguns cristais de pirita também apresentam uma pequena auréola de covelitá, sendo o conjunto envolvi do por bornita.

As piritas da segunda geração foram identificadas na Zona Piritas da Mina Uruguai, onde juntamente com a calcopirita II , acham-se dis persas em filetes e veios centimétricos constituidos por barita e quartzo.

As características morfológicas e ópticas observadas não diferem daquelas já descritas para as piritas da primeira geração. Nas amostras estudadas notou-se que, via de regra, os cristais estäo pouco fraturados, sendo normalmente substituídos por calcopirita II. 


\section{XII . 2 Calcopirita $\left(\mathrm{Cu} \mathrm{FeS}_{2}\right)$}

A exemplo da pirita, também foram identificadas duas gerações de calcopirita que, neste trabalho, serão designadas por calcopirita I e II.

A calcopirita I é o mineral primário mais abundante. Ocorre em todos os níveis e pode, também, ser encontrada nas partes superiores da Mina, como remanescentes de fenômenos de alteração e oxidação. A calcopirita I dos veios é geralmente maciça e sua granulação varia de 1 a 3 milímetros. Menos frequentemente apresenta-se disseminada em pequena quantidade nas zonas marginais dos veios, associada à pirita I. Neste caso, apresenta-se em finos cristais disseminados, de dimensões às vezes menores do que 0,014 milímetros, formando corpos irregulares que envolvem fragmentos dos componentes das rochas encaixantes.

$\mathrm{Na}$ forma maciça apresenta-se em grãos puros, mas às vezes é espon josa, extremamente pontilhada por minerais de ganga e corpos submili métricos de bornita.

E constituinte comum de brechas, vênulas e filetes, estes de espessuras milimétricas.

A calcopirita I apresenta fraturamento irregular, mas não tão intenso quanto a pirita I. Essas fraturas, sempre preenchidas por minerais de ganga posteriores, foram os condutos por onde se deu a substituição de calcopirita por bornita e, especialmente na Mina Uruguai, a invasão de hematita especular e gangas relacionadas.

A calcopirita apresenta substituição intensa preferencialmente por bornita. Em escala subordinada é substituida por calcosita e hematita e, muito raramente, por covelita. A observação das relaçōes mais íntimas entre êsses minerais indica uma gradação, a calcopirita sendo substituida por bornita e esta por calcosita; esta pode também substituir as duas primeiras ao mesmo tempo. 
As relações texturais entre calcopirita, hematita primária e bornita são mais evidentes na Mina Uruguai - Zona Piritas, onde hematita especular e gangas substituem ativamente a calcopirita, quer só ou, mais comumente, associada à pirita e bornita. Corpos irregulares esfarrapados e corroidos de calcopirita e bornita ocorrem substitui dos e envolvidos, parcial ou totalmente, por cristais ripiformes de hematita e ganga quartzosa.

As relaçöes texturais entre calcopirita e hematita podem ser obser vadas nas Fotos 19 e 20 .

A calcopirita da segunda geração foi identificada na Mina Uruguai, principalmente na Zona Piritas, onde, juntamente com piritas I e II, bornita e hematita primária, constituem parte considerável do miné rio existente nessa zona.

A forma mais usual de ocorrência da calcopirita II é em bandas mili métricas ou centimétricas, intimamente associada à bornita e hẹmati ta.

Muito frequentemente, veios centimétricos zonados podem ser observados, caracterizados por alternâncias de bandas paralelas constitui das do centro para a periferia, de:

a) barita, quartzo, pirita II e calcopirita II esparsas,

b) hematita especular primária,

c) calcopirita II,

d) hematita especular.

Uma associação também comum com pirita II é notória. Neste caso, como já foi dito, formam corpos milimétricos esparsos em filetes e veios constituidos por quartzo e barita. 
Os estudos microscópicos efetuados indicam que a calcopirita II substitue intensamente todos os minerais metálicos e minerais de ganga anteriores, em particular bornita e hematita. A substituiçāo de bornita por calcopirita é claramente demonstrada por várias feições texturais: bordas de reação formadas por calcopirita substituindo bornita, lame las de calcopirita ocupando planos de clivagem da bornita e corrosäo intensa de corpos irregulares de bornita englobados por calcopirita (Fotos 15, 16, 17, 25 e 26).

As relações íntimas entre calcopirita e hematita são extremamente bem demonstradas pela presença de:

a) cristais de hematita esparsos na massa de calcopirita $I$,

b) fragmentos de minério mais antigos, constituidos por hematita, gangas e sulfetos, todos corroidos e englobados por calcopirita (Fotos

$$
\text { XII. } 3 \text { Bornita }\left(\mathrm{Cu}_{5} \mathrm{FeS}_{4}\right)
$$

A bornita, depois da calcopirita e pirita, ê o sulfeto mais frequente na Mina de Camaquã. Sua distribuição é ampla, sendo encontrada desde os níveis mais profundos, entre 300 e 400 metros de profundidade na Mina Uruguai, até à zona oxidada.

As observações efetuadas em subsolo e também ao microscópio indicam a existência de bornita hipógena e supérgena.

Ocorre associada com calcopirita, pirita, covelita, hematita, limonita e minerais de ganga, na forma de bolsões em veios; como veios espês sos, restritos ao nível 500 da Mina Uruguai; disseminada nas rochas encaixantes, onde preenche os espaços intergranulares, e também como constituinte de brechas mineralizadas.

Apresenta-se normalmente na forma maciça ou granular. 
A exemplo do que foi observado para a calcopirita, a bornita substitue calcopirita e pirita, sendo por sua vez substituida por calcosita, cove lita e hematita. Apresenta também frequentes fraturas que constituem zonas de penetração e substituiçãa por calcosita, covelita e hematita. Em relação à calcopirita, a bornita é menos ativa na substituição da pirita.

Associaçōes mais íntimas de bornita e pirita não são muito frequentes. Algumas vezes, minúsculos cpistais de pirita são encontrados dispersos em massa de bornita, mostrando contornos extremamente corroidos. Mais frequente é a penetração de bornita, ao longa das fraturas de piri ta, embora pareça ser um processo indireto, pois, na realidade, a bornita substitue a calcopirita jâ existente nessas fraturas.

As relações entre bornita e calcopirita já foram aventadas anterior mente. A bornita é normalmente substituida por calcosita e covelita. Em geral a alteração se processa ao longo de fraturas e contatos com minerais de ganga, sendo essas relações evidenciadas por texturas aureolares e poiquilíticas, já descritas. Quando ao longo de fraturas, a calcosita substitue concomitantemente bornita e calcopirita.

$$
\text { XII .4 Hematita }\left(\mathrm{Fe}_{2} \mathrm{O}_{3}\right)
$$

Muito antes da abertura total da Mina Uruguai, a hematita foi descrita por Leinz e Almeida (1941, págs. 36, 39 e 41), como mineral residual resultante da substituição de calcopirita e bornita por calcosita e cove lita. Entretanto, a análise dos filöes da Mina Uruguai revela que a hema tita também é um dos minerais primários, que ocorre em larga escala em todos os níveis da Mina Uruguai, de preferência na Zona Piritas, onde chega a formar veios com espessuras de até um metro. Este tipo de hematita especular foi designado de hematita $I$. 
Apesar de predominar constituindo veios e filetes submilimétricos, a hematita I apresenta ampla distribuição na forma disseminada e como constituinte de brechas. Apresenta-se em cristais isolados, idiomórficos e alongados, de forma tabular, ripiforme ou prismática, bem formados ou em agregados de vários indivíduos entrelaçados (Foto 18). Suas dimensões máximas atingem até 0,35 milímetros segundo o alongamento máximo, e diâmetros médios variando de 0,01 a 0,04 milímetros.

Os veios hematíticos observados na Mina Uruguai, frequentemente, exibem estrutura bandada na forma de faixas quartzosas e hematíticas alternadas, paralelas às direções principais dos veios. As primeiras são constituídas por quartzo hidrotermal microgranular, com espes suras entre 1 e 6 milímetros, enquanto as bandas hematíticas têm espessuras milimétricas a centimétricas. A natureza micácea da he matita especular aqui descrita e as dimensões submilimétricas dos cristais ocasionam corrugamentos e, mesmo, uma estrutura xistosa nos veios, devido ao arranjo planar desses cristais. A hematita apa rece também substituindo calcopirita I, bornita e pirita I.

Frequentemente, a hematita é observada dispersa na calcopirita I e bornita, quase sempre a certa distancia de fraturas desses mixerais, que seriam os dutos alinentadores por onde se infiltraram ganga quart zosa e hematita associada. Outras vezes, a hematita ocorre disseminada em ganga cuartzosa, formando micrólitcs dispersos caoticamente ou suboricritados.

Na maior parte das amostras de minério primário a hematita I substitue ativamente os sulfetos mais antigos, norread mente calcopirita, bornita e pirita (Fot.19 e 20). As evidências texturais, observadas macroscopica. mente e em seções polidas, mostram que calcopirita e bornita formam corpos submilimétricos e miximétricos esfarrapados e corroidos, espar sos em ynassa de cristais finos de hematita. 
O arranjo dos cristais de hematita, à volta dos corpos remanescentes, demonstra movimentação e fluxo do fluído mineralizante, com orienta ção subsequente das ripas de hematita, ocasionando assim uma textu. ra fluidal, mito frequente. Esste envolvimento, não só é observado com os sulfetos, calcopirita, hernita e pirita, como também com frag mentos e grânilos das rochas encaixantes, arenito e conglomerado, sendo notória a substituição a partir dos bordos (Fotos 22 e 23).

Frequentemente, os espaços intergrantalares são preenchidos total mente fror hematita maciça, formando uma rede densa. Outras vezes, a matriz da rocha encaixante mostra-se totalmente substituida, deixan do um mosaico formado sormente por agyegados imbricados de vários grãos de quartzo envolvidos por hernatita.

Os fragrientos englobados de arenito e conglomerado, via de regra, mostrar o cimento oniginal totalmente substituido por clorita e os grãos de quartzo erabebidos nessa matriz, o que confere a cor intensa. esverdeada da maior parto dos fragmentos de rocha encaixante associa. dos à hernatita $\mathrm{J}$.

O segundo tipo de herratita, desjgnada hematita II, constitue produto de oxidação e substituição de sulfetos primários, estando na maior parte das vezes associada à calcosita, bornita e calcopirita. As obser vações em secçöes polidas revelaram que, como produto residual de alteração e substituição, a hematita spresenta-se com hábito maciço e irregular, mas com aspecto esponjoso e esquelético, muito diferente da hematita primária.

Particularmente nass zonas superiores das minas $S$, Luiz e Uruguai, hematita esponjosa foi obsorvada muito frequentemente, associada i bornita e calcopirite e, sm mairor frequência, 'a calcosita. A forma usual de ocorrência é segundo uma auréola que envolve não só o con junto maciço constituido por calcopirita e bornita: mas também calco sita. Esses sulfetos mostram-se corroidos no limite da franja, haven do uma zona de transição, especialmente no caso da calcosita, com textura mirmequítica ber clesenvolvida, na quol a calcosita e hematita 
coexistem. Em amostras de minério oxidado da Mina S. Luiz, a hema tita acha-se associada'a calcosita, cuprita e quartzo idiomórfico, como mineral de ganga. A calcosita mostra-se completamente esfar rapada nas porçōes onde a alteração foi maior, dando um produto re sidual de hematita esqueletiforme, em rede densa e irregular; há também disseminação intensa de cuprita, que envolve e preenche os espaços intergranulares. Independente desta associação, a calcosita acha-se completamente corroida e, juntamente com hematita, forma texturas mirmequíticas complexas (Foto 29).

\section{XII .5 Calcosita $\left(\mathrm{Cu}_{2} \mathrm{~S}\right)$}

A calcosita é um dos sulfetos com distribuição ampla nos níveis supe riores das minas Uruguai e S. Luiz e Zona Intermediária, onde forma a maior parte do minério da zona supérgena. Sua presença foi também constatada em bolsões isolados nos níveis 500 e 400 da Mina S. Luiz, no nível 500 da Mina Uruguai, onde ocorre extremamente disseminada e também em níveis profundos da Mina Uruguai, entre 300 a 400 me tros de profundidade.

A calcosita apresenta forma maciça ou granular, sendo difícil estimar, macroscopicamente, as dimensões dos grãos. Testes de corrosão, efe tuados em secções polidas com $\mathrm{HNO}_{3} 1: 1$; demonstram a existência de grãos imbricados com contornos irregulares e comprimentos máxi mos de até 2,5 milímetros. A geminação lamelar, já notada em secções polidas, ficou mais evidenciada após a corrosão, ao lado de cliva gens típicas, extremamente bem desenvolvidas.

Na maior parte das amostras de minério foram constatados dois tipos de calcosita. O primeiro, de côr azul clara, apresenta birrefl etância forte e uma segunda variedade, cinza azulada, possui anisotropismo fraco. Frequentemente, os dois tipos coexistem em lamelas alternadas. 
A calcosita está intimamente associada à pirita, calcopirita, bornita, covelita, cuprita, quartzo, óxido de ferro e cobre nativo; substitui ativamente calcopirita, bornita e covelita, além de pirita, em escala menor.

Em amostras dos níveis 500 das minas S. Luiz e Uruguai e algumas da Zona Intermediária, notou-se que a calcosita contém remanescentes irregulares e corroidos de cristais de pirita, cuja substituição é feita ao longo de planos de fraturamento e direções cristalográficas. Nos níveis superiores, especialmente na zona de oxidação, a pirita não está tão frequentemente associada à calcosita.

As relações texturais com a bornita e calcopirita são notórias e mais frequentes na zon a de oxidação. Em amostras de maior profundidade, manchas ou corpos irregulares de bornita e calcopirita são encontrados dispersos em massa de calcosita, formando ilhas. Algumas vezes, os corpos de bornita apresentam-se internamente pontilhados por fragmen tos de calcosita, demonstrando textura poiquilítica bem desenvolvida.

Ao nível 500 da Mina Uruguai, em filōes de bornita maciça e também em minério disseminado, a calcosita substitui e forma bordas de rea ção na bornita.

Nos níveis superiores, bordas de reação são extremamente bem desen volvidas, notando-se frequentes auréolas de calcosita nos sulfetos mais antigos; às vezes, encontra-se uma sucessão de pirita fraturada, envol vida por calcopirita e bornita, sendo o conjunto todo aureolado por cal cosita.

Particularmente na Zona Intermediária, Filāo Barnabé e Galeria dos Belgas, a calcosita forma filetes que cortam a bornita e calcopirita, originando textura em veio muito característico; essa substituição é feita ao lon go de bordos ou, preferencialmente, nas fraturas, por onde a calcosita invade e substitui os sulfetos primários (Foto 28). 
A associação calcosita-covelita é pouco desenvolvida nos níveis 500 e 400 das duas Minas, onde a covelita ocorre apenas em corpos punti formes, dispersos na massa de calcosita. Na zona de oxidação, a covelita foi observada substituindo a calcosita ao longo de direções cristalográficas, originando lamelas alternadas dos dois minerais .

1

Ainda na Zona Intermediária, foram notados corpos aciculares e bastões de covelita orientados segundo direções cristalográficas para lelas da calcosita.

Na zona oxidada, a calcosita acha-se associada à cuprita, hematita, limonita, cobre nativo e quartzo. Sob os efeitos de oxidação, a calco sita apresenta corpos irregulares de cobre nativo, dispersos na mas sa (Foto 24 ); evidencia ainda corrosão intensa e associação com he matita esponjosa e esquelética, originando então textura mirmequítica complexa, já referida anteriormente. Na franja de alteração, constitui da por remanescentes de hematita e calcosita, desenvolve-se abundante quantidade de cuprita terrosa, além de quantidades subordinadas de goethita. Estas associações foram observadas em amostras do Fi lão S. Luiz, Galeria dos Belgas e zona disseminada do nível 500 da Mina Uruguai. Também foram encontradas associaçōes com malaquita, quer em lamelas, ou preenchendo fraturas da calcosita.

\section{XII .6 Quartzo $\left(\mathrm{SiO}_{2}\right)$}

A observação das relações texturais do minério mostra claramente a presença de uma geração antiga de quartzo muito fino associado a piri ta, e que foi designado de quartzo I. Este tipo de quartzo faz parte dos veios e frequentemente constitui a parte lateral dos filões, originando um zonamento lateral. O quartzo apresenta aspecto maciço e cor acin zentada; ao microscópio, foram observados cristais prismáticos, idio mórficos, alongados ou com contornos hexagonais, imbricados entre si, além de formas xenomórficas, muito comuns. Os cristais prismáti cos, na maior parte das vezes, estão dispersos em abundante massa 
constituida por cristais de quartzo extremamente irregulares, corroi dos e imbricados, formando uma textura granoblástica, havendo evi dências de substituição por soluções posteriores. As dimensões des tes cristais variam de 0,5 a 0,01 milímetros; com granulação mais frequente em torno de 0,5 milímetros. Frequentemente estes cristais englobam fragmentos de rochas encaixantes, originando auréolas com textura fluidal incipiente.

Em associação íntima com sulfetos posteriores à pirita, nomeada mente calcopirita e bornita, é notória a presença de quartzo branco, provavelmente de uma nova geração que foi designado de quartzo II. Faz parte dos veios e zonas brechóides, onde aglutina fragmentos e sulfetos; também forma filetes que podem ou não cortar calcopirita, bornita e quartzo dẹ geração mais antiga.

Este tipo de quartzo pode ocorrer em cristais idiomórficos, prismá ticos, alongados ou hexagonais, mas também em grãos xenomórficos ou imbricados, formando textura granoblástica.

O quartzo leitoso pode englobar e formar auréolas à volta de cristais extremamente finos de quartzo de provável geração anterior que, às vezes, estão cataclasados, corroidos e imbricados. As dimensões médias dos grãos são da ordem de $0,04 \mathrm{~mm}$, mas podem atingir até $3 \mathrm{~mm}$.

A ganga quartzosa associada à mineralização hematítica da Zona Piri tas - Mina Uruguai, foi chamada de quartzo InI. Forma corpos irregu lares ou filetes milimétricos a centimétricos que se alternam com bandas hematíticas. Os cristais de quartzo têm dimensōes inferiores a 2 milímetros, são idiomórficos ou xenomórficos e definem uma textura granoblástica.

Os minerais de ganga da última fase de mineralização, representados por calcita e barita, comumente estão associados a quartzo que foi de nominado de quartzo IV. Este tipo de associação ocorre mais frequen temente em filetes de poucos milímetros de espessura que cortam os 
minerais de minério e gangas anteriores. Estes corpos são caracteri zados pelas associações calcita-quartzo IV ou quartzo IV - barita com ou sem calcopirita II e pirita II.

Os cristais de quartzo são idiomórficos, algumas vezes xenomórficos, apresentando dimensões entre 0,13 a $0,77 \mathrm{~mm}$. Grãos de quartzo com dimensōes entre 0,01 e $0,7 \mathrm{~mm}$, corroidos, fraturados e preenchi dos por minério secundário, foram também observados em associação com cuprita e calcosita da zona oxidada.

\section{XII . 7 Clorita}

A clorita ocorre em associação frequente com sulfetos e minerais de ganga nos diferentes tipos de minério. Pode estar englobada por outros minerais, dispersa na massa dos constituintes dos filoes ou nas pare des dos veios e rochas encaixantes.

Observaçōes em lâminas delgadas e secções polidas demonstram a existência de cloritas residuais das rochas encaixantes, bem como resultantes da ação de soluções hidrotermais.

A ocorrência de clorita nos filões da Mina S. Luiz é pequena em relação à Mina Uruguai. Nos níveis 500, 400 e 300 da Zona Piritas, é particularmente abundante em zonas brechadas, encaixantes e pare des dos veios, conferindo característica cor verde escura às rochas. A transição minério - encaixante nos filões e vênulas, é frequente mente feita diretamente por clorita, que substitui totalmente a matriz antiga e embebe grânulos líticos e cristais de feldspatos e quartzo, deformados e cataclasados.

A clorita forma agregados microlíticos, fibrosos irregulares, e cris tais prismáticos radiados ou foliados, com dimensões até $0,8 \mathrm{~mm}$. Em minério da Zona Feliciano e Oscarino, foram observados cristais 
de clorita formando uma massa feltrosa, constituida por micrólitos alongados e fibrosos, com porcentagem subordinada de cristais prismáticos radiados. Frequentemente, há também associação com micrólitos de quartzo, em forma de prismas alongados, que em con junto com a clorita, conferem textura incipientemente fluidal ao minério.

\section{XII . 8 Barita $\left(\mathrm{Ba} \mathrm{SO}_{4}\right)$}

A barita tem distribuição ampla no distrito. Ocorre mais frequente mente como constituinte principal de filōes, preenchendo fraturas subsidiárias nas vizinhanças de falhas, ou como material agregante de brechas quartzosas ou sulfetadas.

Observações superficiais e em subsolo demonstram que suas concen trações são maiores nas zonas em que os veios fazem transição entre o Conglomerado Vargas e os arenitos Superior e Inferior. Esta zona de transição coincide, via de regra, com os limites extremos da mineralização econômica, em que os teores em cobre diminuem signi ficantemente. Particularmente na extremidade sudeste dos filões Bar nabé, S. Júlio, Esperança e fillōes da Zona Piritas, podem ser encontrados veios de barita com espessuras de poucos decímetros. A tran sição entre as partes mineralizadas com cobre e estéreis, se faz ra pidamente. Juntamente com quartzo, a barita forma a maior parte dos veios na zonas Potreiros, Oscarino, Feliciano e Cêrro das Tunas. $\mathrm{Na}$ extremidade noroeste do distrito, a mineralização a sulfeto é subs tituida por minerais de ganga, sendo a barita um dos componentes das extremidades estéreis.

Ao microscópio, a barita é incolor ou de cor parda amarelada, quando pigmentada por óxidos de ferro. Os cristais são tabulares, anhedrais ou euhedrais, muitas vezes geminados polissinteticamente. Suas dimen sões podem atingir até $5 \mathrm{~cm}$. 
Em amostras das Zonas Oscarino e Feliciano, foram observadas formas tabulares, finamente dispersas, associadas a quartzo muito fino e idiomórfico, bem como fragmentos de rochas encaixantes extremamente cataclasadas. Inclusões de quartzo idiomórfico, individualizadas ou formando agregados ocorrem na barita. Leinz et al (1941) assinalam, também, inclusões de calcopirita em barita.

\section{XII. $9 \quad$ Calcita $\left(\mathrm{Ca} \mathrm{CO}_{3}\right)$}

A calcita é um dos minerais hipógenos que se formaram na fase final da mineralização. Ocorre preenchendo fraturas irregulares nas pa redes dos veios, como constituinte dos filóes que cortam os sulfetos e gangas anteriores. Neste caso é quase sempre acompanhada por quartzo hidrotermal microcristalino.

Calcita supérgena pode também estar presente nas partes oxidadas dos veios, envolvendo fragmentos e brechas.

\section{XII . 10 Limonita}

Com a designação de limonita (FeO HO. $n \mathrm{H}_{2} n$ ) segundo Deer (1961, pág. 124), são aqui incluidos todos os óxidos de ferro hidratados su pérgenos com distribuição ampla principalmente nas partes superio res da Mina. Estes óxidos ocorrem mais frequentemente em minério oxidado, associados a cuprita, hematita, bornita, calcosita e pirita.

A identificação petrográfica das variedades de limonita é uma tarefa difícil, devido ao caráter cristalino pobre, razão pela qual, 10 amos tras de óxidos de ferro foram investigadas por métodos de raios $\mathrm{X} \mathrm{e}$ microscópicos. Este estudo possibilitou diagnosticar em todas as amostras a presença de goethita ( $\mathrm{FeO}$. OH) e menos frequentemente a lepidocrocita (FeO. OH). 
Macroscopicamente a limonita apresentamse : formando pó avermelhado, com aspecto terroso, nas paredes das encaixantes; como massas pseu domorfas de sulfetos; e como películas acastanhadas sobre minério, gangas e fragmentos de rocha ou cimentando brechas e fragmentos de minério.

Em lâminas delgadas ocorre formando agregados amorfos, terrosos, irregulares, às vezes maciços e com coloração castanha suja.

As variedades cristalinas assinaladas, de cores castanha ou amarela "se associam à hematita, sobre a qual formam franjas. Podem, também, preencher espaços intergranulares, fraturas e capilares, nos próprios sulfetos, ou nas paredes das encaixantes.

$$
\text { XII. } 11 \quad \text { Cuprita }\left(\mathrm{Cu}_{2} \mathrm{O}\right)
$$

A cuprita foi encontrada na Mina S. Luiz, nos blocos do nível 100, a mais ou menos $15-20 \mathrm{~m}$ da superfície, em bolsões de minério oxida do e, também, em minério da Galeria dos Belgas.

A cuprita ocorre associada a calcosita, hematita, cobre nativo, quart zo e limonita, sob duas formas bem distintas: quer formando agrega dos de cristais idiomórficos ou constituindo massas avermelhadas terrosas e pulverulentas.

Em agregados idiomórficos, o reconhecimento pode ser feito macroscopi camente. Os cristais possuem contornos octaériricos, cúbicos ou dode caédricos e cor vermelha intensa, podendo apresentar fratura conchoi dal. Suas dimensões atingem até $1 \mathrm{~mm}$. Algumas vezes, a cuprita preenche "vugs" formados por cristais de quartzo idiomórficos. A forma terrosa é mais extensamente observada, estando intimamente associada a calcosita e hematita. A feição marcante desta associação, é a textura mirmequítica típica formada por calcosita e hematita, no tando-se que, a cuprita terrosa e pulvurulenta, muitas vezes, se instala nos espaços livres dessa rede formada por hematita e calcosita (Foto 29). 


\section{XII.. 12 Cobre Nativo (Cu)}

A presença de cobre nativo foi inicialmente constatada por Leinz e Almeida (1941, pág. 40), num testemunho de sondagem de vieiro de quartzo, a aproximadamente $70 \mathrm{~m}$ de profundidade. No nível $100 \mathrm{da}$ mina S. Luiz, as amostras dos blocos 101 e 102, situados entre 15 e $20 \mathrm{~m}$ da superfície, evidenciaram a ocorrência de $\mathrm{Cu}$ nativo em bolsões de minério oxidado. Este elemento nativo forma agrega dos na maior parte das vezes com calcosita e cristais idiomórficos de cuprita. Nas amostras observadas, a associação mais frequente se faz com quartzo hidrotermal, cuprita, calcosita e limonita, em amostras porosas e cavidades de minério oxidado (Foto 24).

Os cristais apresentam textura alotriomórfica e coloforme. As di mensões variam de 0,003 a $0,4 \mathrm{~mm}$.

$$
\text { XII.13 Malaquita } \quad \mathrm{Cu}_{2} \quad(\mathrm{OH})_{2} \mathrm{CO}_{3}
$$

Macroscopicamente, a malaquita pode ser identificada em minério das porções superiores da Mina, principalmente na zona de oxidação mas também em galerias dos níveis mais profundos, sujeitas à per colação de água, após sua abertura.

A malaquita forma película recobrindo os sulfetos e prenchendo fra turas já existentes, quer na rocha encaixante, como no próprio miné rio e sulfetos fraturados. Essas películas podem ter grande extensão, recobrindo paredes de galerias principalmente quando estas possuem mineralização disseminada. Muitas vezes a malaquita cimenta fragmentos das rochas encaixantes, de preferência nas zonas brechadas. Nos níveis superiores, em especial na Zona Intermediária,ela está intimamente associada à calcosita, formando uma rede emaranhada, pelo preenchimento de fraturas submilimétricas e capilares nos próprios sulfetos. Associa-se, também, à covelita, hematita, goethita e quartzo. 


\section{XII .14 Crisocola $\left(\mathrm{CuSiO}_{3} \cdot \mathrm{H}_{2} \mathrm{O}\right)$}

A crisocola também foi observada nas zonas superiores da mina, especialmente na Galeria dos Belgas e Filão Barnabé. Também foi identificada em amostras dos níveis mais profundos, provavelmente devido à infiltração de água, ao longo dos planos de falha. A crisoco la ocorre nos veios, em zonas de minério disseminado em brechas e paredes de galerias. Via de regra, apresenta-se em películas finas, cobrindo partes consideráveis das paredes de galerias atin gindo até $1 \mathrm{~mm}$ de espessura, ou então preenchendo fraturas submi limétricas.

A cor é azul celeste. O aspecto é maciço ou ocasionalmente fibroso.

$$
\mathrm{XII} \cdot 15 \text { Antlerita } \mathrm{Cu}_{3}\left(\mathrm{SO}_{4}\right)(\mathrm{OH})_{4}, \text { Brochantita } \mathrm{Cu}_{4}\left(\mathrm{SO}_{4}\right)(\mathrm{OH})_{6}
$$

A antlerita e brochantita foram observadas em antigas galerias aban donadas. A ocorrência é mais frequente na Galeria dos Belgas, Filão Barnabé e mesmo em antigos trabalhos mineiros dos níveis 200, 300 e 400 das Minas S. Luiz e Uruguai. Nos níveis mais profundos também foram assinalados.

Estes minerais formam película ou capa esponjosa nos sulfetos, normal mente na zona de oxidação e em paredes mineralizadas. Estão sempre acompanhadas de malaquita e óxidos de ferro.

A antlerita e brochantita normalmente ocorrem em íntima associação. Macroscopicamente tem aspécto de um agregado pulverulento e terroso, de cor verde clara, que recobre os sulfetos oxidados. Ao microscópio,a massa é formada por micrólitos prismáticos, alongados e pleocróicos. A antlerita e brochantita foram identificadas por técnicas de raios $X$. Ao microscópio,as duas espécies foram confirmadas, embora as propriedades ópticas sejam de difícil observação, devido à finura e aspectos filiforme e massiforme dos cristais, mesmo quando observados com objetiva de aumento grande. 


\section{XII- 16 Covelita (CuS)}

A covelita ocorre em pequenas quantidades, especialmente na zona de oxidação e de enriquecimento. Substitue ativamente a calcosita e bornita.

Frequentemente são observadas lamelas de covelita substituindo a calcosita ao longo dos planos de clivagem. (Foto 31). 


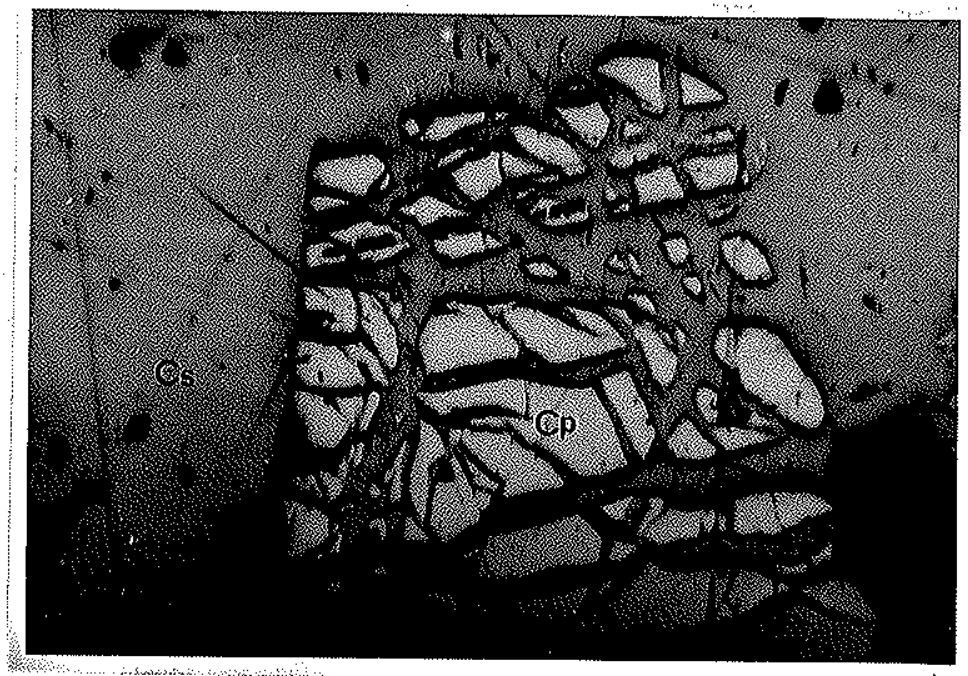

Fotomicrografia - 10 - Mina São Luiz Nive1-500. Pirita extremamente catacla sada substituida por calcosita a longo de planos cristalográficos. Nícois descruzados. Aumento 448 vezes.

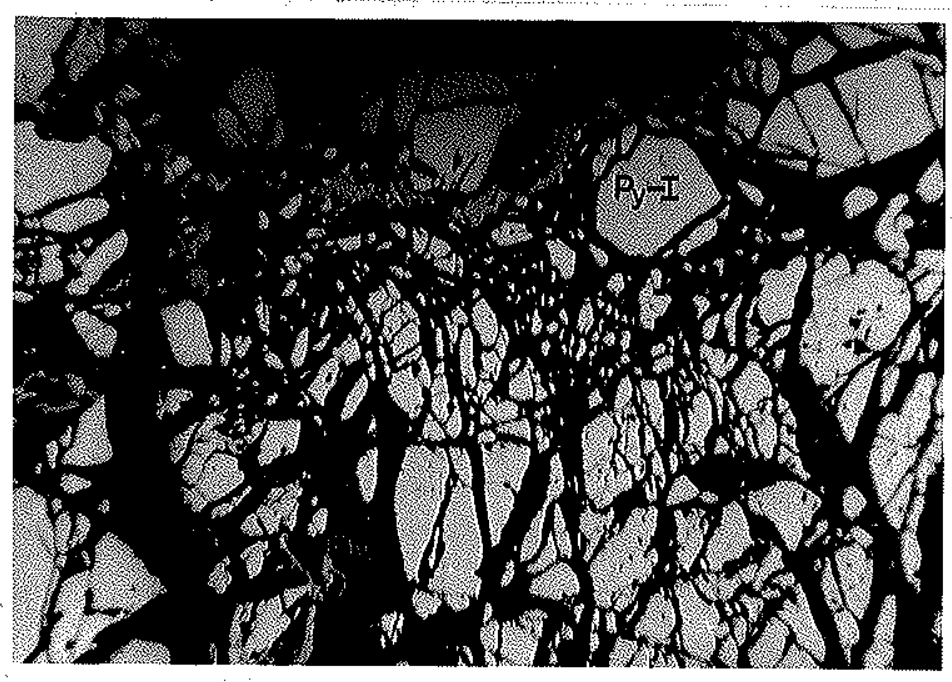

Fotomicrografia 11 - Mina São Luiz Bloco 640. Textura cataclástica em cristais de pirita. Notam-se fragmen tos residuais da substituição de pirita por bornita. os minerais de gan ga aparecem em negro.Nicois descruza dos. Aumento 448 vezes. 


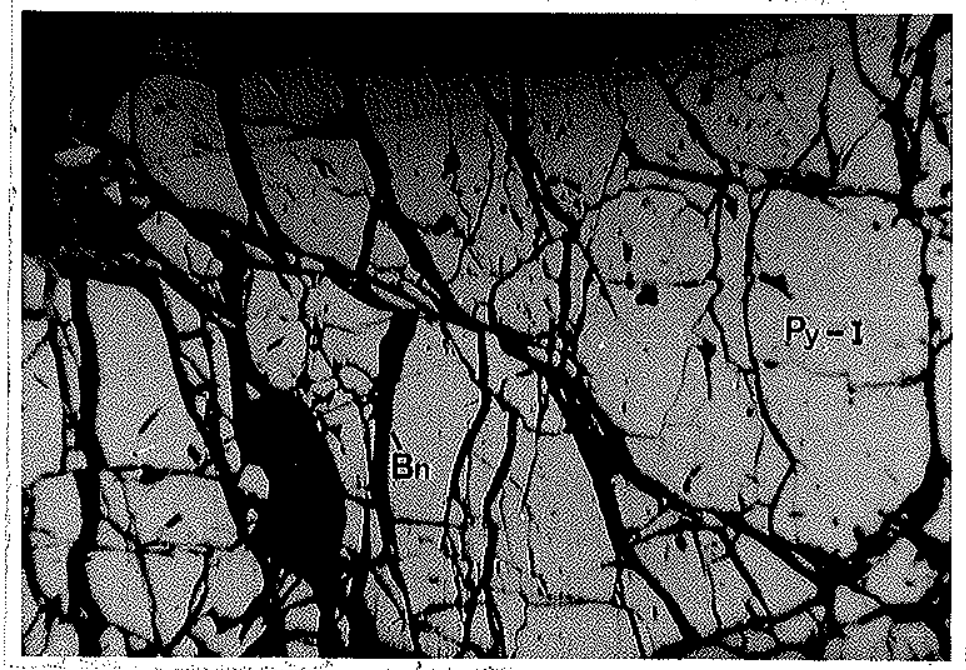

Fotomicrografia 12 - Mina São Luiz - Ni vel 600. Textura reticulada em pirita. A bornita substitui pirita e cimenta as fraturas. Nícois descruzados. Aumento 448 vezes.

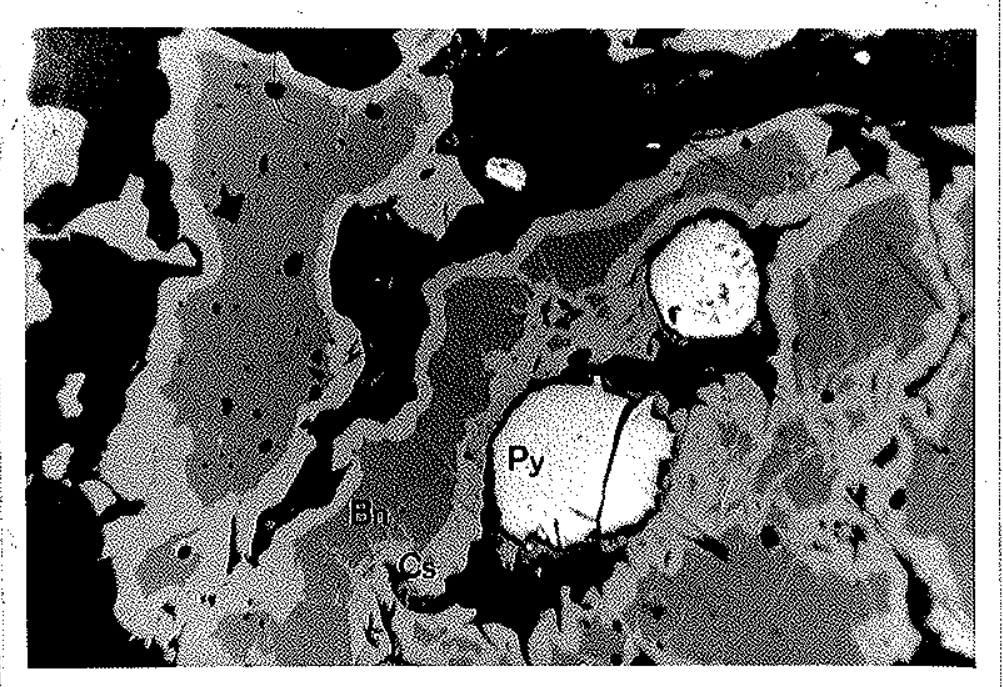

Fotomicrografia 13 - Mina são Luiz Bordas de reação da calcosita substituindo bornita. Notar substituição incipiente dos cristais de pirita. Ní cois descruzados. Aumento 875 vezes. 


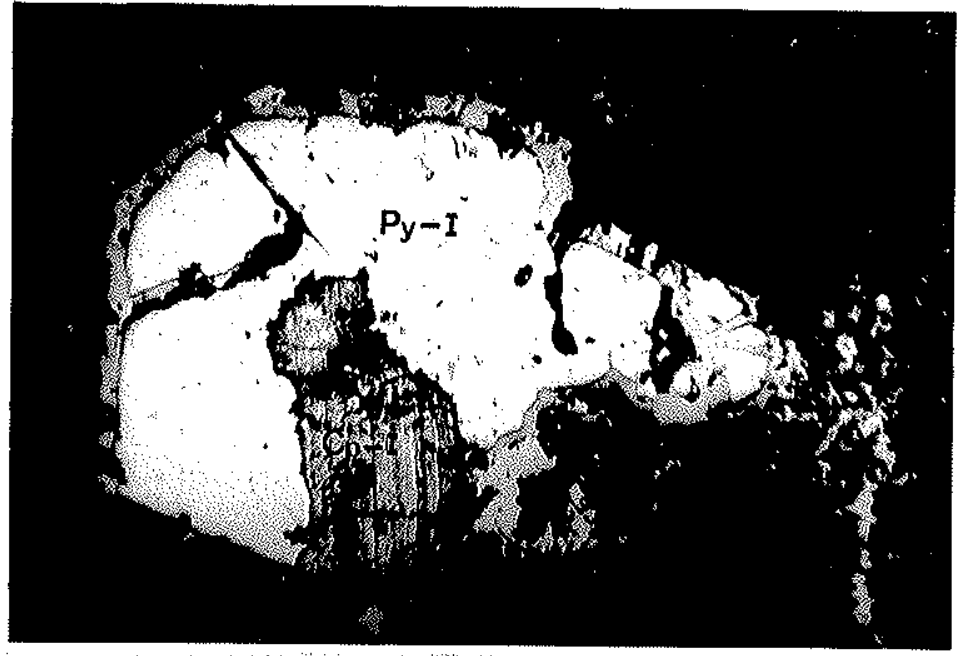

Fotomicrografia 14 - Zona intermedia ria. Borda de reação formada por cal copirita, envolvendo e penetrando p $\bar{i}$ rita. Notar também o preenchimento das fraturas por minerais de ganga. $N i$ cois descruzados. Aumento 448 vezes.

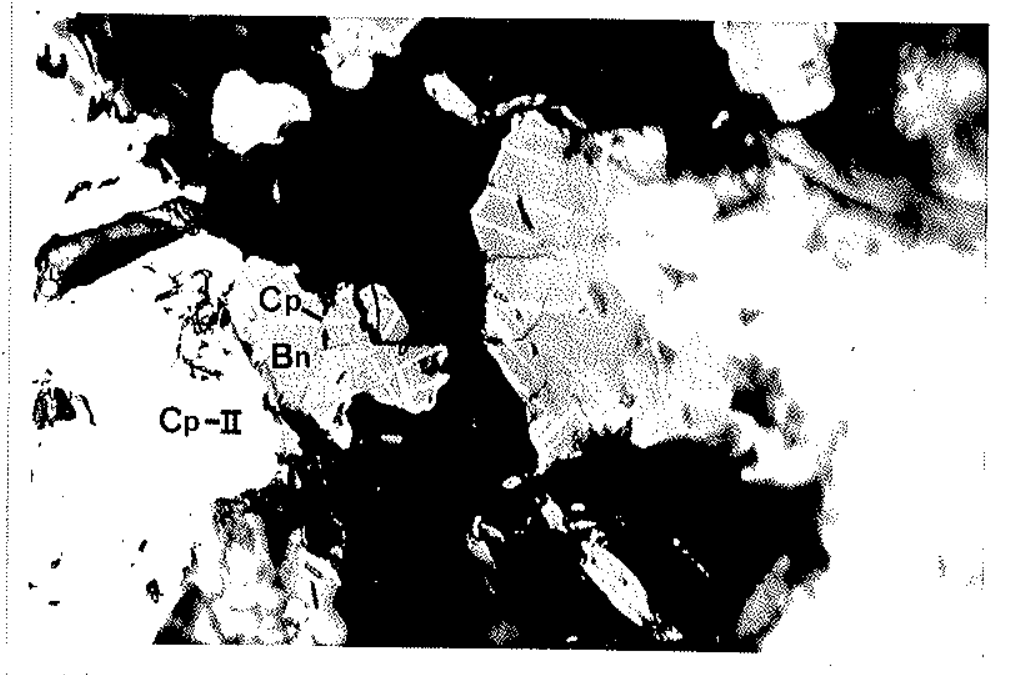

Fotomicrografia 15 - Substituição da bornita por calcopirita II, a par tir das bordas para o interior dos grãos. Notar tambêm a influência das direçöes cristalogräficas nessa substituíção. Aumento 875 vezes. 


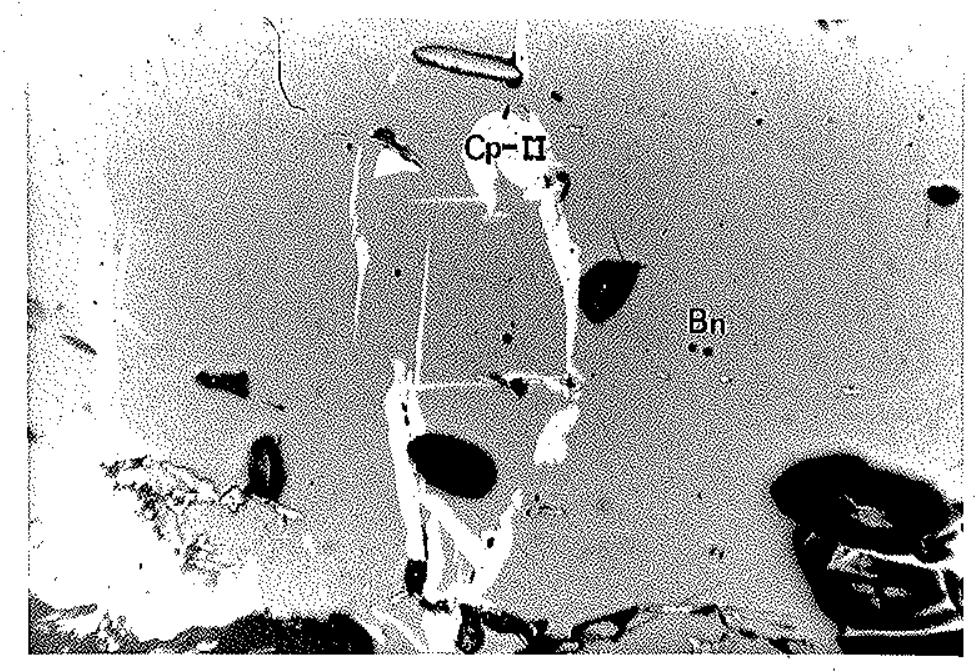

Fotomicrografia 16 - Substituição de bornita por calcopirita II, no ta-se o controle dessa substituição pelas direções cristalogrāficas da bornita. Aumento 1.428 ve zes.

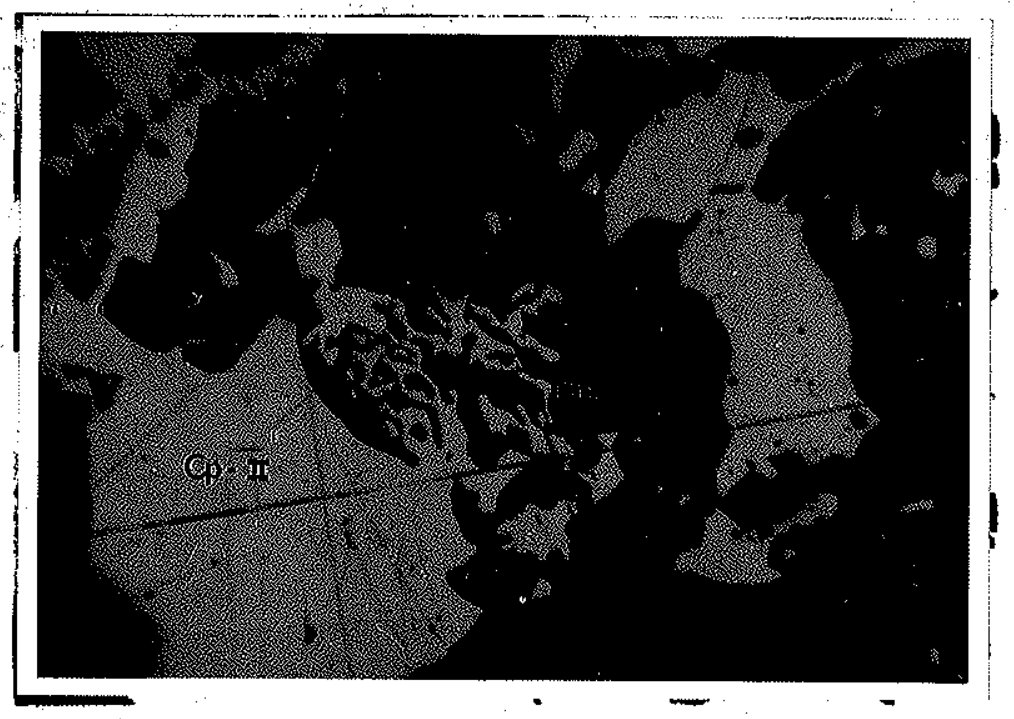

Fotomicrografia 17 - Substituição de bornita por calcopirita II, mos trando desenvolvimento incipiente de textura mirmequîtica. Estas fei ções representam um estägio inicial da textura referida. Aumento de 441 vezes. 


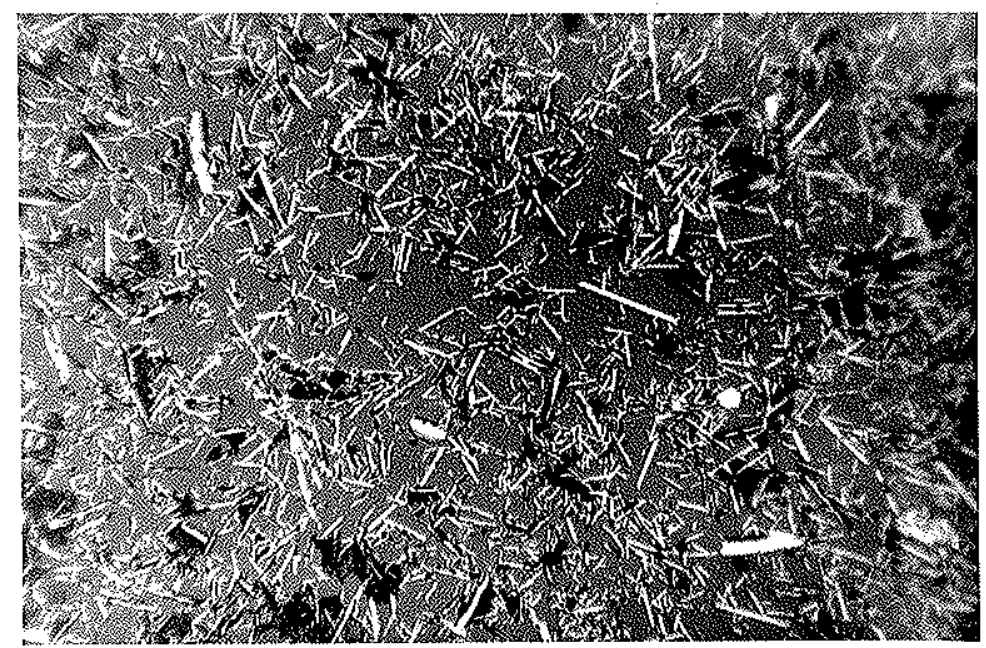

Fotomicrografia 18 - Mina Uruguai. Cris tais ripiformes de hematita esparsos em ganga quartzosa. Nícois descruzados.Aumento 427 vezes.

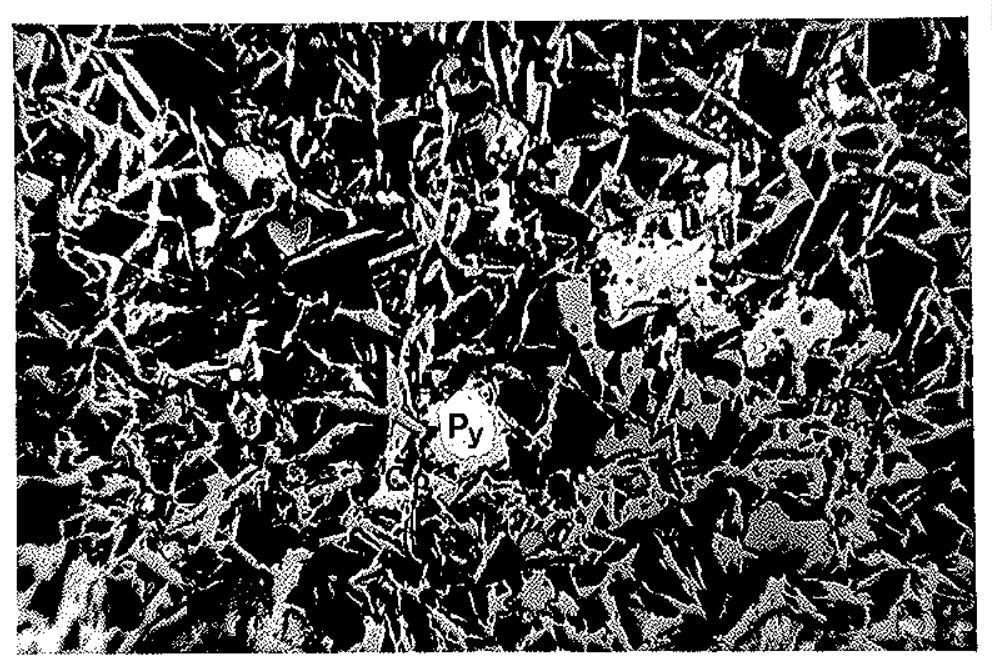

Fotomicrografia 19 - Cristais tabulares de hematita especular, formando rede an gular. Calcopirita e pirita mais antigas sofreram substituição e corrosão. Nícois descruzados. Aumento 427 vezes. 


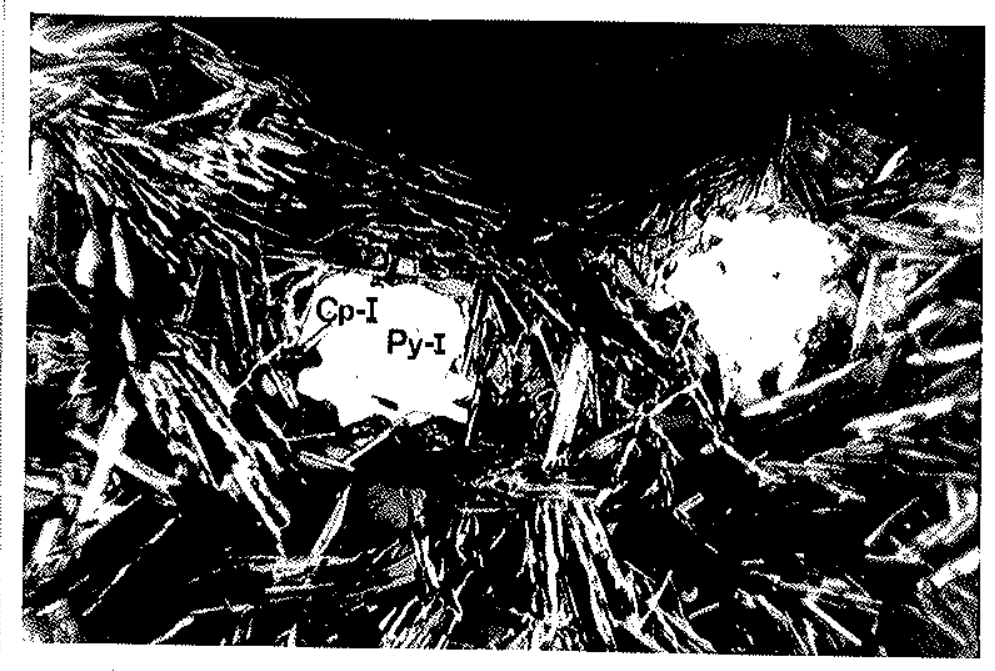

Fotomicrografia 20 - Textura fluidal

formada por lamelas orientadas de hematita ; que envolvem sulfetos depositados numa fase anterior. Notar a substituição de pirita. Nícois des cruzados: Aumento 847 vezes.

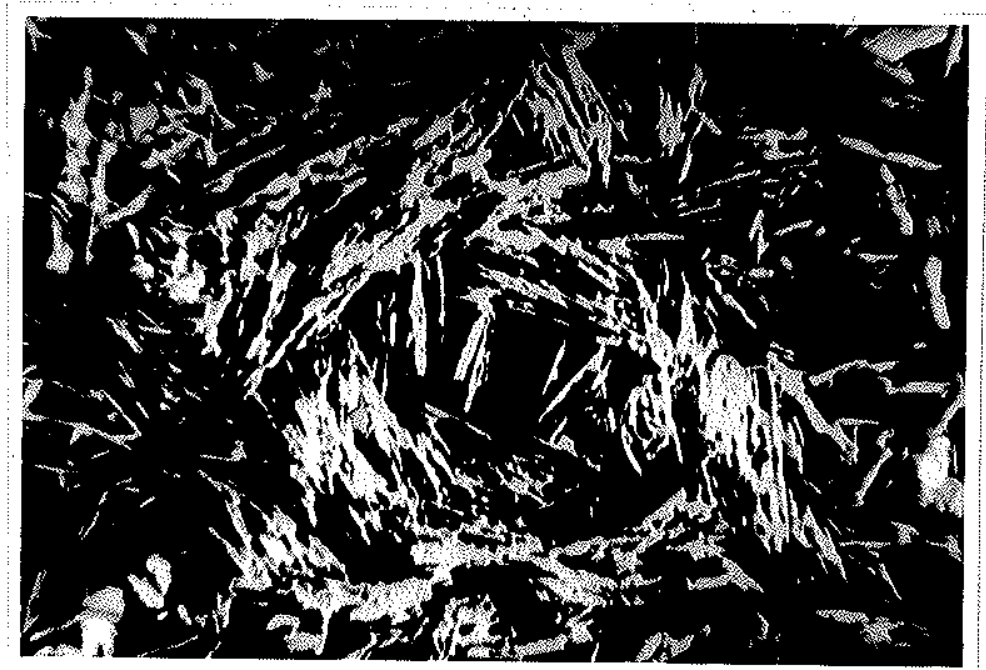

Fotomicrografia 21 - Arranjo concêntri co de lamelas de hematita especular, de vido movimentação durante a sua deposi ção. Nícois descruzados. Aumento 896 ve zes. 


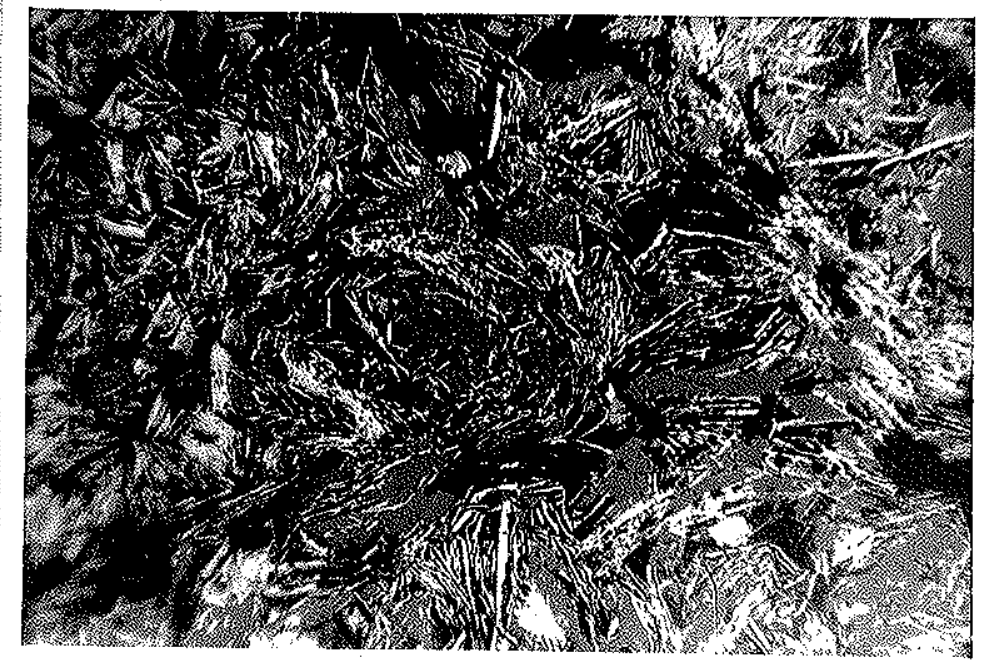

Fotomicrografia 22 - Cristais de he matita preenchendo espaços e englobando e substituindo fragmentos de rochas encaixantes. Nícois descruza dos. Aumento 700 vezes.

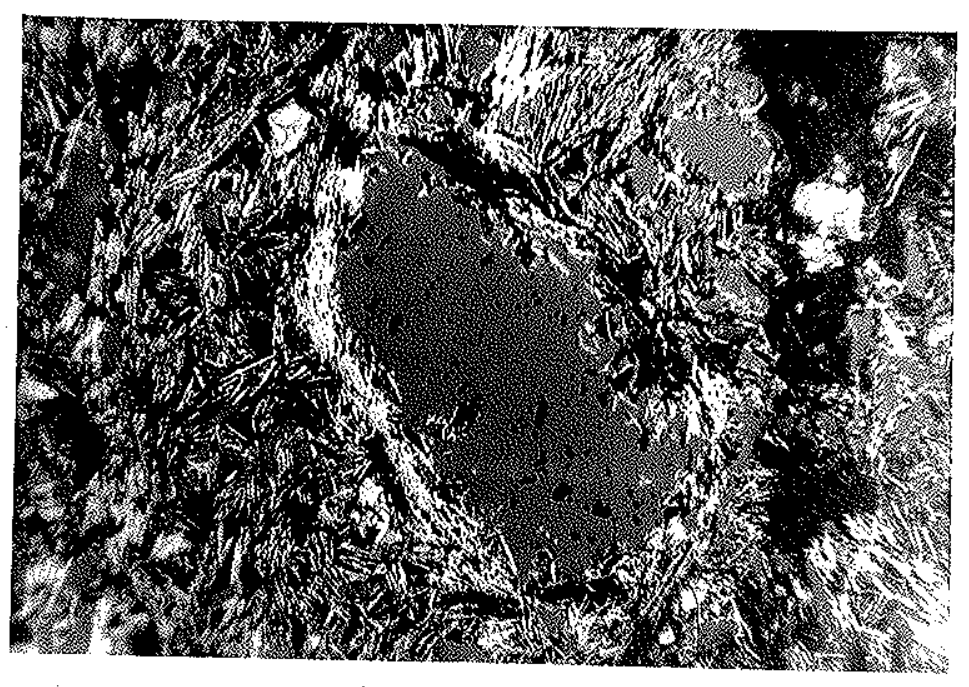

Fotomicrografia 23 - Fragmento de rocha encaixante, ao centro, sendo substituido por hematita especular ao longo das bordas. Nícois descruzados. Aumento 700 vezes. 


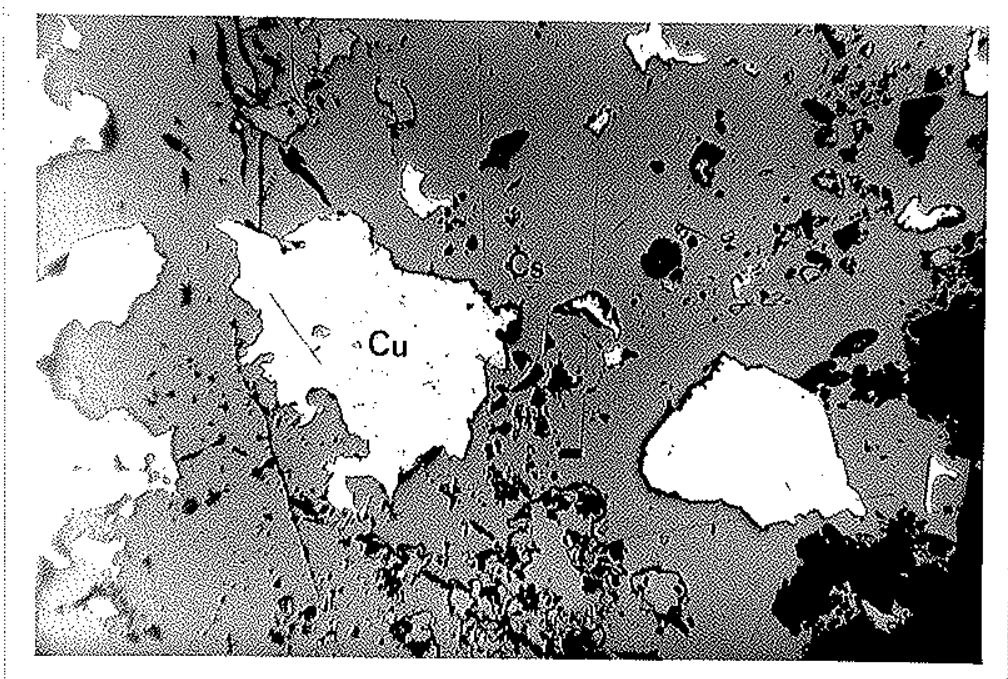

Fotomicrografia 24 - Massas irregulares de cobre nativo dispersas em calcosina. os corpos negros irregulares dispersos em calcosita são de cuprita. Aumento: 427 vezes.

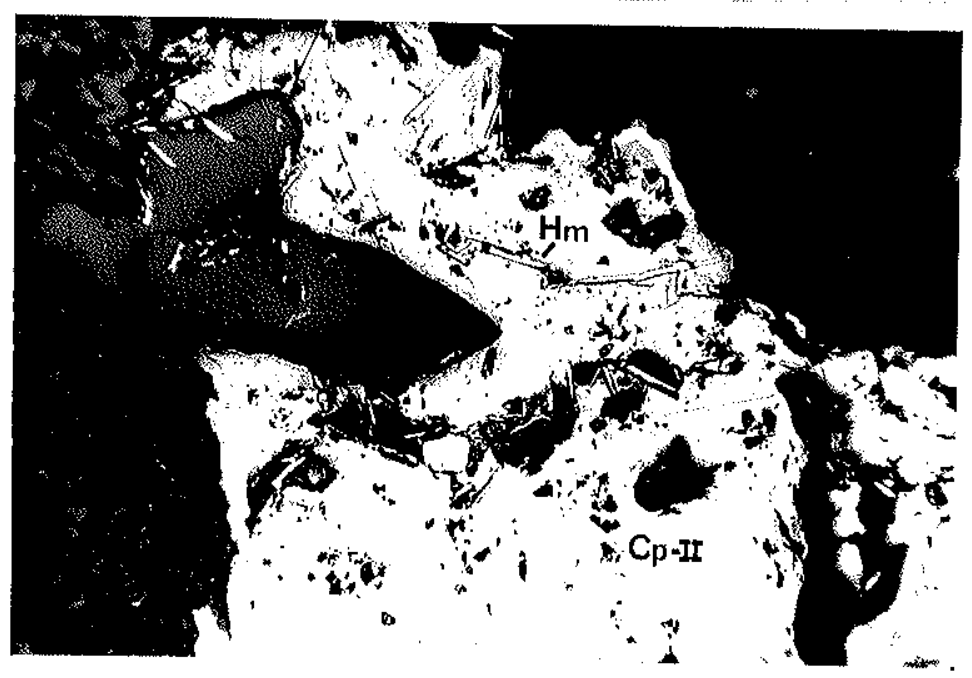

Fotomicrografia 25 - Mina Uruguai -Cris tais tabulares de hematica especular e ganga quartzosa associada sendo substituidos por calcopirita li da segunda ge ração. Aumento: 427 vezes. 


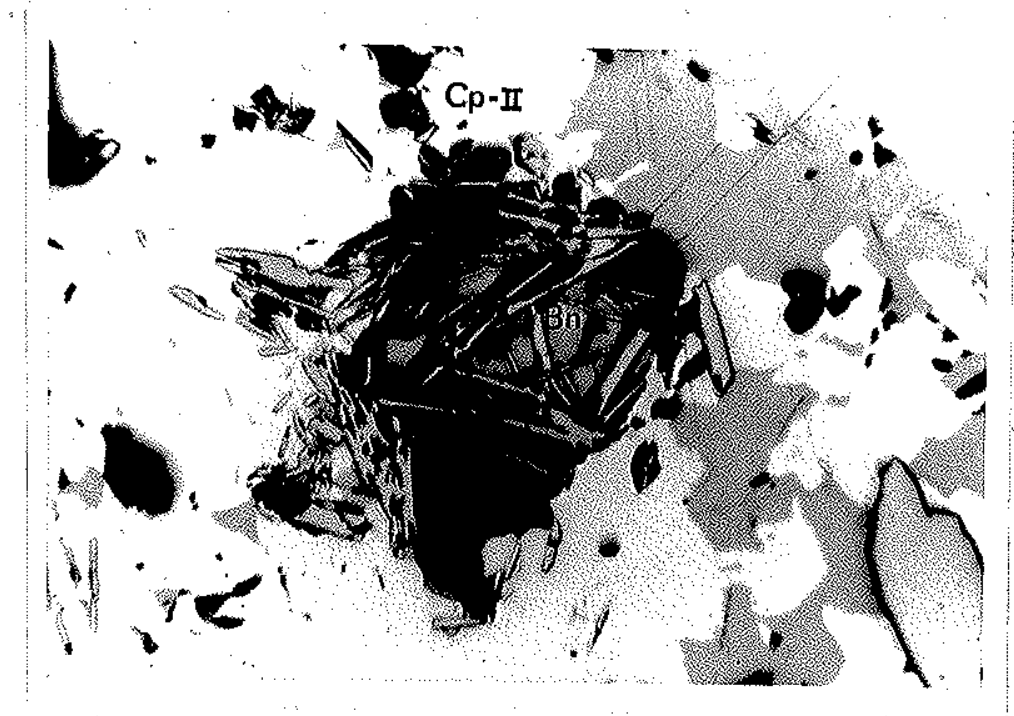

Fotomicrografia 26 - Calcopirita II, substituindo e englobando fragmento de minério, constituído por hematita I e bornita de fase anterior de mineralização. Nícois cruzados. Aumento 427 vezes.



Fotomicrografia 27 - Calcopirita II substituindo hematita e bornita an teriores. Nícois descruzados. Au mento de 427 vezes. 


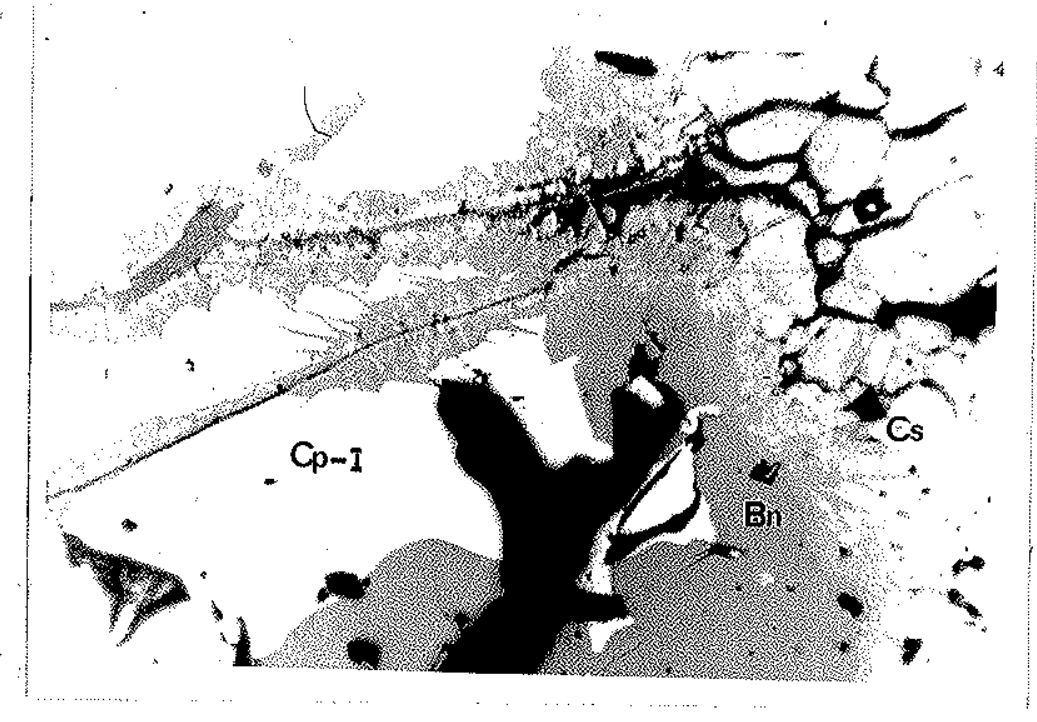

Potomicrografia 28 - Calcosita sen do substituida por bornita, preferencialmente ao longo de fraturas. A calcopirita por sua vez é substi tuída por bornita. Aumento 875 vezes.

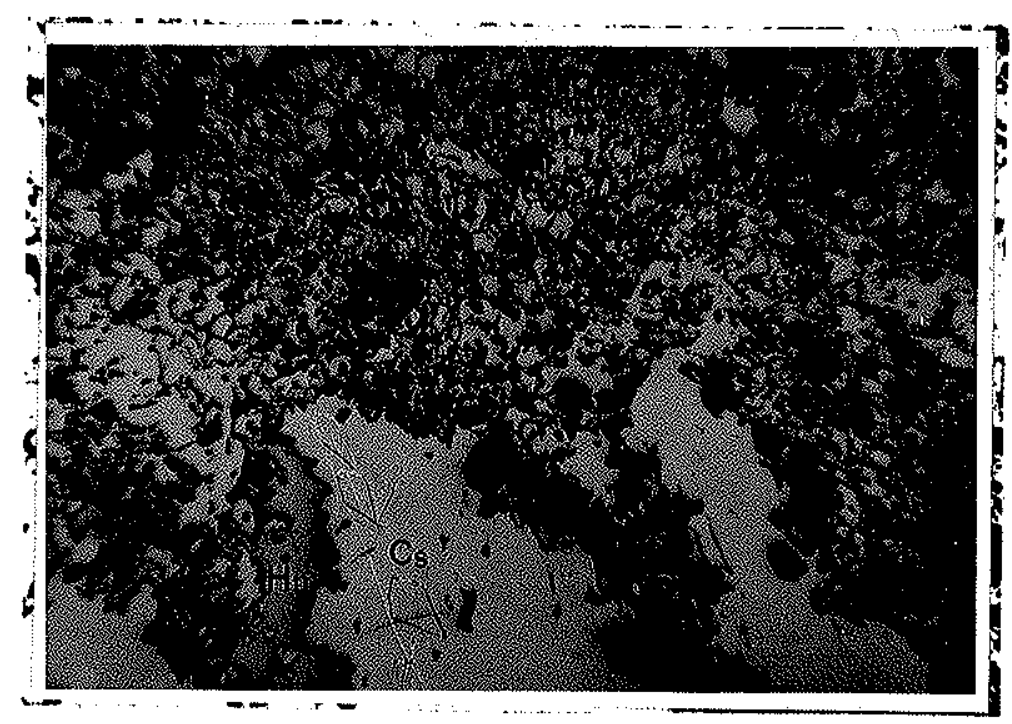

Fotomicrografia 29 - Mina Uruguai. Intercrescimento mirmequítico com plexo formado por calcosita, hema tita e cuprita (manchas negras). Nícois descruzados. Aumento 644 ve zes. 


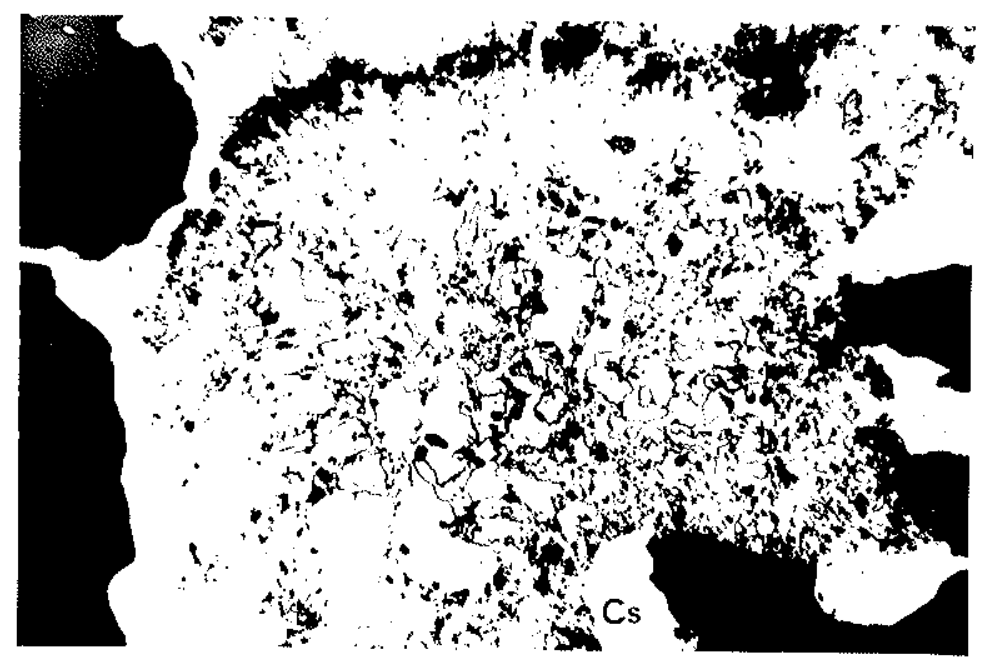

Fotomicrografia 30 - Intercrescimento mirmequítico complexo consistindo de remanescentes de calcosita, bornita e hematita. Nícois descruzados. Aumento de 427 vezes.

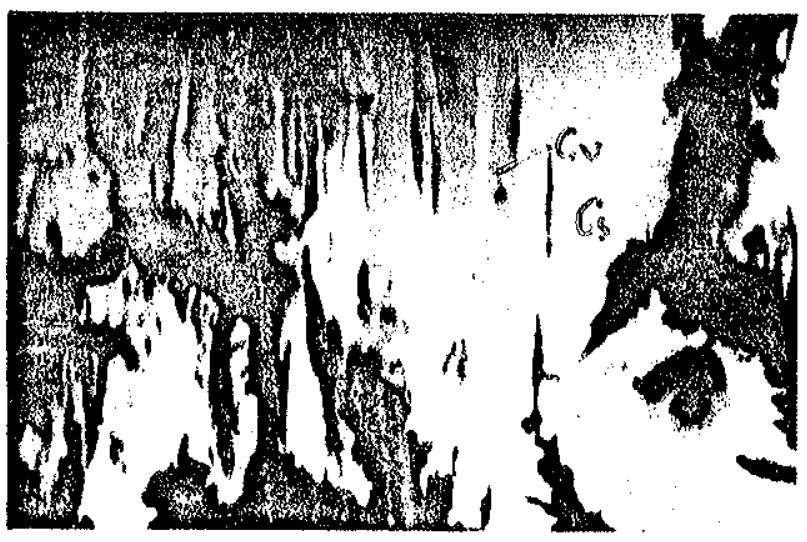

Fotomicrografia 31 - Zona intermediária. Lamelas de covelita substituindo calcosita segundo planos paralelos. Em negro, quartzoralaquita em cinzento. Seção po 1ida. Nicois descruzados. Aumento de 196 vezes. 


\section{XIII - PARAGENESE}

A sequência paragenética mineral de Camaquã foi elaborada em fun ção dos dados obtidos em 50 secções polidas e dezenas de secções delgadas. As associações minerais e as relações de campo observa das permitem inferir a existência de pelo menos 4 fases de minera lização, assinalando-se, contudo, que durante a deposição, movimen tos recorrentes se processavam ao longo das zonas principais de rup tura. Esses eventos tectônicos foram os prováveis responsáveis pelas mudanças de composição das soluções mineralizantes.

Inicialmente, as soluçōes devem ter sido ricas em sílica, ferro e enxôfre, com intensa deposição dos minerais de um determinado período, diminuindo rapidamente de intensidade no final da fase inicial. Após esta fase, culminada por um período de fraturamento, as soluções, embora ainda com os componentes anteriores, se enriqueceram em cobre, resultando na deposição de calcopirita e bornita subordinada. Novas ativações tectônicas se sucederam, com a reabertura das fratu ras mineralizadas.

Quase ao final da sequência de deposição, as soluções devem ter sofri do grandes alterações, ferro e magnésio atingindo concentrações sufi cientes para a deposição de hematita especular e clorita, além de quart zo em quantidades subordinadas. Encerrando a mineralização, ainda como resultado de pulsaçôes periódicas, deu-se nova deposição de piri ta e calcopirita em pequena concentraçāo; acompanhadas dos minerais de ganga, quartzo, calcita e barita.

E provável que a sequência de deposição tenha tido caráter quase con tínuo, embora alternada com eventos tectônicos. O esquema simplificado, é representado pela Tabela 11 , propondo-se as seguintes fases de mine ralização. 


\section{Fase Principal da Pirita}

Fase marcada inicialmente por alteração hidrotermal das paredes, com formação de caolim e sericita, seguida por deposição de quartzo I e pirita I, o primeiro sulfeto a se depositar. Estas soluçōes tiveram também ação sobre as paredes e fragmentos das rochas encaixantes, brechados e dispersos ao longo dos palnos de fraturamento, ocorrendo também, substituição e deposição de quartzo I e pirita I. Em certos casos, a linha de demarcação entre veios e parede é bem definida, po dendo haver, entretanto, transiçāo gradual. A presença generalizada de pirita disseminada, em quantidades ponderáveis nas rochas encai xantes, mesmo a muitos metros dos veios, deve ser atribuida à ação de enxofre sobre o conteúdo de ferro das próprias rochas encaixantes. As relações texturais observadas demonstram que a pirita, após e durante sua deposição, foi submetida a esforços, conforme revela o fraturamento dos cristais em quase todas as amostras, o que deixa claro que o movimento nas fraturas estava ativo.

\section{Fase Principal da Calcopirita}

Após o primeiro período de fraturamento, sobreveio a deposição de calcopirita I que, juntamente com pirita I, constitue a maior parte do minério primário da Mina. As evidências texturais e a presença de bornita granular disseminada, particularmente nos níveis profundos (400 metros de profundidade), sugerem que neste estádio, houve tam bém, a deposição de pequena quantidade de bornita hipógena. As ob servações ao microscópio demonstram que a bornita é posterior à calcopirita, entretanto, há possibilidades de contemporaneidade. A ganga acompanhante destes sulfetos é quartzo II de uma nova gera ção. A presença de fraturamento, não tão intenso quanto aquele que atingiu a pirita, é observável nos sulfetos, demonstrando um novo período de movimentação. 


\section{Fase da Hematita}

Após as duas primeira fases de deposição, houve um intervalo de tempo marcado por movimentações locais, ao longo das fraturas preexistentes, com consequente fraturamento dos minerais já deposi tados e reaberturas das fraturas mineralizadas nos estádios I e II. Houve também nova fase mineralizante caracterizada por uma minera logia diferente, particularmente bem desenvolvida na Zona Piritas da Mina Uruguai. Formou-se clorita nas paredes dos veios e filetes e também nas zonas extremamente brechadas da Zona Piritas, seguida por deposição de hematita especular, esta acompanhada por ganga quartzosa. A deposição de hematita se deu por preenchimento de fís suras e por fenômenos de substituição, não só dos sulfetos e gangas anteriores, como também das rochas encaixantes e fragmentos exis tentes nos locais de deposição.

\section{Fase Final}

Os éstudos efetuados demonstram que o estado final ainda é caracteri zado por uma recorrência de mineralização, em que as soluções mine ralizantes voltam inicialmente, a ter as características das fases 1 e 2 , produzindo zonamento em veios e porçōes da Mina Uruguai, particular mente na Zona Piritas. Este estádio parece ter iniciado com a deposição de pequena quantidade de pirita, seguida por calcopirita, que substitue pirita e bornita. A deposição da calcopirita é acompanhada por minerais de ganga, notadamente quartzo, calcita e barita , esta última encerrando a fase. Quartzo e calcita muitas vezes ocorrem juntos, em filetes mili métricos, nas porçōes centrais dos veios hematíticos. 
TABEIAA II

PARAGÊNESE MINERAL NA MINA DE CAMAQUÃ

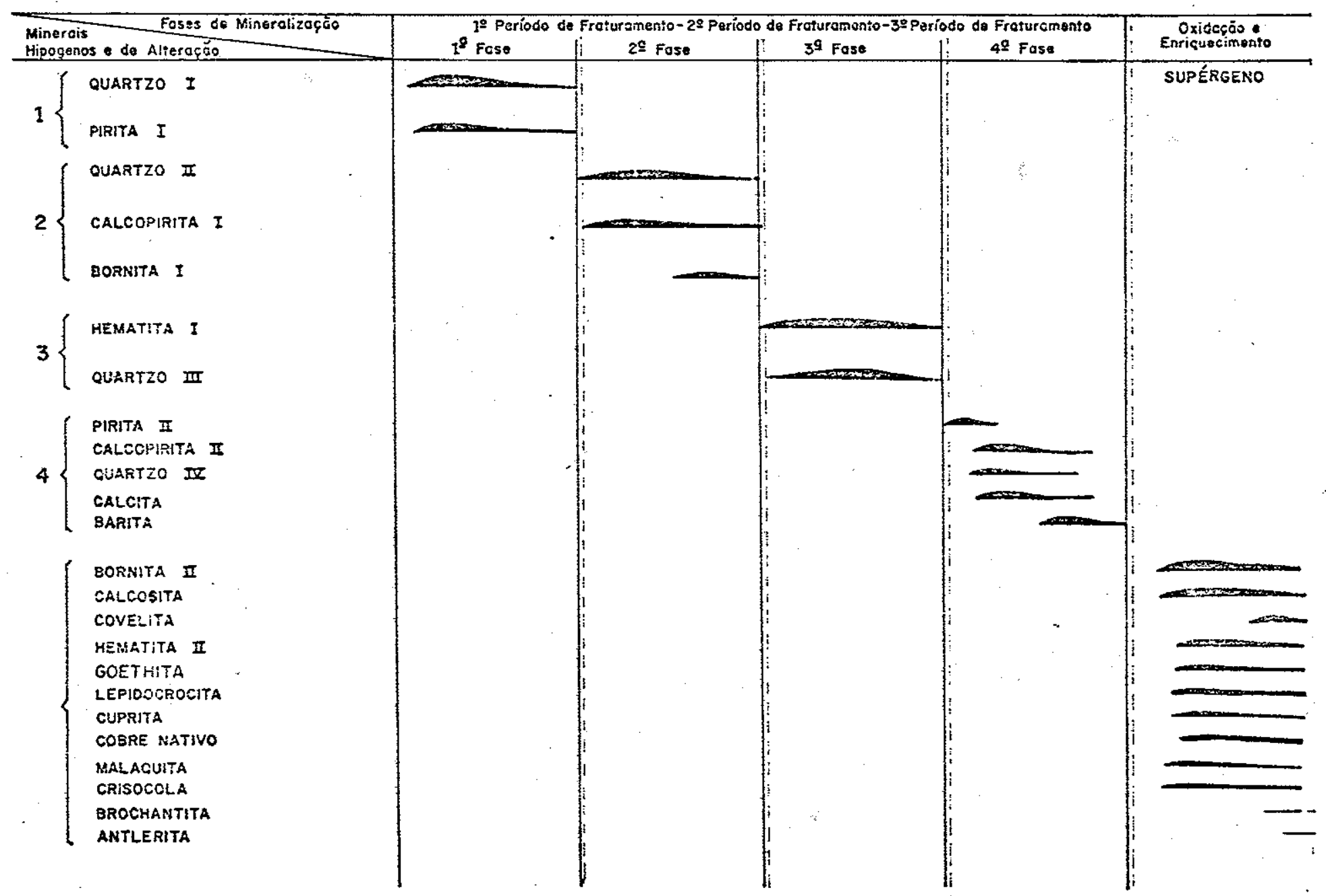


XIV - ALTERAÇÃO HIDR OTERMAL E ZONEAMENTO

Na Mina de Camaquã, as paredes de todas as rochas encaixantes dos filöes acham-se extemamente alteradas. Os veios e filetes possuem uma zona lateral de alteração que pode variar de alguns centímetros a vários metros. Entretanto, devido à pequena distância entre esses veios, as faixas de alteração individuais se superpõem definin do uma região continua alterada, cuja largura pode atingir 75 a 100 metros, nas Minas S. Luiz e Uruguai.

As relações de campo e os estudos efetuados ao microscópio, indicam que existiu um período de alteraçāo anterior à deposição dos sulfetos da primeira e segunda fase de mineralização, sendo caracterizado por intensa caolinização e sericitização das encaixantes. Os arenitos e conglomerados, que são as rochas encaixantes, possuem os grânulos de feldspato, rochas graníticas e rochas quartzo-feldspáticas, extre mamente sericitizados e caolinizados. Os minerais ferromagnesianos e os poucos fragmentós de vulcanitos existentes nessas rochas estão parcialmente cloritizados.

Silicificação intensa parece ter acompanhado, logo em seguida, esse período inicial, o que se depreende pela deposição de quartzo nas pare des dos veios e silicificação intensa, especialmente de brechas e are nitos. Estes se tornaram extremamente duros e adquiriram caráter quartzítico. Esta silicificação foi seguida e acompanhada por deposi ção de sulfetos da primeira e segunda fases de mineralização.

As soluções inicialmente ricas em $\mathrm{SiO}_{2}$, Fe e $\mathrm{S}$ tiveram a sua composi ção química modificada durante as fases da mineralização. A assembléia de minerais de alteração, formadas no primeiro período, houve superposição, especificamente na Mina Uruguai; Zona Piritas, de uma alteração clorítica, rica em Fe e $\mathrm{Mg}$, que foi subsequentemente acom panhada por mineralização de hematita especular. Este tipo de alteração, assume grande importancia no distrito, em razão dos problemas ligados à gênese da mineralização. 
A alteração clorítica tem sido objeto de estudos em vários distritos mineiros, citando-se os trabalhos de. Price, 1953; Das Gupta et al, 1965; Nilson, 1968; e, Meyer, 1967), que admitem que a cloritização intensa é indicativa de adição de grande quantidade de $\mathrm{Mg}$ e F'e à zona alterada.

Os efeitos desta alteração nas rochas encaixantes são marcantes. Conglomerados e arenitos adquirem uma coloração verde intensa: e no caso dos arenitos, junto às paredes dos veios, a matriz é, na quase totalidade, substituida por clorita, às vezes acompanhada por sericita.

Nas Minas S. Luiz e Uruguai foi observado zoneamento hipógeno, vertical e lateral. Na Mina S. Luiz, notou-se que a calcopirita e pirita aumentam em profundidade, sendo os sulfetos predominantes nos níveis 600 e 700

Na Mina Uruguai, há ainda mistura de sulfetos hipógenos e supérgenos, sendo difícil estimar as proporções relativas. Entretanto, ligeiro zo neamento lateral foi observado nas porções SW e W dos níveis 400 e 500. Especialmente na 7.ona Piritas, ocorre mineralização hernatítica, embora associada a pequena quantidade de calcopirita e pirita das fases de mineralização 1,2 e 4 (Tab, 11). 


\section{XV - OXIDAÇÃO E ENRIQUECIMENTO SUPÉRGENO}

As únicas descrições anteriores que fazem menção aos fenômenos de oxidação e enriquecimento supér geno na Mina de Camaquã, são de autoria de Leinz et al (1941, pág. 41 e 42). Estes autores descreve ram uma zona de oxidação com 5 a 8 metros de profundidade. Carac terizaram-na pelo aparecimento de ligeiras impregnações de mala quita e esporadicamente azurita, cuprita e cobre metálico.

Os mesmos autores também definiram uma zona de enriquecimento supérgeno que começa a cerca de 8 a 10 metros abaixo da superfície, contendo calcita, covelita, calcopirita e bornita. A sua extensão vai até pouco abaixo do nível 300 da Mina S. Luiz.

Foge ao objetivo deste trabalho o estudo em detalhe da estrutura e química da zona supérgena, pelo que limitamo-nos à descrição, em linhas gerais, dos principais aspectos relacionados à oxidação e enriquecimento supérgeno.

As observações ora efetuadas permitem deduzir que a profundidade de oxidação é extremamente variável, dependendo da topografia, estrutura e tipo de rocha. A oxidação é mais intensa e profunda nas zonas brecha das e falhadas existentes nos conglomerados. A topografia atual apre senta diferenças de cotas de até 100 metros ao longo do perfil longitudi nal dos veios, em relação ao nível topográfico mais baixo da Mina. Êste fato, associado às mudanças do nível freático local, contribue. : provavelmente, para acentuar as irregularidades de profundidade de oxidação.

A corroborar este fato; deve-se assinalar a presença, na Galeria dos Belgas, de cuprita associada a veios de calcosita maciça, o que caracte riza uma penetração de oxidação, na zona de enriquecimento supérgeno. 
A oxidação posterior à abertura da Mina é atualmente ativa até $\cdot o$ nível 600 da Mina S, Luiz e 500 da Mina Uruguai tendo sido facilitada pela circulação de água e ar ao longo de realces e planos de fratura mento das rochas.

A mineralogia observada na zona oxidada é representada pelos seguin tes minerais: malaquita, crisocola, covelita, cuprita, cobre nativo, hematita, óxidos de ferro hidratados, antlerita e brochantita. Limoni ta, particularmente goethita e lepidocrocita, juntamente com malaquita, são os minerais mais abundantes nessa zona, seguidos pelos outros minerais. Covelita aparece em pequena quantidade. Cuprita e cobre nativo foram observados ocorrendo como produtos da oxidaçāo da calco sita. A antlerita e brochantita formam películas sobre os sulfetos e revestem galerias e realces. A presença destes minerais deve ser atribuida à fase pós-abertura da mina, não excluindo, também, a possibilidade de formação anterior.

As investigaçōes ora efetuadas em todos os níveis das minas Uruguai e S. Luiz, demonstram que nesta última as quantidades relativas de calcosita e bornita decrescem em profundidade até aos níveis $500 \mathrm{e}$ 600 , atingindo uma porcentagem infima do nível 600. Observações mais detalhadas nos níveis 300 e 200 são dificultadas pelas lavras an tigas. No nível 100 o enriquecimento é típico, predominando calcosita e bornita. A zona de minério misturado se estende desde o nível 100 até ao nível 500 .

Na Mina Uruguai, os mapeamentos geológicos de detalhe efetuados en tre os níveis 100 e 500 demonstraram a inexistência de concentraçōes importantes de calcosita, correlacionáveis ao enriquecimento supérge no. Ao contrário da Mina S. Luiz, há uma predominância de bornita maciça e disseminada em todos os níveis. Particularmente no nível. 500 da Mina Uruguai, vários filōes são, na maior parte, constituıdos por bornita maciça. Bornita e calcosita, disseminadas foram, também, descritas em furos de sondagem entre 350 a 400 metros de profundidade. 
A caracterização segura do limite da zona de enriquecimento supér ge no é condicionada, portanto, pela dificuldade em discriminar quanto a natureza hipógena das calcositas e bornitas observadas em profundi dade.

A mineralogia dạ zona de enriquecimento supér geno observada nas minas Uruguai e S. Luiz é constituida predominantemente por: calcosita, covelita, bornita e hematita. Minerais hipógenos, ocorrendo em pequena porcentagem são representados por calcopirita, bornita, pirita e hematita. A calcosita se associa à calcopirita, pirita, bornita. A bornita substitue pirita e calcopirita. A hematita, apesar de resultar da substituição da calcopirita por bornita é, mais comumente, um pro duto de substituição de bornita por calcosita. 


\section{XVI. $1 \quad$ Generalidades}

Análises químicas para $\mathrm{S}, \mathrm{Fe}, \mathrm{Cu}, \mathrm{Co}, \mathrm{Ni}, \mathrm{Ag}, \mathrm{Pb}, \mathrm{Cr}, \mathrm{Zn}$ e As, foram efetuadas em minerais de minério da Mina de Camaquã, no meadamente pirita, calcopirita e hematita. Foram também efetuadas dosagens desses elementos em concentrados de minério e rochas ígneas regionais, supostamente relacionadas à mineralização.

Excetuando S, Fe e Cu, todos os outros elementos foram determina dos em hematita, concentrados de minério e rochas ígneas. Essas determinações tiveram como objetivo principal o conhecimento das suas concentrações e distribuição, bem como a obtenção de informa ções de natureza genética, úteis para o conhecimento da mineraliza ção primária no distrito.

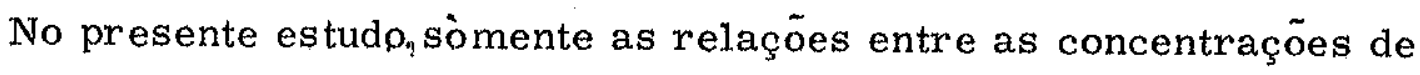
Co e $\mathrm{Ni}$ em sulfetos foram analisadas além da comparação entre os diversos elementos traço, contidos em concentrados e rochas ígneas regionais.

As relaçōes entre Co e Ni em hematitas, assim como conclusões gené ticas que por ventura pudessem ser obtidas a partir do estudo dos ele. mentos traço restantes, deixaram de ser apreciadas para serem abor dadas quando estiverem disponíveis resultados mais representativos.

Os gráficos de distribuição de Co e $\mathrm{Ni}$ foram elaborados segundo pro cedimento descrito por Cambell e Jarkovsky (1967). Nas análises efe tuadas por micro-sonda eletrônica o limite de deteção de Co e Ni é de 100 ppm. Entretanto, para comparação com os resultados obtidos por métodos espectrográficos e absorção atômica, arbitràriamente, foi admitido que os valores 100 ppm são equivalentes a 50 ppm.

Os resultados das análises por micro-sonda acham-se reunidos na Tabe la 12, enquanto os dados químicos obtidos por absorção atômica e espec trografia de raios $X$, estão enumerados nas Tabelas 1.3 a 1.7. 
XVI. 2

Distribuição dos Elementos Traço

A distribuição e concentração de elementos traço nos principais sulfe tos, em diversos tipos de depósitos, têm sido objeto de estudos de vários pesquisadores. Ultimamente, os resultados obtidos nessas investigaçōes vêm sendo utilizados para estimar temperaturas de for mação de minerais, identificar províncias metalogenéticas e, também. para discriminar ambientes de deposição mineral. Com respeito à concentração, distribuição e inferências genéticas, obtidas a partir de piritas e calcopiritas, várias publicaçōes importantes são assinala das, destacando-se os trabalhos de Gavelin e Gabrielson (1947), Fleischer (1955), Hawley e Nichol (1952, 1961), Loftus Hill et al (1967), Cambell e Jarkowsky (1967, 1968 e 1969).

No presente trabalho foram analisadas as relações entre Co e Ni, em piritas e calcopiritas, numa tentativa de obter dados significantes de importância para a gênese da mineralização primária. (Figs。: 24 e 25).

Esses resultados foram comparados com os dados obtidos por outros autores, para verificar sua aplicabilidade ao Distrito Cuprífero de Ca maquã. As determinações de elementos traço efetuadas em piritas e calcopiritas pertencentes às fases iniciais de mineralização, mostram que as conclusões obtidas com relação à distribuição e concentração dos elementos não diferem daquelas já esboçadas por Gavelin e Gabrielson (1947), Fleischer (1955) e Hawley e Nichol (1961).

Os conteúdos de Co e Ni nas piritas e calcopiritas foram caracteriza dos estatísticamente. Foram determinados: média aritmética, disper são, desvio padrão e coeficiente de variação, cujos resultados estão contidos na Tabela 17. 


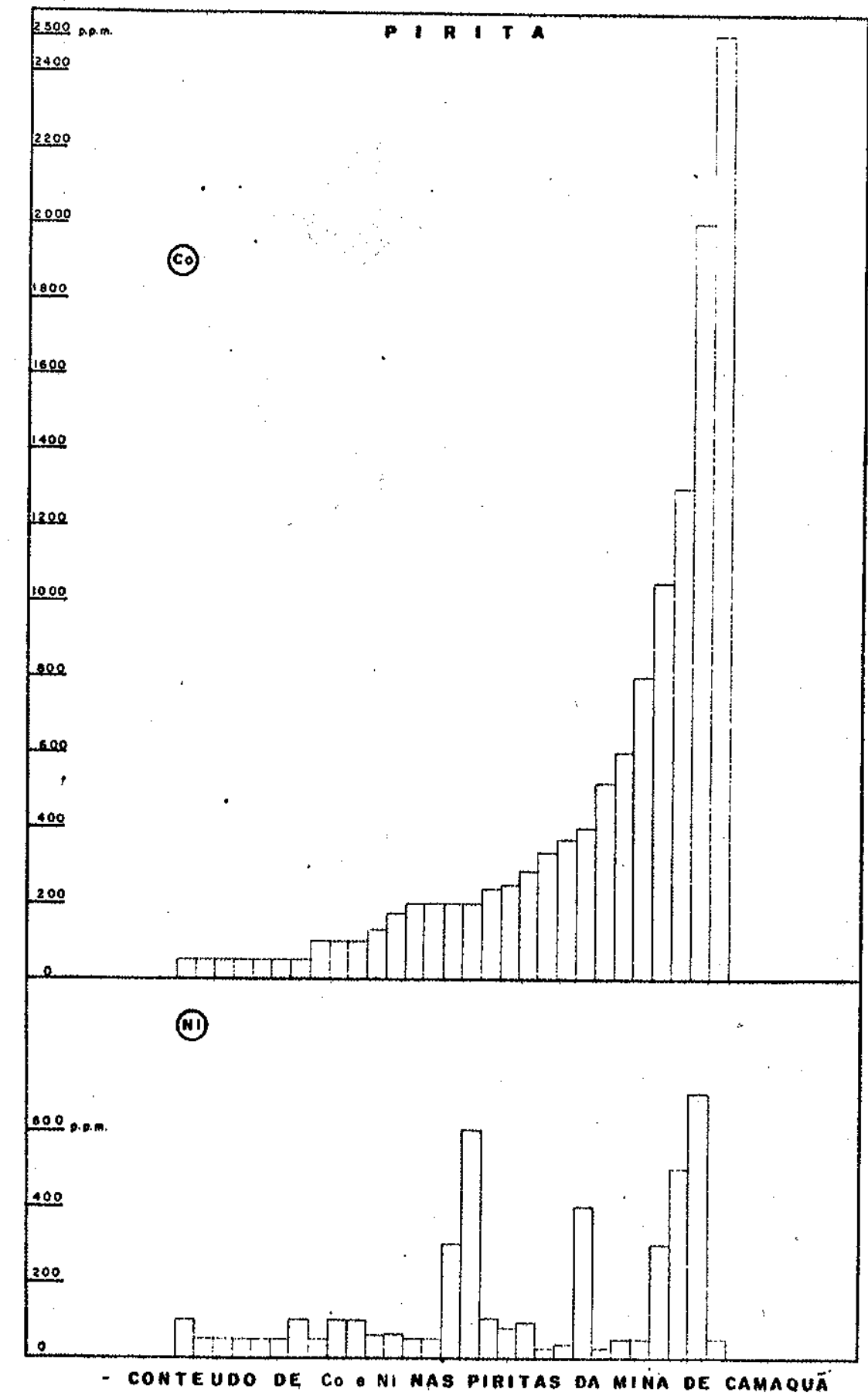

fig. 24 


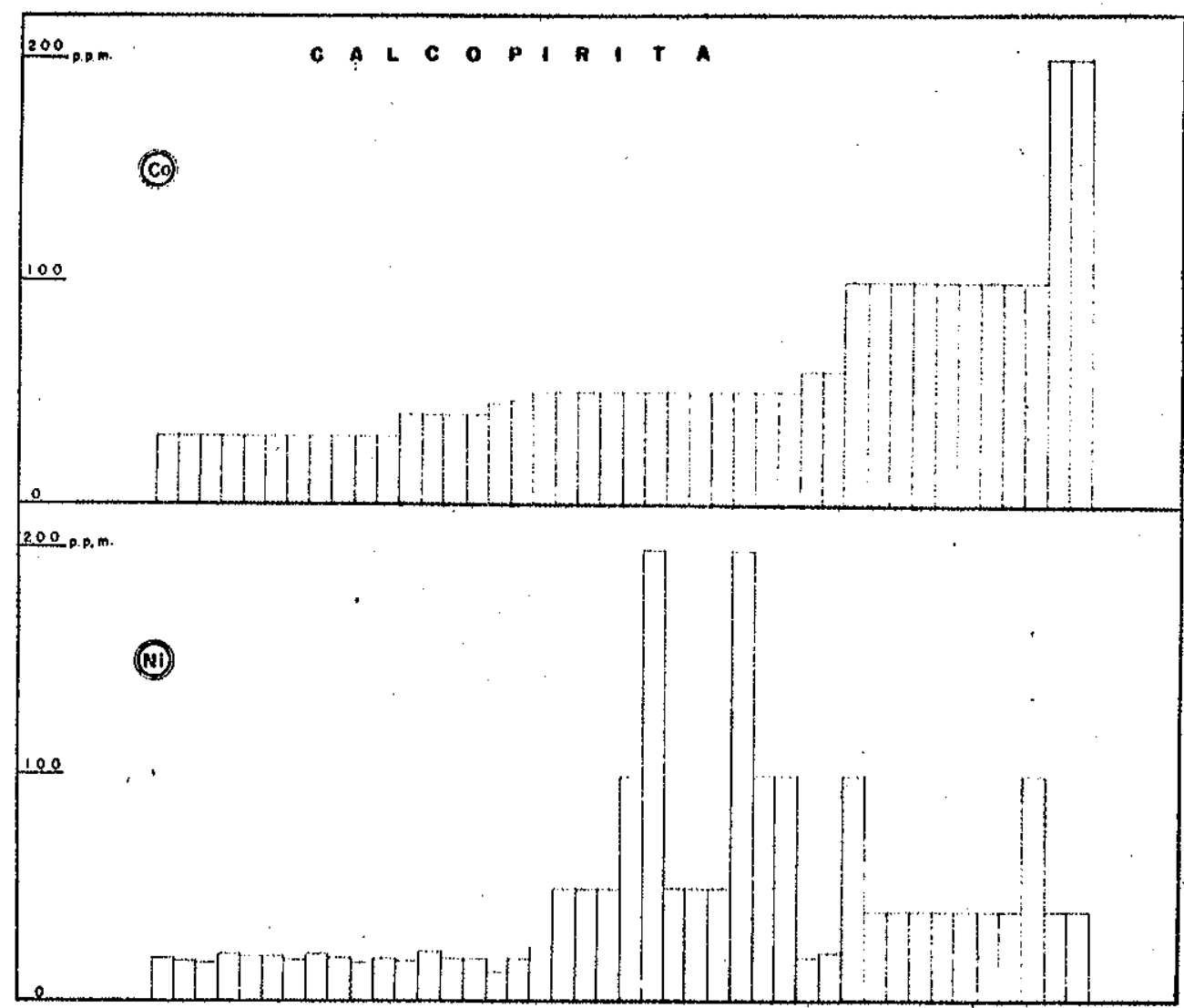

CONTEUDO DE Co NH DAS CALCOPIAITAS DA MINA Do CAMAQUÁ

Fig. 25 
TABELA 12

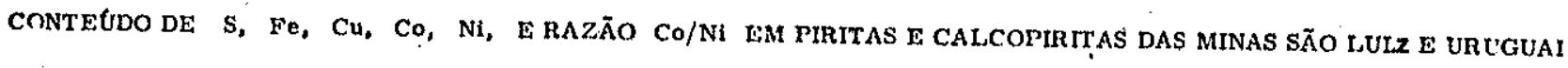

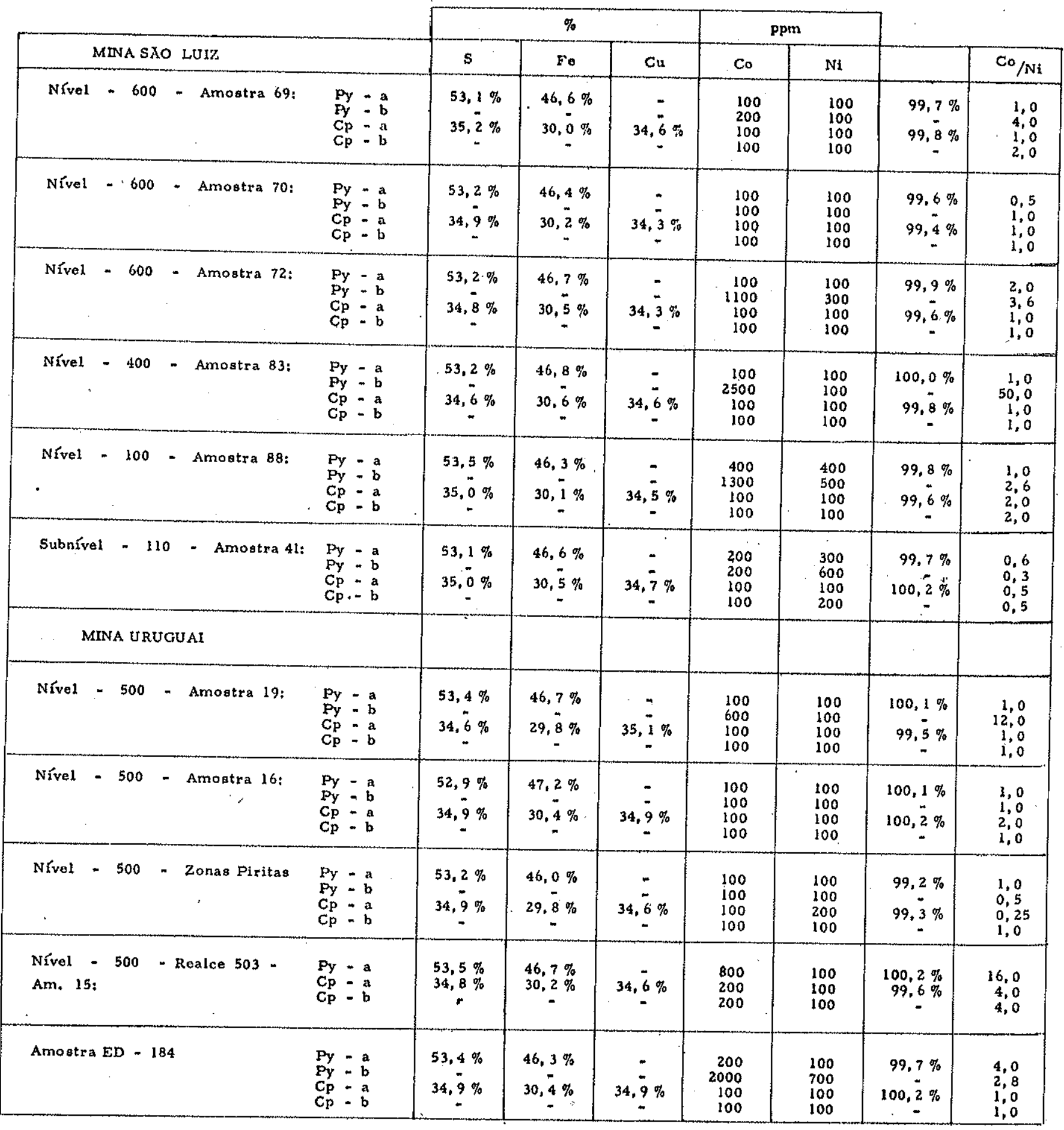

OBS:- Anállses efetuadas com micro-Bonda cletrônica
$\left.\begin{array}{l}\text { Py }-a \\ \text { Py }- \text { b }\end{array}\right\}$ Pirita - Crietais individualizados de uma mesma amostra
$\begin{aligned} & C_{p}-a \\ & C p\end{aligned}-$ Calcopirita $-I d e m$ 


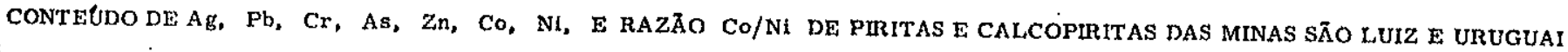

\begin{tabular}{|c|c|c|c|c|c|c|c|c|c|c|}
\hline \multirow{2}{*}{\multicolumn{2}{|c|}{ MINA SAO LUIZ }} & & \multicolumn{7}{|c|}{ ppm: } & \multirow{2}{*}{$\mathrm{Co} / \mathrm{Ni}$} \\
\hline & & & $\mathrm{Ag}$ & $\mathrm{Pb}$ & $\mathrm{Cr}$ & As & $\mathrm{Zn}$ & Co & $\mathrm{Ni}$ & \\
\hline \multicolumn{11}{|c|}{ PIRITA } \\
\hline \multirow{3}{*}{$\begin{array}{l}\text { Nivel } 500 \text { pés } \\
\text { Nível } 400 " ~\end{array}$} & Amostra 74 & Py & 10 & 15 & 15 & 70 & 25 & 175 & 63 & 2,7 \\
\hline & Amostra 81 & $\mathrm{Py}_{\mathrm{a}}$ & 20 & 25 & 30 & 130 & 50 & 240 & 106 & 2,2 \\
\hline & & $\mathrm{Py}_{\mathrm{b}}$ & 20 & 10 & 30 & 140 & 40 & 285 & 95 & 3,0 \\
\hline \multicolumn{2}{|c|}{ Sub-nível 310 pés Amostra 25} & Py & $<10$ & 10 & 30 & 80 & 40 & 250 & 80 & 3,1 \\
\hline \multirow{2}{*}{\multicolumn{2}{|c|}{ Ed -180}} & $\mathrm{Py}_{\mathrm{a}}$ & 55 & 25 & 30 & 45 & 30 & 370 & 38 & 9,0 \\
\hline & & $P_{y_{b}}$ & 30 & 10 & 30 & 45 & 15 & 520 & 25 & 20,0 \\
\hline \multicolumn{2}{|l|}{$\begin{array}{l}\text { Ed }-178 \\
\text { São Luiz }\end{array}$} & Py & 20 & 20 & 20 & 30 & 30 & 335 & 23 & 14,0 \\
\hline \multicolumn{2}{|l|}{ São Luiz } & Py & 15 & 25 & 20 & 60 & 20 & 130 & 60 & 2,1 \\
\hline \multicolumn{11}{|c|}{ CALCOPIRITA } \\
\hline Nível 600 & Amostra 69 & $\mathrm{Cp}$ & 50 & 35 & 35 & 3 & 35 & 35 & 19 & 1,8 \\
\hline Nível 600 & Amostra 70 & $C_{p}$ & 10 & 10 & 35 & 5 & 100 & 40 & 22 & 1,8 \\
\hline Nivel 600 & & $\mathrm{Cp}$ & 20 & 10 & 35 & 10 & 20 & 35 & 18 & 1,9 \\
\hline Nivel 400 & Amostra 83 & $c p$ & 25 & 25 & 35 & 4 & 30 & 60 & 20 & 3,0 \\
\hline Nível 400 & Amostra $84_{A}$ & $C_{p}$ & 40 & 20 & 35 & 3 & 15 & 35 & 17 & 2,0 \\
\hline Nível 300 & Amostra 86 & $\mathrm{Cp}$ & 15 & 15 & 35 & 7 & 20 & 45 & 13 & 3,4 \\
\hline Nível 100 & Belgas & $\mathrm{Cp}$ & 40 & 25 & 40 & 4 & 25 & 40 & 19 & 2,1 \\
\hline$E d-180$ & & $\mathrm{Cp}$. & 30 & 20 & 35 & 8 & 15 & 50 & 24 & 2,0 \\
\hline \multicolumn{2}{|l|}{ Filäo São Júlio } & $C p$ & 40 & 25 & 40 & 4 & 25 & 40 & 19 & 2,1 \\
\hline \multicolumn{11}{|c|}{ 'MINA URUGUAI } \\
\hline \multicolumn{11}{|c|}{ CALCOPIRITÁ } \\
\hline Nível 500 & Amostra 17 & $\mathrm{Cp}$ & 15 & 15 & 35 & 7 & 25 & 35 & 21 & 1,6 \\
\hline Nível 500 & Amostra 198 & $\mathrm{Cp}$ & 50 & 20 & 35 & 9 & 35 & 35 & 20 & 1,7 \\
\hline Nível 400 & Amostra 216 & $\mathrm{Cp}_{\mathrm{p}}$ & 30 & 40 & 35 & 2 & 10 & 35 & 20 & 1,7 \\
\hline Nível 400 & Ed -179 & $C_{p}$ & 20 & 25 & 35 & 2 & 10 & 35 & 18. & 1,9 \\
\hline Nível 300 & Amostra 25 & $\mathrm{Cp}$ & 30 & 15 & 35 & 7 & 40 & 35 & 21 & 1,6 \\
\hline Nível 300 & Amostra 24 & $\mathrm{Cp}$ & 35 & 20 & 35 & 4 & 35 & 35 & 19 & 1,8 \\
\hline $\mathrm{Cp}_{\mathrm{p}}-1$ & & $\mathrm{Cp}$ & 20 & 25 & 35 & 2 & $<10$ & 40 & 18 & 2,2 \\
\hline $\mathrm{Cp}-2$ & & $\mathrm{Cp}$ & 40 & 20 & 35 & 3 & 15 & 35 & 17 & 2,0 \\
\hline$C p-4$ & & $C_{P}$ & 40 & 25 & 40 & 4 & 25 & 47 & 19 & 2,4 \\
\hline$C p-5$ & & $\mathrm{Cp}$ & 30 & 35 & 35 & 4 & 25 & 60 & 22 & 2,7 \\
\hline$C_{p} \cdot 6$ & & $C p$ & 35 & 20 & 35 & 4 & 35 & 35 & 19 & 1,8 \\
\hline
\end{tabular}

OBS: - As análise日 de $\mathrm{Ag}, \mathrm{Pb}, \mathrm{Cr}, \mathrm{Zn}$ e $\mathrm{Ni}$ foram efetuadas por fluorescência de raios $\mathrm{X}$.

* A.s determinações de Co foram realizadas por espectrofotometria de aboorção atômica.

$\left.\begin{array}{l}=\mathrm{Py}_{\mathrm{a}} \\ -\mathrm{Py}_{\mathrm{b}}\end{array}\right\}$ Pirita - Criatais individualizadoa de uma mesma amostra 
TABELA 14

Concentração de

$\mathrm{Ag}, \mathrm{Pb}, \mathrm{Cr}, \mathrm{As}, \mathrm{Zn}, \mathrm{Co}$ e $\mathrm{Ni}$

em hematita da Mina Uruguai

\begin{tabular}{|c|c|c|c|c|c|c|c|}
\hline \multirow{2}{*}{$\begin{array}{c}\text { Mina } \\
\text { Uruguai }\end{array}$} & \multicolumn{7}{|c|}{$\mathrm{ppm}$} \\
\hline & $\mathrm{Ag}$ & $\mathrm{Pb}$ & $\mathrm{Cr}$ & As & $\mathrm{Zn}$ & Co & $\mathrm{Ni}$ \\
\hline Hematita 1 & 20 & 10 & 50 & 3 & 65 & 95 & 13 \\
\hline Hematita 2 & 25 & 20 & 30 & - & 40 & 75 & 8 \\
\hline Hematita 3 & $m$ & - & - & - & - & - & - \\
\hline Hematita 4 & 15 & - & 20 & 3 & 40 & 95 & 15 \\
\hline Hematita 5 & 30 & 8 & 50 & 4 & 20 & 75 & 11 \\
\hline
\end{tabular}

TABELA 15

Conteúdo de

$\mathrm{Pb} ; \mathrm{Zn}, \mathrm{Cu}, \mathrm{Ni}, \mathrm{Co}$ e $\mathrm{Cr}$ em

Andesitos e Granitos da Região

Caçapava - Lavras

\begin{tabular}{|c|c|c|c|c|c|c|c|}
\hline \multirow{2}{*}{ Amostra } & \multirow{2}{*}{ Rocha } & \multicolumn{6}{|c|}{$\mathrm{ppm}$} \\
\hline & & $\overline{\mathrm{Pb}}$ & $\overline{Z n}$ & $\mathrm{Cu}$ & $\mathrm{Ni}$ & $\mathrm{Co}$ & $\mathrm{Cr}$ \\
\hline$A m-160$ & Andesito Rodeio Velho & 25 & 145 & 100 & 65 & 35 & 35 \\
\hline Am- 161 & Andesito Rodeio Velho & 35 & 165 & 50 & 60 & 45 & 35 \\
\hline Seival- 1 & Andesito Hilário & 25 & 165 & 75 & 30 & 40 & 50 \\
\hline Seival- 2 & Andesito Hilário & 30 & 125 & 25 & 30 & 25 & 30 \\
\hline $\mathrm{GA}-3-\mathrm{RS}$ & Granito Caçapava & 45 & 25 & 35 & 75 & 5 & 70 \\
\hline GA-3-RS & Granito Caçapava & 40 & 40 & 40 & 65 & 5 & 70 \\
\hline
\end{tabular}


TABELA 16

Conteúdos de

$\mathrm{Ag}, \mathrm{Pb}, \mathrm{Cr}, \mathrm{As}, \mathrm{Zn}, \mathrm{Co}, \mathrm{Ni}$ e $\mathrm{Cu}$ em

Concentrados da Mina de Camaquã

\begin{tabular}{|c|c|c|c|c|c|c|c|c|c|c|c|}
\hline \multirow{2}{*}{ Ano } & \multirow{2}{*}{ Trimestre } & \multirow{2}{*}{$\begin{array}{c}\text { Tonelagem de } \\
\text { Concentrado } \\
(t)\end{array}$} & \multirow{2}{*}{ Amostra } & \multicolumn{7}{|c|}{ ppm } & \multirow{2}{*}{$\begin{array}{l}\% \\
\mathrm{Cu}\end{array}$} \\
\hline & & & & $\mathrm{Ag}$ & $\mathrm{Pb}$ & $\mathrm{Cr}$ & As & $\mathrm{Zn}$ & Co & $\mathrm{Ni}$ & \\
\hline \multirow{5}{*}{1971} & 10 Trim. & 88.716 & Concentrado 1 & 170 & 30 & 30 & 30 & 65 & 80 & 30 & 32,9 \\
\hline & 20 Trim. & 114.004 & Concentrado 2 & 120 & 40 & 35 & 30 & 15 & 95 & 30 & 32,0 \\
\hline & 39 Trim. & 138.807 & Concentrado 3 & 130 & 40 & 35 & 30 & 10 & 85 & 30 & 33,67 \\
\hline & 49 Trim. & 138.555 & Concentrado 4 & 110 & 35 & 35 & 30 & 50 & 85 & 30 & 35,93 \\
\hline & & 480.000 & Concentrado 5 & 140 & 30 & 35 & 30 & 25 & 140 & 30 & 30,41 \\
\hline
\end{tabular}

OBS: As análises foram efetuadas em amostras médias compostas. O concentrado no 5 é a amostra representativa dos quatro trimestres. 
TABELA 17

ANÁLISE ESTATÍTICA

\begin{tabular}{|c|c|c|c|c|c|c|c|}
\hline Mineral & Elemento & $\begin{array}{l}\text { No de } \\
\text { Elementos }\end{array}$ & $\begin{array}{c}\text { Média } \\
\text { Aritmética } \\
\text { em ppm } \\
\text { (X) }\end{array}$ & $\begin{array}{l}\text { Dispersão } \\
\left(S^{2}\right)\end{array}$ & $\begin{array}{l}\text { Desvio } \\
\text { Padrão: } \\
\text { (S) }\end{array}$ & $\begin{array}{c}\text { Coeficiente } \\
\text { de } \\
\text { Variação } \\
(\text { Vx\%) }\end{array}$ & $\begin{array}{l}\text { Coeficiente } \\
\text { de } \\
\text { Correlação }\end{array}$ \\
\hline Pirita & $\begin{array}{l}\mathrm{Co} \\
\mathrm{Ni}\end{array}$ & $\begin{array}{l}27 \\
27\end{array}$ & $\begin{array}{l}457 \\
143\end{array}$ & $\begin{array}{r}356.567 \\
33.185\end{array}$ & $\begin{array}{l}597 \\
182\end{array}$ & $\begin{array}{l}130 \\
127\end{array}$ & $\begin{array}{l}0 \\
0,389\end{array}$ \\
\hline Calcopirita & $\begin{array}{l}\mathrm{Co} \\
\mathrm{Ni}\end{array}$ & $\begin{array}{l}38 \\
38\end{array}$ & $\begin{array}{l}65 \\
48\end{array}$ & $\begin{array}{l}1.633 \\
2.006\end{array}$ & $\begin{array}{l}40 \\
45\end{array}$ & $\begin{array}{l}62 \\
92\end{array}$ & 0,182 \\
\hline
\end{tabular}




\section{Pirita}

Cobalto - Nas piritas da Mina de Camaquá, o Co está preferencial mente concentrado, pela ordem, em pirita e calcopirita. Os teores estão entre 25 e 100 ppm e indicam não existir nenhuma variação sistemática em profundidade, observan do-se contudo, que as concentraçōes são extremamente irregulares, mesmo numa mesma amostra, veio ou nível. O valor médio é de $457 \mathrm{ppm}$.

Níquel - O conteúdo de $\mathrm{Ni}$ é de 200 a $13 \mathrm{ppm}$. A exemplo do Co, no ta-se que sua distribuição também é irregular, não havendo variação sistemática em profundidade. A média aritmética é 143 ppm.

Prata - Os teores de prata variam entre 55 e 10 ppm. O número de análises não é suficiente para deduzir o comportamento tridi mensional.

Cromio - As amostras possuem conteudos entre 30 e $15 \mathrm{ppm}$ de $\mathrm{Cr}$.

Chumbo - As concentrações de $\mathrm{Pb}$ são baixas, entre os limites de 25 e $10 \mathrm{ppm}$, sendo o valor médio de $17 \mathrm{ppm}$.

Zinco - Os valores de Zn oscilam entre 50 e 15, com média de 31 ppm.

Arsenio - Os conteudos de arsenio estãò entre 140 a 39 ppm, sendo o valor médio 75 ppm. 


\section{Calcopirita}

Cobalto - As concentraçōes de Co na calcopirita variam de 100 a 35 ppm, conteudo mais baixo do que nas piritas, sendo o valor médio $55 \mathrm{ppm}$. A exemplo da pirita, não se notou distribuição regular de Co em profundidade.

Níquel - Os valores de Ni são baixos e variam entre 200 e 13 ppm, sem variação sistemática tridimensional. A média aritmé tica é 48 ppm.

Prata - A Ag ocorre em porcentagem baixa, de 50 a $13 \mathrm{ppm}$, não apresentando variação sistemática. As concentraçōes de $\mathrm{Ag}$, tanto na pirita quanto na calcopirita, se mostram sensivelmente iguais.

Cromio - Os valores de $\mathrm{Cr}$ variam entre 50 e 30 ppm.

Chumbo - $\mathrm{O} \mathrm{Pb}$ apresenta baixa concentração, entre os limites de 40 e $10 \mathrm{ppm}$ com valor médio de $23 \mathrm{ppm}$, Notou-se um pequeno enriquecimento na calcopirita, em relação à pirita.

Zinco - O Zn ocorre em proporçäo de 100 e 10 ppm, sendo a média 28 ppm. Sua distribuição é irregular, não se notando diferen ças marcantes entre pirita e calcopirita.

Arsenio - O As é majs abundante na pirita do que calcopirita, mas os teores observados ainda são extremamente baixos, entre 10 e 3 ppm, com valor médio de 5 ppm. 
Em face dos resultados obtidos deduz-se que Co, Ni e As são elemen tos concentrados preferencialmente na pirita, seus valores médios mais elevados do que na calcopirita, coincidem com as observações efetuadas por Gavelin e Gabrielson (1947), Fleischer (1955), e Hawley e Nichol (1961). As concentrações de Co e Ni, especialmente em piri ta, são extremamente irregulares, conforme mostram os valores de dispersão, obtidos pela análise estatística.

Não há nenhuma distribuiçăo sistemática deșes 3 elementos em pro fundidade, nem correlação entre Co e Ni, conforme se depreende dos baixos coeficientes de correlação.

A irregularidade das concentrações de Co e $\mathrm{Ni}$ configura o caráter hi drotermal plutógeno das piritas da Mina de Camaquã, o que está de acordo com as observaçōes efetuadas por Cambell e Jarkowsky (1967, $1968,1969)$.

A partir de centenas de análises químicas para Co e $\mathrm{Ni}$, efetuadas em piritas e pirrotitas procedentes de ambientes metalogenéticos os mais diversos, esses autores demonstraram que piritas de origem hidroter mal plutógena, possuem conteudos de Co e Ni irregulares e elevados. Este comportamento caracteriza uma área metalogenética, mas tạ bem depósitos ou veios isolados.

Loftus Hill et al (1967), fizeram um levantamento dos resultados obti dos por vários investigadores, concernentes ao uso da razão Co: $\mathrm{Ni}$ na solução de problemas metalogenéticos, incorporando ainda conclu sões de pesquisa própiria. Concluiram que essa razão ê, potencialmente, um discriminador útil entre ambientes de deposição mineral sedimentar e magmático hidrotermal, possibilitando a classificação das piritas em vários grupos genéticos: 
a) formadas em ambientes sedimentares,

b) de origem vulcânica,

c) de origem vulcânica, associadas com minerais de $\mathrm{Pb}$ e $\mathrm{Zn}$,

d) associadas a intrusōes graníticas, ao lado de cassiterita e galenas ar gentíferas.

Excetuando 3 amostras, cujas determinações de Co e Ni foram efetua das com micro-sonda eletrônica, todas as piritas e calcopiritas ora. analisadas, demonstraram possuir razões $\mathrm{Co}: \mathrm{Ni} \geqslant 1$.

As amostras com razão igual à unidacle, normalmente correspondem a conteúdos de Co e Ni abaixo do limite de precisão da micro-sonda $(100 \mathrm{ppm})$ motivo pelo qual esses cocientes não têm significado real.

A partir dos resultados obtidos por todos os autores acima citados, e considerando válida a correlação com os depósitos de sulfetos por eles estudados, poder-se-ia inferir que as piritas primárias do Distrito

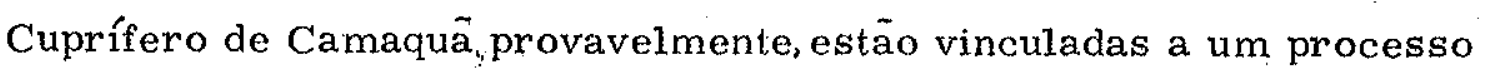
magmático regional. 
XVII - ORIGEM DA MINERALIZACÃO PRIMÁRIA

Vários investigadores já emitiram opiniões quanto à possível gênese das mineralizações de cobre no Polígono Cuprífero Riograndense, específicamente na região de Caçapava-Lavras. As interpretações, no entanto, são controvertidas entre si, conforme se verifica nas diversas sequências estratigráficas propostas (Tab. 3), não havendo, a té agora, observações conclusivas quanto à relação entre a minerali. zação e determinada fase magmática.

As opiniōes de Leinz e Barbosa (1941) e Leinz e Almeida (1941) podem. ser sumarizadas da seguinte maneira:

a) as soluções mineralizadoras provém da atividade magmática andesítica e as jazidas se formaram na fase final da consolida ção do mesmo magma;

b) a mineralização se efetuou através de zonas de fraqueza nas ro chas, resultantes das perturbações tectônicas motivadas pelo vulcanismo andesítico;

c) essa atividade é considerada posterior à deposição da sêrie Ca maquã.

Melcher e Mau (1959, pág. 49) apresentaram uma revisão da estratigra fia da região e, como decorrência, propuseram uma nova interpretaçäo genética da mineralização. A principal atividade ígnea foi considerada anterior à Série Camaquã (Tab. 3) e, consequentemente, os depósitos nela encaixados não poderiam derivar-se diretamente dos andesitos. Segundo suas conclusões houve:

1) duas fases distintas de mineralização, uma relacionada e outra posterior à intrusão dos granitos (Caçapava, Lavras e Ramada);

2) uma só fase de mineralização derivada do magma granítico, com diferenciação muito tardia das soluções hidrotermais, após res friamento e erosão da parte superior dos "stocks" que forneceram material para a Série Camaquã; 
3) origem singenética dos depósitos.

Goñi (1961) estudou as jazidas metalíferas nas áreas de Volta Grande e Vista Alegre (não representadas no mapa regional). Considerou o granito Lavras responsável pelas mineralizaçōes de $\mathrm{Cu}, \mathrm{Au}, \mathrm{Pb}, \mathrm{Fe}$ e Ag nos andesitos, nas rochas da Série Camaquã e no próprio Granito Lavras.

Ribeiro et al (1966 págs. 153, 173 e 174), após trabalhos de campo detalhados, elaboraram nova coluna geológica regional (Tab. 3), dis cutindo, também,a origem da mineralizaçāo no Polígono. Esses auto res concluiram que:

1) as rochas andesíticas foram responsáveis pela mineralização de cobre na área, intimamente relacionada aos movimentos ao longo das zonas de falhas mais antigas;

2) todos os andesitos relacionados com a mineralização cuprífera pertencem à Formação Crespos ('Tab. 3);

3) as mineralizações existentes em riólitos, mais jovens que a Formação Crespos, podem estar vinculadas à soluçōes tardias de origem vulcânica, que concentraram cobre de rochas andesí ticas já consolidadas.

Em face do mapeamento geológico de detalhe, à escala 1:50.000, efe tuado na Folha de Bom Jardim, Ribeiro (1968) modificou alguns dos conceitos emitidos anteriormente. Concluiu que a origem imediata do cobre, para as ocorrências da Folha de Bom Jardim, pode ter sido de diversas fontes, tendo havido recorrência de mineralização para sua remobilização. Agrupou as ocorrências nos tipos mesotermal e tele termal, sendo o uso do último termo desvinculado do significado usual da literatura. Quanto à origem das ocorrências do tipo teletermal, o autor admitiu que eventos tectônicos poderiam ter ativado águas circu lantes ou das próprias rochas encaixantes, de modo que, a temperaturas favoráveis, elas pudessem dissolver compostos metálicos presentes nas 
rochas ígneas, sedimentares ou metamórficas. Para corroborar essa hipótese, o autor determinou concentraçöes de Cu nas rochas associa das a êsse tipo de mineralização, na área da Folka de Bom Jardim. Concluiu, então, que os conteúdos de Cu nessas rochas seriarn sufi. cientes para produzir as concentraçōes observadas nas ocorrências.

De um modo geral observa-se que os pesquisadores do Polígono Cu prífero Riograndense, na sua quase totalidade, se preocuparam em elaborar um esquema geral, que explicasse a origem da mineralização em toda a área. Em alguns casos, Goñi (1961) e Ribeiro (1968), as interpretações se referem a um único distrito ou área restrita.

Fstudos mais recentes, no entanto, demonstram que as assembléias minerais, nas principais jaridas e ocorrências do Polígono, podem ser discordantes entre si sugerindo existência de subzonas, na mesma província metalogenética. Desta maneira, a origem dos minerais em cada subzona deveria ser analisada independentemente, à luz de rela çöes de campo, mineralogia e, além de tudo, do comportamento geo químico dos principais elementos.

Tendo em vista que os estudos aqui apresentados se referem exclusi vamente ao Distrito Cuprífero de Camaquã, não serão efetuadas con siderações genéticas regionais. Além disso, os dados geoquímicos disponíveis, aliados às observaçōes de caráter mineralógico e tectô nico permitem apenas conclusões provisórias quanto à mineralização primária no distrito.

A evolução magmática e tectônica do núcleo de Caçapava -. Lavaras, esboçada por Ribeiro e Carraro (1972) permite depreender que a re giāo foi afetada por uma fase magmática granítica no Pré-Cambriano Superior, representada pelos "stocks" graníticos de Caçapava, Lavras, e outros corpos menores. Além desta fase ígnea granítica, houve ati vidade vulcânica, também de idade pré-cambriana, e duas outras pos teriores, referidas ao Paleozóico Inferior. As evidências de campo, segundo esses autores (1972), indicam também que os granitos Caçapa va e Lavras são intrusivos nos sedimentos do Grupo Bom Jardim. 
Pelas datações de Minioli (1972), conclue-se que os granitos e o vul canismo andesítico são mais antigos do que $590 \mathrm{~m}$. a., não havendo indicações sobre suas idades absolutas. A evolução magmática local, no entanto, deixa crer que tanto as intrusivas graníticas quanto as rochas vulcânicas pertencem a um mesmo ciclo magmático, sendo prováveis produtos diferenciados de um mesmo magma. Acredita-se que a mineralização no Distrito de Camaquã esteja relacionada a este ciclo e estreitamente vinculada a um magmatismo de natureza inter mediária.

A mobilização e movimentação, em profundidade, das soluções mine ralizantes, seria possível graças à integração da atividade ígnea e das fraturas profundas, que atingem o embasamento cristalino subja cente. Estas fraturas constituiriam os canais primários das soluçōes hidrotermais, sendo representadas, na área da Mina, pelos grandes falhamentos de direção NE e suas falhas normais NW, subsidiárias e portadoras de minério, todos formados ao final da deposição do Grupo Bom Jardim.

Os dados geoquímicos sobre a distribuição dos elementos traço, permi tem nptar. pelo menos em caráter preliminar, por uma origem hidro termal plutógena para as piritas da Mina de Camaquã. As razões Co: $\mathrm{Ni}$, assim como a ausência de minerais de $\mathrm{Pb}$ e $\mathrm{Zn}$ no minério, levam à conclusão de que existe uma associação genética muito íntima entre o magmatismo de caráter intermediário e a deposição do minério.

A distribuição de $\mathrm{Cu}, \mathrm{Co}, \mathrm{Zn}$ e $\mathrm{Pb}$ em concentrados de minério e rochas ígneas intermediárias regionais foram estudadas em diagramas triangu lares, segundo Kilburn (1960). A similaridade de razões e a tendência desses elementos também sugerem ụma vinculação do minério às rochas intermediárias.

Grande parte do Fe necessário à formação do minério pode ser originá rio das próprias rochas sedimentares encaixantes, atrayessadas pelas soluções. No Arenito Superior, os óxidos de ferro chegam a atingir proporções de 4 a $8 \%$ do volume da rocha. 
A mineralização hematítica e a alteração clorítica associada, observa das na Mina Uruguai, indicam a presença de soluções ricas em Fe e Mg. Parece lógico afirmar que o Fe tenha sido mobilizado pelas solu ções hidrotermais da terceira fase de mineralização. A quantidade de Mg necessária à for mação das cloritas tem origem duvidosa, pois tanto poderia estar relacionada às encaixantes, como a alguma rocha de caráter mais fêmico, embora estas näo ocorram em superfície.

Os estudos geoquímicos efetuados não permitem soluçäo definitiva para a disputa sobre a origem da mineralização, seja ela hidrotermal, a partir de rochas ígneas, ou por remobilização de elementos metálicos singenéticos, por manifestações vulcânicas e magmáticas que afetaram a região de Caçapava - Lavras. Entretanto algumas considerações devem ser feitas.

Em razão do próprio tipo de depósito, parece razoável admitir uma origem magmatógena, embora não seja possível indicar o mais pro vável tipo de rocha ígnea que teria dado origem às soluçōes hidroter mais. Também o comportamento geoquímico de alguns elementos fornece algumas indicaçöes nesse sentido.

As irregularidades na distribuição de Co e $\mathrm{Ni}$ em piritas, indica que a mineralização é hipógena, provavelmente originada de uma rocha mag mática de composição intermediária.

Sendo hipógena, é óbvio que nenhum dos derrames andesíticos, no nível atual de erosão, pode ser responsabilizado diretamente pela for mação das soluções hidrotermais. Entretanto, não pode ser excluída a hipótese da existência de magma intermediário, consolidado em pro fundidade, em cujo estágio final de solidificação terian se formado as soluções hidrotermais. 
Aparentemente, as observaçōes derivadas da razão Co: $\mathrm{Ni}$, ou da irregularidade de Co: Ni em piritas, nāo são por si sós gargumentos suficientes para diagnosticar o ambiente de deposição do minério primário. As possibilidades de contaminação dos fluídos em seu tra jeto para a superfície, devido à dissolução e substituição operadas nas paredes das rochas percoladas, devem ser levadas em considera ção, como apontaram Hawley e Nichol (1961). Entretanto, é possível que os dados geoquímicos possam ser aplicados e complementados com determinaçöes de outros parâmetros, de maneira a permitir um quadro interpretativo mais completo. 
1. A produçăo total do Distrito Cuprífero de Camaquã, até à presente data, pode ser avaliada em cêrca de 25.000 tone ladas de $\mathrm{Cu}$. Esta produção proveio na maior parte, das minas S. Luiz e Uruguai.

2. A reserva de minério inferido e previsto até aos níveis 1.200 pés das minas S. Luiz e Uruguai é de cêrca de 17 milhões de toneladas. Os teores em $\mathrm{Cu}$ variam entre 1,0 e $1,5 \%$.

3. A área da Mina Camaquã foi submetida a um esforço de compressão local. O esforço de gravidade $\left(\sigma_{1}\right)$ foi vertical. A componente horizontal $\left(\sigma_{3}\right)$ possue direção NE/SW. A componente compressional $\left(\sigma_{2}\right)$ tem direção NW/SE.

4. Há predominância de 2 classes de falhas normais esçalona das, transversais ou oblíquas às direções da camadas locais:

N $50 \mathrm{~W}-70 \mathrm{SW}$
Classe 1
N $60 \mathrm{~W}-60 \mathrm{NE}$

Classe 2 $68 \mathrm{NE}-51 \mathrm{NE}$
$\mathrm{N} 20 \mathrm{~W}-81 \mathrm{NE}$

Estas falhas são resultantes de esforços de segunda ordem com direção predominante NW/SE e sentido SE/NW.

5. As falhas principais de direção NW são acompanhadas por brechas e juntas penadas obliquas ou subverticais que resulta. ram de esforços de segunda ordem. 
6. Todos os filoes da Mina de Camaquã seguem as falhas normais NW do Sistema Irapuá. Boa parte, também, da mineralizaçáo primária está contida em juntas penadas e brechas associadas às falhas principais.

7. Os filões de minério mais possantes estão localizados nas minas S. Luiz e Uruguai. Ocupam as fraturas NW. Os mer gulhos dos veios são para quadrantes opostos, sendo NE na Mina S. Luiz e SW na Mina Uruguai.

8. Os depósitos filonares se localizam em arenitos e conglome rados dos Membros Mangueirão e Vargas.

As concentraçōes de minério, de grande porte, se localizam no Conglomerado Vargas. A mineralização sulfetada nos arenitos é escassa em relação aos conglomerados onde é abundante.

9. Os filóes destas duas minas, quando agrupados, definem dois grandes corpos de minério que possuem caimentos para qua drantes opostos, NE na Mina S. Luiz e SW na Mina Uruguai.

10. Os tipos de controles de mineralização no distrito são: estru turais, estratigráficos e litológicos.

11. Os controles estruturais mais importantes säo: intersecções de fraturas, estruturas penadas, falhas menores associadas a falhas maiores, caracteres físicos das rochas encaixantes, irregularidades dos planos de falhas, movimento intra-minério e zonas de brechas. 
12. As grandes concentraçōes de minério em arenito, observa das nos contatos Arenito Inferior - Conglomerado Inferior, devem ser relacionados a deflexöes das falhas principais ao atravessarem rochas com características físico-mecâ nicas dissimilares, provocando frraturamento e brechamen to intenso.

13. Os processos supérgenos foram responsáveis pela acumula ção de minério oxidado e enriquecido à superfície e na zona de enriquecimento.

14. A sequência paragenética estabelecida caracteriza a existên cia de quatro fases de mineralização no distrito : fase prin cipal da pirita, fase principal da calcopirita, fase da hema tita e fase final.

15. Foram caracterizados três períodos de alteração hidrotermal na seguinte ordem; caolinização e sericitização; silicificação associada a mineralização sulfetada e cloritização acompanha da de mineralização hematítica.

16. Co e Ni são os elementos que preferencialmente se concentram na pirita e calcopirita.

17. As concentrações de Co e Ni são irregulares em pirita e cal copirita e não há nenhuma distribuição sistemática desses elementos, em profundidade.

18. As razōes Co/Ni em piritas e calcopiritas são $>1$.

19. As irregularidades de distribuição de Co e Ni em piritas indi cam que a mineralização primária é hidrotermal plutógena. 
20. As razóes $\mathrm{Co} / \mathrm{Ni}>1$ e a ausência de minerais de $\mathrm{Pb}$ e $\mathrm{Zn}$ no minério, indicam uma vinculação da mineralização a rocha magmática de composição intermediária.

21. Não se exclui a possibilidade de formaçāo de soluções mine ralizantes no estádio final de consolidação de magma inter mediário em profundidade.

22. Os estudos efetuados e os dados disponíveis não permitem solucionar em definitivo o problema da origem da minerali zação. Parece razoável admitir uma origem profunda a partir de rocha magmática de composição intermediária. 


\section{XIX - AGRADECIMENTOS}

Os melhores agradecimentos são endereçados às seguintes entidades: Companhia Brasileira do Cobre, na pessoa do Sr. F. Pignatari, sem cuja valiosa ajuda não seria possível a execução deste trabalho; Fundação de Amparo à Pesquisa do Estado de São Paulo, que conce deu bolsa de doutoramento ao autor; Outokumpu Mining Company, por intermédio do Dr. T. Hukli, pelas análises químicas efetuadas por micro-sonda eletronica; Departamento de Minas da Escola Poli técnica da USP, pelas facilidades de utilização de equipamentos do Laboratório de Concentração de Minerais. Ao Prof. Dr. Geraldo C. Melcher, orientador dos trabalhos, o reconhecimento do autor pelo apoio e incentivo que sempre the dispensou. Agradecimentos especiais são devidos aos colegas: U. G. Cordani, K. Kawashita e R. Torquato pelas determinações isotópicas: R. Hypólito e M. Borenholc pela execução de análises químicas; Dr. E.F.Grâ vonski e Eng. L. Cornuth, da Mina de Camaquã pela enorme ajuda dispensada.

E dever também registrar a valiosa colaboração dos colegas: Dr. Y. Hasui e geólogo G. R. Sadowsky pela ajuda e sugestões concernentes à Geologia Estrutural; Dr. R. Ellert pelo auxílio e discussões referen tes a microscopia de líninérios; Dr.H. Born pela revisão do texto; $S$ r. L. Ojima pelas determinações de Raios X; Dr. M. A. Farias de Oliveira pelas determinações ópticas e Geólogo O. Mayeama pela ajuda desinteressada. Aos colegas do Departamento de Mineralogia e Petrolo gia, meus agradecimentos pela cooperação na fase final do trabalho. A Srta. Vanir de Almeida agradecemos o trabalho de datilografia. 
ALIMEIDA, F.F. - 1966 - Origem e evolução da plataforma Brași leira. Sedegeo, 2: 46 - 89 - Idem 1967 - Div. Geol. Miner. D. N. P.M.Bol. $241: 36$ p.

ANDERSON, E. M. - 1951 - The dynamics of gaulting and dyke formation with applications to Britain. Oliver and Boyd Pub., Edinburgh and l.ondon.

AMARAL, G., CORDANI, U. G. , KAWASHITA, K., REYNOLDS, J.H. 1966 - Potassium - argon dates of basaltic rocks from Southern Brazil. Geochim et Cosmochim. Acta, 30, pp 159 a 189 .

BETTENCOURT, J.S. e DAMASCENO, E.C. - 1969 - Mapeamento Geológico dos Níveis 400 e 500 das Minas Uruguai e S. LuizDistrito Cuprífero de Camaquä. R. G,S. - (Arquivos da C. B. C.).

BETTENCOURT, J.S. e CORNUTH, L. - 1971 - Reservas da Mina de Camaquã. Arquivos da C.B.C., São Paulo.

CAMBELL, B. e JARKOVSKY, J. - 1967 - Geochemie der Pyrite einiger Lagerstalten der Tschechos-lowakei. VSAV, Bra tislava.

CAMBELL, B. e JARKOVSKY, J. - 1968 - Geochemistry of Nickel: and Cobalt in Pyrrhotines of different genetic types - XXIII International Geological Congress - vol. 6 -pg 169 - 183. - 1969 - Geochemistry of Pyrrhotite of various genetic types. Komensky University Bratislava - Czechoslovakia. 
CARVAlHO, P.F., de - 1932 - Reconhecimento Geológico no Esta do do Rio Grande do Sul, Brasil. Serv. Geol. Mineralógico, Bol, no 66, Rio de Janeiro.

CHAYES, F. - 1949 - A simple point - counter for thin - section analyses - Amer. Mineral., 134, p. 1 .

COMISSÃO MISTA DOS METAAIS NÄO FERROSOS - 1959 - Mapa Geo lógico da Mina do Camaquä (Arquivos da C. B. C.).

COSTA Fo, J.H. - 1944 - Prospecção da Mina de Cobre do Cama quã no R.G.S. - Div. Fom. Prod. Min. - Bol. no 59, p. 11 - 85 - Rio de Janeiro.

S.P. DAS GUPTA, P.R. SEN GUPTA and M. V. N. MURTHY "Nature and significance of wall rock alterations in some hydrothermal ore - deposits of India" Economic Geology, vol. $60,1965, \mathrm{pg} .1702 / 1708$.

ELLERT, N. - 1971 - Aplicação do método elétro-magnético indu tivo na prospecção de minério de cobre. Tese de livre-do cência U.S.P.

FLEISCHER, M., - 1955 - Minor elements in some sulfide minerals. Econ. Geol., 50 th, Ann. Vol. $970-1024$.

GAVELIN, S. e GABRIELSON, O. , - 1947 - Spectrochemical investi gations of sulfide minerals from the ores of the Skellefte district. Sveriges Geol. Unders. C- 491.

GAVRONSKI, E.F. - 1965 - Prospecção e Programas de Pesquisa de Cobre no R. G.S. - 1a. Semana de Debates Geológicos do Centro Acadêmico dos Estudantes de Geologia da UFRGS - SEDEGEO - p 72-86. 
GAVRONSKI, E.F. - 1971 - Elementos informativos sôbre a pro vincia metalífera no Rio Grande do Sul, em particular no que diz respeito a cobre (inédito) .

GONI, J.C., GOSO, H., ISSLER, R.S. - 1962 - Estratigrafia e Geologia Econômica do Pré-Cambriano e Eo - Paleozóico Uruguaio e Sul Riograndense - Esc. Geol. Univ. R. G.S., avulso n? 3 , Porto Alegre.

GRAHAM, R.A.F. - 1968 - Effects of diabase dike intrusion on sulfide minerals at Manitouwadge, Ontário. Canadian Journal of Earth Sciences, vol. 5, no 3, pg. 545 .

HAWLEY, J.E. - 1952 - Spectrographic studies of pyrite in some Eastern Canadian goldmines. Econ. Geol, 47, $260-304$.

HAWLEX, J.E. E NICHOL, I. - 1961 - Trace elements in pyrite, pyrrhotite and chalco- pyrite of different ores. Econ. Geol. 56, $467-487$.

KILBURN, L.C. - 1960 - Nichel, cobalt, copper, zinc, lead and sulfur contents of some north american base-metal sulfide ores. Econ. Geol. vol. 55, 1960, pp. 115-1.37

LEINZ, V. e ALMEIDA, S. C. - 1941 - Gênese da Jazida de Cobre "Camaquã" - Secr. Ind. Com. R.G.S. - DPM-RGS-Bol. no 8 - Porto Alegre.

LEINZ, V., BARBOSA, A. F. e TEIXEIRA, E.A. - 1941 - Mapa Geológico Caçapava-Lavras - DPM - Bol. no 90 - Porto Alegre.

LEONARDOS, O.H. - 1944 - Cobre no Estado do RGS - Div. Fom. Prod. Min. - Bol. no 59, parte IV, p 99 - 117 - Rio de Janeiro. 
LOFTUS HILLS, G. , e SOLOMON, M. - 1967 - Cobalt, nickel and selenium in sulfides as indicators of ore genesis. Mineralium deposita 2, 226 - 242.

LOVERING, T.S. - 1942 - The Nineral Belt of the Colorado Front Range. "Ore Deposits as Related to Structural Features" Edição N.H. Newhose. Princeton, New Jersey. pag. $79-92$.

LOVERING, T.S. e GODDARD, E.N. - 1950 - Geology and Ore Deposits of the Front Range Colorado. U,S. Geol. Survey Prof. Paper, 223.

MARTINELLT, J.A. e NOGUEIRA Fo J.V. - 1959 - Prospeção Geo química de Cobre no RS - Bol. Soc. Bras. de Geol. - v. 8, nọ 1, São Paulo.

MARTINS, A. J. e BETTENCOURT, J.S. - 1970 - Mapas Geológi cos das Zonas, Intermediária, Oscarino e Feliciano Mina Camaquã. (Arquivos da C.B.C.)

MELCHER, G.C. - 1957 - Prospeç̧ão Geoquímica em Seival e Camaquã - RS - Rel. Anual do DNPM - Rio de Janeiro.

MELCHER, G.C. - 1959 - Estado do RGS - Cobre - Div. Geol. Mi neralogia - Relatório Anual 1958, p 136-40 - Rio de Janeiro.

MELCHER, G.C. , MAU, H. JOHNSON, ROBERTSON, J.F. - 1959 Mapa geológico da Mina de Camaquã. Escala 1:1.000Arquivos da C.B.C. - São Paulo.

MELCHER, G.C. e MAU, H - 1960 - Novas Observaçōes Geológi cas na Regiāo de Caçapava do Sul - R. G.S. - Acad. Bras. de Ciências - Vol. 32 no 1 - Rio de Janeiro. 
MELCHER, G.C. - 1962 - Distríto Cuprífero de Camaquã e Seival Div. Fom. Prod. Min. - Rel. Diretoria 1958, 59, 60 Bol. 113, p 69 - 72 - RJ (Trabalhos de Grupo Brasileirom Americano).

MELFI, A.J. e ARRUDA, M.R. - 1964 - Mapeamento Geológico em Superfície das Minas do Camaquä - RS-DFPIM - Inédito Porto Alegre.

MEYER, C. e HEMLEY, J.J. - 1967 - Wall rock alteration. Em "Geochemistry of hydrotermal Ore deposits " 196 Edited by Hubert Lloyd Barnes.

MINIOLI, B. e KAWASHITA, K - 1971 - Contribuição à Estratigra fia do Eo-Paleozóico do "Escudo Riograndense". Anais do XXV Congresso da S. B. G. - vol. 1.

MOOKHER JEE, A e SUFFEL, G. G. - 1968 - Massive sulfide - late diabase relationships, Forne mine, Quebec: Genetic and chronological implications - Canadian Journal of Earth Sciences, vol. 5, n? 3 , pag. 421 .

NEWHOUSE, W.H - 1942 - Ore Deposits as Related to Structural Fratures - Ed. W.H. Newhouse - Princeton, New Jersey pag. 24 .

NILSSON C.A. - 1968 - Wall rock alteration at the Boliden Deposit, Sweden. - Econ. Geol., vol. 63, 1968, pp 472-494 。

OLIVEIRA, A.I. de - 1944 - Hiștórico da Mineração de Cobre no RGS - Div. Fom. Prod. Min. - Bol. no 59, parte I, p 1 a 10 - RJ.

PETTIJOHN, F.J. POTTER, P.E. e SIENER, J - 1972 - Sands and Sandstones. Elsevier Pub., N.Y. 
PRICE, P. - 1953 - Wall rock alteration in Northwestern Quebec. Bull. Geol. Soc. Amer. no 64, pag. 1464

RIBEIRO, M. , BOCCHI, P.R., FIGUEIREDO F' P. M. e TESSARI, R. I. 1966 - Geologia da Quadrícula de Caçapava do Sul - RGS Div. Fom. Prod. Min. - Bol. no 127, 232 p - Rio de Janeiro.

RIBEIRO, M. - 1970 - Geologia da Fôna de Bom Jardim - Rio Grande do Sul - Brasil - DNPM - D. G. M. - Bol. n? 247.

RIBEIRO IM. e CARRARO, C.C. - 1971 - Mapa Geotectônico da Região de Caçapava do Sul, RS, Brasil, XXV Congresso Brasileiro de Geologia - Bol. Esp. no 1 (Resumo das Comunicações).

RIBEIRO, M. e CARRARO, C.C. - 1971 - Geotectonic Map of the Caçapava do Sul Region RS - Brazil - Instituto de Geociências - Universidade Federal do Rio Grande do Sul Porto Alegre - Brasil.

ROBERTSON, J.F. - 1961 - Revision of the Stratigraphy and Nomenclature of Rocks Units in the Caçapava-Lavras Region, State of Rio Grande do Sul, Brazil (manuscrito inédito).

ROLAND, S. e ALIMEIDA, E.S. de - 1964 - Prospecção Geoquímica na Mina do Camaquã - DNPM - Inédito - Porto Alegre. (Executado com a cooperação da Escola de Geologia da UTRGS).

ROSENBLUM, S - 1958 - Magnetic Susceptibilities of Minerals in the Fantz Isodinamic Magnetic Separator. Amer. Miner., vol. $43-1958$ 
SALES, R.H. e MEYER, C. - 1951 - Effect of postore dike intrusion on Butte ore minerals. Econ. Geol. 46, pag $905-915$.

TEIXEIRA, E.A. - 1937 - Cobre no Rio Grande do Sul - Avulso no 22, Div. Fom. Prod. Min. Rio de Janeiro.

TEIXEIRA, E.A. - 1941 - A Mina de Cobre do Camaquä - RGS - Div. Fom. Prod. Min. - Bol. n9.49,47 p - Rio de Janeiro.

TESSARI, R.I - 1965 - Evolução Geotectônica do Escudo Sul - Riograndense - Conf. no Núcleo do Rio Grande do Sul da. Soc. Bras. de Geol. - Porto Alegre.

TRÖGER, W.E. (1956) - Optische Bestimmung der gesteinsbilden den Minerale - E. Schweizerbart'sche Verlag sbuchhandlung, Stuttgart (2a. edição). 








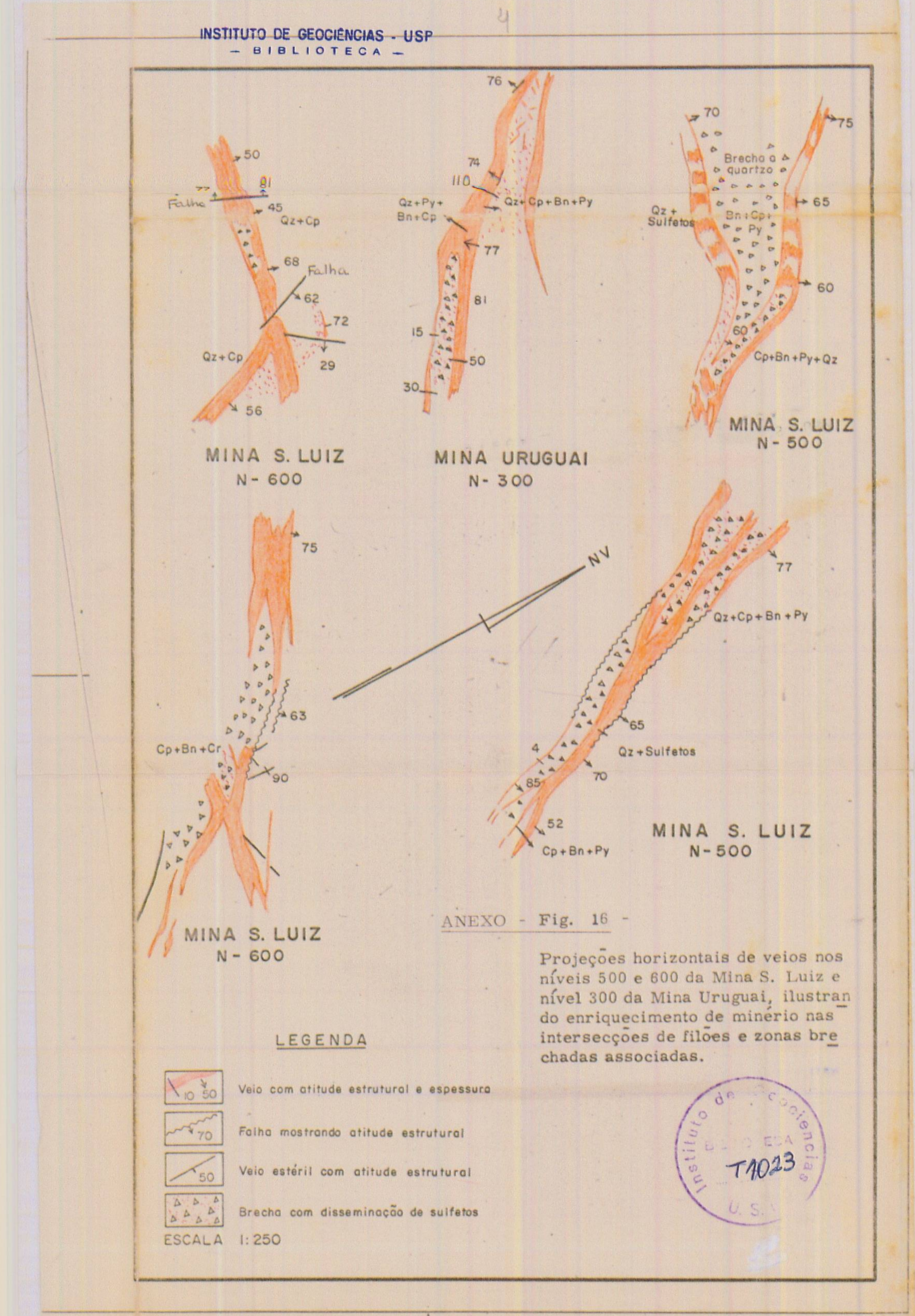









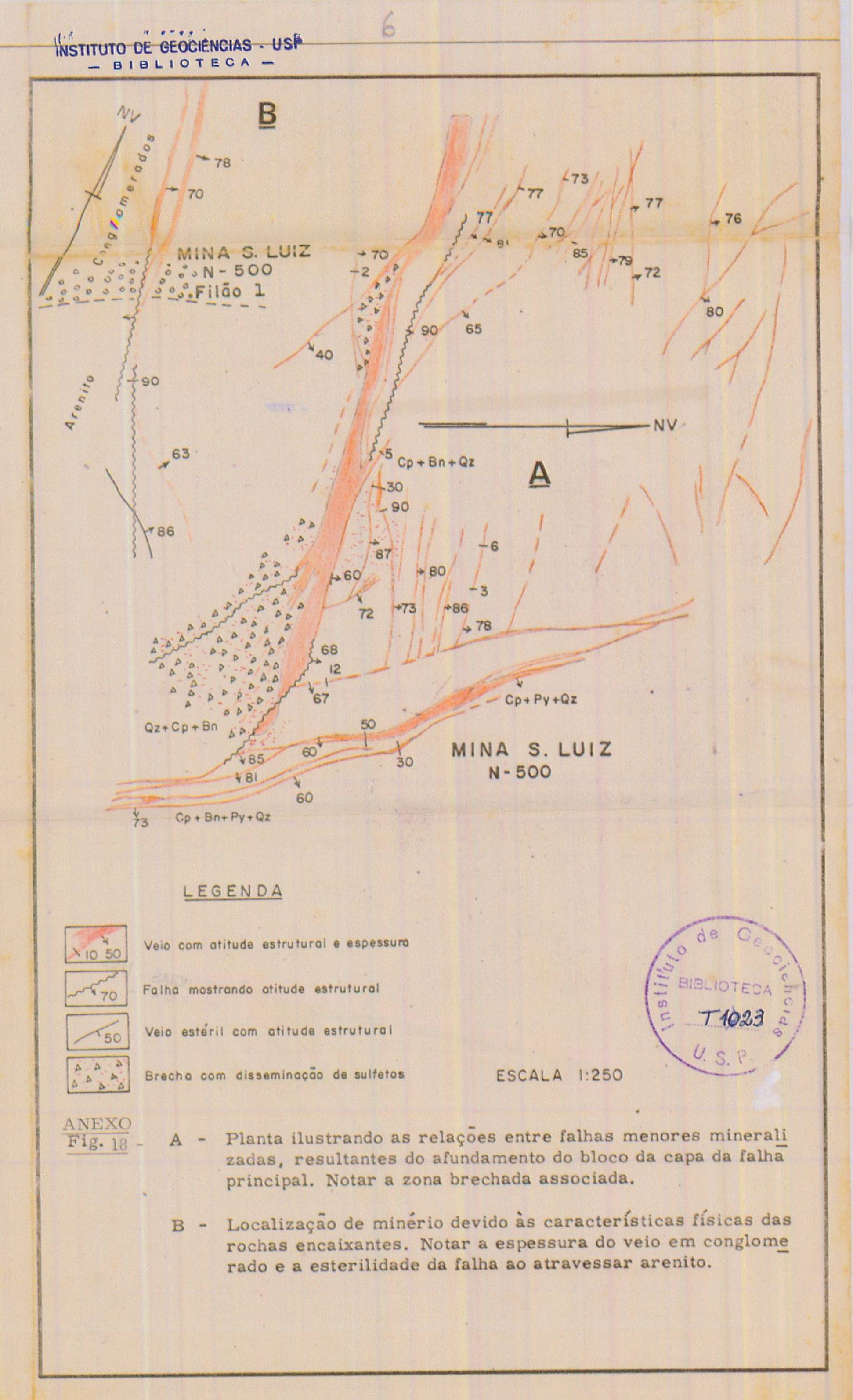




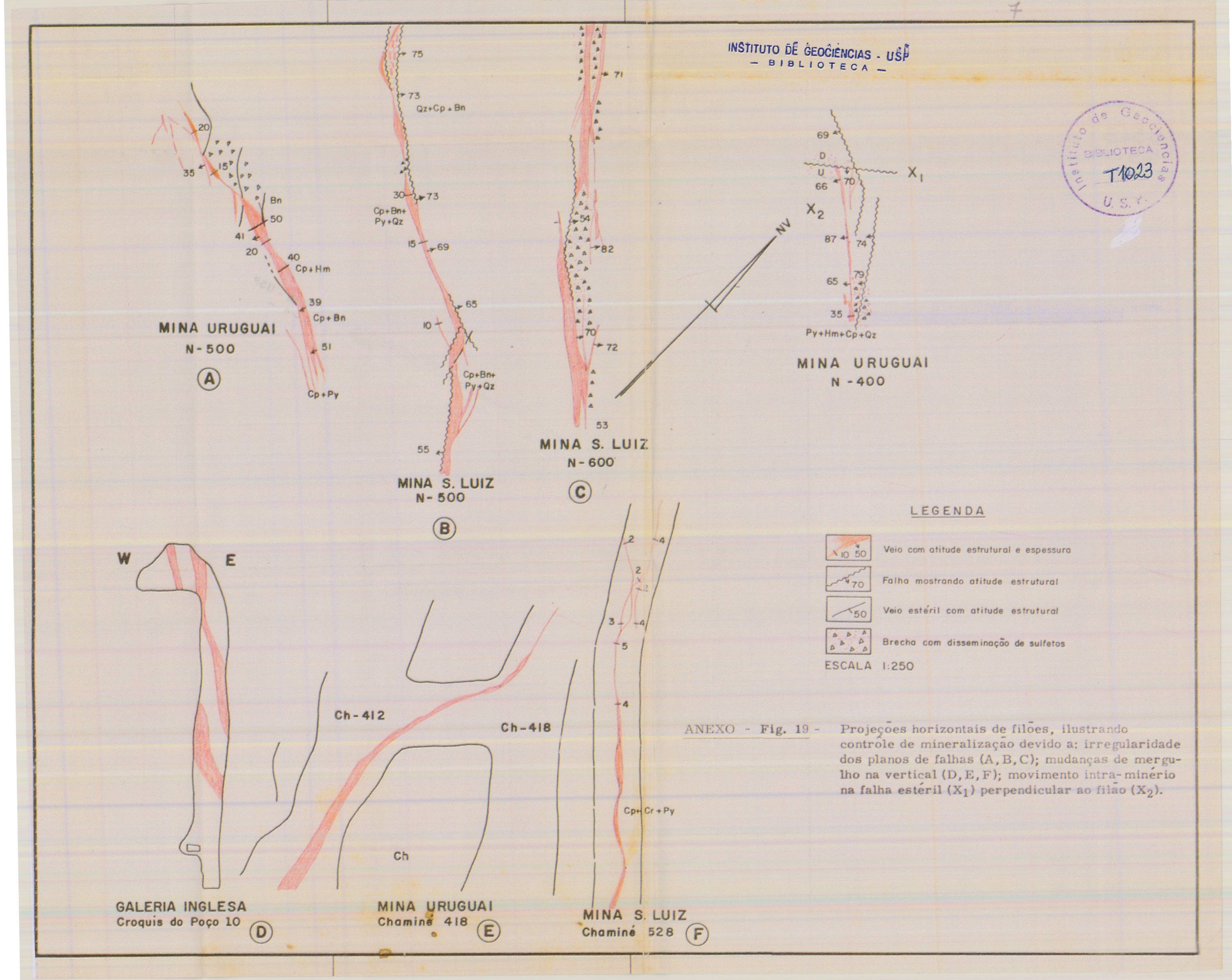




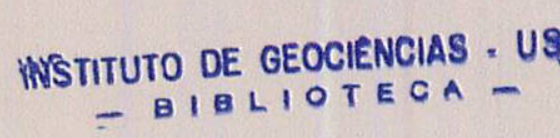

MINA SÃO LUIZ
PLANTAS DE NIVEIS

11023

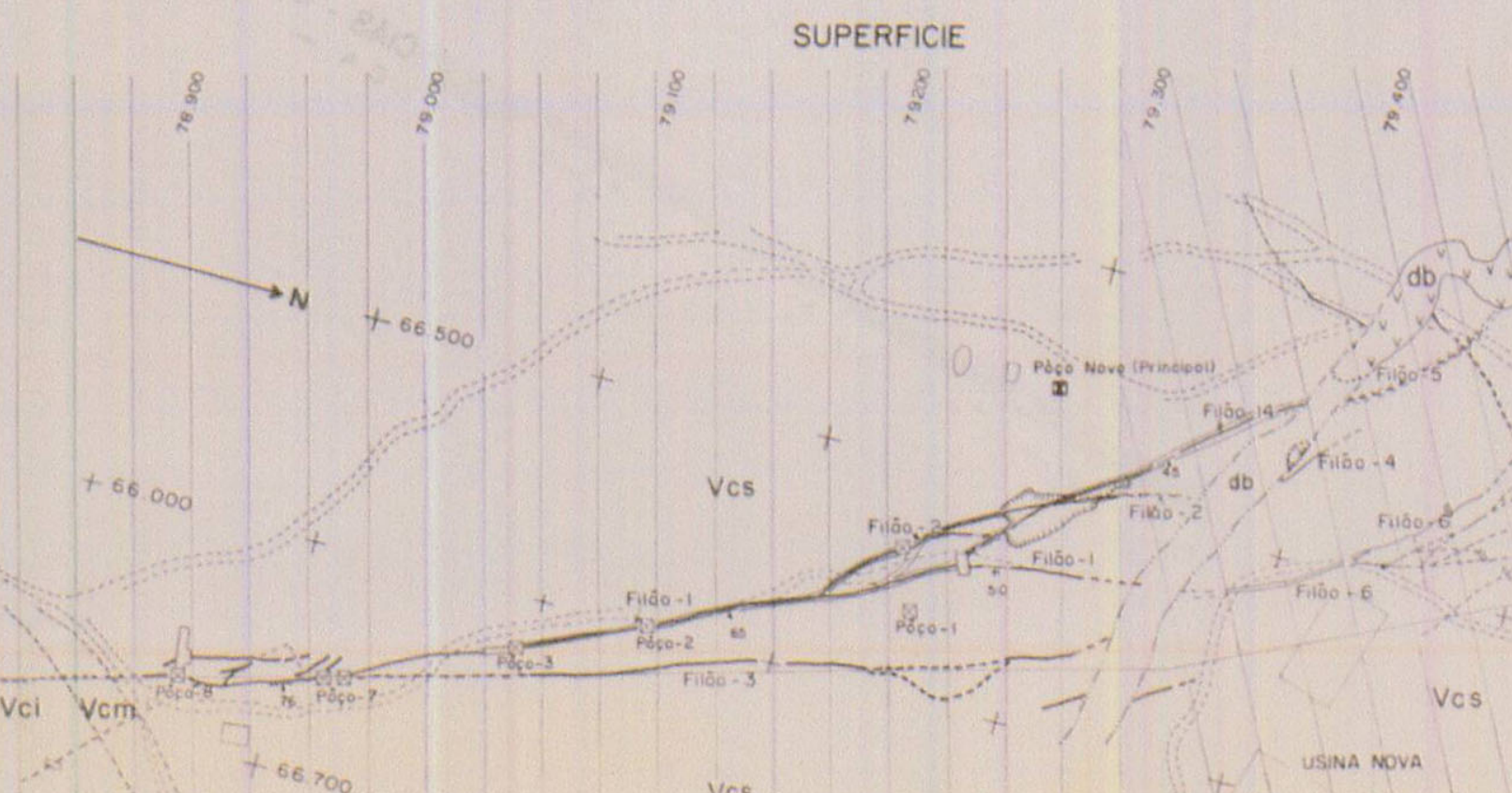

NVELL-100
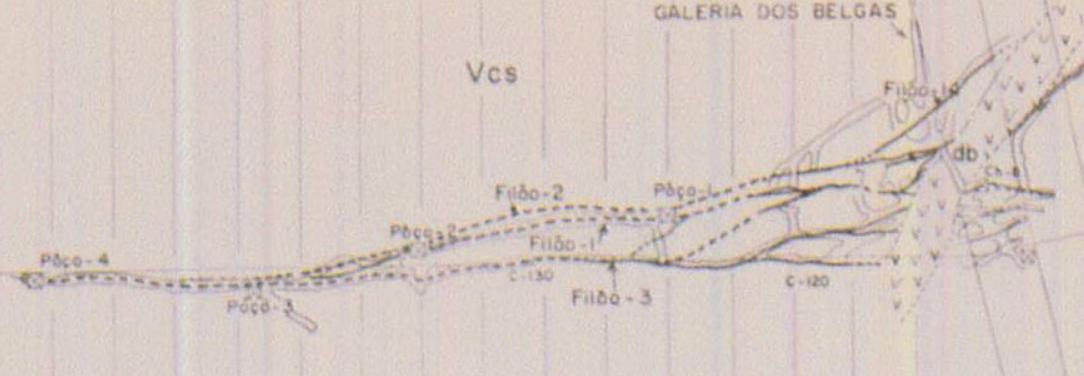

NvEL-300
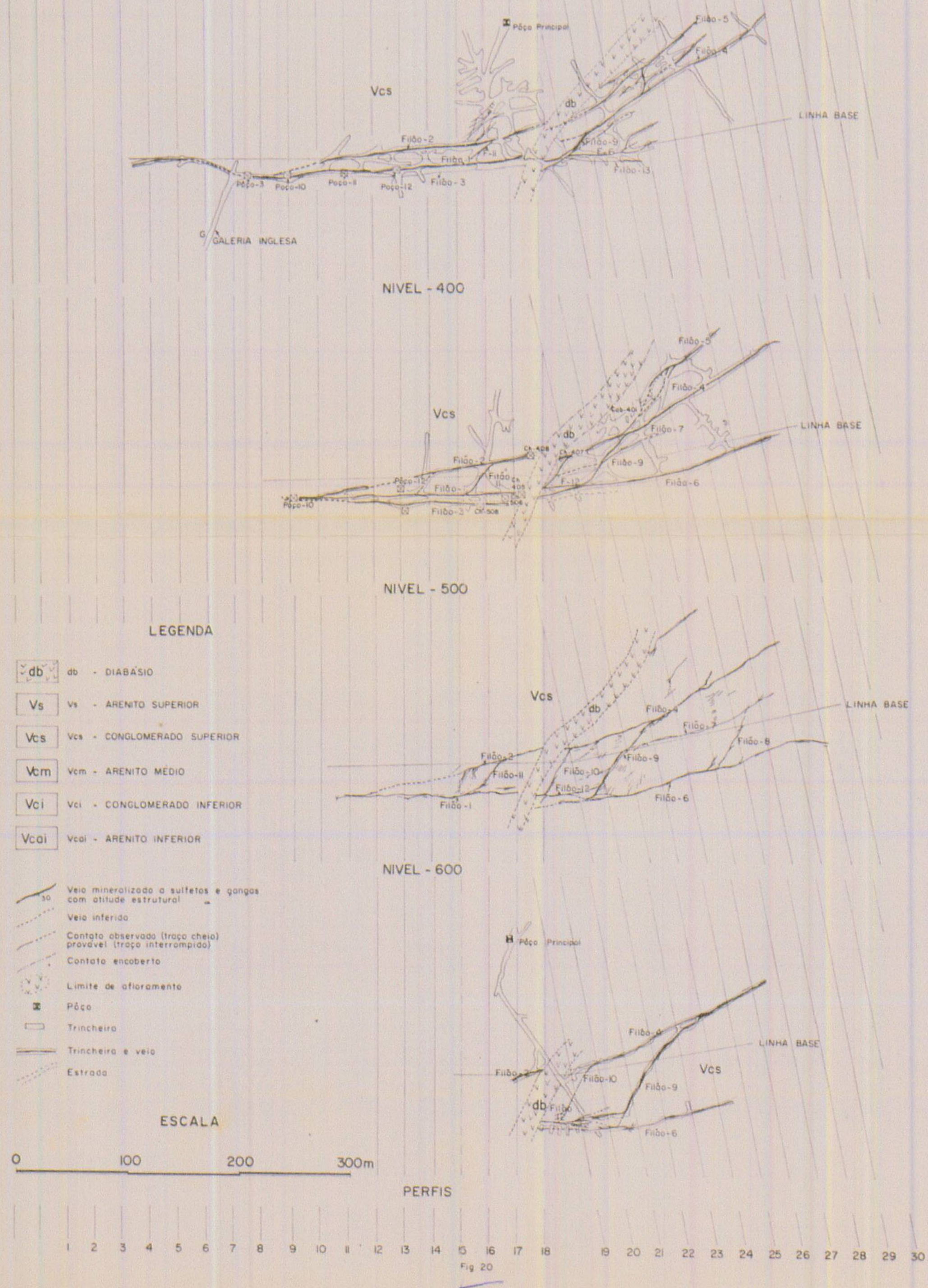


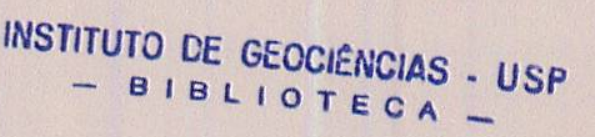

MINA URUGUAI
PLANTAS DE NIVEIS

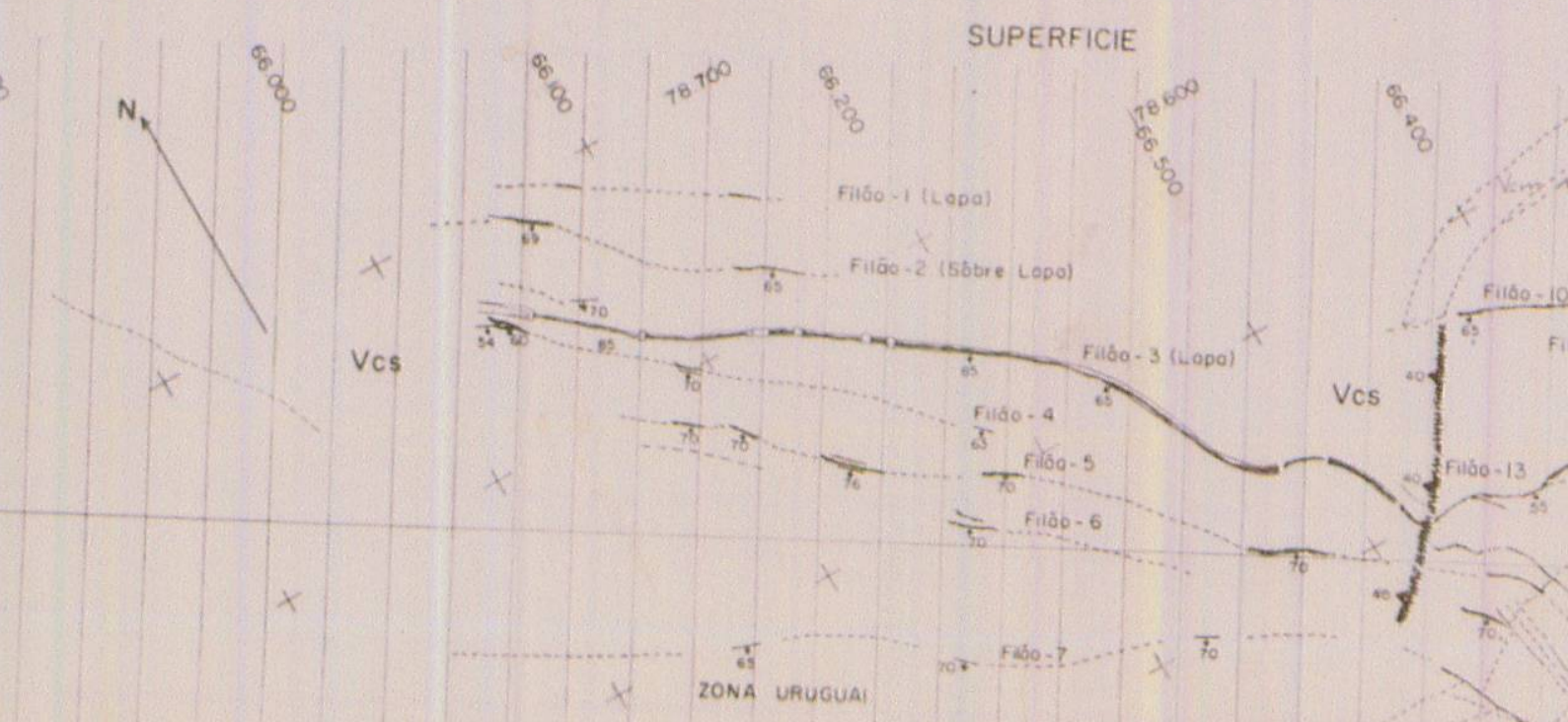

$\frac{1}{1}+2$

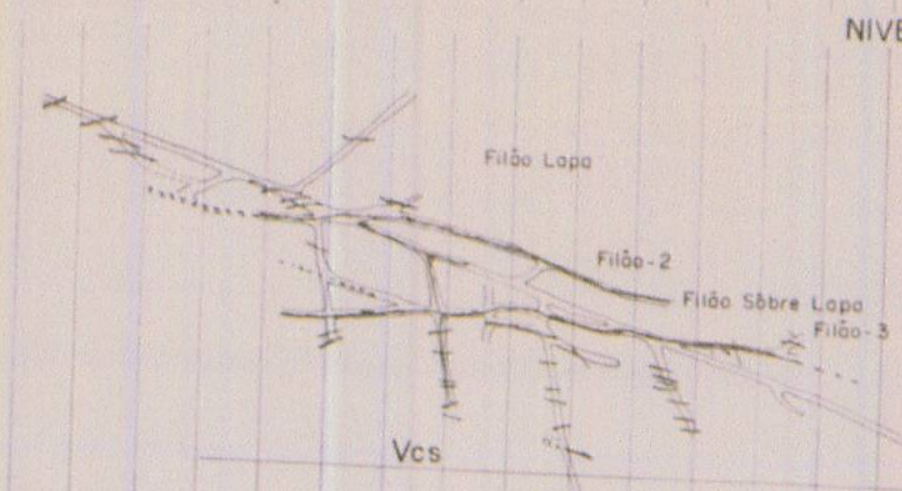

$1-2=$

$-7$

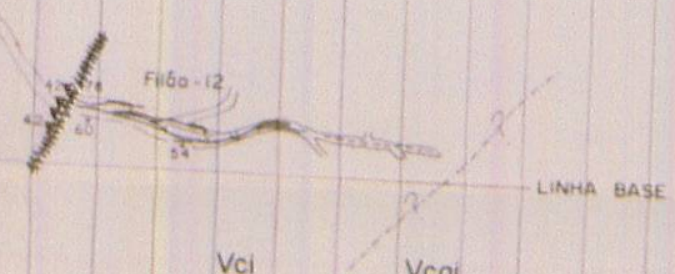

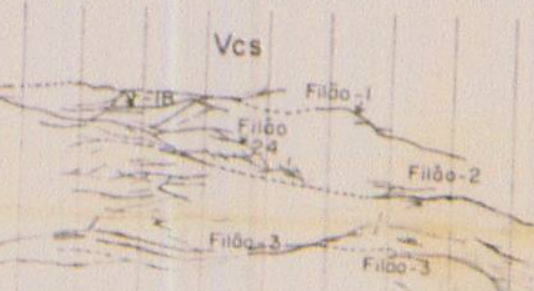

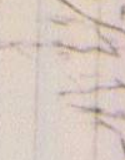

$-5=$
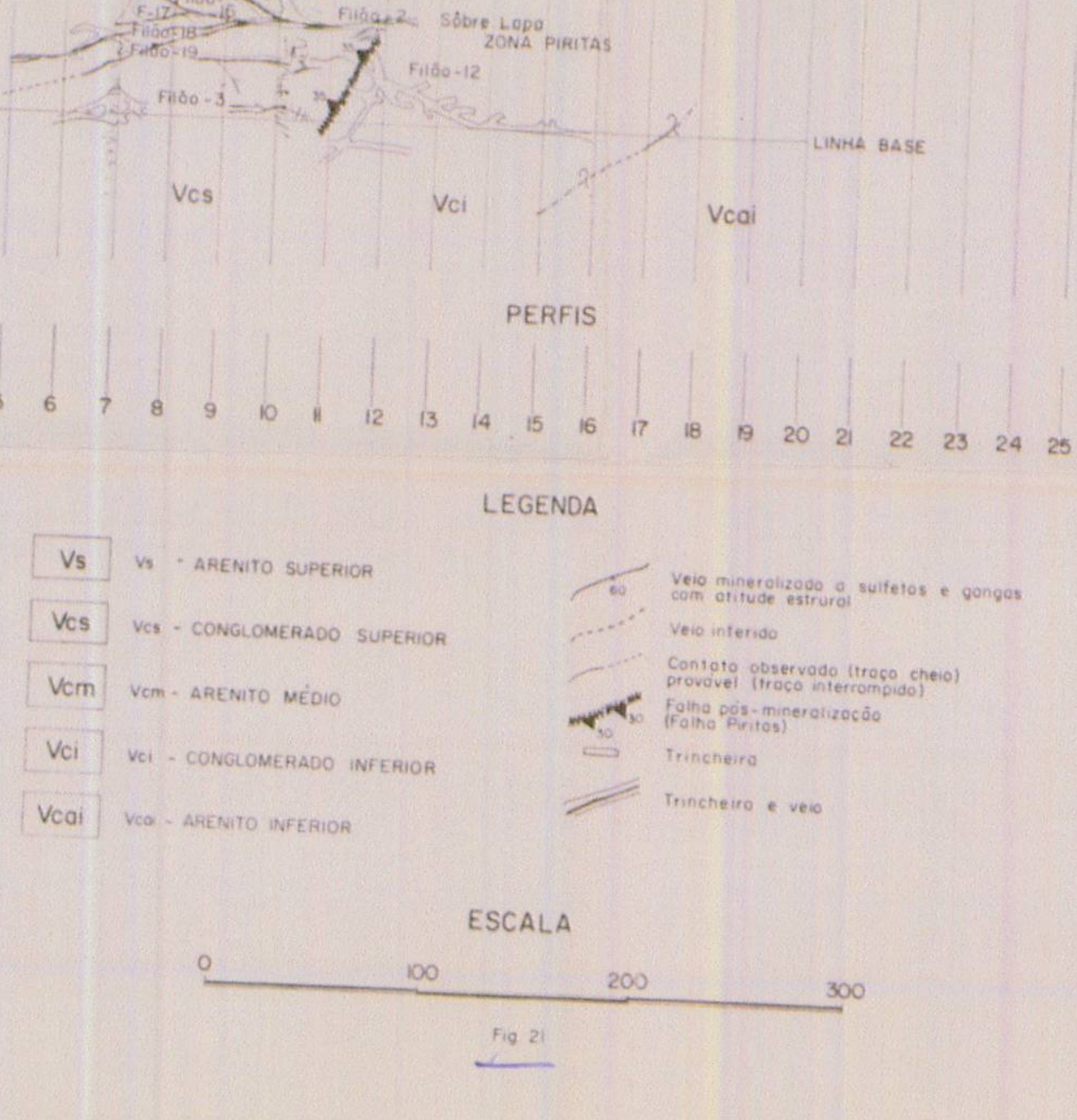


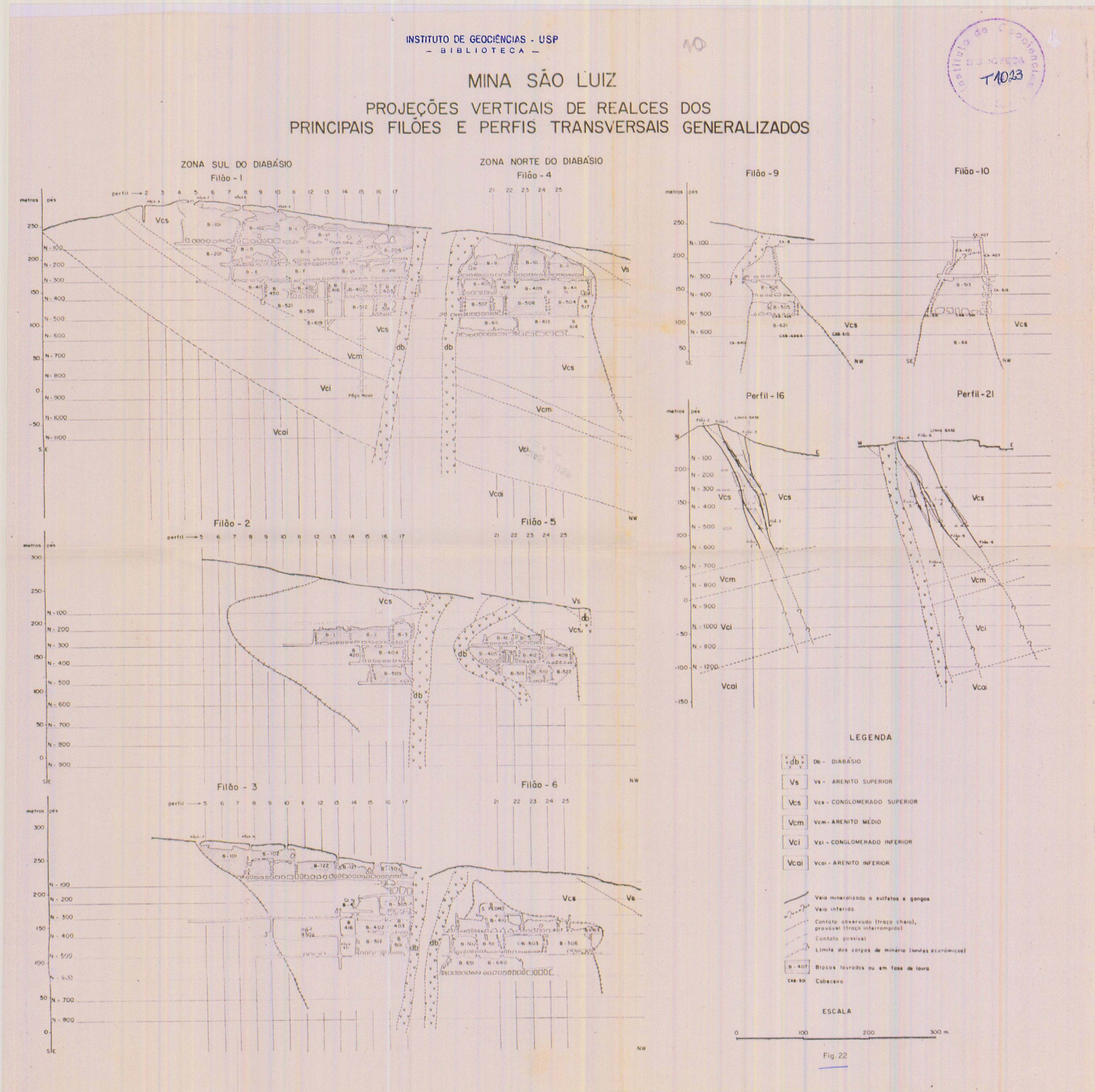



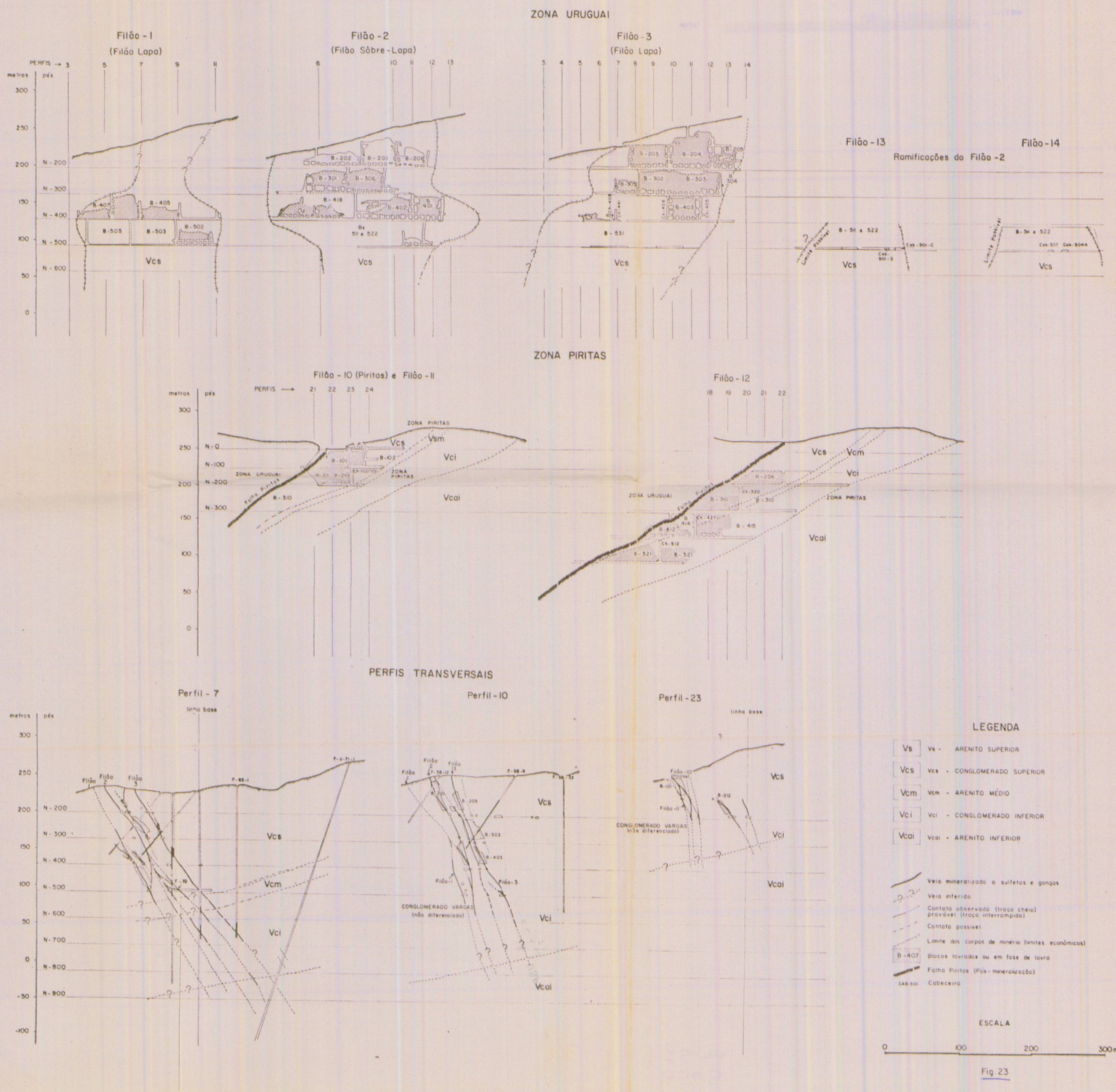